10-1994

\title{
Pharr-Reynosa International Bridge: Continued Archeological and Historical Research at El Capote Ranch Community, Hidalgo County, Texas
}

Douglas K. Boyd

Prewitt and Associates, Inc.

Andres Tijerina

Prewitt and Associates, Inc.

Karl W. Kibler

Cross Timbers Geoarcheological Services

Amy C. Earls

Prewitt and Associates, Inc.

Martha Doty Freeman

Prewitt and Associates, Inc.

Follow this and additional works at: https://scholarworks.sfasu.edu/ita

Part of the American Material Culture Commons, Archaeological Anthropology Commons, Environmental Studies Commons, Other American Studies Commons, Other Arts and Humanities Commons, Other History of Art, Architecture, and Archaeology Commons, and the United States History Commons

Tell us how this article helped you.

This Article is brought to you for free and open access by the Center for Regional Heritage Research at SFA ScholarWorks. It has been accepted for inclusion in Index of Texas Archaeology: Open Access Gray Literature from the Lone Star State by an authorized editor of SFA ScholarWorks. For more information, please contact cdsscholarworks@sfasu.edu. 


\section{Pharr-Reynosa International Bridge: Continued Archeological and Historical Research at El Capote Ranch Community, Hidalgo County, Texas}

\section{Creative Commons License}

\section{c) (1)@ $\Theta$}

This work is licensed under a Creative Commons Attribution-NonCommercial-No Derivative Works 4.0 International License. 


\title{
PHARR-REYNOSA INTERNATIONAL BRIDGE: CONTINUED ARCHEOLOGICAL AND HISTORICAL RESEARCH AT EL CAPOTE RANCH COMMUNITY, HIDALGO COUNTY, TEXAS
}

\author{
Prewltt and Associates, Inc. \\ Consulting Archeologists \\ 7701 N. Lamax, Suite 104 \\ Austin, Texas 78752 \\ (512) $459-3349$
}

by

Douglas K. Boyd

Andrés Tijerina

Karl W. Kibler

Amy C. Earls

and

Martha Doty Freeman

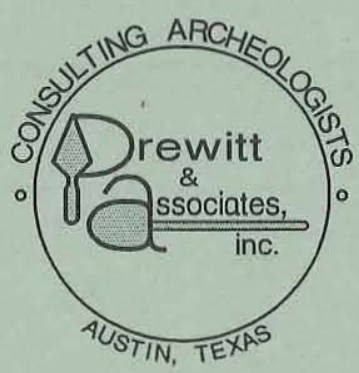




\title{
PHARR-REYNOSA INTERNATIONAL BRIDGE: CONTINUED ARCHEOLOGICAL AND HISTORICAL RESEARCH AT EL CAPOTE RANCH COMMUNITY, HIIDALGO COUNTY, TEXAS
}

\author{
by \\ Douglas K. Boyd \\ Andrés Tijerina \\ Karl W. Kibler \\ Amy C. Earls \\ and \\ Martha Doty Freeman \\ Co-Principal Investigators: Elton R. Prewitt and Martha Doty Freeman \\ REPORTS OF INVESTIGATIONS, NUMBER 97
}

Submitted to

Malcolm Pirnie, Inc.

San Antonio,Texas

by

Prewitt and Associates, Inc.

Consulting Archeologists

Austin, Texas

October 1994

TEXAS ANTIQUITIES COMMITTEE PERMIT NO. 1284 



\section{TABLE OF CONTENTS}

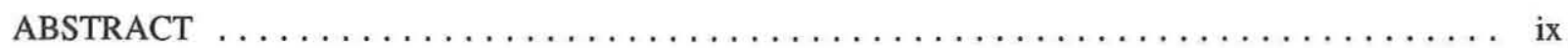

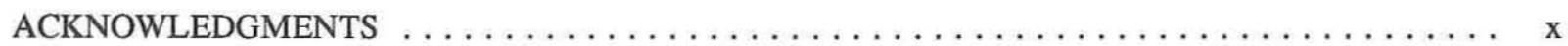

CHAPTER 1: Introduction and Environmental Background

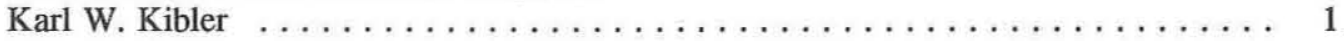

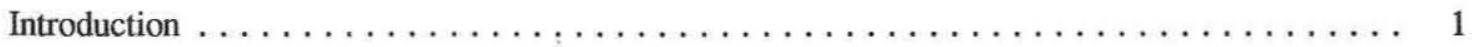

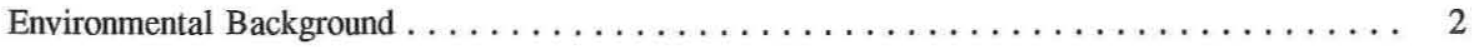

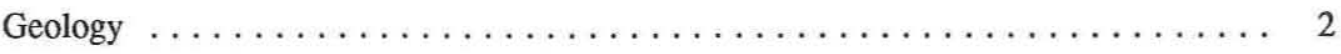

Holocene Geomorphology $\ldots \ldots \ldots \ldots \ldots \ldots \ldots \ldots \ldots \ldots \ldots \ldots \ldots \ldots \ldots$

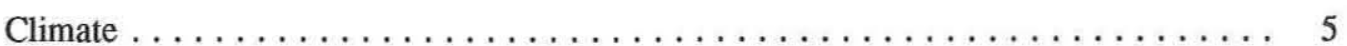

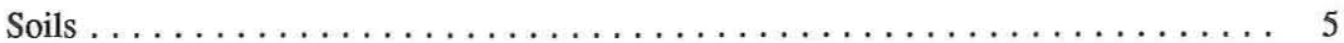

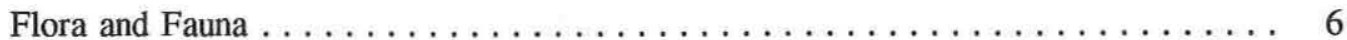

CHAPTER 2: Prehistoric and Historic Background

Andrés Tijerina and Karl W. Kibler $\ldots \ldots \ldots \ldots \ldots \ldots \ldots \ldots \ldots \ldots \ldots$

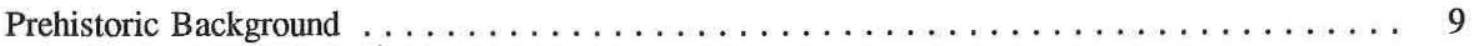

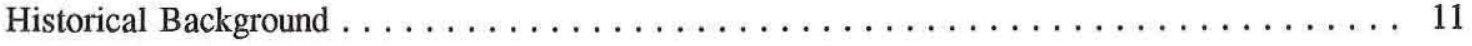

CHAPTER 3: Research Design and Methods of Investigations

Douglas K. Boyd, Karl W. Kibler, Andrés Tijerina, and Amy C. Earls . . . . . . . 21

Nature of the Cultural Resources and Research Strategy $\ldots \ldots \ldots \ldots \ldots \ldots \ldots \ldots \ldots$

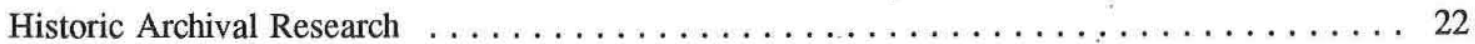

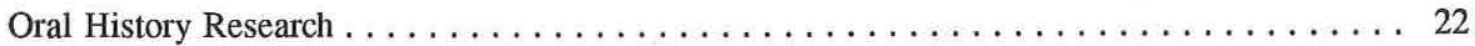

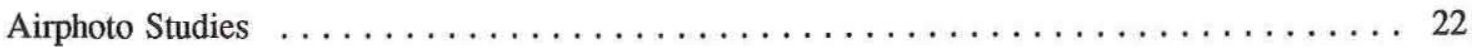

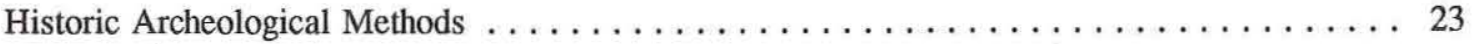

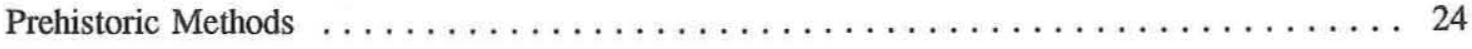

CHAPTER 4: A History of El Capote

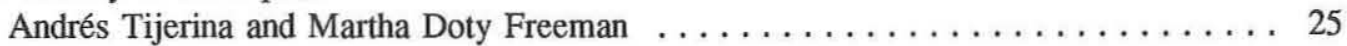

CHAPTER 5: Results of the Survey

Douglas K. Boyd, Amy C. Earls, and Andrés Tijerina . . . . . . . . . . . 39

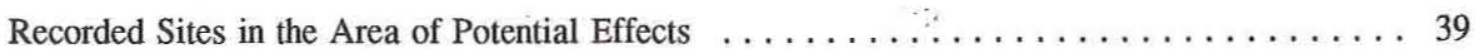

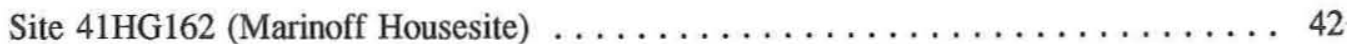

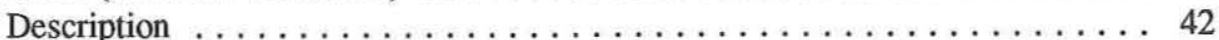

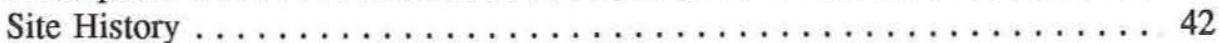

Artifacts Observed and Collected $\ldots \ldots \ldots \ldots \ldots \ldots \ldots \ldots \ldots \ldots \ldots$

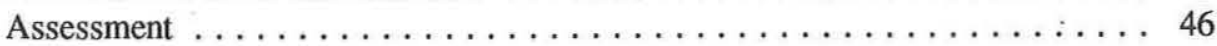

Site 41HG163 (Luca Gonzales Housesite No. 2) $\ldots \ldots \ldots \ldots \ldots \ldots \ldots \ldots . \ldots$

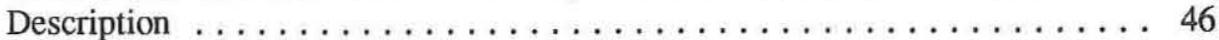

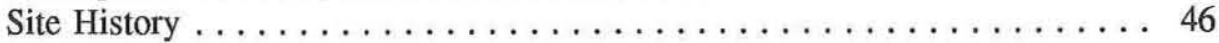

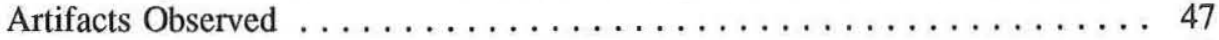

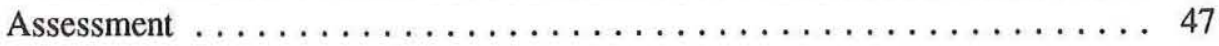


Site 41 HG164 (Joe M. Garza Housesite) $\ldots \ldots \ldots \ldots \ldots \ldots \ldots \ldots \ldots \ldots \ldots$. . . . . 47

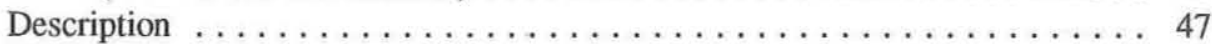

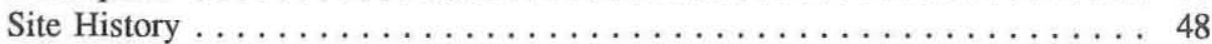

Artifacts Observed and Collected $\ldots \ldots \ldots \ldots \ldots \ldots \ldots \ldots \ldots \ldots \ldots$

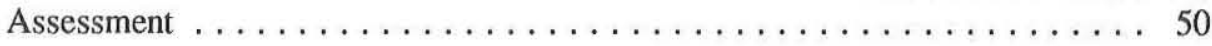

Site $41 \mathrm{HG} 165$ (Nestor and Roberto Garza Housesite) $\ldots \ldots \ldots \ldots \ldots \ldots \ldots \ldots$

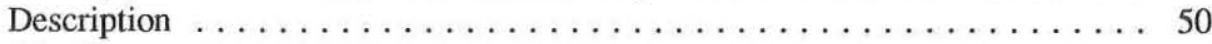

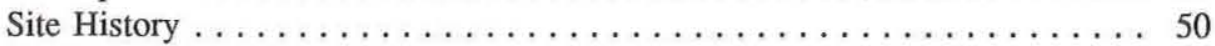

Artifacts Observed and Collected $\ldots \ldots \ldots \ldots \ldots \ldots \ldots \ldots \ldots \ldots \ldots \ldots$

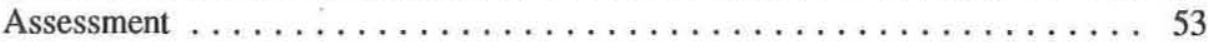

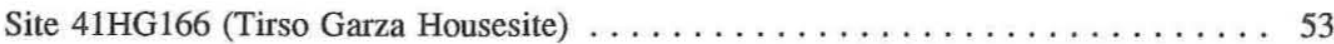

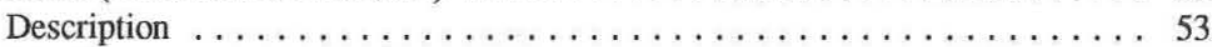

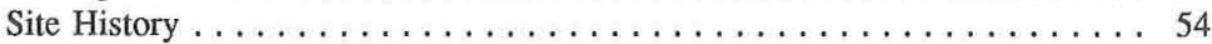

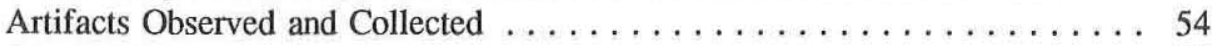

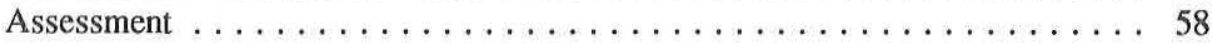

Site $41 \mathrm{HG} 167$ (Amado Lozano Housesite) $\ldots \ldots \ldots \ldots \ldots \ldots \ldots \ldots \ldots \ldots \ldots . \ldots$

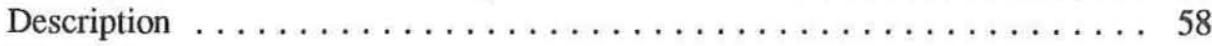

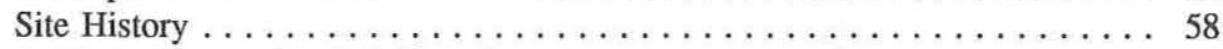

Artifacts Observed and Collected ................... 59

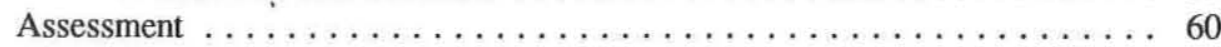

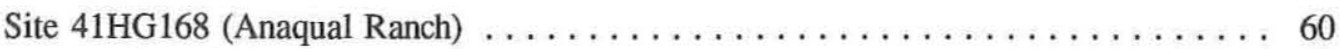

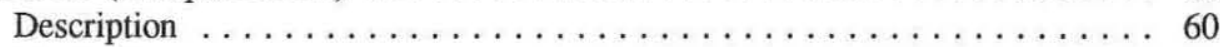

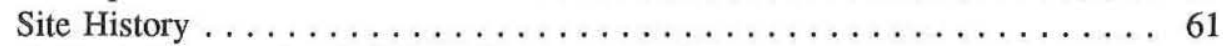

Artifacts Observed and Collected $\ldots \ldots \ldots \ldots \ldots \ldots \ldots \ldots \ldots \ldots \ldots 6$

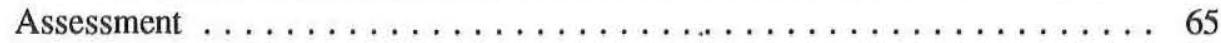

Historic Sites Adjacent to the Area of Potential Effects $\ldots \ldots \ldots \ldots \ldots \ldots \ldots \ldots \ldots$

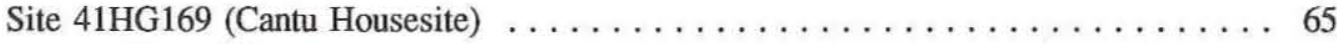

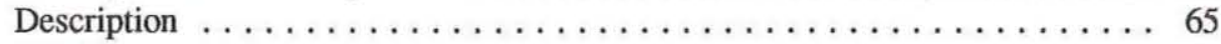

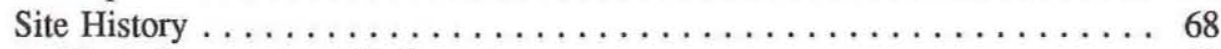

Artifacts Observed and Collected $\ldots \ldots \ldots \ldots \ldots \ldots \ldots \ldots \ldots \ldots$

Old Military $\operatorname{Road} \ldots \ldots \ldots \ldots \ldots \ldots \ldots \ldots \ldots \ldots \ldots \ldots \ldots$

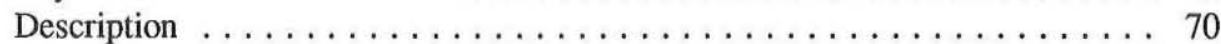

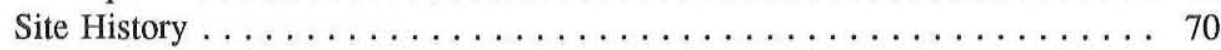

Garza Ranch No. $2 \ldots \ldots \ldots \ldots \ldots \ldots \ldots \ldots \ldots \ldots \ldots \ldots \ldots \ldots \ldots$

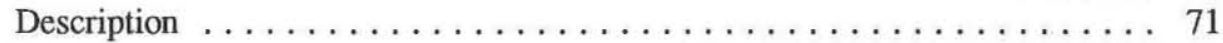

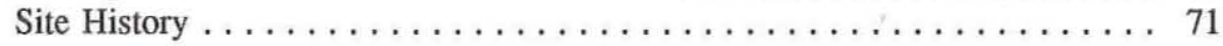

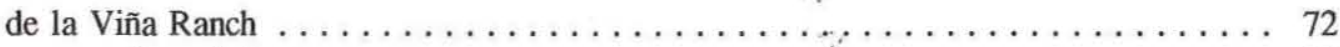

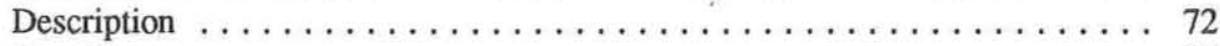

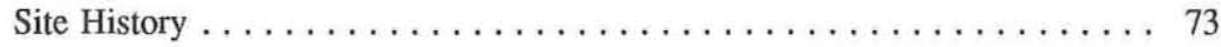

CHAPTER 6: Testing and Evaluation of Previously Recorded Sites

Douglas K. Boyd, Amy C. Earls, Karl W. Kibler, and Andrés Tijerina . . . . . . . . 75

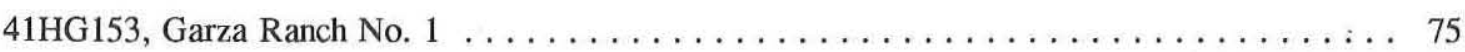

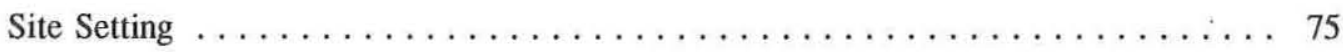

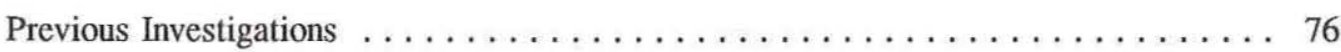

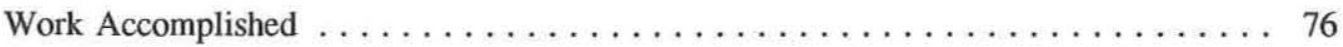




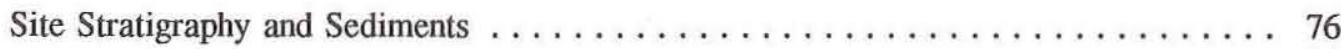

Geoarcheological Implications $\ldots \ldots \ldots \ldots \ldots \ldots \ldots \ldots \ldots \ldots \ldots$

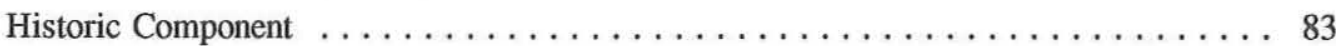

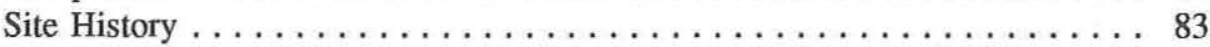

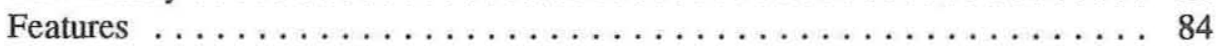

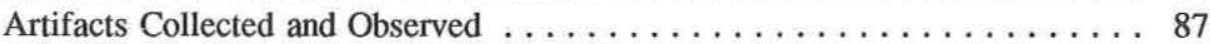

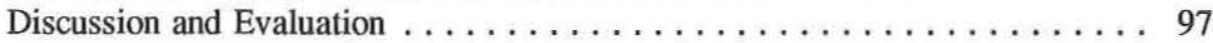

Prehistoric Component $\ldots \ldots \ldots \ldots \ldots \ldots \ldots \ldots \ldots \ldots \ldots \ldots \ldots \ldots$

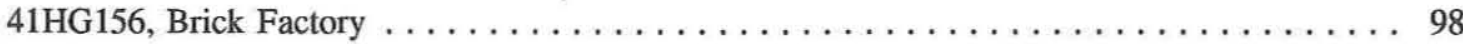

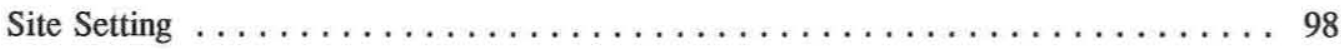

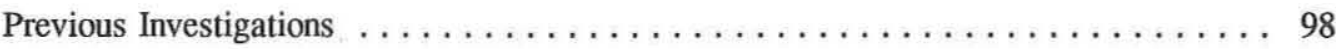

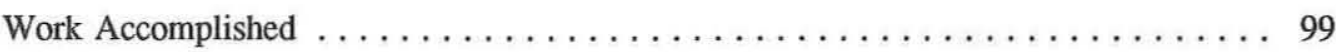

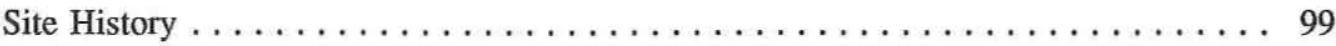

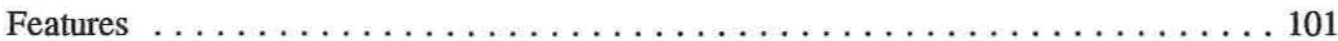

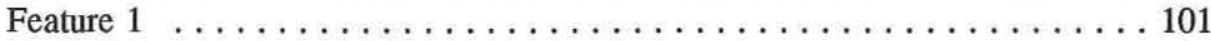

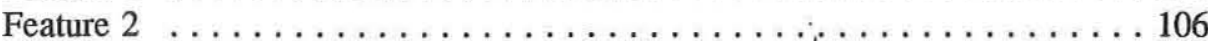

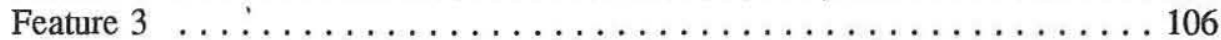

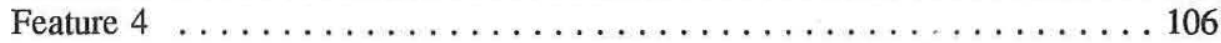

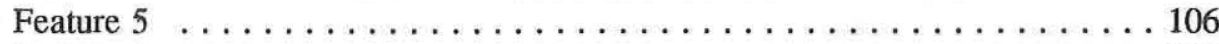

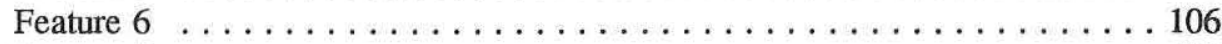

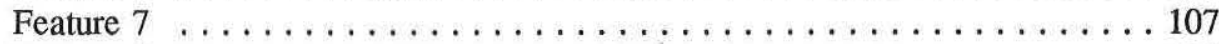

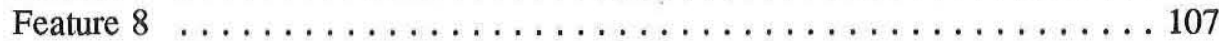

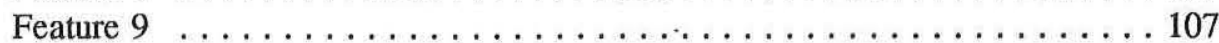

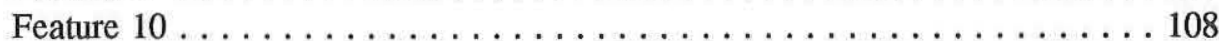

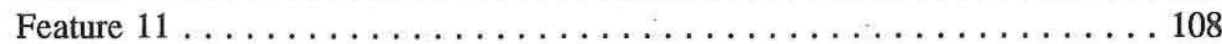

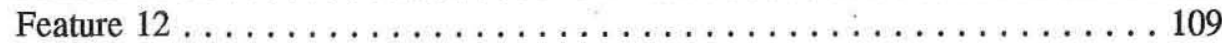

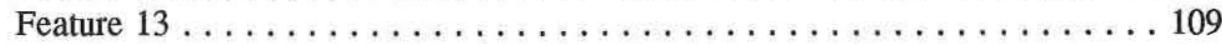

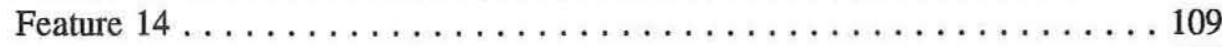

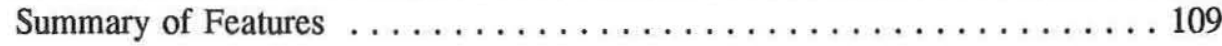

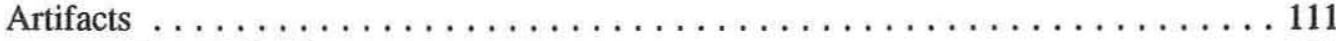

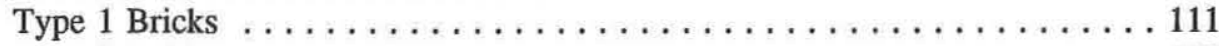

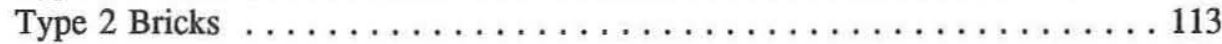

Type 3 Bricks .......................... 114

Discussion . . . . . . . . . . . . . . . . . . . . . . . . . 114

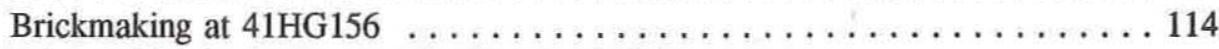

Brickmaking in the Lower Rio Grande Valley

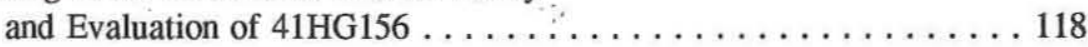

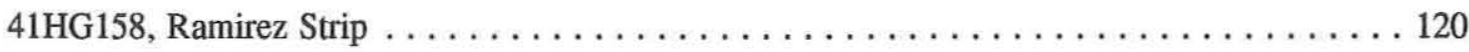

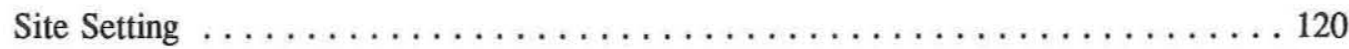

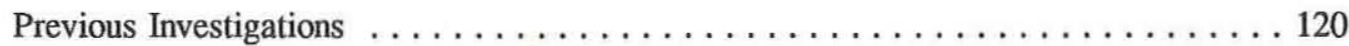

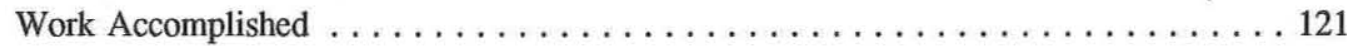

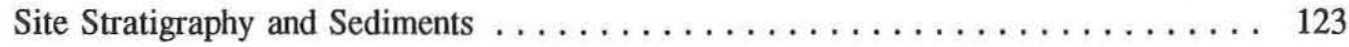

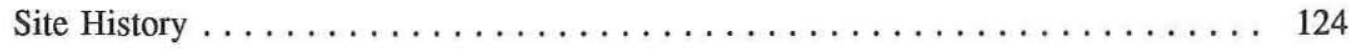

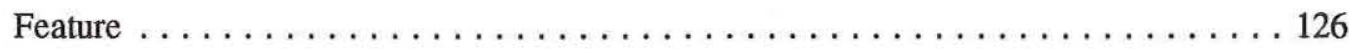




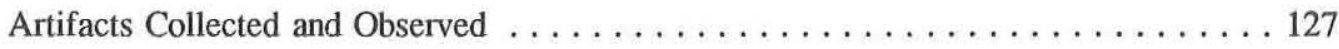

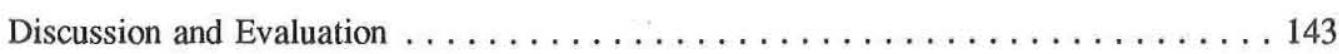

CHAPTER 7: Assessments and Recommendation

Douglas K. Boyd and Martha Doty Freeman . . . . . . . . . . . . . . 145

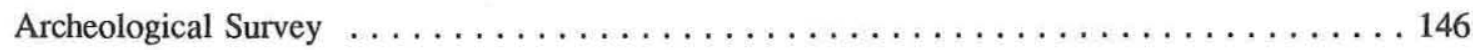

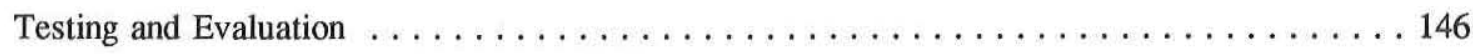

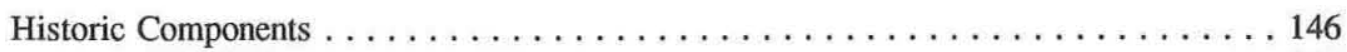

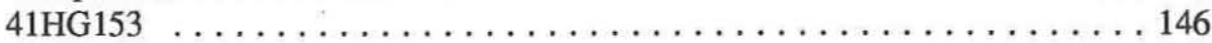

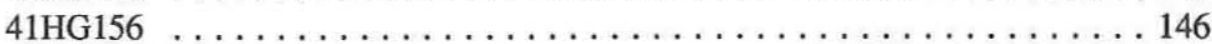

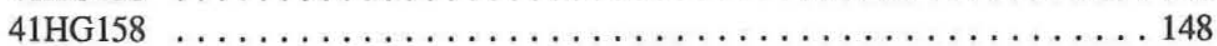

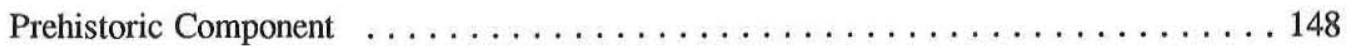

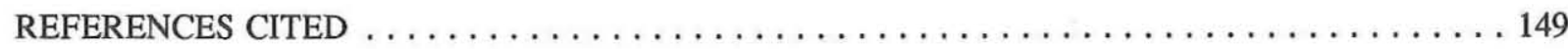

APPENDIX A: Geomorphic Profile Descriptions

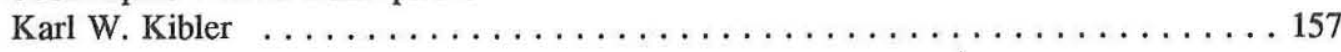

APPENDIX B: Summary and Description of Brick Types Associated with

Dump Features at $41 \mathrm{HG} 156$

Douglas K. Boyd 


\section{LIST OF FIGURES}

1. Project location map $\ldots \ldots \ldots \ldots \ldots \ldots \ldots \ldots \ldots \ldots \ldots \ldots \ldots \ldots \ldots \ldots$

2. Composite map showing the locations of the terrace margin and past and present locations of the Rio Grande channel $\ldots \ldots \ldots \ldots \ldots \ldots \ldots \ldots$

3. Holocene geomorphological features of the project area $\ldots \ldots \ldots \ldots \ldots \ldots \ldots \ldots \ldots$

4. Aerial photograph showing natural vegetation in the project vicinity in $1939 \ldots \ldots \ldots \ldots \ldots$

5. Aerial photograph showing vegetation in the project vicinity in $1990 \ldots \ldots \ldots \ldots \ldots \ldots \ldots$

6. Map of the Lower Rio Grande Valley in the vicinity of Reynosa, Mexico, 1873 . . . . . . . . 29

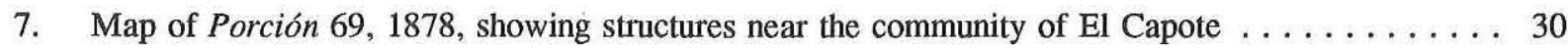

8. Map showing the southern portion of the project area in $1897 \ldots \ldots \ldots \ldots \ldots \ldots \ldots \ldots$

9. Map of the subdivision of Porciones $66,67,69$, and $70,1909 \ldots \ldots \ldots \ldots \ldots \ldots \ldots$

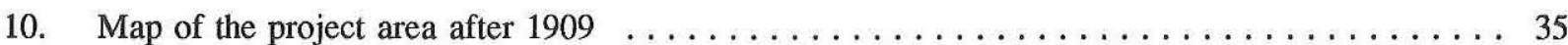

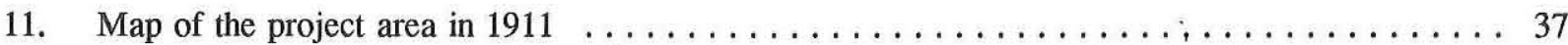

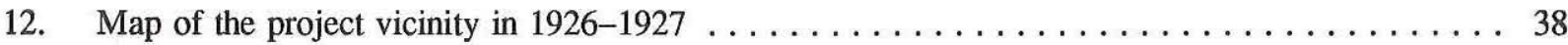

13. Map of the project area showing the locations of newly documented historic sites and previously recorded sites within the area of potential effects $\ldots \ldots \ldots \ldots \ldots \ldots 40$

14. Map of the project area showing locations of known and suspected historic sites outside the area of potential effects $\ldots \ldots \ldots \ldots \ldots \ldots \ldots \ldots \ldots \ldots \ldots 4$

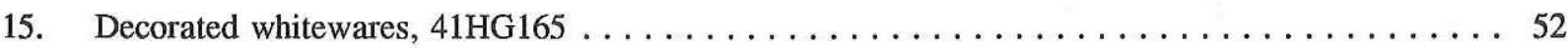

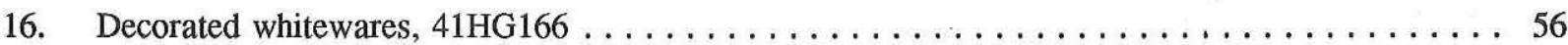

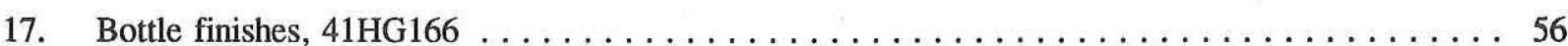

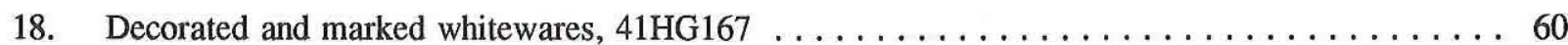

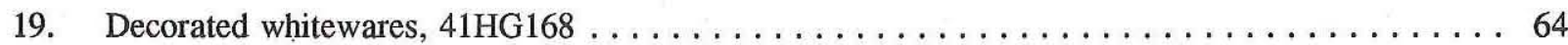

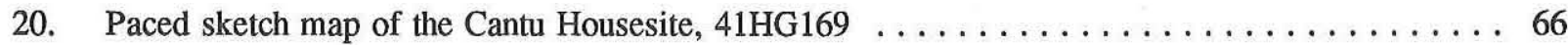

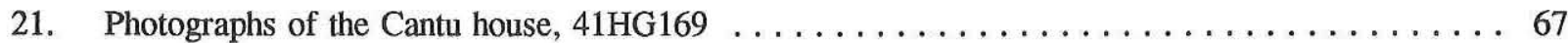

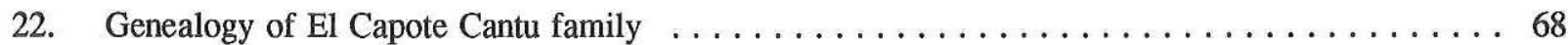

23. Drawings of raised markings on the bricks collected from $41 \mathrm{HG} 169 \ldots \ldots \ldots \ldots \ldots$

24. Genealogy of El Capote Garza family $\ldots \ldots \ldots \ldots \ldots \ldots \ldots \ldots \ldots \ldots \ldots \ldots \ldots \ldots \ldots$

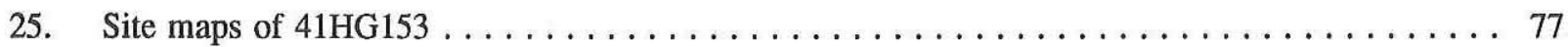

26. Site map showing locations of 1994 backhoe trenches at $41 \mathrm{HG} 153 \ldots \ldots \ldots \ldots \ldots \ldots \ldots$

27. Geomorphic profiles of blade cut and Backhoe Trenches 1993-1 and 1993-5

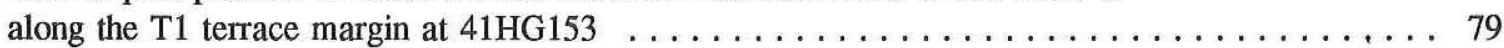

28. Geomorphic profiles of Backhoe Trenches 1994-4, 1994-5, and 1994-6 at 41HG153 . . . . . . 81

29. Generalized cross section of valley fill from the project area and

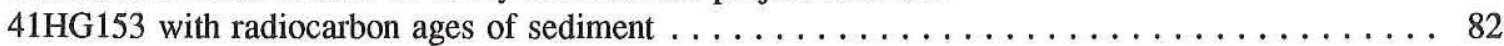

30. Photographs of posthole features exposed in maintainer blade cut at $41 \mathrm{HG} 153 \ldots \ldots \ldots \ldots$ 


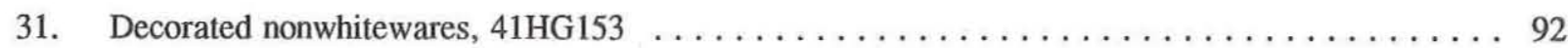

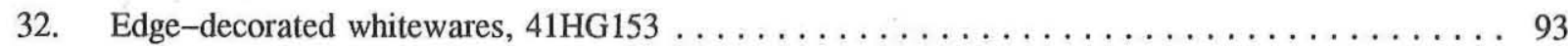

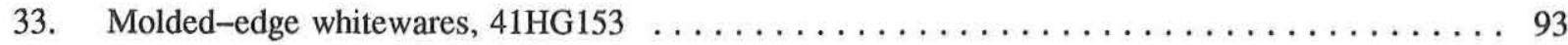

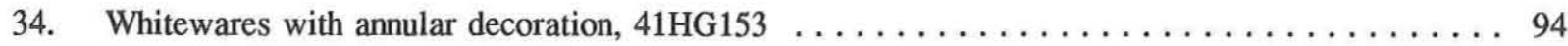

35. Whitewares with underglaze hand-painted decoration, $41 \mathrm{HG} 153 \ldots \ldots \ldots \ldots \ldots \ldots \ldots$

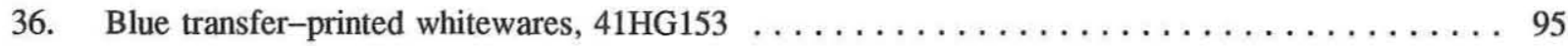

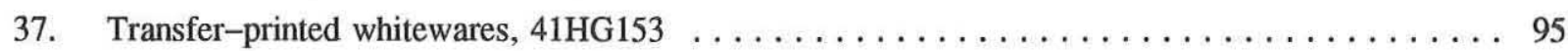

38. Alphabet plate rim with red band and molded $\mathrm{Z}, 41 \mathrm{HG} 153 \ldots \ldots \ldots \ldots \ldots \ldots \ldots$

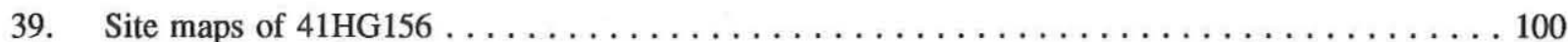

40. Photograph, plan, and profile of Feature 1,41 HG156 $\ldots \ldots \ldots \ldots \ldots \ldots \ldots \ldots \ldots \ldots \ldots$

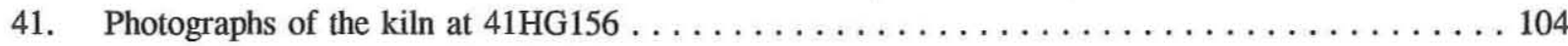

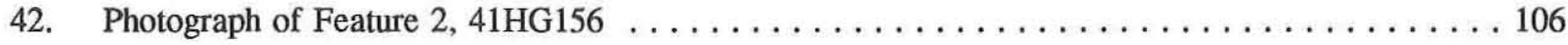

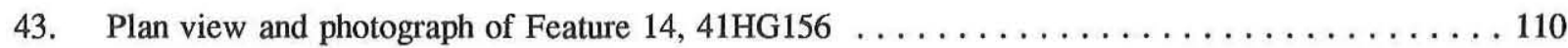

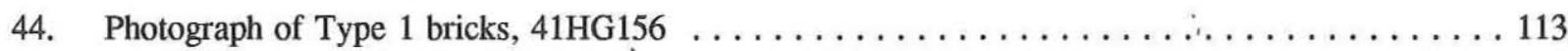

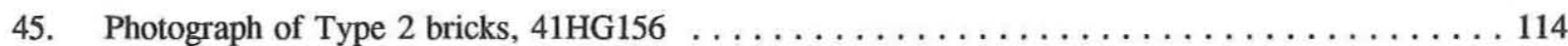

46. Schematic illustration of the brick manufacturing process at 41 HG156 $\ldots \ldots \ldots \ldots \ldots \ldots 116$

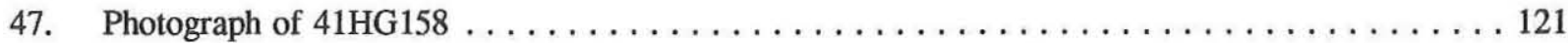

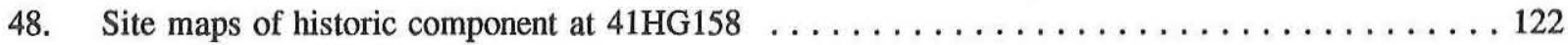

49. Geomorphic profiles of Backhoe Trenches 1 and 4 at $41 \mathrm{HG} 158 \ldots \ldots \ldots \ldots \ldots \ldots \ldots \ldots \ldots \ldots$

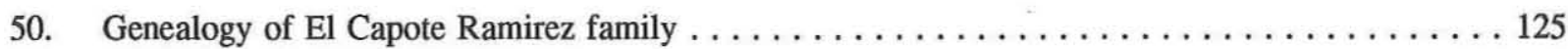

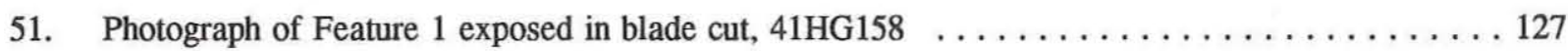

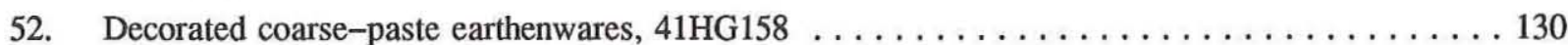

53. Whitewares with annular and sponge decoration, 41 HG158 $\ldots \ldots \ldots \ldots \ldots \ldots \ldots \ldots \ldots \ldots \ldots$

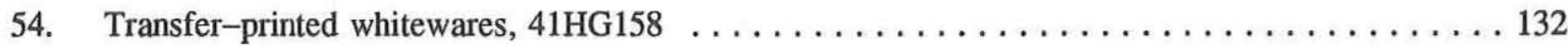

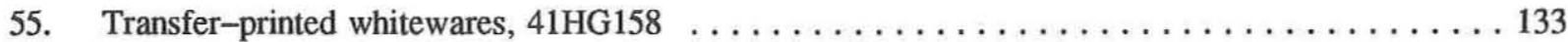

56. Whitewares with decal and molded/painted decoration, 41 HG158 $\ldots \ldots \ldots \ldots \ldots \ldots \ldots \ldots 133$

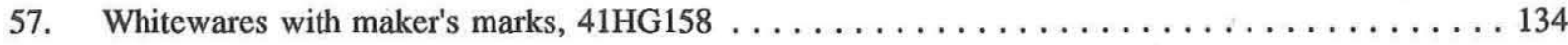

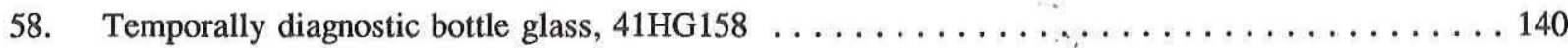

59. Raised mark (possible cattle brand) on brick from Feature 1 , 41 HG158 $\ldots \ldots \ldots \ldots \ldots \ldots 142$

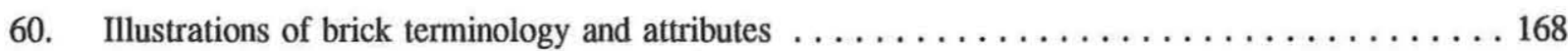

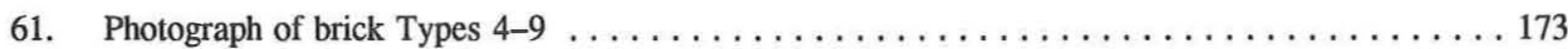

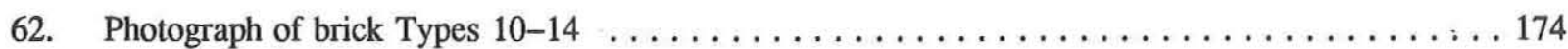

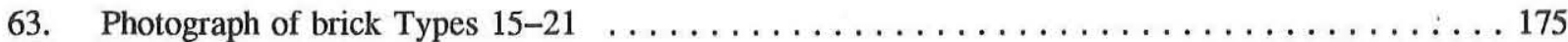

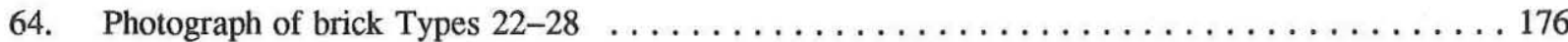

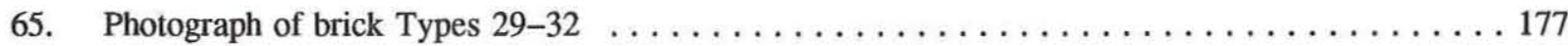

66. Possible cattle brand marks on bricks from 41 HG156 $\ldots \ldots \ldots \ldots \ldots \ldots \ldots \ldots \ldots \ldots$ 


\section{LIST OF TABLES}

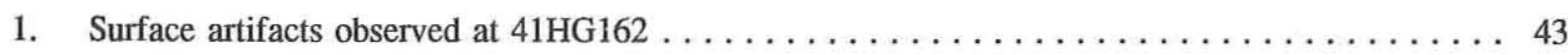

2. Whiteware ceramic decoration types, $41 \mathrm{HG} 162 \ldots \ldots \ldots \ldots \ldots \ldots \ldots \ldots \ldots \ldots \ldots \ldots \ldots \ldots$

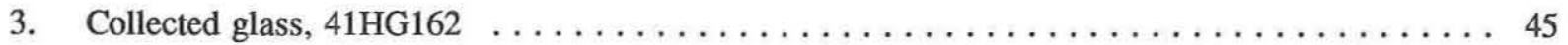

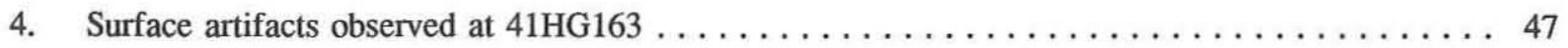

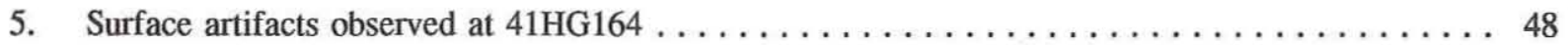

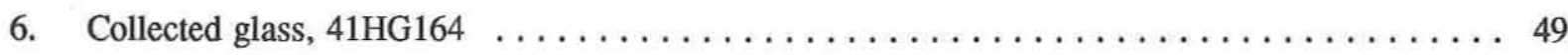

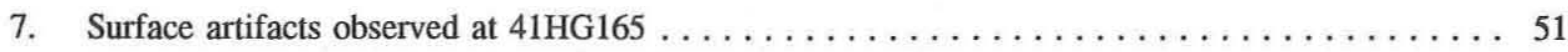

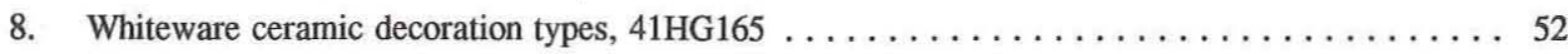

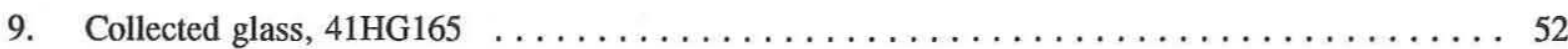

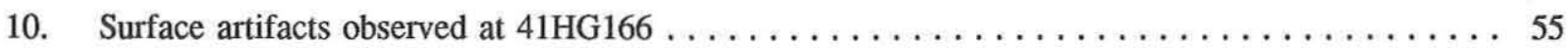

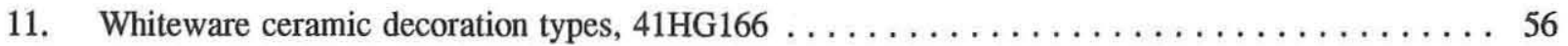

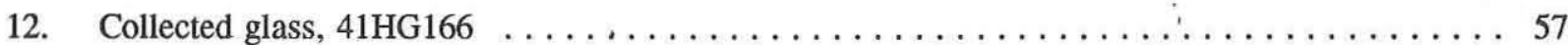

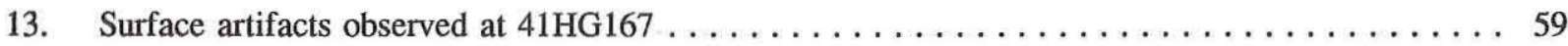

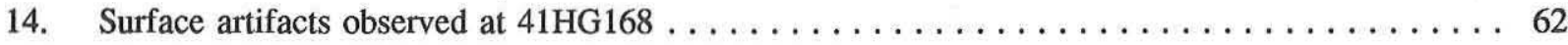

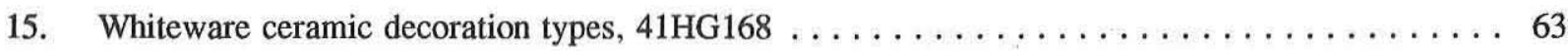

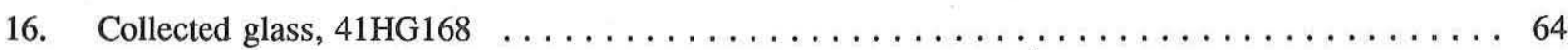

17. Results of radiocarbon dating on humates and charcoal, $41 \mathrm{HG} 153 \ldots \ldots \ldots \ldots \ldots \ldots$

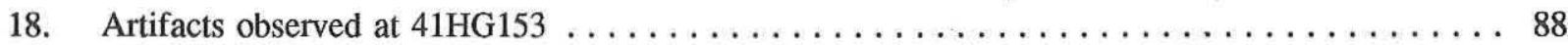

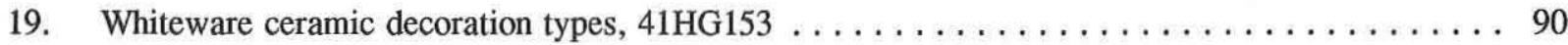

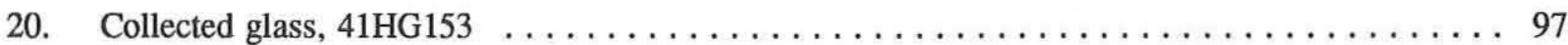

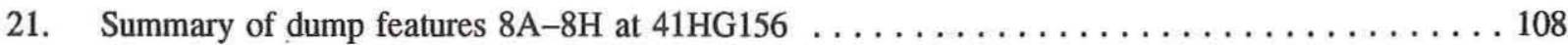

22. Summary of observed and collected bricks by type and provenience, $41 \mathrm{HG} 156 \ldots \ldots \ldots \ldots 112$

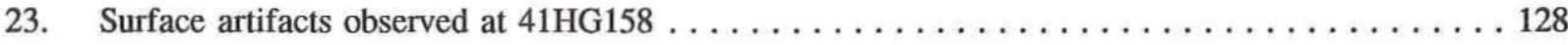

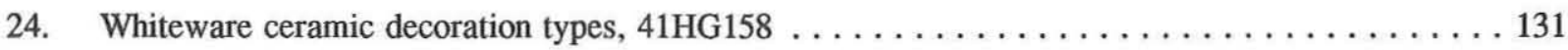

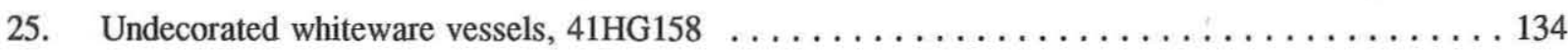

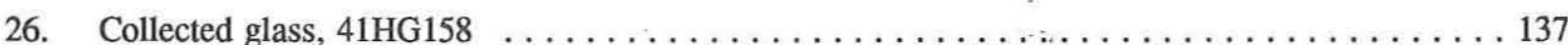

27. Recommendations for National Register and State Archeological Landmark

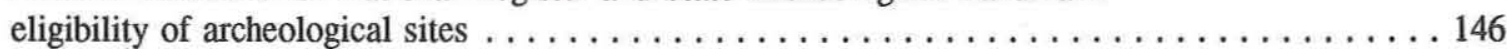

28. Manufacturing processes and sources of brick Types $4-32 \ldots \ldots \ldots \ldots \ldots \ldots \ldots \ldots \ldots \ldots \ldots$ 


\begin{abstract}
Phase II cultural resources investigations for the Pharr-Reynosa International Bridge currently under construction in Hidalgo County, Texas, were conducted by Prewitt and Associates, Inc. in September 1993 and June 1994. The work included additional survey and documentation of seven historic sites, testing and evaluation of three sites, archival and oral history research on the former Hispanic community of El Capote, and collection of additional geoarcheological data.

The seven historic sites (41HG162-41HG168) represent former nineteenth- and twentieth-century housesites within El Capote. Due to a lack of integrity, it is recommended that all seven sites be considered ineligible for listing on the National Register of Historic Places. Three other probable historic sites (Garza Ranch No. 2, a segment of the Old Military Road, and the de la Viña Ranch) are located outside the area of potential effects. These were not recorded, but their locations are noted. Also outside the area of potential effects, a historic housesite (41HG169) contains the only known standing dwelling associated with nineteenth-century El Capote.

Mechanical and hand excavations of the historic components at 41HG153 and 41HG158 revealed severe disturbances and lack of intact features. It is recommended that these sites be considered ineligible for listing on the National Register. Surface and subsurface search for additional evidence of prehistoric occupations at 41HG153 yielded one artifact. It is recommended that the prehistoric component at 41 HG153 also be considered ineligible for listing on the National Register.

Mapping and recording of features at a historic brick factory confirmed the site's high archeological integrity. Site $41 \mathrm{HG} 156$ is the only Ranching Period brick kiln known in the Lower Rio Grande Valley of Texas. It is recommended that it be considered eligible for listing on the National Register.
\end{abstract}




\section{ACKNOWLEDGMENTS}

The investigations for the Pharr-Reynosa International Bridge project were conducted for the City of Pharr, Texas, under the direction of Malcolm Pirnie, Inc., of San Antonio, Texas. Our efforts were coordinated by City employees Pete Sepulveda, Jr. (City Manager), Ernesto S. Silva (Assistant City Manager), and Frank Vecchio (Assistant Public Works Director). Dr. Lynn Kitchen of Malcolm Pirnie served as liaison between Prewitt and Associates and the City. The City of Pharr and their bridge construction contractor, McCarthy Construction Company of Houston, Texas, provided mechanical excavation equipment and operators. Most of the sites that were investigated are located on privately owned lands leased by Elmore-Stahl, and access was provided courtesy of Elmore-Stahl President Bill Robertson and General Manager Wayne Showers.

Elton R. Prewitt served as Co-Principal Investigator and coordinated all aspects of the work. The field work was supervised by Co-Project Archeologists Douglas K. Boyd and Amy C. Earls and Assistant Project Archeologist Karl W. Kibler (who also served as Project Geomorphologist). The field crew included Wayne Klement, Cullom, David Villareal, and Steve Tomka. The archival and oral history research were conducted by consultants Drs. Andrés Tijerina and Joe Graham, respectively, of Texas A\&M University-Kingsville, and their efforts were coordinated by Co-Principal Investigator Martha Doty Freeman.

The contributions of three individuals who assisted in research of a small brick factory (site 41HG156) are gratefully acknowledged. Austin architect Robert Steinbomer visited the site and served as a consultant. His considerable knowledge of brickmaking technology was of critical importance and enabled us to more fully understand this site. Drs. Scott Cook (Department of Anthropology, University of Connecticut) and Joseph Spielberg (Department of Anthropology, Michigan State University) have been researching brickmaking in the Rio Grande Valley for over 10 years and freely shared the fruits of their extensive research. They provided valuable information that allowed us to place the site in its proper regional perspective and to construct a more thoughtful site evaluation.

Seven local residents served as the primary oral history informants and provided valuable information related to the community of El Capote and specific sites within the project area. These individuals are Prudencio Cantu, Roberto Garza, Nestor Garza, Jr., Maria de la Paz, Olivia Ramirez, Rogelio Ramirez, and Edward C. Vela. Other informants who also provided useful historical information include Mrs. Malcom Dyer, Ernestina de la Guerra, Dr. Robert Norton, and Joe Ponce.

This report represents the efforts of not only the authors but also of many Prewitt and Associates staff members whose important contributions cannot be overlooked. Linda Nance Foster served as general editor and produced the report, and Freeman reviewed and edited the work of the historical consultants.

Klement input and edited the field mapping data to generate initial computer site maps, and Ellen Atha did the artifact drawings. Boyd, assisted by Klement and Karen Gardner, took the artifact photographs, while the many detailed figures throughout the report were computer-generated by Sandy Hannum. Gardner assisted in the final layout and paste-up of all of the figures, and Laboratory Manager Jeanine McDonald directed the cleaning, cataloging, and curation of the recovered artifacts.

The authors sincerely appreciate the efforts of all of the people mentioned above but accept full responsibility for any errors or omissions. 


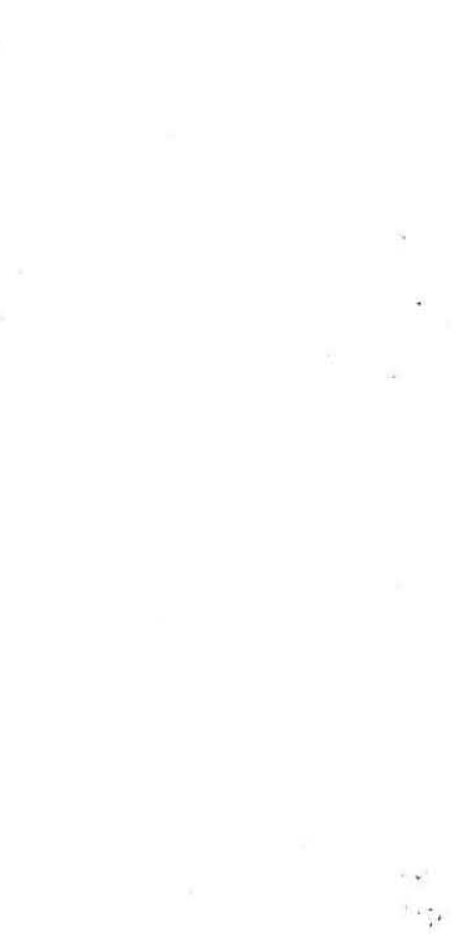




\section{INTRODUCTION AND ENVIRONMENTAL BACKGROUND}

Karl W. Kibler

\section{INTRODUCTION}

Phase II archeological and archival investigations were conducted for the Pharr-Reynosa International Bridge by Prewitt and Associates, Inc. on September 7-15 and 27-30, 1993. Additional mechanical testing was conducted at one site (41HG153) on June 7-9, 1994. The Pharr-Reynosa International Bridge project area is located in south-central Hidalgo County (Figure 1). The project area, consisting of bridge and highway rights-of-way and areas of potential secondary construction impact, encompasses approximately 766 hectares ( 1,895 acres) extending north from the Rio Grande to approximately $350 \mathrm{~m}$ north of U.S. Highway 281 at Fays Corner.

The current investigations included archeological testing and assessment of prehistoric and historic components at $41 \mathrm{HG} 153$ and historic components at $41 \mathrm{HG} 156$ and $41 \mathrm{HG} 158$ and the documentation of eight historic sites within the project area, as defined by the direct impact of bridge construction and an area of potential effects defined by an agreement between the General Services Administration and the Texas Historical Commission. These cultural resources were identified and/or recorded during Phase I investigations conducted by Kibler and Freeman (1993), and sites 41HG153, 41HG156, and 41HG158 were recommended as potentially eligible for listing on the National Register of Historic Places pending Phase II investigations.

The Phase II archeological field investigations were directed by Co-Project Archeologists Amy C.

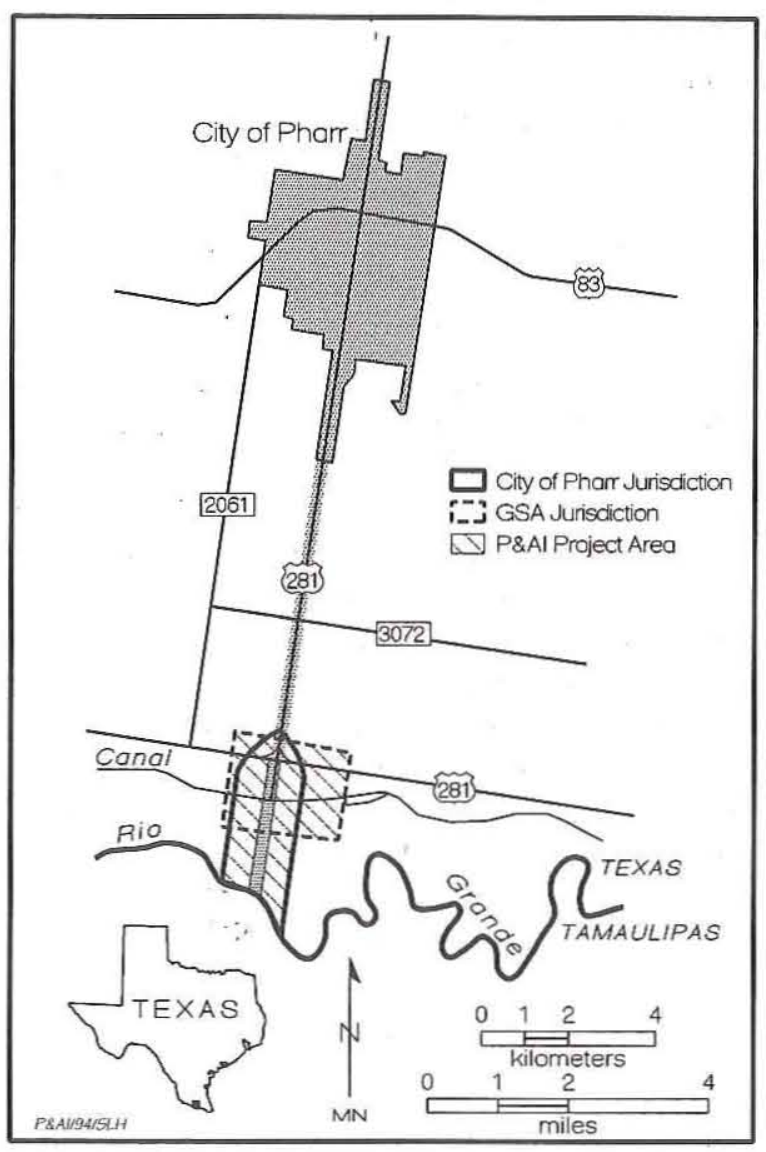

Figure 1. Project location map.

Earls and Douglas K. Boyd and Assistant Project Archeologist and Geomorphologist Karl W. Kibler. Consultants Joe S. Graham (Texas A\&M University-Kingsville), Andrés Tijerina (Texas A\&M 
University-Kingsville), and Robert Steinbomer, AIA (Steinbomer and Associates, Austin) conducted oral histories and provided and collected archival, architectural, and brick manufacturing data. These investigations were conducted under Texas Antiquities Permit No. 1284. The permit and investigations were authorized under the State of Texas Antiquities Code (Texas Natural Resource Code of 1977, Title 9, Chapter 191, VTCS 6145-9); Section 106 of the National Historic Preservation Act of 1966 (P.L. 89-665), as amended in 1980 and 1992; 36 CFR Part 800; and the Archeological and Historic Preservation Act of 1974 (P.L. 93-291), as amended. The investigations were performed under a subcontract with Malcolm Pirnie, Inc. of San Antonio, Texas.

The results of the Phase II investigations, as well as background information essential for placing the investigations in environmental, cultural, and historical contexts, are organized in the following manner. The remaining portion of Chapter 1 provides an overview of the environment of the Lower Rio Grande, including geologic, climatic, pedogenic, floral, and faunal history and data. Chapter 2 provides background information on the prehistory and history of the area. The research design and methods of investigations employed for this project are presented in Chapter 3. Chapter 4 provides an historical overview of the El Capote ranching community. Chapter 5 presents the documentation of eight historic sites within the project area recorded during survey. Chapter 6 presents the testing results and evaluation of the three historic components and one prehistoric component of sites 41HG153, 41HG156, and $41 \mathrm{HG} 158$. Final assessments and recommendations for all the investigations conducted during Phase II are presented in Chapter 7.

\section{ENVIRONMENTAL BACKGROUND}

\section{Geology}

Hidalgo County is located in the Lower Rio Grande Valley, a part of the West Gulf Coast plain section of the Coastal Plain geomorphic province (Hunt 1974:725). The bedrock geology of the province consists of a series of stacked and tilted beds that dip and become progressively younger Gulfward. The Lower Rio Grande Valley is actually a fluvial-deltaic environment consisting mainly of Quaternary channel fill and distributary sands and floodplain and interdistributary muds. Deposition and incision of these sediments have been dictated by cyclical changes in sea level during Quaternary glacial and interglacial periods. The earliest deposits in the Lower Rio Grande Valley are Tertiary and are represented by the Goliad Formation, which consists of Pliocene sands, sandstones, marls, and limestones (Barnes 1976). Pleistocene-age deposits consist of fluvial-deltaic sediments of the Lissie and Beaumont formations. The precise age of these deposits is unclear, although they probably were deposited during the high sea stand of the Sangamon Interglacial period (Brown et al. 1980:17). More-recent Beaumont Formation deposits are the result of fluvial deposition during a later Pleistocene (Peorian?) interglacial stage (Brown et al. 1980:18). 'At the peak of the Last Glacial Maximum around 18,000 B.P., sea level dropped significantly and the Rio Grande cut a deep valley into the Beaumont Formation. At the end of the Pleistocene, sea level began its irregular rise, characterized by an initial period of rapid rise, subsequent still stands, and possible high stands of at least 1.5 and $1.0 \mathrm{~m}$ above current sea level between $4500-3000$ and 2300-1100 B.P., respectively (Frazier 1974; Kibler 1994; Prewitt and Paine 1987). Although the Rio Grande has been a large meandering fluvial system throughout most of the Quaternary (Brown et al. 1980:55), the rise in sea level at the end of the Pleistocene had significant effects on its Holocene alluvial history.

As sea level rose, the Rio Grande Valley flooded, becoming an estuarine environment. Erosion along the margins of the estuary and valley walls widened the original Pleistocene valley. Tidally transported marine sediments were deposited over the earlier estuarine deposits. Around 10,000 to 7000 B.P., this transgressive period ceased and delta progradation took place. The Rio Grande built a sandy wave-dominated delta beyond the modern coastline, until the sediment supply greatly decreased around 4500 B.P., leaving the delta in a transgressive state (Brown et al. 1980:20). As sea level reached its approximate modern level, offshore bars and spits developing from the marine transgressive delta eventually merged with discontinuous offshore barriers to form Padre Island and the Laguna Madre between 3400 and 1900 B.P. (Brown et al. 
1980:22). Landward, beyond the influence of estuarine and marine transgression, the Rio Grande Pleistocene valley slowly filled throughout the Holocene by meanderbelt (point bar) and floodplain deposition (Brown et al. 1980:19).

The present Rio Grande channel is an underfit stream within the Pleistocene valley. Holocene environments of the Rio Grande valley consist of meanderbelt sands and silts, floodbasin and distributary muds, natural levees, crevasse splays, abandoned channels and resacas, local marshes, and headward-eroding streams (Brown et al. 1980:56). Most of these environments are inactive or ephemeral, abandoned by the shifting course of the river. Today, only the present Rio Grande channel periodically floods and deposits sediment. Point bar accretion, levee and crevasse splay building, and the flooding of floodbasins and interdistributary areas only occur during periods of heavy rainfall and run-off related to tropical storms and hurricanes.

\section{Holocene Geomorphology}

Studies of the Holocene alluvial environments and geochronology of the lower Rio Grande are limited (e.g., Brown et al. 1980; Hall et al. 1987). The following overview and interpretations of the Holocene geomorphology are taken from Brown et al. (1980) and the initial studies completed during the Phase I investigations (see Kibler and Freeman 1993). However, the investigations by Kibler (Kibler and Freeman 1993) are limited and the interpretations are not conclusive, primarily due to the dearth of available geomorphic data from the Mexican side of the valley and the limited size of the project area, which excludes a complete cross section of the valley for study. Therefore, the following interpretations of the project area's Holocene geomorphology are tentative and require further study in order to provide more-conclusive statements about the lower Rio Grande's alluvial history.

The project area can be divided into three major geomorphic environments: an alluvial terrace (T1), the modern floodplain (T0), and resacas. These three environments are composed of channel fill sands, interbedded sands and muds of natural levees and crevasse splays, floodplain and interdistributary muds, and lacustrine muds, representing at least two Holocene alluvial fills within the Pleistocene Beaumont Formation valley (Kibler and Freeman 1993:27-33). The Pleistocene valley margin is approximately $8.4 \mathrm{~km}$ north of the project area. Between the project area and the Pleistocene valley wall, several headwarderoding streams and abandoned channels, such as Sardinas Resaca and La Cruz Resaca, formed during the Holocene and have pirated extensive run-off from the northern portions of the valley.

The alluvial terrace or T1 surface covers the vast majority of the project area and is relatively low, only 1 to $2 \mathrm{~m}$ above the modern floodplain or T0 surface. An International Boundary Commission map prepared in 1911 depicts the terrace margin as the "limit of ordinary overflow" (Figure 2). The terrace consists predominantly of muddy floodplain deposits and rare interbedded sands and muds of natural levees and crevasse splays. Channel fill sands are'absent and probably not preserved (Kibler and Freeman 1993:27-33). Low sand percentages and high preservation rates of floodbasin mud deposits are typical of suspendedload fluvial systems (Galloway and Hobday 1983:75) such as the lower Rio Grande.

Two radiocarbon assays from soil humates tentatively suggest that the terrace formed around 1100-1000 B.P. by channel incision and abandonment of the old floodplain (Kibler and Freeman 1993:30-31). However, the possibility exists that frequent high-magnitude floods have masked the true age of channel incision or terrace formation by depositing large volumes of more-recent sediment onto the T1 surface. Based on historic maps and channel fill facies encountered in backhoe trenches excavated on the modern floodplain during the Phase I investigations (see Kibler and Freeman 1993), the Rio Grande channel has migrated laterally up to the terrace margin several times in the past (see Figure 2), making it highly probable that flood waters have inundated the T1 terrace surface and deposited fine overbank sediments. This would account for the very thick, muddy, and fine grained profiles observed throughout the backhoe trenches excavated on the T1 surface. Brown et al. (1980:19) have interpreted the transgression of the Rio Grande delta around 4500 B.P. as a consequence of sediment load reductions in the Rio Grande. A reduced sediment load conceivably would have resulted in channel entrenchment and terrace formation upstream, rendering this time period (4500 B.P.) as a 


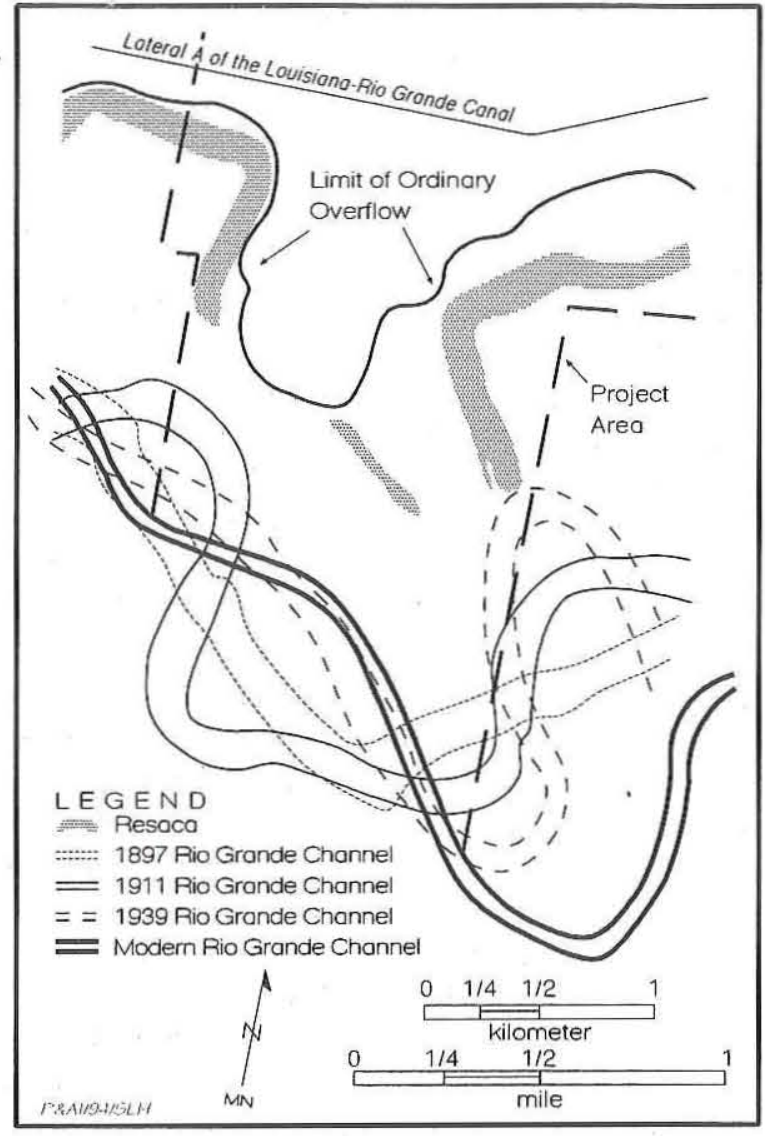

Figure 2. Composite map showing the locations of the terrace margin and past and present locations of the Rio Grande channel. Data compiled from four sources: (1) 1897 International Boundary Commission map (U.S. Department of State 1903:Volume 2:Sheet 34); (2) 1911 International Boundary Commission map map (U.S. Department of State 1913); (3) 1939 U.S. Department of Agriculture, Agricultural Stabilization and Conservation Service aerial photograph (TNRIS: RSDIS \#000243, Frame CGM-8-42); and (4) USGS 7.5' Las Milpas, Texas, quadrangle sheet (1962, photorevised 1983).

probable age of terrace formation within the project area. Based on these initial investigations and interpretations, the $\mathrm{T} 1$ terrace is considered to be late Holocene in age, mostly likely cut between $4500-1000$ B.P.

The number of Holocene alluvial fills or units underlying the T1 surface is not known. The Pleistocene Beaumont Formation was not encountered in any of the backhoe trenches excavated on the terrace surface, and underlying buried surfaces or soils were not encountered or detectable in the thick muddy profiles (Kibler and Freeman 1993). The antiquity of the alluvial fill in the terrace also is not known. An older, higher Holocene terrace surface does not exist in the project area or close to it on the United States side of the Rio Grande. Any older Holocene terrace existing north of the project area may have been eroded away by headward-eroding streams and abandoned channels that become active during periods of high rainfall, or may have been buried by later aggradational episodes and subsequently incorporated into the T1 terrace. Kibler suggests that valley aggradation may have been rapid and steady from the end of the Pleistocene to the late Holocene, resulting in an extremely deep and temporally continuous column of alluvial fill (Kibler and Freeman 1993:31). This is entirely possible considering the extremely low gradient of the Rio Grande and past heavy sediment loads. Brown et al. (1980:56) suggest that meanderbelt sands may be up to $18 \mathrm{~m}$ thick in the Lower Rio Grande Valley since fluvial deposits near the mouth of the river are known to be almost $20 \mathrm{~m}$ thick. Further investigations, including the examination of deep trench profiles and the chronometric dating of soil humates, are needed to support more-conclusive interpretations about the formation and chronology of the T1 terrace within the project area.

The modern floodplain or T0 surface consists of a small narrow strip along the modern channel and is composed of channel fill sands and natural levee and crevasse splay sands and muds (Kibler and Freeman 1993:31). In the western portion of the project area, backhoe trench profiles revealed crevasse splay deposits overlying two welldeveloped soils formed on muddy sediments (probable channel mud plugs or lacustrine muds). The overlying crevasse splay deposits coarsen upward (i.e., the units become increasingly more proximal), indicating that the present channel is moving laterally to the north. The deeper of the two buried soils yielded a $\delta^{13} \mathrm{C}$-corrected radiocarbon assay of $2160 \pm 90$ B.P. Depending on the age of channel incision and terrace formation, this soil may be formed on an erosional inset fill or may be formed on fill associated with the alluvial terrace (Kibler and Freeman 1993:29, 31). Downstream in the eastern portion of the project area, the Rio Grande is laterally accreting a point bar to the south. Backhoe trench profiles from this portion of the project area revealed well-preserved crevasse splays overlying cross-bedded sands (point bar). A bulk sediment sample from the top 
of a buried crevasse splay deposit yielded a modern radiocarbon assay (Kibler and Freeman $1993: 29,31-32$ ). It is fairly clear that much of the alluvial fill examined throughout the profiles of the modern floodplain surface postdates the channel incision that formed the T1 surface. Sedimentary structures are well preserved, and few pedogenic structures or formations are present. An exact age for the initial deposition of this fill is not known; however, it undoubtedly commenced during the late Holocene.

Several abandoned channels or resacas mark the modern floodplain surface (see Figure 2). None of the associated deposits were dated chronometrically; however, all of these resacas most likely are contemporaneous with the later fill of the modern floodplain. Figure 3 shows the Holocene geomorphological features of the project area based on the data, including radiocarbon assays, obtained during the Phase I investigations.

The Rio Grande has undergone recent and abrupt changes due to a reduction in the river's sediment load brought on by the development of large-scale irrigation systems in the Lower Rio Grande Valley and the construction of Falcon and Amistad reservoirs upstream. This has resulted in a decreased channel width-to-depth ratio, an increase in sinuosity, and the cannibalization of point bars. These changes, however, may have been initiated earlier in time by the onset of morexeric climatic conditions established ca. 1000 B.P. Bousman (Bousman et al. 1990:94-95) and Kibler (Kibler and Freeman 1993:33) have noted a dramatic decrease in $\mathrm{C}_{3}$ plant biomass after 2000 B.P. in the Lower Rio Grande Valley based on stable carbon isotope analyses on soil humates. These data concur with other paleoenvironmental data that indicate the establishment of widespread semiarid to arid conditions across Texas, the Southern Plains, and the Southwest (Abbott 1990; Blum and Valastro 1989; Hall 1977, 1988; Holliday 1983).

\section{Climate}

The climate of Hidalgo County can be classified as semiarid subtropical (Natural Fibers Information Center 1987:16). Summers are hot and humid, while winters are mild. On an average of 2 years out of 10 , the temperature never falls below freezing. The average daily maximum temperature is $84^{\circ} \mathrm{F}$, while the average daily minimum is $62^{\circ} \mathrm{F}$ (Natural Fibers Information Center 1987:237). The total annual precipitation is $58.4 \mathrm{~cm}$ ( 23 inches), of which $60 \%$ falls in April through September. The average relative humidity in midafternoon is about $60 \%$. Humidity is higher at night, and the average at dawn is about $90 \%$ (Jacobs 1981:2). The prevailing winds are from the southeast to south-southeast throughout the year, except in December when they become northnorthwesterly (Natural Fibers Information Center 1987:237).

\section{Soils}

Soils within the project area belong to the Harlingen-Runn-Reynosa and Rio GrandeMatamoros soil units or soil associations (Jacobs 1981). The Harlingen-Runn-Reynosa soils are

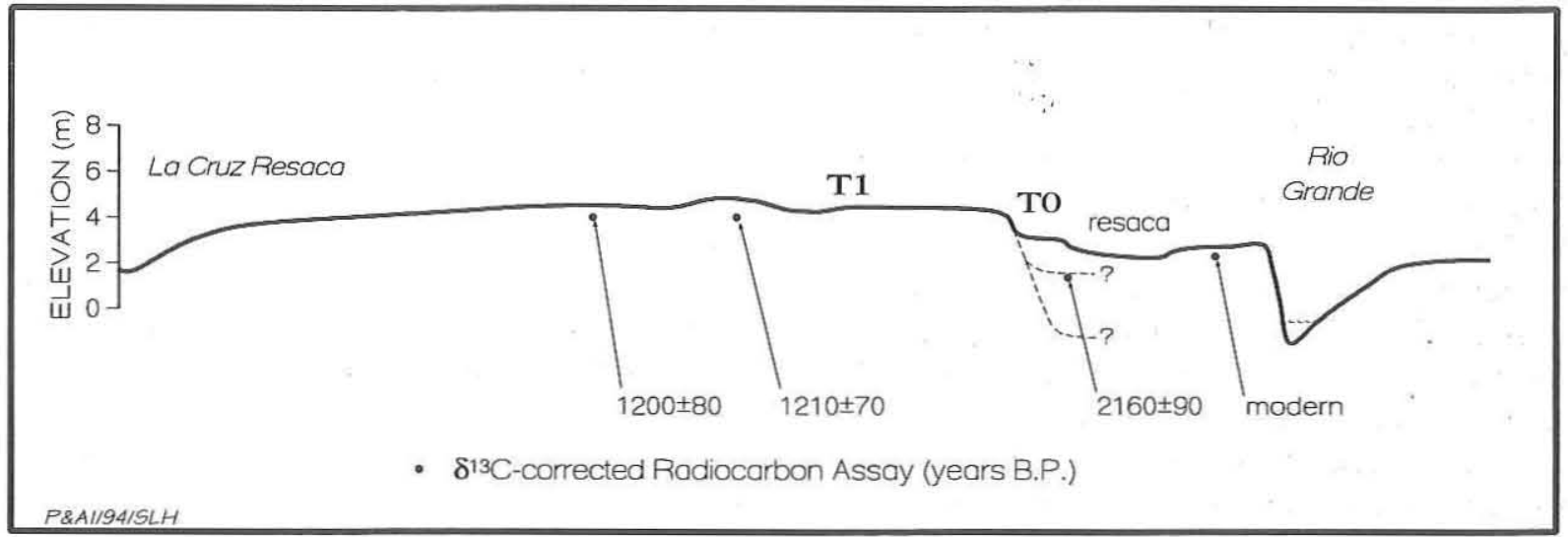

Figure 3. Holocene geomorphological features of the project area. 
associaied with the T1 surface and consist of deep, very slowly to moderately permeable, grayish brown clayey vertic soils formed on older Holocene deposits comprised of floodbasin muds. Soils of the Rio Grande-Matamoros unit are associated with the T0 surface and consist of deep, moderately to slowly permeable, light brownish gray to grayish brown silts formed on more-recent channel fill and channel margin deposits. Grulla soils are also part of the Rio Grande-Matamoros unit and consist of vertic clayey soils formed in oxbows or resacas.

\section{Flora and Fauna}

Blair (1950) characterized the biota of the South Texas Plain as Tamaulipan. However, Blair (1950:103) also noted that, due to the differing nature of the floral and faunal patterns in the lower Rio Grande Valley, the extreme southern portion of the Tamaulipan province be recognized as the Matamoran District. Jahrsdoerfer and Leslie (1988:6-9) recognized 11 biotic communities, based on differences in floral, faunal, climatic, and topographic patterns and characteristics, composing the Matamoran District. They include the Chihuahuan Thorn Forest, Upper Valley Flood Forest, Upland Thorn Scrub, Barretal, Ramaderos, Mid-Valley Riparian Woodland, Sabal Palm Forest, Mid-Delta Thorn Forest, Loma/Tidal Flats, Woodland Potholes and Basins, and Coastal Brushland Potholes.

The project area falls within the Mid-Valley Riparian Woodland community, which parallels the Rio Grande for approximately $80 \mathrm{~km}$ in Hidalgo and Cameron counties (Jahrsdoerfer and Leslie 1988:7-8, Figure 4). Although the project area presently consists almost entirely of cleared agricultural fields, the indigenous floral community (Mid-Valley Riparian Woodland) would have been composed of riparian lands and bottomland deciduous forests (Jahrsdoerfer and Leslie 1988:78). The forested areas in the Mid-Valley Riparian Woodland community support scrub forest, upland thorn scrub, and thorn woodlands. Dominant tree species of the scrub forests include cedar elm (Ulmus crassifolia), sugar hackberry (Celtis laevigata), anaqua (Ehretia anacua), western soapberry (Sapindus drummondii), and ash species (Fraxinus berlandieriana, $F$. pennsylvanica, $F$. texensis). Upland thorn scrub and thorn woodland habitats contain stands of retama (Parkinsonia aculeata), mesquite (Prosopis juliflora), and granjeno (Celtis pallida). In addition, tree species associated with resacas, which are subject to periodic flooding, include retama and huisache (Acacia farnesiana). Beneath these forested canopies thrive several different types of shrubs and vines, including Barbados-cherry malpighia (Malpighia glabra) short-fruited serjania-vine (Serjania brachycarpa), and saw greenbrier (Smilax bona-nox).

The riparian zone along the Rio Grande is limited to a narrow band of vegetation that parallels the river. It includes black willow (Salix niger), Texas ebony/Ebano (Pithecellobium flexicaule), mesquite, giant cane (Arundo donax), common reed (Phragmites commuris), cattail (Typha sp.), and species of rush (Juncus spp.) and sedge (Cyperus spp.). The riparian zone, like the forested areas, provides crucial habitat for aquatic and terrestrial vertebrates (Jahrsdoerfer and Leslie 1988:8).

The Tamaulipan faunal community consists of at least 61 species of mammals, 36 species of snakes, 19 lizards, 2 land turtles, 3 urodeles, and 19 anurans (Blair 1950:103-105). Commonly occurring large mammals include white-tailed deer (Odocoileus virginianus), javelina (Pecari tajacu), bobcat (Lynx rufus), and coyote (Canis latrans). Only a few of the mammalian species are limited to the Matamoran District. They include the Gulf Coast hog-nosed skunk (Conepatus leuconotus), Mexican spiny pocket mouse (Liomys irroratus), and the Coues rice rat (Oryzomys couesi). Other mammalian species such as the jaguar (Felis onca), ocelet (Felis pardalis), fulvous harvest mouse (Reithrodontomys fulvescens), and the nine-banded armadillo (Dasypus novemcinctus) are considered to be neotropical species that are moving or have moved north in the past into the Matamoran District and beyond into other biotic provinces.

The Matamoran District also provides important feeding, nesting, and cover habitats for many species of native and migratory birds. The Matamoran District represents the northernmost extent of 21 bird species that are found in Mexico and Central America (Winckler 1976). The MidValley Riparian Woodland community is the preferred habitat for many rare birds such as orioles (Icterus spp.), chachalacas (Ortalis vetula), and green jays (Cyanocorax yncas) (Jahrsdoerfer 
and Leslie 1988:8).

Human impacts on native vegetation have been severe throughout this century and continue to threaten the survival of this unique ecosystem. Since the 1920 s, more than $95 \%$ of the original native vegetation in the Lower Rio Grande Valley has been converted to agricultural or urban use (U.S. Fish and Wildlife Service 1980) (Figures 4 and 5). More than $90 \%$ of the riparian zone on the United States side of the Rio Grande has been removed (Collins 1984). It is estimated that $98 \%$ of the lush, subtropical region of the delta has been cleared in the United States
(U.S. Fish and Wildlife Service 1980) and a similar percentage has been cleared in Mexico (Collins 1984).

Loss of wildlife habitat through land-clearing activities related to agriculture and development has had a profound impact on many species in the Matamoran District. Eighty-six species, including the ocelot and jaguarundi, are considered endangered, threatened, or placed on notice of review or watchlist by the U.S. Department of the Interior, the State of Texas, or the Texas Organization for Endangered Species (Jahrsdoerfer and Leslie 1988:9, Table 3).

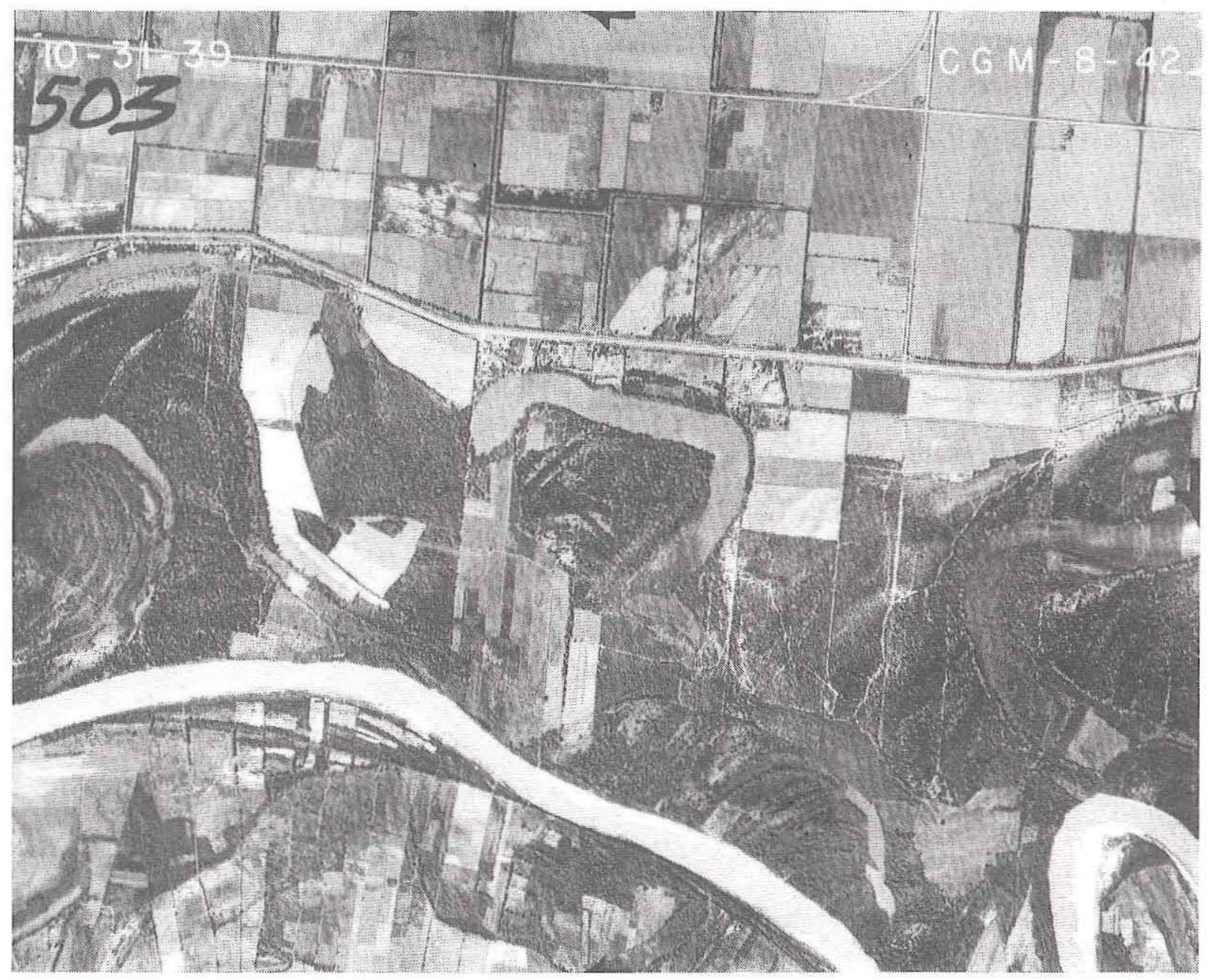

Figure 4. Natural vegetation in the project vicinity in 1939. Black-and-white aerial photograph by U.S. Department of Agriculture, Agricultural Stabilization and Conservation Service (TNRIS: RSDIS \#000243, Frame CGM-8-42, scale 1:20,000). 


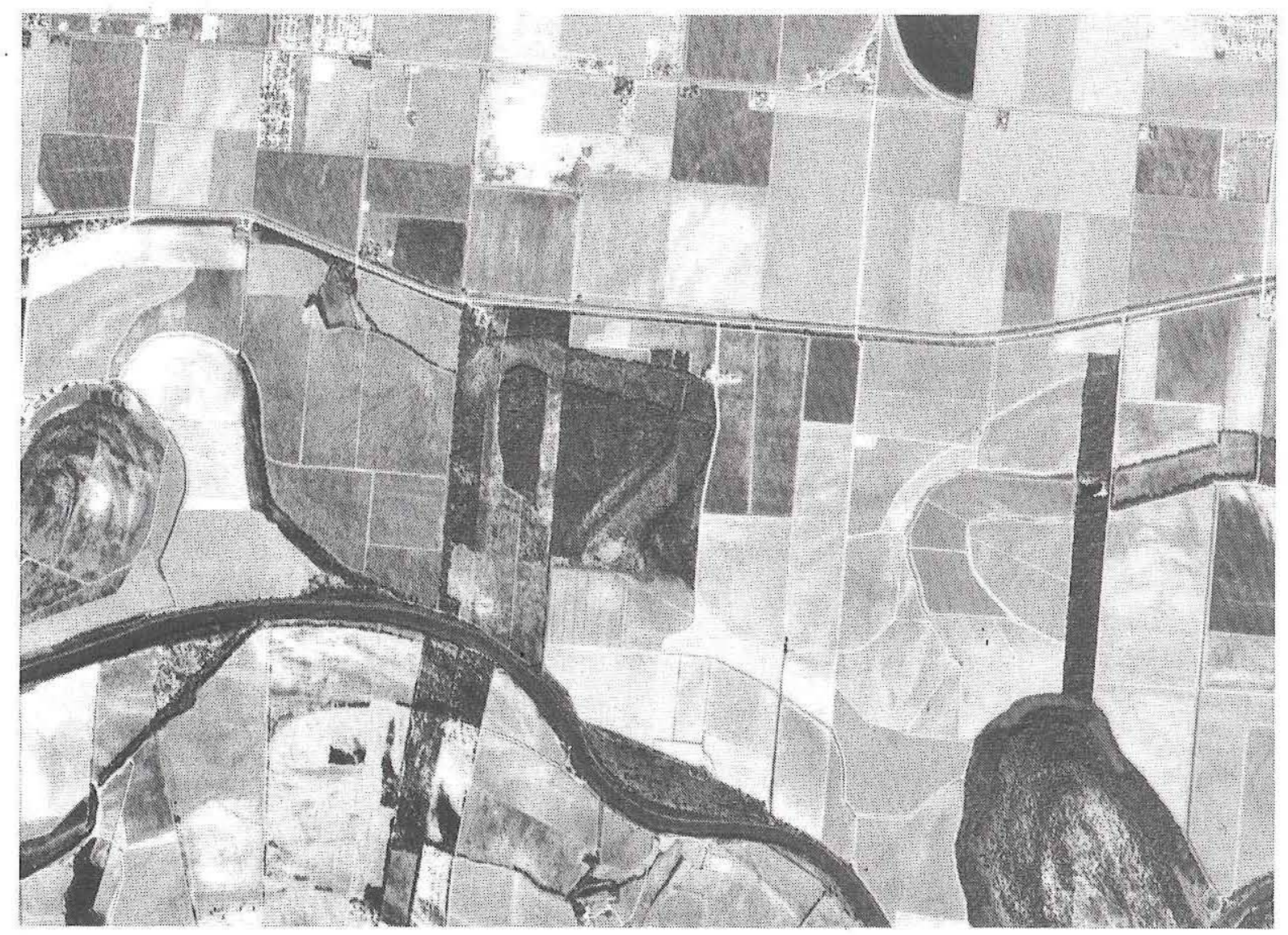

Figure 5. Vegetation in the project vicinity in 1990. Color infrared aerial photograph by the National Aeronautics and Space Administration (TNRIS: NASA-AMES Flight 91-037, Roll 04173, Frame 1778). 


\section{PREHISTORIC AND HISTORIC BACKGROUND}

Andrés Tijerina and Karl W. Kibler

\section{PREHISTORIC BACKGROUND}

An understanding of the prehistory of the Lower Rio Grande Valley remains elusive. Detailed and extensive archeological investigations prior to 1980 are lacking (Hester 1981:119-128). Phases and complexes still either are not defined or are poorly defined, tool assemblages are not well defined, and even projectile point chronology (dominated by simple triangular styles) has not been clearly established at this time (although, see Jelks 1978). Associated with this is the lack of an established absolute chronology for the region, and adding a greater hinderance to an understanding of the region's prehistory are the well-documented land modifications and disturbances related to historical agricultural and ranching activities (Bousman et al. 1990:17-18; Day et al. 1981:1012; Mallouf et al. 1977:23-26). However, even in the absence of historical land disturbances, many deposits representing environments attractive to and utilized by early populations (e.g., Paleoindian and Archaic) of the region may not be preserved, and many of the modern environments that developed during the late Holocene were utilized intermittently or sparsely (Kibler 1994). Attempts to interpret the cultural chronology of the Lower Rio Grande Valley rely heavily on comparsions of artifact and site types with those from surrounding areas such as the Lower Pecos, Central Gulf Coast, Central Texas, and Northeastern Mexico (e.g., Black 1989; Mallouf et al. 1977).

The prehistoric cultural sequence of the
Lower Rio Grande Valley can be divided into three broad periods: Paleoindian, Archaic, and Late Prehistoric. The Paleoindian period $(11,500-$ 7000 B.P.) represents the earliest known cultural manifestation in North America but is poorly known and/or represented in the Lower Rio Grande Valley. The period is often described as having been characterized by small but highly mobile bands of foragers who were specialized hunters of Pleistocene megafauna. However, a more accurate view of Paleoindian lifeways probably includes the utilization of a much wider array of resources, in addition to megafauna. The late Pleistocene and early Holocene environment of the Lower Rio Grande Valley was markedly different than today, offering different resources and subsistence challenges. Paleoenvironmental data from stable isotope studies suggest that temperatures may have been $10-15.4^{\circ} \mathrm{F}$ cooler than today at the end of the Pleistocene (Bousman et al. 1990:97-98). Climatic conditions also probably were arid to semiarid. Bousman et al. (1990:94, 98) have suggested that plant communities were dominated by $\mathrm{C}_{4}$ and/or CAM plants, such as prickly pear and agave. Isolated projectile points collected from surface contexts indicate that the area was occupied by Paleoindian groups; however, intact cultural deposits representing Paleoindian occupations are unknown. Other projectile points have been collected from eolian dune fields in Willacy County (Mallouf et al. 1977:167-168) and the La Perdida site in Starr County (Weir 1956), while a Folsom base was collected from a site 
(41CF54) on Cayo Atascosa (A. E. Anderson field notes, Texas Archeological Research Laboratory [TARL] files).

The Archaic period (7000-800 B.P.) also is poorly represented and understood. The Archaic represents a shift to the hunting and gathering of a wider array of animal and plant resources and a decrease in group mobility (Willey and Phillips 1958:107-108). Early to middle Archaic sites are extremely rare in the Lower Rio Grande Valley; this most likely is due to the onset of more-xeric conditions and eolian deflation of occupational surfaces during the early and middle Holocene (see Bousman et al. 1990; Hall et al. 1987). Evidence of utilization of the Lower Rio Grande Valley by Archaic peoples again comes from surfacecollected artifacts, "primarily by unstemmed triangular thin bifaces, gouges, and infrequent stemmed dart points" (Hall et al. 1987;17-18). Late Archaic sites are not as infrequent, but often their components are mixed with later Late Prehistoric assemblages, e.g., 41HG118 (see Hall et al. 1987). Human remains recovered from the Lower Rio Grande Valley have yielded late Archaic radiocarbon assays (Bousman et al. 1990:99-100), providing the earliest conclusive evidence of human occupation of the area. It probably is no coincidence that the apparent increase in sites during the late Archaic is coeval with the beginning of landscape stability and soil development (Hall et al. 1987:57-59). Moremesic conditions are apparent throughout much of Texas around 2500 B.P. and are represented by a predominance of $\mathrm{C}_{3}$ plants in the region (Bousman et al. 1990:94-95).

MacNeish (1947) defined two Archaic complexes - Abasolo and Repelo-for northeastern Tamaulipas and the Lower Rio Grande Valley based mainly on surface-collected artifacts. Based on stratigraphic position, MacNeish (1958:Table 30 ) estimated that the Repelo complex dates from 5000-4000 B.P. and the Abasolo complex from roughly 4000-2000 B.P. However, few sites bearing Repelo and Abasolo components have been excavated, and radiocarbon assays are not available.

The Late Prehistoric period ( $800-300$ B.P.) is the best known of the three periods. It is defined by the presence of the bow and arrow and marked by the production of small triangular arrow points beginning around 800 B.P. (Hester 1981:
122). The emergence of ceramics and horticulture, which is apparent during the Late Prehistoric period in other parts of Texas, is absent or very nebulous in the region. Increasingly xeric, but modern, conditions emerged at this time. Stable isotope analysis suggests that plant communities were in a state of flux and were marked by a steady increase in $\mathrm{C}_{4}$ grasses (Bousman et al. 1990:94-98).

Sayles (1935) was the first to define a cultural complex for the Lower Rio Grande Valley - the Brownsville phase. MacNeish (1947, 1958:186-192) later defined a Brownsville complex, based on the collections and work of Anderson (1932), Sayles (1935), and Mason (1935). MacNeish (1958) also defined a Barril complex beginning around A.D. 1000 and slightly predating the Brownsville complex. The Brownsville and Barril complexes are characterized by a well-defined shell industry and were determined to be Late Prehistoric based on the presence of small triangular arrow points and Huastecan-like ceramics indicative of the Panuco V and VI periods (MacNeish 1958:189). Prewitt (1974:62) suggests that the Brownsville complex also was contemporaneous with the Rockport phase to the north on the central Gulf Coast of Texas. The Barril complex is distinguished by the presence of rare conical bone projectile points and more-common shell columella projectile points, while the Brownsville complex is uniquely associated with conical pumice pipes. Barril complex sites are largely limited to the south side of the Rio Grande in northeastern Tamaulipas, while Brownsville complex sites are situated north of the river. MacNeish's assemblages, cultural complexes, and their geographical distributions, however, are based only on surface sites and surface-collected artifacts. A few excavated burials and cemetery sites have been attributed to the Brownsville complex, even though radiocarbon assays are not available (Collins et al. 1969; Hester and Rodgers 1971; Hester and Ruecking 1969). The Ayala site was attributed to the Late Prehistoric Brownsville complex due to its stratigraphic position over an earlier Repelo-Abasolo midden (Hester and Ruecking 1969:147).

Historic aboriginal sites are noted by the presence of materials of European origin, including metal and glass projectile points, trade beads, and wheelmade or glazed ceramics. Four historic 
aboriginal sites (41CF8 and three other sites discovered by A. E. Anderson) in Cameron County have yielded glass arrow points and wheelmade or glazed sherds (Anderson 1932; Prewitt 1974). The latest record of aboriginal inhabitants in the area was in A.D. 1886 near Reynosa, Mexico (Salinas 1986:258).

\section{HISTORICAL BACKGROUND}

Several surveys have been conducted of the historic sites and structures along the region of the Lower Rio Grande, including a predictive assessment of cultural resources in Hidalgo and Willacy counties by Mallouf el al. (1977), a survey and assessment of historic cultural resources by Victor (1981), a survey of historic sites between Laredo and Brownsville (Freeman and Sánchez García 1991) and the events that occurred there.

(Thompson 1991), and a survey of the area to be affected by construction of the Pharr-Reynosa International Bridge (Kibler and Freeman 1993).

The Lower Rio Grande Valley of Texas was first explored and settled by Spanish expeditions when this region was part of Mexico, or New Spain as it was called. The colonial administrators originally had intended the region to serve as a "buffer colony" to protect the northern line of New Spain. They called this protective line of defense a frontera. A typical Spanish frontera was a complex of municipalities, presidios or forts, missions, and ranches. The leading edge of the frontera complex was a defensive band of depopulated lands stretching approximately 200 miles in front of the municipalities. The Lower Rio Grande Valley of Texas was established as a frontera complex in 1747, when Don José de Escandon was commissioned to lead a settlement expedition, or entrada, into the region. The Escandón frontera did not make extensive use of the customary missions and presidios, but it did include a line of municipalities and a great concentration of ranches. The ranches were laid in tiers, with a solid line of land grants called porciones along the north bank of the Rio Grande and a wider band of large ranches scattered over roughly the next 100 miles followed by a depopulated zone, or despoblado, to the north. Escandon's entrada successfully laid the systematic settlement which served its purpose in holding the northern frontera despite remoteness and lack of manpower.
By 1835 , over 300 ranches existed in this region, many of which provided the foundation for future Texas towns. The major ranches included San Diego, San Juan, Palo Blanco, Agua Dulce, El Sauz, Los Olmos, San Luis, Pansacol, Zapata, San Ignacio, and Los Saenz. The Escandón frontera also laid the basis for the modern American beef and wool ranching industries.

In their early explorations, Spanish explorers sought trade routes or wealth in minerals, precious metals, or gems. Early exploration of the Lower Rio Grande, however, had failed to produce either wealth or trade. In 1519, Alonzo Álvarez de Piñeda explored the vicinity of the Rio de las Palmas on the Gulf, publishing the first map of the Texas coast. He reportedly sailed into the mouth of a river which some historians believe to have been the Rio Grande, although it remains a disputed interpretation (Weddle 1992:99). In 1520 and 1523, Diego de Camargo and Gonzalo de Ocampo, respectively, attempted to establish permanent settlements in the region, but they were unable to because of hostile Indians and the lack of suitable sites for settlement (Mallouf et al. 1977).

In the early 1530s, Alvár Nuñez Cabeza de Vaca traversed through or near the Lower Rio Grande Basin with a small band of Spaniards and one black Moorish slave named Estéban. Cabeza de Vaca and his band were all that was left of over 300 men who had begun an expedition in Florida in 1528. Shipwrecked on the Texas coast near Galveston Island, the few survivors lived with the Texas Indians, posing as medicine men to stay alive. Although lacking definite strategic information, Cabeza de Vaca's published report was one of the first accounts of the Texas natives. In 1533, Pedro de Alvarado ventured up the Rio Grande, reportedly building a presidio upstream from present-day Brownsville at a site the Spaniards named Las Peñitas in 1682. Las Peñitas was located $14.5 \mathrm{~km}$ west of present-day Mission in Hidalgo County, according to one historian (Mallouf et al. 1977:30). And in 1572, according to historian Robert Weddle (1992:100), one more entrada was led into the Lower Rio Grande in the sixteenth century by Luis de Carvajal y de la Cueva. Carvajal entered Texas from Nuevo León and probably represented the last sixteenth-century regional contact between Spanish and Indian populations.

For the next 100 years, the Spaniards ignored 
the Lower Rio Grande region and Texas because of discouraging reports from the early explorers. There were minor exploratory expeditions by Sergeant Major Jacinto García de Sepulveda in 1638 , who traversed the area from present-day Mier to Brownsville (Sánchez 1992:62), and another by Martín de Rivas and Andrés de Péz. But these also failed to produce any reports of valuable trade or mineral wealth (Weddle 1992:101-104).

In 1685, reports of a French incursion into the Texas Gulf Coast caught the attention of the Spanish viceroy in Mexico City and motivated him to establish the frontera on the Lower Rio Grande. He ordered the exploration and reconnaissance of the Gulf Coast. The investigative entrada was made by a stalwart frontera captain, Alonso de León. De León's entrada took hundreds of soldiers and bearers and hundreds of cattle, horses, and mules across the Rio Grande and into Texas. Besides reporting the failure of the French settlements, De Leon reported that the land was perfect for the grazing of livestock. Indeed, on his return trip and a subsequent entrada in 1689, De León intentionally left many of the livestock on both sides of the river to propagate for posterity. Within three decades, the missions along the San Antonio River were reporting the presence of thousands of livestock grazing freely in the despoblado to the south.

De Leon's reports and the success of the mission herds led Escandon to choose ranches over missions or presidios to settle his own Rio Grande frontera. Ranches had proven advantages on the Spanish frontera. Unlike agricultural crops, for example, livestock could be removed in time of drought or attack. And on the Spanish ranch, the vaqueros were loyal servants whose mounts and skills could be redirected instantly toward the defense of the frontera. Later, one of these advantages would prove troublesome when the region came under United States jurisdiction. Anglo-American judges often interpreted the defensive shifting of livestock as "abandonment" of the ranch.

The legal basis for Escandon's frontera came in a royal cédula or order issued from Spain in 1739. The cédula provided for the formation of a junta, or interim governing group of officials. A subsequent cédula defined the location and extent of the Rio Grande frontera and authorized a search for the leader of the entrada. José de Escandon, the Count of Sierra Gorda, was appointed as conquistador and governor of the Province of Nuevo Santander, an area that was to incorporate the land now in the jurisdiction of South Texas and northern Tamaulipas, Mexico.

Escandon initiated his colonization by recruiting over 6,000 colonists from the northern Nuevo León and Coahuila area. He surveyed the new frontera and organized four expeditions led by himself, Blás María de la Garza Falcón, Miguel de la Garza Falcón, and Joaquin de Orobio Bazterra. Between 1747 and 1755, Escandon established 23 municipalities and 15 missions. He also recruited Spanish mestizo or mixed-blood soldiers and civilians from the Monterrey and Saltillo areas. These mestizos were a mixture of Spanish with Tlascalan natives of the former Aztec Empire in Central Mexico. As súch, they combined the Spanish knowledge of stock raising with the sedentary agrarian culture of the Aztecs. Escandon advertised the potential mineral wealth of the region and its agricultural fertility, promising that it would bring prosperity through crops and trade. In doing so, he became only the first of a long string of developers in a boosterism which would run well into the twentieth century in the Lower Rio Grande Valley.

The Catholic Church also established visitas, or sub-missions, to proselytize among the local Indians, but the missions never developed into a major influence among the natives or the Spanishmestizo settlers. By the mid 1750 s, census reports reflected 6,385 colonists and 2,837 families in the municipalities of the Escandon frontera.

In establishing his colony, Escandon followed the Spanish civil codes of laying out municipalities, which were different from the AngloAmerican concept of towns. As an integral element of the defensive frontera line, the jurisdiction of a Spanish municipality incorporated the area surrounding the town. Thus, the Escandon towns incorporated their lands across the Rio Grande as well as within the town. The validity of the municipality government and the land grants was verified by a Royal Commission sent by the Viceroy in 1767. The General Visit was commissioned to grant titles to vacant land and unappropriated lands in the colony of Nuevo Santander. The Visit thus marked the beginning of individual ownership of land north of the Rio Grande under 
the municipality system of the Spanish government.

Laid along the river, the first tier of land grants was comprised of porciones, the name designating a "portion" of the limited river bank. In order to afford a greater number of colonists with the life-giving waters and the fertile bottomlands, the porciones had a narrow front on the river. To provide the necessary grazing area however, the porciones stretched several miles back from the river, resulting in their characteristic shape of a long rectangular strip. In the words of Mallouf et al. (1977:37), the porciones were "granted to the head of the household of 'each established family of colonists' to provide them with unfailing water for their livestock." Because a Spanish municipality extended its jurisdiction for several miles around, those in the Escandon frontera laid their land grants on both sides of the river with the porciones primarily along, the more fertile north bank. The municipalities of Revilla, Laredo, Mier, Camargo, and Reynosa granted the greatest number of porciones along the Rio Grande. Except for Laredo, the towns were established on the south bank, although as Spanish municipalities, their jurisdiction extended far north of the Rio Grande as well. The porciones typically measured 1,500 varas wide by 2,500 long, although some were 3,000 varas wide.

The second tier of land grants consisted of the larger tracts north of the porciones. These were the sitios de ganado mayor for cattle and horses (major livestock) and the sitios de ganado menor for sheep and goats (minor livestock) and were located on the fertile grasslands suitable for grazing. A third assignment of lands included vacant areas primarily located south of the Rio Grande, although some were located in present-day Zapata County. Inherent in these land grants and in the vacant "buffer zone" to the north was the concept of open-range grazing. Instead of utilizing a fence for demarcation of property, the Spanish stock owners implemented a system of registered stock brands. For utilitarian purposes, then, the premium was on the use of the land rather than on the land itself. Thus, a rancher could sell a large plot of land for very little money on the assumption that he could still use the land after the sale. Incoming Anglo-Americans who had experienced 40-acre farms and the U.S. system of townships often misinterpreted the Hispanic communal use of land and water, thinking that the Spaniard had little regard for the land.

Indeed, the land was valuable not only for its use but also for the prestige it brought to the family. According to Mallouf et al. (1977:38), these grants were not available to all citizens of Nuevo Santander, but usually went instead to "citizens of wealth and status" such as Juan José Hinojosa, captain and chief justice of Reynosa; his son-in-law, José María de Balli; and José Narciso Cavazos, who received enormous grants of land, both along the river and in the uplands. Owners of this land were designated as hijos dalgo, or "sons of nobility," and established ranches to signify their ownership, ranches that were occupied by not only family members but also friends and servants. By the end of the eighteenth century, however, nobility and prestige began to decline in importance, particularly in New Spain where trade with England and the United States began to show more economic advantages than were offered by claim to nobility.

By the closing decades of the eighteenth century, many Spanish subjects in New Spain had begun to perceive themselves as Mexicanos. They had read, as had their North American neighbors, of the enlightened concepts of republicanism, constitutionalism, and equality. Indeed, the Bourbon royal family of Spain had unwittingly encouraged this trend by the turn of the century by introducing administrative and economic changes in New Spain. The liberalization was known as the Bourbon Reforms. One of the reforms was free trade in the New World colonies. But the Bourbons failed to understand that Mexicans did not want free trade with other New World colonies; they wanted increased trade with the United States and England. Mexicans began to reveal a growing spirit of nationalism. This was revealed most strongly in 1807 when Napoleon captured King Ferdinand VII of Spain, leaving the Spanish government temporarily under the control of a liberal parliament or cortes. As the cortes established a new constitutional monarchy, they fell under the strong influence of representatives from northern Mexico, the most liberal. King Ferdinand finally was freed, but he returned to an enlightened Spain and his hold on Mexico had been weakened substanially.

The Mexican Independence movement began in 1810 and led to a long period of unrest. Soldiers stationed in the frontier region of Nuevo 
Santander were recalled to Central Mexico to protect the government, and the remote province suffered from Indian depredations. In 1821 Spanish colonial rule was overthrown, and in 1823 Mexico became a republic. Under the new constitution of 1824 , Nuevo Santander became part of the free state of Tamaulipas, whose northern boundary was the Nueces River. To the north of the Nueces and to the west of the Medina lay Texas, which had been combined with Coahuila to form the new state of Coahuila y Texas. The Mexican Constitution of 1824 emphasized states' rights over the central government, just as the Articles of Confederation had done in the United States before the U.S. constitution. The liberal provisions of the Mexican constitution surrendered ownership and management of the public domain directly to the states. Also during the formation of the Mexican republic, the liberal northern states began a social revolution directed toward economic growth and the introduction of capitalism. While the Spanish codes had always protected land grants for nobility under primogeniture and entail, for example, the new state congresses began to remove these restrictions from the sale of land. Also, the liberal federalists encouraged the resumption of colonization north of the Rio Grande through the Federal Colonization Law of 1824, the Coahuila y Texas Colonization Law of 1825 , and the Colonization Act of 1835. This time, however, colonization was not intended for the defense of the crown's landholdings but for the development of enterprise.

Northern Tamaulipas attracted few Mexican settlers under the new programs because of hostile Indians, the aridity of the area, and lack of productive soils. But Coahuila y Texas did succeed in attracting Anglo-American settlers into Texas. Between 1821 and 1835, the Coahuila $y$ Texas congress gave special concessions to AngloAmericans for cotton gins, water pumps, and other technological devices in an effort to develop the cotton industry in Texas. The Anglo-American cotton planters responded in numbers that overwhelmed the native Mexicans of Texas, or Tejanos. More importantly, immigrant Anglo capitalists set their sights on the untapped resources - the vast herds of unclaimed cattle, the untapped markets in northern Mexico, and the Rio Grande. The headwaters of the Rio Grande nestled the Santa Fe trade, and the Lower Rio Grande connected the entire region to international markets through the mouth of the river at the Gulf of Mexico. For years under Coahuila y Texas, enterprising Anglo-American capitalists and a few ambitious Tejanos struggled against a growing tide of antifederalism in Mexico City. Powerful conservatives such as Antonio Lopez de Santa Anna jealously guarded central control of Mexico's land and resources. Finally, Texas challenged Mexico for its independence in 1835 and became the independent Republic of Texas in 1836.

The Texas Republic was dominated by Anglo-American capitalists who immediately laid claim to the Rio Grande from its headwaters to its mouth at the Gulf. Although Tejanos and Anglo immigrants had jointly borne the brunt of Santa Anna's attacks, idealistic liberalism soon gave way to racial antagonism between Anglo and Tejano. For 15 years under the Texas Republic, Mexicans north of the Rio Grande fought on both fronts. Over two thousand of them claimed headright land grants under the Republic of Texas by swearing to defend Texas against constant campaigns by the army of Mexico. But they also had to defend themselves from newly arrived Anglo-Americans who continued to treat the Tejanos only as foreigners.

As the Mexican army continually crossed the Rio Grande, the Tejanos found themselves between two opposing fronts. The Texas Republic pressed its claim to the Rio Grande, sending one expedition to Santa Fe in 1841 and another to Mier in 1842. Both expeditions were repulsed by the Mexican military but demonstrated the capitalist aims of the Texas leadership. They wanted the Rio Grande. However, the Rio Grande frontier had become an unproductive as well as a hostile environment. Under these conditions, many Tejano ranchers retreated south across the river, temporarily abandoning their livestock and their ranches. Tejanos could not ranch on the land, and AngloAmerican capitalists could not exploit the resources.

In the period of the Texas Republic, transNueces South Texas was a derelict province. To fill the void of government, one armed insurrection emerged and declared the Independent Republic of the Rio Grande. Under the leadership of Antonio Canales, a Rio Grande rancher, a small army of independent ranchers in 1839 and 1840 claimed the land between the Nueces and Ciudad Victoria, 
Tamaulipas. They were suppressed by the Mexican Army, but the incident illustrates the lack of legitimate government during those years (Vigness 1946:56).

The controversy escalated in the mid 1840 s when Texas resolved to be annexed by the United States, maintaining its claim to the Rio Grande. Mexico rejected the claim and stationed its army to the Rio Grande. In 1845, Mexican troops crossed the river, and President James K. Polk declared the move an act of aggression against the United States. He ordered General Zachary Taylor and an army of 3,554 men to the Lower Rio Grande region. The army bivouacked at the mouth of the Nueces River and then marched southwest to the Rio Grande where they established a camp across from Matamoros. A battle near presentday Brownsville opened the Mexican War.

The Mexican War would finally bring order to the Rio Grande frontier. With the war, the U.S. Army and a Texas Ranger police force established order, and the American county system of government replaced the Spanish municipality. The military transportation and quartermaster system finally brought a civilian market system that the Texas Republic could never realize. Conflict in the region, however, continued until the end of the Civil War. In general, the war laid the capitalist infrastructure for the resources of South Texas to reach international markets. One result of these changes was the exchange of land from Tejano hands to Anglo hands.

The capitalist infrastructure materialized as General Taylor pressed into Mexico. His logistical systems opened all lines of communication to the previously untapped hinterland. His army pressed into service all the river ferries between Brownsville and Reynosa in the campaign toward Monterrey. The U.S. Army quartermaster introduced a system of steamboats up the Rio Grande, charting the waterway for future commercialism. Steamboat captains such as Richard King, Mifflin Kenedy, and James O'Donnell were all part of the Americanization of the Rio Grande. Together with Charles Stillman, these men would purchase Taylor's surplus river craft to establish a veritable monopoly of river trade after the war. Also between 1846 and 1848, U.S. troops ranged in the Lower Rio Grande Valley, formalizing roads needed to facilitate transportation. One road (believed to be near present-day U.S. Highway 77) ran north-south through present-day Willacy County. The second road paralleled the Rio Grande. Called the "Old Military Highway," it enabled troop movement and either followed or was located immediately south of present-day U.S. Highway 281. In the present-day project area, it ran 0.7 miles south of Highway 281 .

The Treaty of Guadalupe Hidalgo marked the end of war on February 8, 1848, and established the Rio Grande as the southem boundary of Texas and the United States. Subsequently, Texans and other Americans, many of whom had become familiar with the Lower Rio Grande Valley during the recent war, became attracted to the region with its abundant opportunities for trade and ranching. Like the riverboat captains before them, Anglo merchants had contracted with Taylor's quartermaster system to reap lucrative profits. The merchants included such men as Colonel Henry Kinney at Corpus Christi and Henry Clay Davis. Davis mustered out of the army at Camargo and established his business at Rio Grande City. By 1848 , the riverboats, ferries, and military roads linked the Rio Grande hinterland to the Gulf, and the new countiẹs of Webb, Starr, and Cameron had been formed. On January 14, 1852, Hidalgo County was created from a part of Cameron County. A site opposite Reynosa was selected as the county seat and named Edinburg by two Scotsmen-John Young and John McAllen-who owned the surrounding land. County designation, however, failed to bring lasting peace, for uprisings recurred regularly. Indeed, the county system ushered in a host of new problems to the Lower Rio Grande region.

One problem was the implementation of the county clerk and tax assessor system. The Hispanic municipality traditionally had allowed landowners to retain their own titles and pay user taxes. The Tejanos were not only unfamiliar with the Anglo-Saxon laws, but they were inexperienced in and distrustful of the county clerk system, which required that they submit their coveted land titles and proof of annual tax payments. Their reluctance to comply with the new system exposed Tejanos to legal and nefarious proceedings to dispossess them of their lands.

Montejano (1987:72) cites a statistic in Cameron County to the effect that, by 1882 , a mere 18 Anglos had acquired over a million acres of land, more than four times as much as the Tejano 
landholdings. The Mexican Investigative Commission of 1873 reported that Anglo county officials such as Thaddeus Rhodes of Hidalgo County used their positions to press sheriffs' auctions against Tejanos who were in arrears on their taxes. One county judge, N. P. Norton of Starr County, took land and conducted armed robberies against Mexicans on both sides of the Rio Grande (Comisión Pesquisidora 1874:68).

A study by Victor in 1981 revealed that Anglos used not only sheriffs' auctions but also intermarriage to acquire landholdings in South Texas. Victor's study (in Day et al. 1981:87-119) focused on cultural resources in limited portions of Hidalgo and Willacy counties, organizing the information around four historical phases: (1) early Spanish exploration (1519-1746); (2) Spanish settlement (1746-1836); (3) Lower Rio Grande Valley history prior to railroad and land development (1836-1904); and (4) Lower Rio Grande Valley history after railroad construction from 1904.

Victor summarized the information presented in Mallouf et al. (1977) and several other sources, describing the various Spanish grants made in the region and pointing out the significance of the Hinojosa, Balli, and other Spanish families who received the largest of the land grants. The Hinojosa and Balli families, for example, were residents of Reynosa who "intermarried in order to exercise and maintain both political and economic power in the region." Despite the fact that much of the land was remote and conditions were inhospitable, the Hinojosas and Ballis believed that their grants would increase in value. According to Victor (1981:93), "the enterprise of [these extended families] was a major factor in maintaining the ranching communities throughout the Lower Rio Grande Valley until major development pressures began at the close of the nineteenth century."

Victor summarized the history of the Valley prior to the turn of the century, noting that when Texas became an independent Republic, and then a State, questions arose concerning the validity of grants made by the Spanish and Mexican governments. In 1849-1850, the Bourland-Miller Commission investigated titles in present-day Webb, Starr, Cameron, and Hidalgo counties for the purpose of reaffirming valid titles and identifying invalid titles and vacant land. In some cases, the grantees were found to have not followed the customs requiring permanent residence and ranching, and those titles were declared invalid. In numerous other cases, descendants were able to prove the validity of the titles, and they were confirmed by the State Legislature on September 4, 1850 , and February 18, 1852, despite the loss of the field notes, original titles, and written testimony when the steamboat Anson, on which the Commissioners were traveling, sank at Brazos Santiago.

Many of the Tejano landowners were able to hold on to their lands, but most were not so fortunate. Indeed, even those who quickly learned the Anglo-Saxon legal system did so only by utilizing the services of Anglo-American land lawyers, many of whom then used their privileged position to enrich their own landholdings. Such land lawyers included James Wells, James Powers, and Robert Kleberg. One result of the rapid transfer of lands was discontent on the part of many Tejanos who had lost their land grants. One such Tejano was Juan Cortina of Cameron County, who became a notorious rebel and raided ranches throughout the Valley during 1859. He was pursued by Texas Ranger John S. "Rip" Ford and U.S. Army Colonel Robert E. Lee. As a U.S. Army officer just before the outbreak of the Civil War, Lee traversed Hidalgo County on the Old Military Road from Rio Grande City to Brownsville while patrolling the region in pursuit of such rebels.

During these turbulent times, two separate and unrelated government commissions assiduously collected testimony and statistics on the events between roughly 1850 and 1875 in South Texas. In 1860 , the United States Secretary of War submitted a report to the U.S. House of Representatives entitled "Troubles on Texas Frontier." In 1874, the Comisión Pesquisidora, or Investigative Commission, of the Republic of Mexico also published a compilation of sworn statements and statistics on that period in the Lower Rio Grande region. Together, these two reports offer a rare insight into the violence and lawlessness prevalent along the border. They reveal that while anonymous groups of bandits robbed travelers and rustled cattle, many organized forces represented specific interest groups as well. For example, the Texas Rangers operated from their headquarters on the King Ranch, representing King and other ranchers. Santos Benavides and Santiago Vidaurri led small 
mounted bands out of the Laredo area, protecting business interests and landed families who profited from free trade across the border. According to the Comisión Pesquisidora (1874), King and Hidalgo County Judge Thaddeus Rhodes both financed named individuals who rustled cattle and terrorized small ranchers. Both reports indicate great pressure on the small ranchers to flee the violence or sell their lands.

In 1861, the Civil War came to the Valley where river commerce had been increasing steadily since 1848. A Union blockade of southern shipping ports further stimulated steamboat traffic during the Civil War, and "the Rio Grande became the 'back door of the Confederacy' for the exportation of trade items" (Mallouf et al. 1977:47). Actual Confederate-Union combat was relatively rare in the region, which was abandoned by Union troops from 1861 to 1863 and inadequately manned by Confederates. But Union forces did accomplish a successful raid on the Confederate salt works at El Sal del Rey in 1863, and Colonel John S. ("Rip") Ford conducted guerrilla raids on Union forces in 1864. Hidalgo County saw numerous troop movements on its Military Road, river fords, and ferries. The county also attracted a notable runaway and freed slave community on and adjacent to El Capote Ranch community as Blacks moved southward into Mexico. Finally, the last battle of the Civil War was engaged at Palmito Ranch near the mouth of the Rio Grande where Confederates emerged victorious on May 13, 1865.

After the Civil War, agriculture replaced steamboating as the most profitable business in the Lower Rio Grande Valley. Steamboat captains converted their capital into vast expanses of land. Ranches such as the one owned by Richard King and Mifflin Kenedy became enormously profitable. In addition, early attempts to raise sugar cane met with considerable success when John Closner built a mill in Hidalgo County in the early 1880 s. After 1900 , agriculture expanded with the widespread development of irrigation systems, and by World War I, fruit and vegetable production on small farms owned by Midwestern immigrants had supplanted sugar cane as the basis of the Valley economy. Lured by reports of the extraordinary fertility of the region's soils, colonists were brought by the recently completed rail system and soon transformed the demographics of South Texas. Towns also grew along the new rail lines, and the region rapidly filled with new urban centers surrounded by small farmsteads.

According to Victor (1981:95-96), there were numerous Hispanic agricultural settlements in the Lower Rio Grande Valley prior to the construction of railroads, but these were small ones organized around rural ranches where a few families raised cattle, sheep, and goats. The Hispanic ranches occurred both along the Rio Grande and on the interior prairies, and they were "virtually ... self sustaining establishment[s]" connected by a network of roads. Permanent settlement remained stymied, however, by political unrest, Indian raids, and unfavorable climatic conditions. What the Hispanic ranchers had lacked, according to Montejano (1987:64), was capital. In his words, the Mexican ranchers were land rich and capital poor. The Anglo-Americans, on the other hand, had access to capital which they used to buy the land. Immediately after the Mexican War, merchants and steamboat captains had enjoyed exclusive access to the U.S. Army's lucrative quartermaster contracts. Likewise, after the Civil War, they enjoyed exclusive access to the cattle markets to which they drove 4 million longhorns from South Texas. And with the coming of the railroad, they would gain access to additional markets.

The Lower Rio Grande Valley remained a "sparsely populated ranching area" until the first decade of the twentieth century when railroad construction spurred development of a "populous center of agriculture" (Victor 1981:104). Construction of the St. Louis, Brownsville and Mexico Railroad (SLB\&M) in 1904 was followed by construction of other private rail lines, all of which eventually were incorporated into the Missouri Pacific and Southern Pacific railroad systems. Between 1904 and 1912, these lines included the Sam Fordyce Branch of the SLB\&M that ran west from Brownsville to Sam Fordyce, a line that extended north from San Juan to the townsite of Chapin (renamed Edinburg), and the San Benito and Rio Grande Valley Interurban Railway which connected "Valley towns by a network of spurs and branches."

Initial construction of the SLB\&M was spurred by demonstrations of the agricultural potential of the Valley when George Brulay near Brownsville and John Closner near Hidalgo successfully built irrigation systems and raised 
sugar cane. According to Victor (1981:104), land and irrigation companies began forming in 1904 "for the purpose of developing large tracts of land throughout the Valley. Commercial enterprises had to be dramatically expanded to utilize the new rail system and to keep it operating at a profitable level." Properties immediately adjacent to the railroad were developed first, and towns platted by World War I included Raymondville, Harlingen, Mercedes, Weslaco, Sharyland, and Pharr. Development companies responsible for the towns included the Raymond Town and Improvement Company, Lon C. Hill Town Improvement Company, American Rio Grande Land and Irrigation Company, W. E. Stewart Land Company, Southwestern Land Company, and Louisiana-Rio Grande Canal Company.

Victor (1981:105) noted that "development companies radically changed the face of the lower Rio Grande Valley," inducing prospective buyers and settlers to come from all over the United States to "see the possibilities of agriculture in the Valley." They constructed vast irrigation projects that tempered the arid climate and low annual rainfall, creating images of a "tropical paradise that was verdant, fertile and warm." They also spurred dramatic growth in the Valley's population despite the threat of bandit raids that occurred regularly between 1913 and 1917 so that in Hidalgo County alone the population increased from 6,837 in 1900 to 13,728 in 1940 (Victor 1981:118). Agricultural and railroad development were the two factors most responsible for the "ballooning rate of population," which did not slow sharply until the 1950s as a steady influx of Midwestern farmers bought the subdivided ranchland. Montejano (1987) adds that the labor force for the new commercialized "Magic Valley" was provided largely by the former Hispanic land grantees who had been dispossessed of their large landholdings by 1920 . Many of them became part of a migrant labor force, working the lands and crops of lands once owned by their grandparents. A few of them sold out to the commercial farmers and converted their capital into trucks which they used as labor contractors or as independent truckers (Montejano 1987:114).

A recent study of the Lower Rio Grande Valley region (Thompson 1991) includes a survey of the history of the Valley that summarizes the Spanish exploration of the region, the river settlements of José de Escandón from Laredo to Reynosa, and the role of prominent familes such as the Canos, Hinojosas, Garzas, Garza Falcóns, Cavazoses, Ballis, Sánchezes, Garciás, and Benavideses in the development of the Valley. The survey points out the contribution of the region to the evolution of the Texas cattle industry, the effects of early nineteenth-century revolutions on settlement, events of the Mexican-American War of 1846-1848, and initiation of steamboat traffic on the Rio Grande that stimulated trade and economic growth between the 1840 s and the early 1880 s when railroad construction began to siphon off commerce. The survey describes the impact of Juan Nepomuceno Cortina's raids of 1859 , which were made in retribution for wrongs that Cortina believed his fellow Mexicans had suffered when they were deprived of their property by unscrupulous Anglo speculators.' It also describes the establishment of military posts and camps by the United States government prior to the Civil War as attempts were made to restore peaceful conditions along the river.

The events and battles of the Civil War are described, culminating in the battle at Palmito Ranch. The author also summarizes the numerous raids conducted after the Civil War by Juan Cortina and Catarino Erásmo Garza between 1872 and 1892 and the threat posed by Mexican revolutionary activities of the twentieth century. In counterpoint, the development of the region's industries is described, including brick manufacturing, agriculture, and especially sheep ranching. Railroads are identified as the phenomenon that "brought the greatest growth and change" to the Lower Rio Grande Valley (Thompson 1991:61), and lines mentioned specifically are the narrow-gauge railroad built near Boca Chica for military supplies during the Civil War; Uriah Lott's Corpus Christi, San Diego and Rio Grande Railroad that ran from Corpus Christi to Laredo in the 1870 s and created a boom town by 1881 ; the International and Great Northern from San Antonio to Laredo in 1881; the St. Louis, Brownsville and Mexico Railway from Corpus Christi to present-day Harlingen, San Benito, and Brownsville in 1903-1904; and the Hidalgo or Sam Fordyce line up the Valley through Mercedes, Weslaco, Donna, Alamo, San Juan, Pharr, McAllen, and Mission in 1904.

The study describes the impact of the railroad on the fledgling agricultural industry, noting its 
role in transporting crops throughout the United States and stimulating the development of irrigation farming and raising of sugar cane, vegetables, fruits, and cotton. Land speculators and home buyers came to the Lower Valley in a flood that did not abate until the Great Depression of the 1930s. However, crop production and ranching continued to flourish, providing the mainstays in an economy increasingly dominated by oil and gas production, international trade, and tourism. 



\section{RESEARCH DESIGN AND METHODS OF INVESTIGATIONS}

Douglas K. Boyd, Karl W. Kibler, Andrés Tijerina, and Amy C. Earls

\section{NATURE OF THE CULTURAL RESOURCES AND RESEARCH STRATEG $\dot{Y}$}

Several important characteristics of archeological sites in the Lower Rio Grande Valley have influenced the survey and testing strategies for this project (Kibler and Freeman 1993). Perhaps the most critical of these characteristics is that most of the land (and hence most of the sites) in the Valley has been subjected to some degree of disturbance due to agricultural practices and land modifications related to irrigation and flood control drainage. The U.S. Fish and Wildlife Service (1980) estimates that $95 \%$ of the surface area in the region has been cleared of native vegetation. Researchers have documented the adverse affects of these land modifications on the nature and context of the cultural resources throughout the Lower Rio Grande Valley (Day et al. 1981; Hall et al. 1987; Mallouf et al. 1977). These observations hold true for the Pharr-Reynosa International Bridge project area, most of which has been extensively leveled and currently is being cultivated.

Specifically for prehistoric sites, other factors have contributed to the development of survey and testing strategies. There is a strong relationship between site location and freshwater sources (Mallouf et al. 1977), and sites tend to cluster around five different topographic/geomorphic settings: (1) clay dune-laguna; (2) resaca-laguna; (3) clay dune-lake; (4) resaca; and (5) barrier island (Prewitt 1974). Resacas are the only landform present in the project area, and the margins of these features are considered to be high probability areas (Kibler and Freeman 1993:3, 3334). Unfortunately, site visibility is extremely limited because prehistoric archeological remains tend to be very low density, largely because of a near absence of lithic source materials in the region, and slow continuous deposition over the last 5,000 years has deeply buried most prehistoric sites (Bousman et al. 1990; Hall et al. 1987; Kibler and Freeman 1993).

All of the factors mentioned above have influenced the direction of research for the PharrReynosa International Bridge project. During the initial survey (Kibler and Freeman 1993:23-26), the search for prehistoric sites included a $100 \%$ pedestrian survey of selected high probability areas (i.e., margins of resacas) and $100 \%$ pedestrian survey of randomly selected low probability areas (representing $10 \%$ of the total project area). Backhoe trenches and shovel tests also were used to search for subsurface remains. Although shovel testing proved to be difficult and largely ineffective, a combination of pedestrian survey and backhoe testing has been demonstrated to be a useful technique for locating prehistoric remains and defining their chronological/geomorphic contexts (Kibler and Freeman 1993:34-35).

The search for historic sites during the initial survey concentrated on the comparative use of modern and historic maps (e.g., 1897 and 1911 International Boundary Commission maps; 1936 Texas State Highway map of Hidalgo County; and the USGS 7.5' Las Milpas, Texas, quadrangle 
sheet [1962, photorevised 1983]). This technique proved to be a very efficient means of defining probable site locations for subsequent field checking (Kibler and Freeman 1993:35, 65).

As defined in the work plan, the Phase II testing and evaluation investigations consisted of archival research, oral history collection, airphoto studies, additional survey and documentation of suspected historic housesite locations, and sitespecific testing and detailed recording of prehistoric and historic components at $41 \mathrm{HG} 153$ and historic components at 41HG156 and 41HG158. The objectives and methods of these tasks are described below. All artifacts and records produced during the current project are curated at the Texas Archeological Research Laboratory, The University of Texas at Austin.

\section{HISTORIC ARCHIVAL RESEARCH}

Dr. Andrés Tijerina served as a Project Historian and conducted archival research relating to the project area and the Lower Rio Grande Valley. The research consisted of a review of secondary bibliographies, government documents, maps, private family papers, original manuscripts, and official records in museums and libraries as well as city and county archives. Materials were reviewed for significant and applicable information which then was noted as a standard historical citation. The archival research produced few photocopies and did not include visits to the archeological sites.

The archival research was conducted in Reynosa, Mexico, at the Reynosa Archives, in the sections of the Tesorería, the Presidencia Municipal, and the Correspondencia. Much of the bibliographic and secondary research was conducted in the Rio Grande Valley Historical Collection of The University of Texas Pan American in Edinburg where the historian reviewed rare books and manuscripts, as well as the vertical files on cemeteries, ranches, interviews, and newspaper clippings. The archives of the Hidalgo County Historical Museum in Edinburg also were reviewed for private family papers. Most of the original research was conducted in Edinburg in the deed records, brand record books, maps, Assumed Name Register, and Commissioners Court Minutes of the Hidalgo County Courthouse. Tax records and tax maps were reviewed in the Hidalgo County
Tax Assessor's office. Government documents were reviewed at the Perry-Castañeda Library, and Republic of Texas land and tax records were reviewed at the Center for American History, both at The University of Texas at Austin.

\section{ORAL HISTORY RESEARCH}

Dr. Joe Graham also served as a Project Historian, concentrating on oral history research. $\mathrm{He}$ interviewed the following people regarding the community of El Capote and individual sites within the project area:

1. Olivia Ramirez, a descendant of El Capote Ramirez family, was born in the Ramirez brick house at $41 \mathrm{HG} 158$ in 1930 . She was joined by her brother Rogelio and sister Maria de la Paz.

2. Prudencio Cantu, born ca. 1924, is a descendant of El Capote Cantu family and lived in the standing brick house at 41HG169.

3. Roberto and Nestor Garza, brothers and descendants of El Capote Garza family who settled at $41 \mathrm{HG} 153$. Roberto was born at $41 \mathrm{HG} 153$ in 1907 , and Nestor was born in 1928. They both lived at $41 \mathrm{HG} 165$.

4. Edward C. Vela, born in 1930. His father was Eduardo G. Vela, who bought the land where 41 HG156 is located in the 1940s.

5. Mrs. Malcolm Dyer, long-time resident of El Capote area.

6. Dr. Robert Norton, retired veterinarian who worked in the area of El Capote and is a noted Hidalgo County historian.

7. Ernestina de la Guerra, a relative of the de la Viña family, who taught at El Capote.

8. Joe Ponce, descendant of the de la Viñas who settled the southern portion of El Capote (i.e., the Don Juan Cross Banco No. 155).

Informant interviews were conducted in the vicinity of the project area, generally at the residences of the informants, and in their preferred language (i.e., English or Spanish). When appropriate, the interviews were taped. Written summaries of the interviews and copies of the cassette tapes are curated with the project files at the Texas Archeological Research Laboratory, The University of Texas at Austin.

\section{AIRPHOTO STUDIES}

A study of historic and modern airphotos of 
the project area, conducted by Elton R. Prewitt, had three main goals: (1) to identify possible historic sites and to complement and refine site locations shown on historic maps; (2) to examine the Old Military Road (later called the Brownsville Road) to determine its location, present condition, and relationship to the individual housesites within El Capote; and (3) to determine the extent of recent agricultural land modifications as an aid to understanding the impacts to the cultural resources. Airphotos of the project area were obtained from the Texas Natural Resources Information System's Airphoto Database and include 1939 black-andwhite photos by the U.S. Department of Agriculture, Agricultural Stabilization and Conservation Service (TNRIS: RSDIS \#000242, Frames CGM8-41 to CGM-8-44, scale $1: 20,000$ ) and 1990 color infrared photos by the National Aeronautics and Space Administration (TNRIS: NASA-AMES Flight 91-037, Roll 04173, Frames 1778-1779, scale 1:65,000).

Prior to the beginning of the field investigations, sets of airphotos were viewed stereoscopically to identify unusual and/or manmade features. Locations of historic structures and features were plotted on copies of the airphotos for comparison and cross checking with historic maps and informant data. Locations confirmed as probable historic sites were then transferred to modern USGS topographic quadrangle maps for subsequent field checking. When historic remains were encountered at these locations, they were recorded as archeological sites.

\section{HISTORIC ARCHEOLOGICAL METHODS}

Field checking of possible historic site locations, identified on maps and/or airphotos or by local informants, was done using standard survey methodology. Each suspected location was traversed by pedestrian transects at $15-20-\mathrm{m}$ intervals. Once a site was located, surface artifacts were flagged in place in order to identify site boundaries and artifact concentrations within the site. All artifacts were classified, described, and quantified in the field except for temporally diagnostic specimens, which were collected. These specimens were bagged, labeled by provenience, and returned to the laboratory in Austin to be washed, catalogued, and analyzed. For each site recorded, a State of Texas Archeological Site Data Form was completed, a site map was prepared, and black-and-white print and color slide photographs were taken. Other standard field recording techniques that were employed include plotting of all site locations on USGS 7.5' quadrangle maps, daily journals kept by the CoProject Archeologists, and photographic logs.

More-intensive work (i.e., beyond surveylevel recording) was done at three historic sites. Detailed documentation of 41HG156 included mapping of the surface topography and cultural features with a transit and stadia rod. All surface features were then described in detail (e.g., dimensions, contents, relationships to other features), and selected diagnostic artifacts were collected. At sites 41HG153 and 41HG158, controlled surface collections were made, mechanical testing consisted of using a maintainer to make shallow blade cuts, and backhoe trenches were excavated to better define the buried cultural zone. The stratigraphic profiles of selected trenches at these sites are described in detail (see Appendix A) following the procedures described below in Prehistoric Methods. The locations of all excavations at these sites, as well as the cultural features encountered during mechanical testing, were mapped with a transit and stadia rod.

Historic artifacts, the vast majority of which are ceramics, glass, and bricks, were analyzed using standard techniques and a variety of references to identify the chronology, diagnostic manufacturing attributes, and manufacturing sources of specific artifacts. After being catalogued, the historic artifacts were first sorted into material groups and artifact types. The artifact analysis focused on temporally diagnostic types in order to date site occupations. Greatest weight was given to ceramic and glass artifacts. All collected ceramic and glass artifacts were analyzed regardless of size. Information on noncollected artifacts was taken into account in the vessel analysis. Representative types are illustrated.

Ceramic analysis focused on paste color and glaze type and any additional decoration for coarse- and refined-paste earthenwares and stonewares. Analysis focused on decoration type for whitewares, although ware attributes in terms of vitreosity also were recorded. Vessel forms and marks were distinguished where possible. Minimum number of vessels was defined based on 
ware, decoration type, pattern, color, and vessel form for each site as a whole (not by collection unit). Decoration types generally follow Majewski and O'Brien (1987) and Miller (1991) with additions from Lebo (1991) on stonewares and Moir (1987a) on twentieth-century types. Patterns were identified using Banks (1983), Coysh and Henrywood (1982), Majewski and O'Brien (1987), Price (1979), Williams (1978), and Williams and Weber (1986). Marks were identified using DeBolt (1988), Gates and Ormerod (1982), Godden (1964), Kovel and Kovel (1986), and Lehner (1988).

Glass analysis focused on distinguishing vessel form (container or tableware, and bottle shape or type within the container category) and portion, seams and other temporally diagnostic manufacturing attributes, bore diameter and other measurements, and marks for each glass color category. Glass was examined under a shortwave ultraviolet light for fluorescence indicating lead content. Minimum number of vessels was calculated based on glass color, bottle shape or type, manufacturing attributes, and measurements for each site as a whole. Glass attribute description follows Jones and Sullivan (1989) and Miller and Sullivan (1991). Bottle marks were checked in Fike (1987), Toulouse (1971), and Wilson (1981).

Other artifact descriptions follow examples from early nineteenth-century occupations at Velasco (Earls et al. 1993), Alamo Plaza (Dial 1992) and La Villita (Fox 1986) in San Antonio, the mid-nineteenth-century occupation at Brazos Santiago at the mouth of the Rio Grande (Banks 1983), a late nineteenth-century occupation in Austin (Moore et al. 1972), and a late nineteenth/ early twentieth-century dump in San Antonio (Clark 1984). The brick descriptions correspond with terminology used by Steinbomer (1980) and Gurcke (1987), and brick manufacturing processes and attributes are described in detail in Appendix B.

\section{PREHISTORIC METHODS}

Only one prehistoric component, at 41HG153, was targeted for investigation during the 1993 Phase II field season. The work consisted of excavation of backhoe trenches and a $1-x-1-m$ test unit, transit mapping of all excavation areas, and additional surface survey. Each backhoe trench was monitored closely during excavation, and all stratigraphic profiles subsequently were inspected. Selected profiles that were considered representative were described in detail (see Appendix A for detailed methods and profile descriptions). Sediment zones (a neutral term that refers to stratigraphic and/or pedogenic variation) were numbered sequentially downward from the ground surface. Munsell color (moist), consistency, texture, structure, type and abundance of inclusions, and lower boundary characteristics are described for each zone following the guidelines and criteria of Buol et al. (1980) and Birkeland (1984). Final soil horizon classifications were made based on the guidelines of Birkeland (1984) and Bettis (1984). One charcoal and three bulk sediment samples from the backhoe trenches were submitted for chronometric dating by radiocarbon assay. Age calculation was based on a 5,568-year half-life for ${ }^{14} \mathrm{C}$ and was corrected for carbon isotope fractionation by Beta Analytic, Inc. A calibration factor (Stuiver and Pearson 1993) was applied to the corrected assays to provide a calendrical date.

A $1-x-1-m$ test unit, located adjacent to a backhoe trench, was excavated in $10-\mathrm{cm}$ levels, and pertinent information was recorded on Excavation Level Record Forms. All of the excavated matrix was passed through $1 / 4$-inch-mesh hardware cloth. Since no cultural materials were encountered in the test unit, nothing was collected. The additional survey consisted of pedestrian transects across selected areas to search for prehistoric artifacts. Surface collection procedures are the same as described above in Historic Archeological Methods. 


\section{A HISTORY OF EL CAPOTE}

Andrés Tijerina and Martha Doty Freeman

The project area is comprised of a rectangular block of land located in Hidalgo County, Texas, south of Pharr and east of Hidalgo, Texas, and Reynosa, Mexico. The tract fronts on the Rio Grande and runs north from the river, covering bottomlands, terraces, and first-lift uplands. Because of this configuration, the project area could be said to encompass a representative "slice of history." Moving over land on which early Spanish and Mexican colonial settlement occurred and ranch communities developed, the project area crosses the mid-nineteenth-century Military Road to Brownsville and the early twentieth-century Louisiana-Rio Grande Canal Company Lateral A to enter open fields cleared during the twentiethcentury heyday of the Valley's agricultural boom (Kibler and Freeman 1993:11).

The project area lies entirely within Porciones 69 and 70, two rectangular grants of land within the jurisdiction of Reynosa which was located approximately 3 miles upriver. According to Scott (1970:68-69), the Jurisdiction of Reynosa included 80 porciones which surrounded and were located along the Rio Grande opposite the town. The porciones were surveyed as a result of the 1767 General Visit of the royal Commission to the colonies of Nuevo Santander. Subsequently, the porciones were granted to residents of Reynosa who agreed to "establish stock ranches, to live under military protection and to unite with town people for defense against any invasion; ... not to sell their land to any undesirable persons; and ... [to] take possession of the land within two months after allocation."

The western part of the project area lies in Porción 69, which originally was granted to Juan José Hinojosa by the crown of Spain on October 22, 1767. According to General Land Office and Hidalgo County deed records ${ }^{1}$, Porción 69 was a double porción encompassing 72,250,355 square varas, twice the area of most porciones (Deed Record C:586-587; Texas. General Land Office 1882a). The size of the grant probably was in recognition of the important role Hinojosa played in the founding and early development of Reynosa where he served as captain and chief justice. One of his daughters, Rosa María Hinojosa, married into the influential Balli family of Reynosa, who, with the Hinojosas, "acquired title to most of the river land on its north bank between a point west of the present town of Weslaco and on down to Point Isabel" (Scott 1970:103-104). Juan José Hinojosa owned Porción 69 until September 3, 1794, when he conveyed it to José Matias Cavasos [Cavazos] (Deed Record E:560-561), a resident of Reynosa. Cavasos died, and the land passed to his son, Lino, who conveyed Porción 69 to Rafael Anaya on April 16, 1823 (Deed Record E:562). Following the death of Rafael Anaya, Porción 69 passed to

\footnotetext{
${ }^{1}$ Scott states erroneously (1970:96) that Porción 69 was granted to José Gregorio Camacho and Porción 70 to Juan José Hinojosa (Kibler and Freeman 1993:11). All deed, court, plat, and tax records cited herein are Hidalgo County records.
} 
his heirs, one of whom, Luciano Anaya, passed his interest to a child, Luciana Anaya (Deed Record E:560-562). Another interest passed to María Aloquea Anaya de la Garza (wife of Jesus de la Garza), who had inherited it from Manuel Anaya (Deed Record A:304-305). The Anayas were living on the porción in 1852 when the grant was confirmed to the heirs and assigns of Juan José Hinojosa in February 1852 (Deed Record C:586587). The Garza branch of the family was also on the ranch in the 1850 s according to an 1898 deed record which acknowledged the title claimed by Guillermo Garza, Alejandro Garza, and Isabel Garza de Guajardo. The record stated that the tract was "now, and for many years . . . past, actually held, occupied and possessed by the said Guillermo Garza, and others, Heirs, of the said Valentin Garza, deceased" (Deed Record J:111113). By the 1850 s, the southernmost acreage of the grant was recorded on maps and county records as "El Capote" (the cape). The several descendant families of the original grantees lived on El Capote in homesteads scattered across the southern end of Porción 69 and extending to the eastern edge of Porción 70 along the river.

Porción 70, located immediately east of Porción 69, was granted to José Antonio Velasco by the crown of Spain in 1767 and confirmed to the heirs and assigns of Velasco in 1852. Velasco held Porción 70 until December 24, 1793, when he conveyed it to Marcos Farías (Deed Record I:474476). Farías sold the grant on June 13, 1800, to Pedro Villareal (Deed Record I:479-483). Subsequent owners included Manuel Hinojosa, José Flores, María Rosaria Flores, and María Antonia Gusman, a lineal descendant of José Flores, who sold it to Roland Ritchey on September 4, 1857 (Deed Record A:323-324). Ritchey or his heirs held the property until 1869 when they sold it to Juan Flores (Deed Record B:362).

El Capote had become a typical Tejano ranch community by the early 1850 s, when both Porciones 69 and 70 had been formally granted to the heirs and/or assigns of Juan José Hinojosa and José Antonio Velasco, located on the eastern half of 69 and the western half of 70 south of the present-day Lateral A. Historic artifacts collected from one site in the vicinity of the community (41HG153) and the eastern edge of Porción 69 (41HG168) and county court records suggest that settlement occurred by at least the mid nineteenth century and perhaps prior to 1850 (Amy C. Earls, personal communication 1992; Court Record Book A:63). Artifacts present at a third site (41HG158) confirm both the mid-nineteenth-century occupation (Amy C. Earls, personal communication 1992) and the possible areal extent of the community, which was located between a bench marking the usual limit of overflow and present-day Lateral A.

The ranching communities that developed in South Texas along the Rio Grande were unique in many ways. They had, of course, begun as part of the Escandon frontera and represented the same racial stock of Northern Mexico. They were comprised of mestizos, or Spaniards intermarried with Tlascalan natives of the former Aztec Empire of Central Mexico. A ranch was a self-sufficient communal enterprise with its own families, homes, schools, churches, and cemeteries. El Capote had all these features as well as a public ferry and brick kiln.

One unique feature of ranch life in the Lower Rio Grande Valley was its binational character after the Mexican War. The Tejano families originally had settled north of the Rio Grande as part of Reynosa and the other municipalities on the south bank. The annexation of Texas in 1845 and the Treaty of Guadalupe Hidalgo in 1848 declared them legally American citizens, but they continued to look south for their cultural and economic vitality. Their family roots were in Reynosa, and they bought many of their provisions there, according to an early historical study (Gonzalez 1930:15). In their daily lives, they maintained a truly binational culture. Many of them owned land on both sides of the river and paid taxes to the Municipality of Reynosa as well as to Hidalgo County. In the case of the de la Viña family, an El Capote ranch family who lived on the fringe of the project area, they held official positions in both jurisdictions. Don Manuel de la Viña was on the Reynosa Ayuntamiento (City Council) in the 1840s when he and his sons, Plutarco and Juan, paid taxes there. Later, Plutarco and Juan would serve as Hidalgo County commissioners and judges and help to incorporate the city of Edinburg (Archivo Historico de Reynosa; Washington 1983:83).

A typical ranch community consisted of one or two large, extended families. The extended family was headed by an elder patriarch or matriarch who guided the sons and daughters in rearing their own families on the ranch. The 
families considered the patriarch or "don" to be the owner of the land, although they all lived on the ranch and considered the land to belong to all of them communally as well. This caused some confusion after the municipality system was replaced by the county clerk system and the traditions of primogeniture and entail began to disappear. County deed records reveal a confusing pattern of land partitioning as the families began to sell the lands in the late nineteenth century. El Capote was home to four extended families. Although family lines and home sites almost defy classification, generally the Garza and Anaya families lived on Porción 69, or the western part of the ranch, and the Ramirez and de la Viña families lived on the Porción 70 segment of El Capote. Each extended family lived in its own cluster of homes, and all shared the church and cemetery. The Anayas lived closest to site 41HG156, the Garzas nearest to $41 \mathrm{HG} 153$, the Ramirezes at site $41 \mathrm{HG} 158$, and the de la Viñas on an island now encompassed by the Don Juan Cross Banco. In 1880, 229 individuals were living in 47 households at El Capote (U.S. Bureau of the Census 1880).

Housing types at El Capote were generally a jacal de leña or a casa de reboque until the late nineteenth or early twentieth century, then boardand-batten construction or brick. The jacal was usually a simple, one-room shack made of upright mesquite logs driven a foot or so into the ground. The corners were heavy logs called horcones which were forked at the top to hold the roof beams, or vigas. The jacal had a gabled roof of thatching, or techo de dos aguas de sacate, and a floor of cemented pea gravel, or chipichil. It often had a front porch covered with loosely spread mesquite branches called a ramada. Larger jacales had more than one room and a stone chimney. After living initially in a jacal, a family customarily moved up to a secondary or improved house called a casa de roboque. The casa de reboque was a larger jacal with the walls plastered with mud or lime to make it white inside and out. Those at El Capote had up to four rooms, a chimney, closets, and brick floors. The houses at El Capote also had large gardens of 5 to 6 acres where the families planted corn, chickpeas, watermelon, and other crops for their own consumption (Ramirez et al. 1993).

In the turbulent years between the 1836 Texas Revolution and the Civil War in 1861, South Texas experienced a virtual absence of government, law, and order. And El Capote appears to have been geographically in the epicenter of the violence. El Capote was not only on the bank of the disputed boundary between the United States and Mexico, but also between Brownsville and Laredo where roving bands and armies crossed the river and crisscrossed the land. Hostile Apaches and Comanches took advantage of the opportunity to raid isolated ranch communities. In 1837, a major raid of over 400 Indians reportedly attacked all the ranches in the Camargo, Reynosa, and Matamoros areas (Vigness 1946:37-38). Two years later, a Rio Grande rancher, Antonio Canales, led a small army of his self-proclaimed Republic of the Rio Grande. The would-be republicans hoped to fill the void of government in the disputed land between Mexico and the Republic of Texas. Canales attracted Mexican federalists such as Manuel de la Viña in support of free trade for the Lower Rio Grande region. De la Viña, whose family would figure prominently at El Capote and in Hidalgo County, signed the official peace treaty ending the Canales revolt. A decade later, Hidalgo County became the focus of another conflict as José María Jesús Carvajal launched a revolt against the Mexican government restrictions to free trade between South Texas and Mexico. In 1851, Carvajal fled from his headquarters in Rio Grande City to Hidalgo County where his army was finally scattered. According to reports, the Hidalgo County ranches suffered raids and plunder by the opposing forces in the revolt (Gonzalez 1930:16; Vigness 1946:56). All of these troop movements reportedly crossed the several river ferries in Hidalgo and other South Texas counties. In 1860, the U.S. Secretary of War reported numerous raids by Mexican bandits in South Texas (U.S. 36th Congress, 1st Session 1860). A Mexican investigative commission report (Comisión Pesquisidora 1874:106) also mentions numerous raids by Anglo bandits. One of these crossed the river on the ferry at El Capote in his escape.

On March 25, 1853, Starr County District Judge N. P. Norton led 50 bandits. to sack Reynosa, holding Alcalde Trinidad Flores hostage for a ransom of 30,000 pesos. Norton took the town's cattle and livestock and escaped by crossing the ferry and river ford (vado) at El Capote at 5 p.m. on March 26, 1853 . A case was filed against Norton in Brownsville, but he avoided 
conviction (Comisión Pesquisidora 1874). The same report identified rancher Richard King, Hidalgo County Judge Thaddeus Rhodes, and other so-called "robavacas" (cattle rustlers) as financing cattle rustling in Hidalgo County (Comisión Pesquisidora 1874:106; Herrera Perez 1989:68). Rhodes, who was called "Teodoro" by the locals, reportedly supported a gang of 30 cattle rustlers on his Rosario Ranch in Hidalgo County. $\mathrm{He}$ regularly raided local ranches and traded in stolen livestock. After years of using his county position to protect his land and cattle acquisitions, he finally was imprisoned in 1858 when stolen cattle were found on his ranch as evidence (Comisión Pesquisidora 1874:18-19). The Hidalgo County court records reveal that, as county judge, Thaddeus M. Rhodes later imposed sheriff's auctions to obtain many parcels of land, including land from El Capote. In 1878, for example, he bought a 30-acre tract in Porción 69 from Josefa Cavazos and held a sheriff's auction on 668 acres of Concepción Anaya's part of the porción. Anaya sold her land, instead, to Manuel Cantu, who lived at El Capote (Court Record Book A:149). El Capote families also fended off the efforts of Edward Dougherty, Martin Norgrave, and Jacob T. George, who attempted during these years to acquire an interest in Porción 69 from members of the Anaya and Garza families (Deed Record A:304-305).

One of the most notorious rebels in South Texas was Juan Nepomuceno Cortina, who operated for years out of the Brownsville area after 1859. Cortina issued proclamations in protest of the land usurpation by Anglos in South Texas and used the Old Military Road and ferries in Hidalgo County in his troop movements, but there is no documentation that he visited or attacked El Capote proper. His pursuers, including Brevet Colonel Robert E. Lee, did, however, traverse El Capote in pursuit of Cortina's army. On Christmas Day of 1859, U.S. Army Major S. P. Heintzelman led troops in pursuit of Cortina into Hidalgo County. Heintzelman recorded that "the next place I was told that we should certainly meet him [Cortina] was in a bend of the river a mile beyond-Edinburg [present-day Hidalgo]. We reached Edinburg on Sunday, the 25th of December." The next spring, Colonel Robert E. Lee led a troop from Rio Grande City to Brownsville, stopping at Edinburg [present-day Hidalgo] to issue a proclamation. On April 9, 1860, Lee moved to a "Camp below Edinburg" where he issued another letter to the authorities of Reynosa, and then proceeded down the Military Road which traverses El Capote to Brownsville (U.S. 36th Congress, 1st Session 1860:8, 88). The Military Road through El Capote later was used extensively by Confederate Colonel John S. "Rip" Ford during the Civil War. In November 1861, for example, Ford reportedly "blocked the ferries across the Rio Grande" in order to preserve neutrality after Carvajal's army attacked Matamoros. The next spring, Carvajal and 500 troops crossed the river from Texas and attacked Reynosa as reported by the Fort Brown Flag of Brownsville (Tyler 1973:63). In these incidents, and after the Battle of Las Rucias Ranch in 1864, Ford used the Military Road for troop movements. Ford also reportedly used the ferries in the Hidalgo County area in pursuit of raiders (Pierce 1917:48).

In the 1850 s and the 1860 s, El Capote ranch families began to play an increasingly important role in the community and the county. Two maps, the one by the Comision Pesquisidora prepared in 1873 (Figure 6) and a General Land Office map of 1878 (Figure 7), depict the location of El Capote on the riverbank at the south end of Porciones 69 and 70. In addition, an 1871 hand-drawn map in the Hidalgo County court records depicts El Capote along the river in Precinct No. 1 (Court Record Book A:114). With one of the river ferries and a well-known river ford, El Capote was a regular stopping point for the steamboat trade up and down the Rio Grande. As early as 1822 , according to New Orleans customs manifests, schooners like the Jealous shipped such items as dry goods, crockery, glass ware, and tobacco to Matamoros where carts or carretas then carried them inland to the ranch comunities. After the Mexican War, U.S Army quartermaster surplus steamboats were sold to commercial enterprisers such as Richard King, Mifflin Kenedy, and Charles Stillman. The steamboats dominated river trade, transporting goods from several stops such as El Capote as far upriver as Rio Grande City and downriver to Brownsville (Graf 1942:27; Hidalgo County Historical Commission n.d.a:3). El Capote ferry joined 12 other Hidalgo County ferries such as Rosario, Agua Negra, La Blanca, and Granjeno for the second half of the nineteenth century.

El Capote was Ferry No. 6 of the Hidalgo 


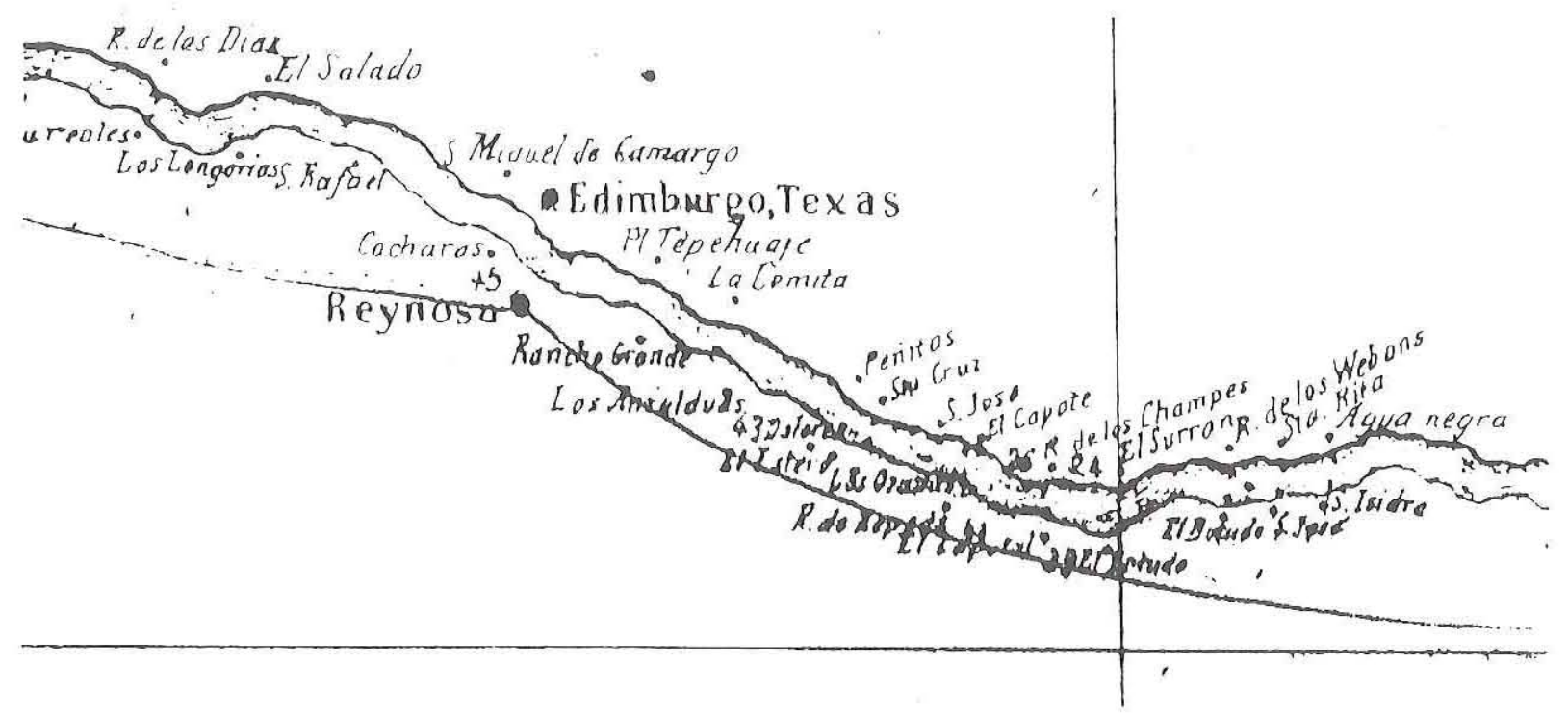

Figure 6. Map of the Lower Rio Grande Valley in the vicinity of Reynosa, Mexico, 1873 (from Comisión Pesquisidora 1874:148). This is the earliest map found that depicts the community of El Capote.

County ferries, registered as "One at the Capote Rancho. One Batteaux and Skiff. Ferry Boat to pass between Edinburg [present-day Hidalgo] and Reynosia [sic]." It was first officially licensed with the county on September 2, 1852. El Capote ferry was licensed at $\$ 2.50$ per month, although the fee decreased to $\$ 1$ per month later that year, and to only $\$ 2$ per year during the Civil War. The licensing was strictly regulated as the sheriff was ordered to "look out for" any other ferries operating without a license. The published crossing rates were set by the county for El Capote ferry not to exceed $61 / 4 \varnothing$ each person, $12 \frac{1}{2} \not \phi$ each horse and rider, $61 / 3 \notin$ each horse or mule, $50 \notin$ each cart, $12 \frac{1}{2} \phi$ each mule and cargo, $61 / 4 \phi$ each barrel of freight, $2 \notin$ each goat, sheep, or hog, $\$ 1$ each "waggon," $12 \frac{1}{2} \not$ each yoke of oxen, and $61 / 4 \notin$ all cattle each. El Capote ferry regularly paid its fees (Court Record Book A:3-18).

Family members of El Capote ranch community not only paid their county taxes and ferry license fees, but they also contributed to the official operations of the county. Members of the de la Viña family served as county judge and commissioners by the end of the nineteenth century. El Capote residents Bernardo Cantu and Luis Anaya served as Petit Jurors in 1860 . Valentin Garza served on the Grand Jury in 1867, and Tomás Garza served as the Road Commissioner for the county precinct, submitting regular reports to the county court (Court Record Book A:2, 69).

El Capote seemed to serve the social and spiritual needs of the county as well, as it provided a church, a cemetery, and assistance to runaway Black slaves in the mid nineteenth century. Blacks officially were evicted from the county at the outbreak of the Civil War when officials ordered all "free persons of color" to leave within 30 days. The Brownsville Herald reported the existence of sizable Negro colonies along the Military Road between 1836 and 1865 . And historical records suggest the existence of an underground railroad for runaway slaves at El Capote in the 1850s (Court Record Book A:48; Hidalgo County Historical Commission n.d.a:4; Hildebrand 1950: 26). Indeed, the minutes of the Methodist Episcopal Church 20th Annual Conference in 1878 indicate that the families of El Capote founded the first Protestant congregation and church in Hidalgo County as well. Variously called "El Capote Mission" and the "Jackson Ranch Church," the congregation was credited with sponsoring the establishment of other Protestant churches in the county (Hidalgo County Historical Commission n.d.a:1, 13). The congregation also maintained the cemetery known as El Capote Ranch Cemetery (41HG155) on Porción 69, near the Ramirez homestead (41HG158) (Hidalgo County Historical Commission n.d.b:1).

El Capote also played an industrial and 


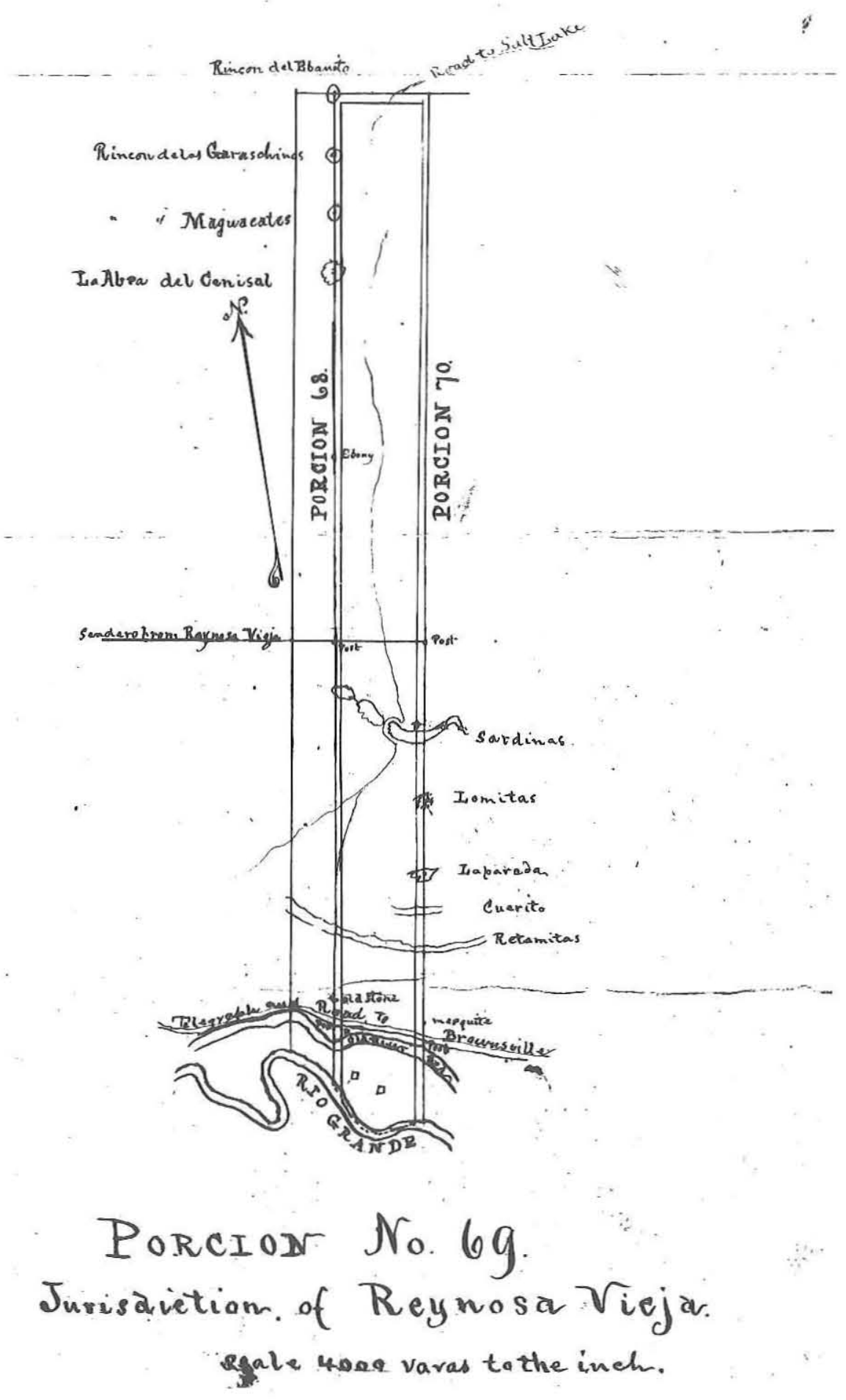

Figure 7. Porción No. 69. Jurisdiction of Reynosa Vieja. A map filed with the General Land Office on June 12, 1878, depicts structures in Porción 69 near the community of El Capote. Map courtesy of the General Land Office, Austin. 
economic role in the area by helping to introduce brickmaking to Hidalgo County. Brickmaking was a major industry in the heritage of El Capote families such as the de la Viñas and the Garzas. The de la Viña family, who lived in the vicinity of the project area, played a major role in construction of brick factories in Reynosa and brick homes in Hidalgo County. Manuel de la Viña, for example, owned the only brick home in presentday Hidalgo, which was the original site of Edinburg during the 1850 s. The county court used the home for court sessions under a rental arrangement. Other El Capote families also operated kilns in the community, and census manuscripts reveal a constant presence of bricklayers and brickmakers in the area. Indeed, a brick kiln was reported at El Capote well into the twentieth century (U.S. Bureau of the Census 1900). Pedro Guajardo, a direct descendant of one of the original families, built a brick factory (ladrillera; 41HG156) on Porción 69 near the Military Road in the 1920s. The ladrillera had a well and produced bricks primarily for sale along the Military Road (Garza and Garza 1993). In the mid twentieth century, Eduardo G. Vela appears to have built and operated a brick kiln at the same site between 1946 and 1948 .

The $1890 \mathrm{~s}$ represented something of a watershed in the history of the occupation and use of Porciones 69 and 70. To all outside appearances, control of the area was largely in the hands of Hispanic families who had occupied the land since at least the $1850 \mathrm{~s}$. It continued to be comprised primarily of cleared fields and brushy areas (Figure 8). However, dramatic changes in the ownership of adjacent porciones together with the development of new industries had practical ramifications for the project area as well. Anglo land lawyers such as Stephen Powers, James B. Wells, and Robert Kleberg had moved into position after the end of the Mexican War to take control of vast tracts of land by the 1870 s. By controlling political machines in Cameron, Starr, and Hidalgo counties, they were able to transform land ownership and economic growth for "The Valley." Wells used his political machine to move John Closner into position as Hidalgo County sheriff and political boss over Hispanic voters in 1890. Closner used the classic formula of a capitalist moving into a subsistence economy to enrich himself. As one of the few Anglos in the county, he converted his access to capital and political power to buy land in hard times from Hispanics who lacked such access in an Anglo-dominated political structure. Following a drought in the early 1890 s, Closner acquired over 45,000 acres at $25 \not$ per acre. He began to build canals and laterals and to irrigate his land using a 25horsepower centrifugal pump brought to his plantation by T. J. Hooks. Closner's political fortunes would rise and fall in the next few decades in Hidalgo County. Indeed, an audit in February 1918 later would reveal that he had embezzled $\$ 150,000$ from the schools, the county, and the irrigation district (Anders 1982:238). But in the $1890 \mathrm{~s}$, he and other speculators operated with a free hand. One of Closner's early targets was Porciones 69 and 70 owned by El Capote families.

The break-up of Ei Capote and the Juan José Hinojosa land grant is taught in a Texas history school book by Arthur J. Rubel as a classic example of land fraud. Rubel states that in 1877, parts of the porción began to pass into Anglo hands. He states that

in June of that year the sheriff of Hidalgo County sold 3,027 acres of the grant for a total cash price of $\$ 15.00$ in order to cover tax arrears. Then in May of the following year the Hidalgo County sheriff sold 4,000 additional acres of delta land from the original grant, receiving a total price of $\$ 17.75$ for the 4,000 acres. In both transactions the purchasers of the lands were persons with non-Spanish surnames [Rubel 1966:36].

While Closner and his partners usurped their official positions, the Hispanic ranch families slowly descended into landless status. When the profitable crops of the fertile soils boomed as "The Magic Valley," some former ranch families were converted from landowners to a migrant labor force working the lands formerly owned by their own grandfathers. A few Hispanics had converted their lands into viable amounts of capital; moșt were not so fortunate.

Closner, on the other hand, enjoyed an apparent success from his rise as sheriff before the turn of the century. In 1898-1900, Hidalgo County Sheriff John Closner and his partner, James B. 
INTERNATIONAL(WATER)BOUNDARY COMMISSIUN

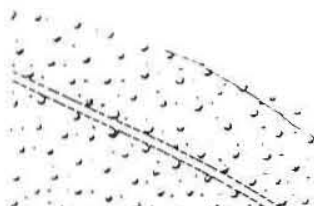

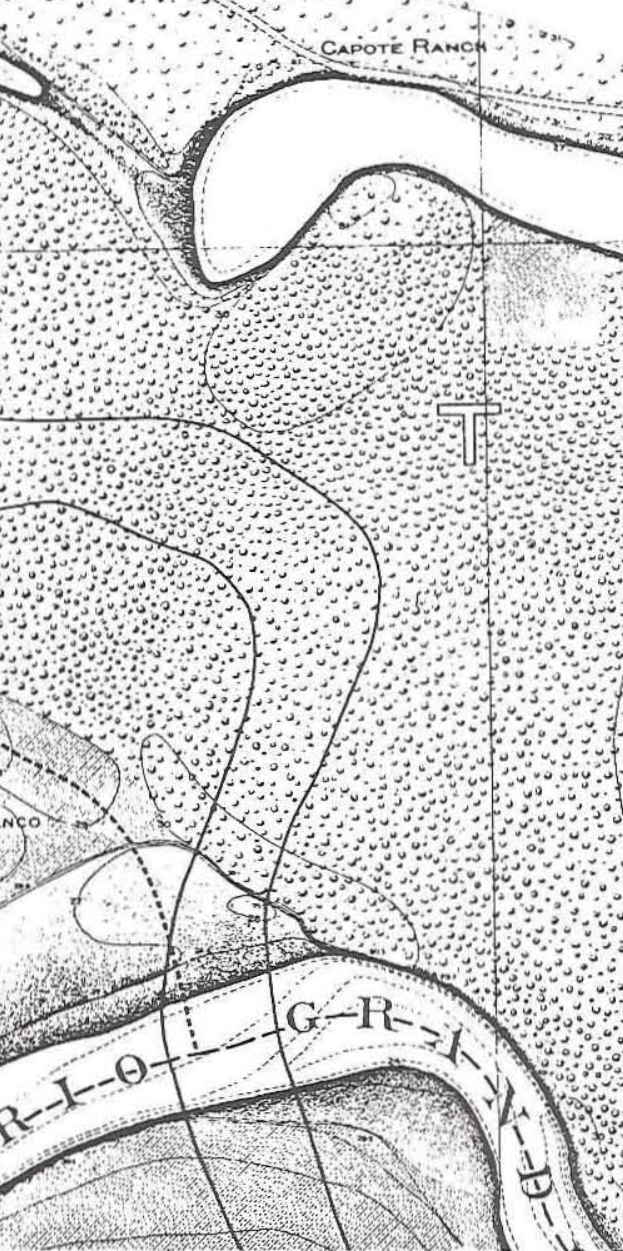

Figure 8. The southem portion of the project area in 1897. A map prepared for the Intemational Boundary Commission in 1897 (U.S. Department of State 1903:Volume 2:Sheet 34) depicts buildings and a cemetery at El Capote Ranch as well as the route of the Brownsville (Old Military) Road. 
Wells, acquired acreage including parts of Porciones 69 and 70 from members of the Garza family and other property owners (Deed Record I:56-57). In return, Closner and Wells acknowledged the title claimed by Guillermo Garza, Alejandro Garza, and Isabel Garza de Guajardo (the heirs of Valentin Garza), stating that the tract was "now, and for many years ... past, actually held, occupied and possessed by the said Guillermo Garza, and others, Heirs, of the said Valentin Garza, deceased" (Deed Record J:111-113). By the turn of the century, Wells had 100 acres in sugar cane, a crop that "dominated the final plantation era of the American south, ca. 18701920." Transferral of sugar cane technology from Louisiana, where it represented a crop of significant economic consequence, to the Lower Rio Grande Valley, where the climate was semiarid, required a "leap of technological faith" that could only be accommodated by the use of modern equipment and sophisticated irrigation systems (Farmer 1952:n.p.; Dames and Moore, Inc. 1992).

Closner played a major role in introducing sugar production to the Lower Rio Grande Valley. By winning the gold medal for his display of sugar cane at the 1904 Louisiana Purchase International Exposition, he attracted national attention and investors. Closner sold his landholdings in Porciones 69 and 70 to J. P. Withers of Kansas City, Missouri (Deed Record J:501-504), and directed his attention to increasing his sugar cane production. By 1911, Closner had joined major investors H. N. Pharr and J. C. Kelly as a board director of the Louisiana-Rio Grande Canal Company. Under various financial arrangements, these investors radically changed the land use patterns of Porciones 69 and 70, particularly regarding the project area. The investors built a pumping station in the southern portion of the town of Hidalgo and began the construction of canals. One of the laterals was Lateral A, which runs through the project area immediately north of the Old Military Road. Lateral A construction began in 1910 and was completed by 1911 (Deed Record 20:476-478). Under a previous partnership arrangement, Kelly and Pharr also had hired engineer E. B. Gore to survey and subdivide Porciones 69 and 70 north of the Old Military Road. On July 26, 1909, Kelly and Pharr filed a subdivision plat of the porciones with the Hidalgo County Clerk (Deed Record 3:133; The Pharr
Press, February 13, 1959:Section 2:1) (Figure 9). This tract, known as the Kelly-Pharr subdivision, shaped the future of the old porciones north of Lateral A in sharp contrast to that of El Capote in the project area south of the canal (Figure 10).

To the north of Lateral A, small farms of 20 to 40 acres were cleared of brush and sold to the numerous Midwestern and Northern farmers who had been brought to the area by land companies, the railroads, and other promoters. Between 1910 and 1920 , the area used for farming in Hidalgo County increased from 8,940 to 74,168 acres; by 1924 that amount had increased to 127,220 acres. According to Hawker et al. (1929:34-47), "the increased cultivated area chiefly resulted in small tracts, resulted from .... the establishment of farms in areas subject to irrigation." These tracts were "operated by people chiefly from the Northern and West-Central States," and their frame, brick, and stucco bungalows could be seen throughout the southern portion of Hidalgo County. Their major crops were corn, cotton, and citrus fruits, which used irrigation to convert the area into the famous "Magic Valley." In contrast, the land in the portion of the project area between the Rio Grande and Lateral A of the Louisiana-Rio Grande Canal system was still held in substantial amounts of several hundreds of acres by members of the Garza and Ramirez families in 1911-1913. With limited access to capital, these families rarely participated in the economic transformation that surrounded them.

The demand for productive soils meant that irrigated uplands and bottomlands were at a premium, and between 1920 and World War II, pressure increased on older property owners to sell. In the project area, Guillermo Garza, Sr., whose family had lived at El Capote since at least the mid nineteenth century, had sold some small acreages to children, other relatives, and neighbors. As a result, the El Capote community continued and included a brick factory, store, coffin-making business, cemetery, school, and numerous homes on small farm tracts (Garza et al. 1992). However, age and lucrative offers apparently proved too tempting, and in 1928 Guillermo Garza, Sr., and his wife, Manuella Gomez de la Garza, sold most of their land to A. A. Highbarger (Deed Record 275:556), who also purchased some adjoining tracts. One small 2.45-acre site remained in Garza hands for many years, however. The 


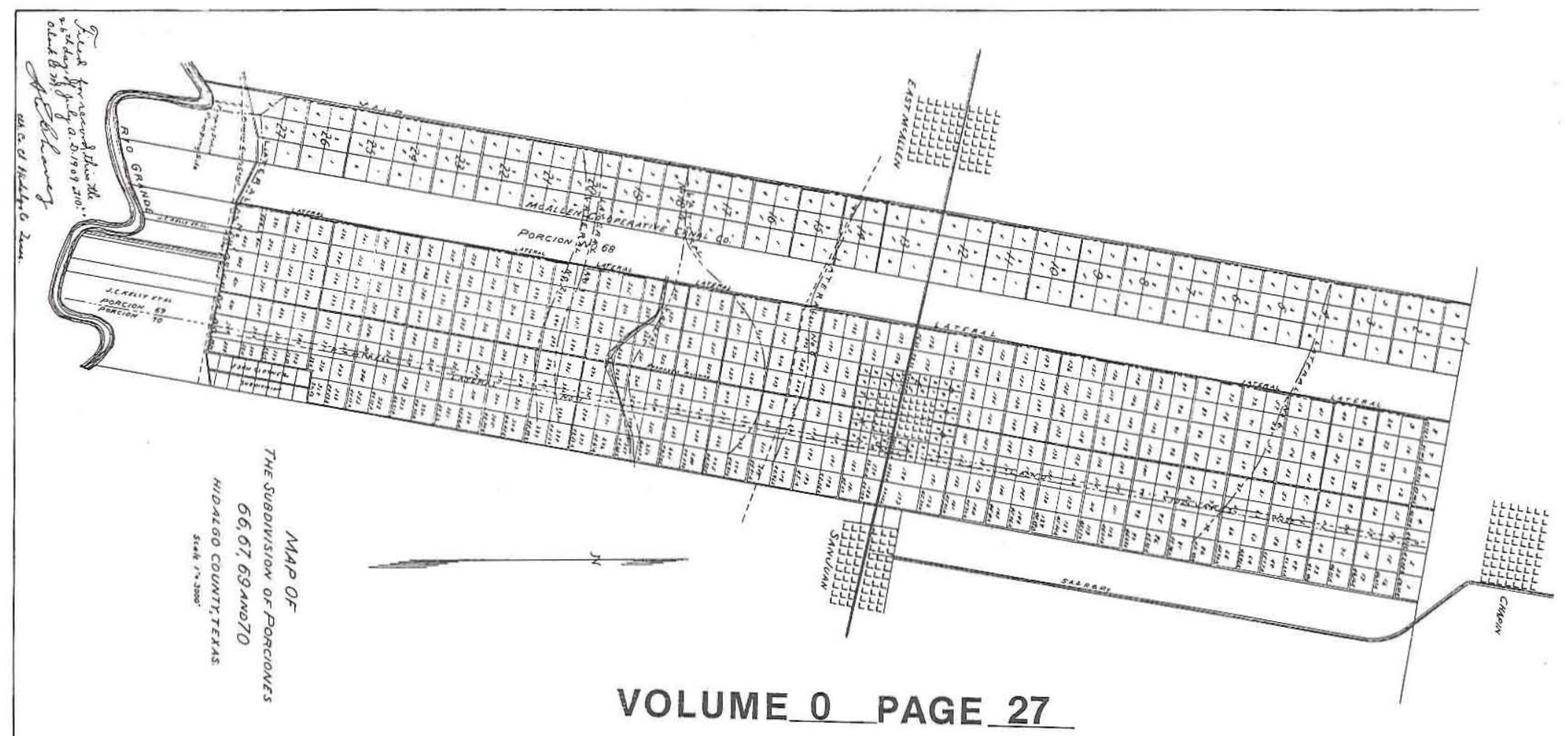

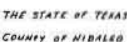

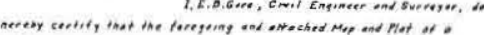

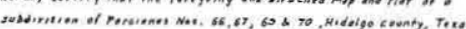

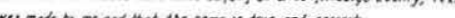

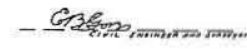

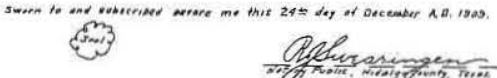

Figure 9. Map of the subdivision of Porciones 66, 67, 69, and 70, Hidalgo County, Texas, 1909. John C. Kelly and Associates' subdivision overlaid much of the present-day project area. Map from Plat Record O:27. 


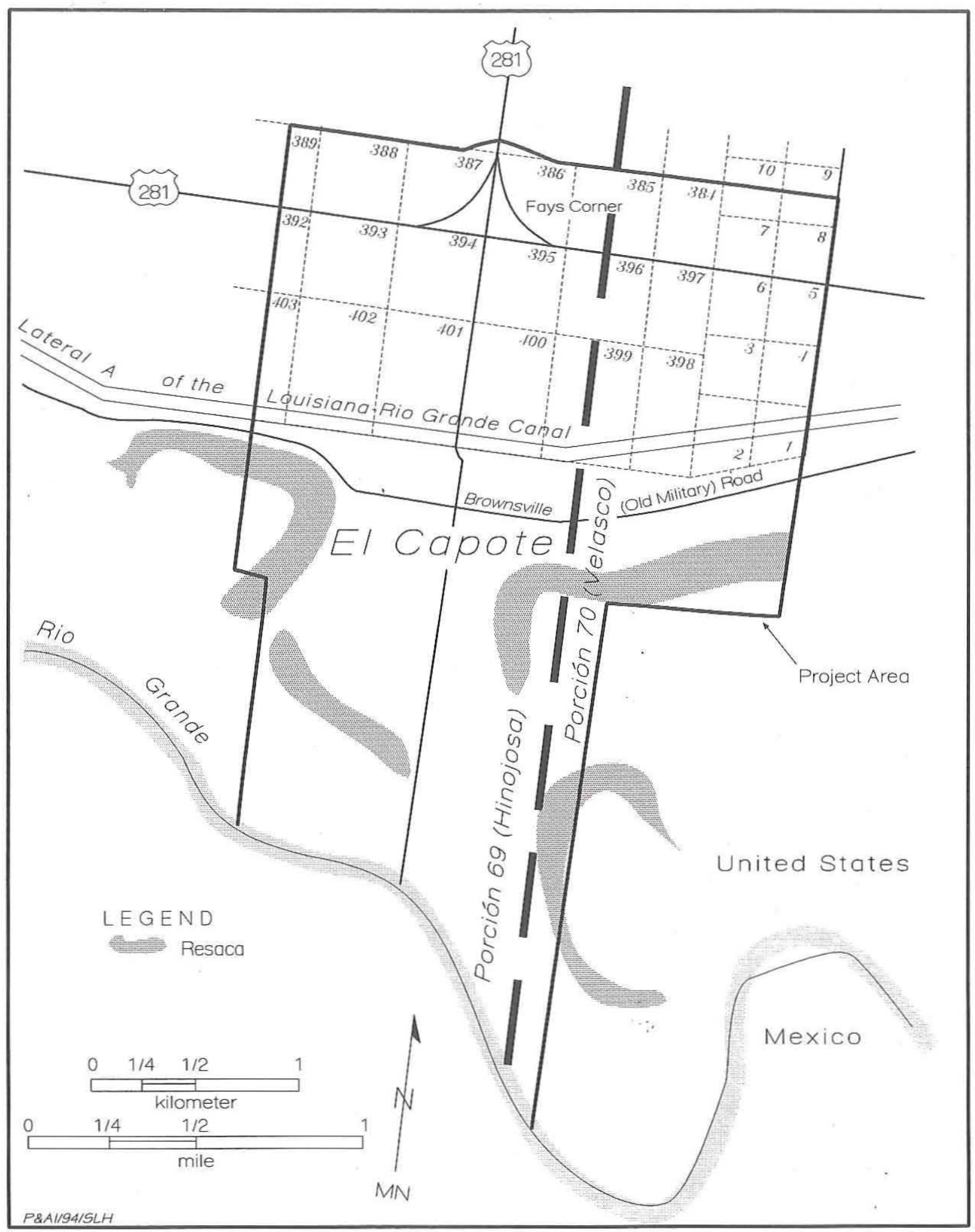

Figure 10. The project area after 1909. Land south of Lateral A of the Louisiana-Rio Grande Canal System was held in substantial acreages by residents of El Capote Ranch community, while that north of the Lateral had been subdivided into small farms and promoted to Midwestern and Northern agriculturalists. 
surrounding land eventually was sold to the Eduardo G. Vela Estate (Deed Record 499:372), but Nestor Garza paid taxes on the small plot until 1963, when he discontinued payment. Then his sons, Ruben C., Ramon V., and Guillermo, finally sold the 2.45-acre tract to Eduardo G. Vela for $\$ 1,000$ on January 9, 1964 . Vela's widow, Francisca Recio Vela, now owns the site and the surrounding land as well (Deed Record 1079:225; Tax Records).

In the first half of the twentieth century, El Capote was a large ranch complex scattered along the Old Military Road, and it is depicted on International Boundary Commission maps of 1911 (Figure 11) and 1926-1927 (Figure 12). However, the expansion of agriculture following World War II has destroyed much of the former community, and a cemetery, a brick kiln, and a few houses are all that remain today. Local informants have identified numerous housesites in the project area, including those of Guillermo Garza, Sr. (41HG153); his sons, Guillermo, Jr. (unrecorded Garza Ranch No. 2), José (41HG164), and Tirso (41HG166); and his grandsons, Roberto Garza and Nestor Garza, Jr. (41HG165). Roberto and Nestor both reportedly had large casas de leña de reboque with thatched roofs. Amado Lozano also had a nearby home (41HG167) made of board and batten, or madera parada, as well as a small store. And Pedro Guajardo built a board-and-batten home and store on the site around 1923. He also built a brick factory (41HG156) which operated until around 1922. The brick factory (ladrillera) and the land on which it was located belonged to Guajardo, a direct descendant of one of the original families. Guajardo was an uncle of Roberto and Nestor Garza, recent owners of the site. The ladrillera had a well and produced bricks primarily for sale along the Military Road (Garza and Garza 1993).

Eduardo Vela reportedly operated a brick factory on the same property between 1946 and 1948 and apparently rebuilt Guajardo's old kiln. With an area of about $10 \times 12 \mathrm{ft}$, the kiln employed five or six men and utilized mesquite wood for fuel. The bricks were intended primarily for ranch use. There are no tax records for the kiln because the bricks produced on the ranch were not marketed commercially, but they reportedly were used to build one house in Pharr and one in Hidalgo (Vela 1993).

A 380-acre tract in the Porción 69 part of El
Capote was purchased by Wyan Nelson of the Nelson Mortgage Company of Kansas City in the 1920s. After his death, Nelson's trustees, French L. Nelson, Arthur W. Nelson, and Thomas W. Nelson, obtained a warranty deed of transfer to the 380 acres in 1940 (Deed Record 467:403); they then sold it to Eduardo G. Vela for $\$ 4,612$ in 1942 (Deed Record 499:372). The large plot was renamed "El Peso" by Vela, reportedly because he found a silver peso when he dug a well on the property (Vela 1993). Vela's widow, Francisca Recio Vela, is the present trustee and owner of the 380 -acre plot and leases it to a farmer (Tax Records).

Meanwhile, in the eastern portion of the project area, the heirs of Manuel Ramirez lost their homestead at site 41HG158. According to local informants (Dyer and Norton 1992; Garza et al. 1992), one of whom has an 1883-date brick from the site, $41 \mathrm{HG} 158$ was the location of a rectangular brick house occupied by the Ramirez family. This was the Ramirez house until the family fell into arrears on taxes and sold the surrounding 220 acres to Fred W. Turner of Weslaco in 1940 (Deed Record 475:490). According to Olivia Ramirez, a granddaughter of Manuel Ramirez and one-time occupant of the house, the building was made of handmade brick and had a gable roof of wood shingles (tejamanil). Constructed in 1883, it had a main room about $15 \mathrm{ft}$ wide and twice as long, a kitchen with a fireplace (chimenea) and a six-plate wood-burning stove, a small living room (salita), and a bedroom with three beds (Ramirez et al. 1993). Other local residents described the home as having functioned as a store. The construction was described as including carved vigas of cypress and ornate ironwork at the windows (Dyer and Norton 1992). The house was in ruins for many years and finally was demolished around 1980 and the site was leveled. Turner and his wife, Pauline M. Turner, sold the 220 acres to Roy W. Barnes with a deed record that added that "said above tract is also sometimes known as El Capote Ranch" (Deed Record 510:31). The Barneses then deeded the tract over to their sons, Jack L. and Randall Lance, who now rent it to Elmo Stone (Deed Record 1358:737; Ramirez et al. 1993).

The community of El Capote continued well into the twentieth century, but World War II drew away a generation of young men who moved from family farms to urban areas. Some, such as 


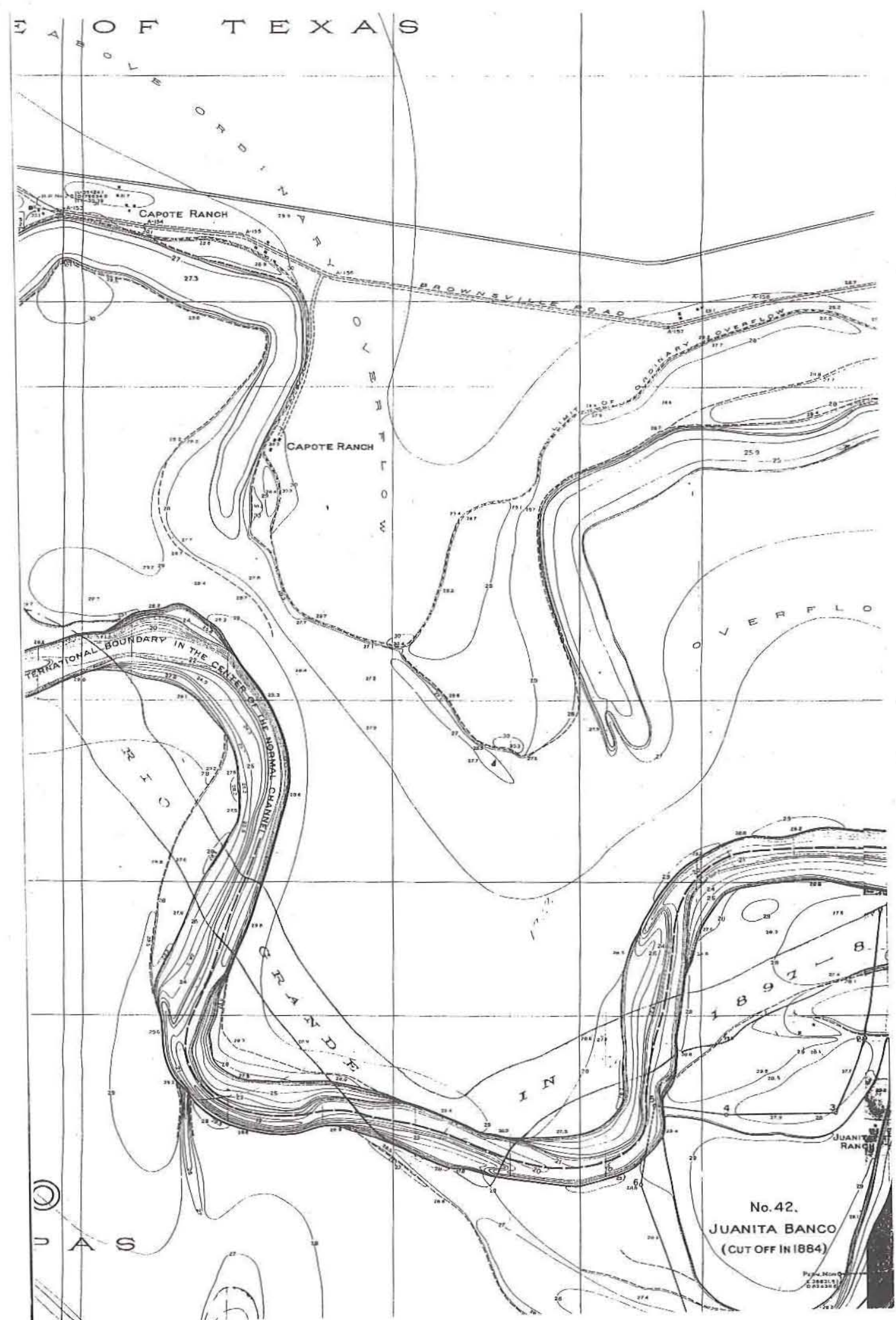

Figure 11. The project area in 1911. This section of an International Boundary Commission map prepared in February 1911 (U.S. Department of State 1913:Sheet No. 14) depicts a number of components of El Capote Ranch community. 


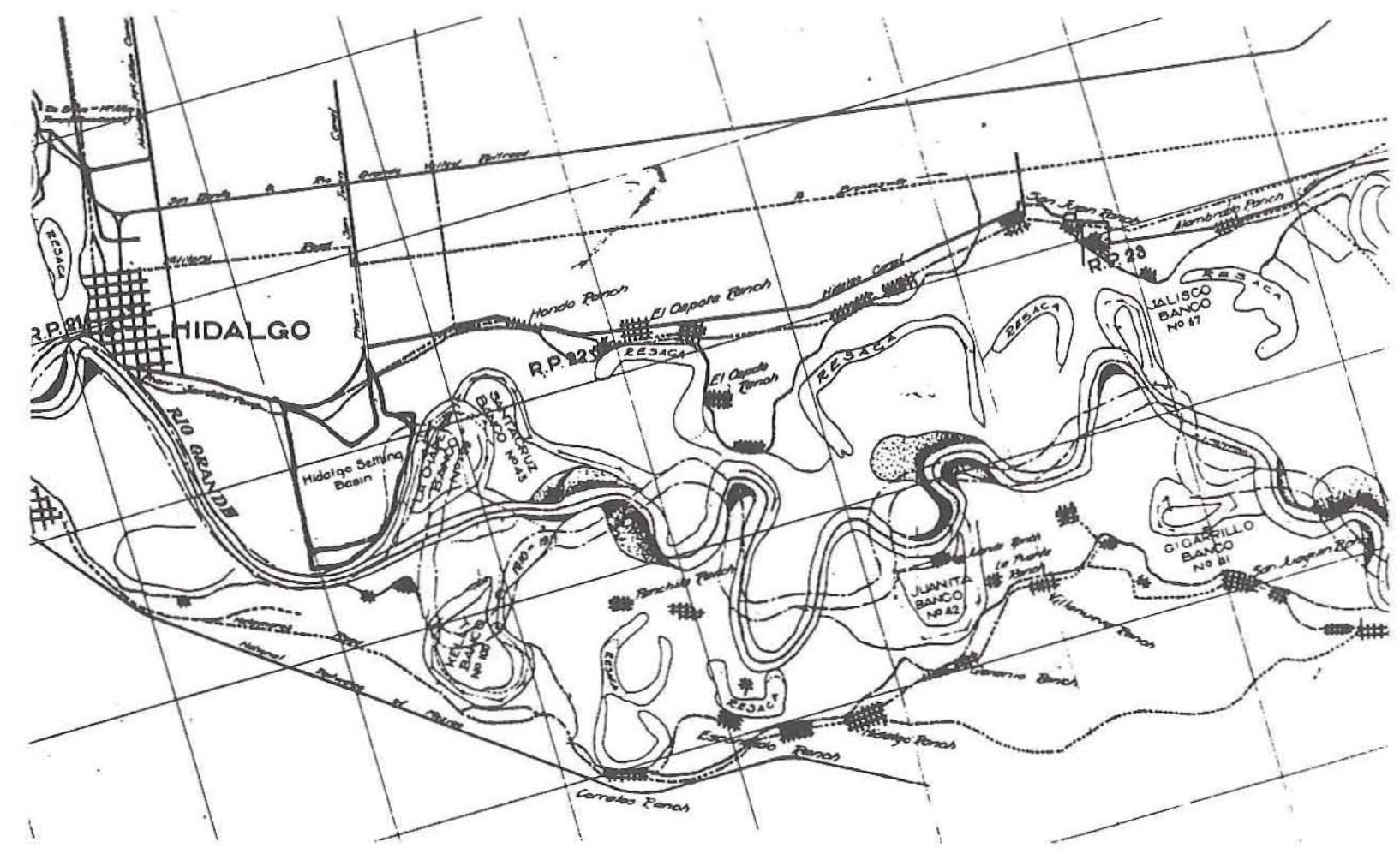

Figure 12. The project vicinity in 1926-1927. This section of an International Boundary Commission map prepared in 1926-1927 (U.S. Department of State 1929) shows the Rio Grande south of Hidalgo and depicts components of El Capote Ranch.

Roberto and Nestor Garza, used their land sale proceeds to buy a truck to work as labor contractors for the migrants who went to work picking cotton and packing citrus fruit (Garza and Garza
1993). By the 1950s, the use and appearance of the land divided by Lateral $A$ had become integrated as larger-scale truck and cotton farming dominated the agricultural landscape. 


\section{RESULTS OF THE SURVEY}

Douglas K. Boyd, Amy C. Earls, and Andrés Tijerina

This chapter is divided into two parts - one that presents the results of the additional survey of historic site locations within the area of potential effects, and a second that deals with known and suspected historic sites that are adjacent to the area of potential effects. The project area is defined as the area contained within the City of Pharr and General Services Administration jurisdictions (see Figure 1). The area of potential effects, however, is defined as the project area minus all Fish and Wildlife Service lands. Fish and Wildlife Service lands within the City of Pharr and General Services Administration juristictions are excluded from the area of potential effects since they will not be subject to any direct or secondary impacts related to the construction of the Pharr-Reynosa International Bridge, and no archeological work was done on their lands.

The archeological survey within the area of potential effects was aimed specifically at locations of suspected historic sites identified through oral histories and study of aerial photographs and historic maps. Seven historic sites were identified and documented (Figure 13). Individual site descriptions are presented in the first section of this chapter, along with an assessment of each site's historic research potential. Outside the area of potential effects, several important historic resources related to the former community of El Capote are known or suspected to exist (Figure 14). The second section of this chapter describes one recorded historic site and discusses three suspected historic site locations that are adjacent to the area of potential effects.

\section{RECORDED SITES IN THE AREA OF POTENTIAL EFFECTS}

The locations of eight housesites previously identified through informant interviews and on historic maps were field checked during the Phase II study. Specific locations that were to be investigated were the possible housesites of Tirso Garza, Amado Lozano, Luca Gonzales No. 1, Luca Gonzales No. 2, Carlos Casares, Marinoff, Joe M. Garza, and Nestor and Roberto Garza. Prior to the fieldwork, 1939 USDA-ASCS aerial photographs were reviewed, and structures were evident at or near the locations given by informants for all of these possible housesites except for Luca Gonzales No. 1. Subsequent field investigations revealed archeological evidence indicative of historic occupations at six of the locations, resulting in the recording of sites 41HG162 (Marinoff), 41HG163 (Luca Gonzales. No. 2), 41HG164 (Joe M. Garza), 41HG165 (Nestor and Roberto Garza), 41HG166 (Tirso Garza), and 41HG167 (Amado Lozano). The Carlos Casares Housesite was found to be at the eastern end of the area previously defined as 41 HG158 (discussed below). No physical evidence of the Luca Gonzales Housesite No. 1 (reported to be a jacal) was encountered at the location revealed by the informant, and no evidence of structures at this location was observed on the 1939 aerial photograph. If the informant's location is correct, then there is simply no evidence of the 
Figure 13. Map of the project area showing the locations of newly documented historic sites and previously recorded sites within the area of potential effects. 


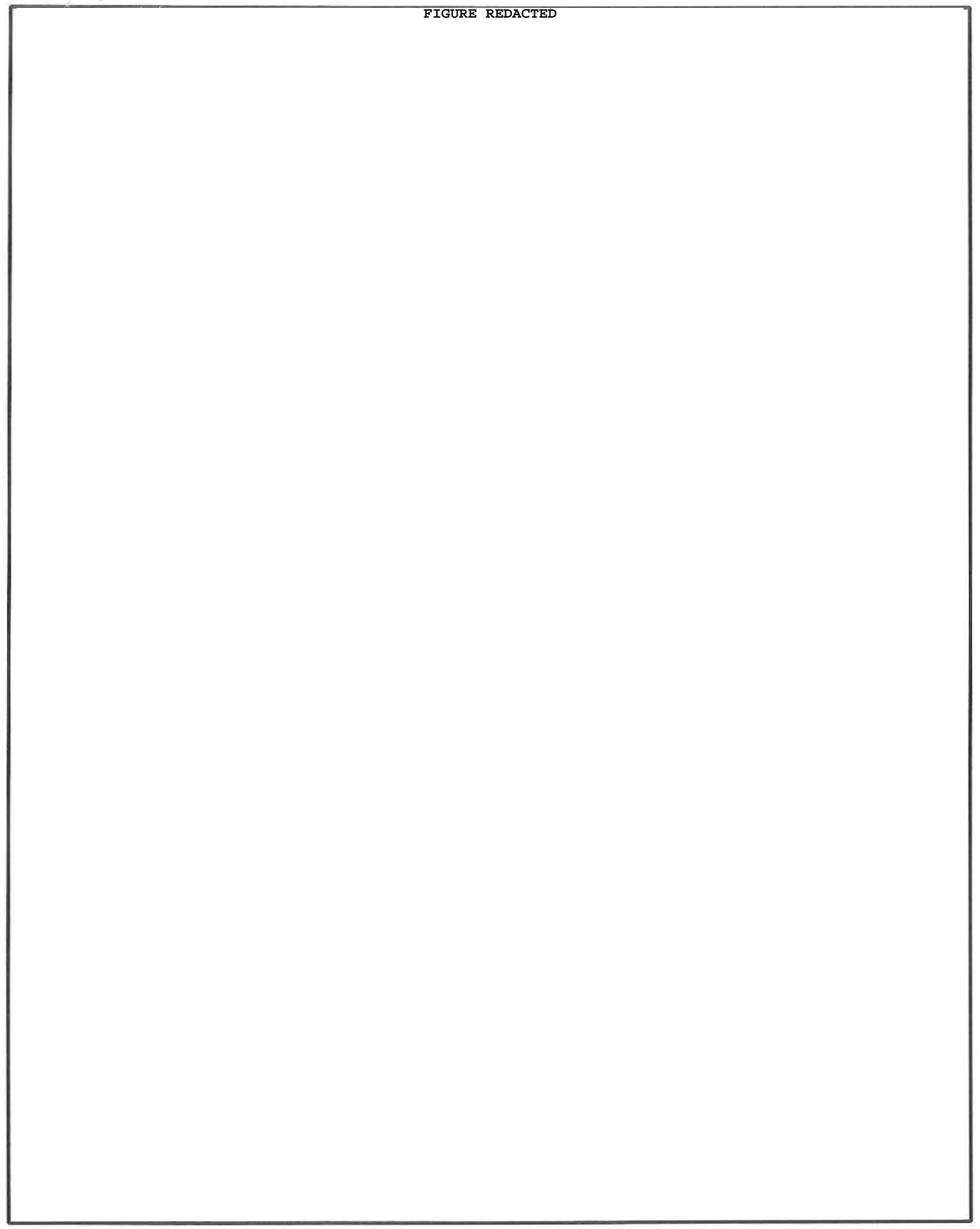

Figure 14. Map of the project area showing locations of known and suspected historic sites outside the area of potential effects. 
existence of this housesite. Alternatively, the 1939 aerial photograph (see Figure 4) shows a structure in the vicinity of the western end of 41HG158 (see Chapter 6), and it possible that this is the housesite that was remembered.

During the Phase II investigations, two additional historic housesite locations in the area of potential effects were revealed by archival research, informant interviews, and/or airphoto studies. Field checking of one of these locations, the Pedro Guajardo Ranch, revealed no physical evidence of its existence. The Pedro Guajardo Ranch was reported by one informant (Ramirez et al. 1993) to be in the active floodplain very near the Rio Grande, suggesting that if the site once existed it probably was destroyed by flooding. Survey of the second location, Anaqual Ranch, did produce evidence of a former housesite, and it was documented as $41 \mathrm{HG} 168$.

\section{Site 41HG162 (Marinoff Housesite)}

\section{Description}

Site $41 \mathrm{HG} 162$ is an historic housesite in a flat agricultural field within a featureless alluvial plain (see Figure 13). The field is currently fallow with a moderate growth of scrub vegetation. The site is immediately west of the north-south gravel road that meets U.S. Highway 281 at Fays Corner and is $300 \mathrm{~m}$ north of the irrigation canal (Lateral A). It is within the Pharr-Reynosa International Bridge right-of-way, at $96 \mathrm{ft}$ above mean sea level. The site covers an area of $90 \mathrm{~m}$ north-south by $100 \mathrm{~m}$ east-west and consists of a low-density surface scatter of historic artifacts that is most concentrated in two areas - the west-central and central portions of the site-designated as Areas A and B, respectively. No definitive evidence of structures or features was observed, but the presence of scattered brick fragments in the central area and in the western portion of the site hint at the location(s) of the former structure(s). The site has been extensively disturbed by agricultural activities.

The location of $41 \mathrm{HG} 162$ was identified by informants during the Phase I investigations (Kibler and Freeman 1993:65), and it was inspected and recorded during the current project. Based on historic maps, it appears likely that a structure was built at the site between 1911 and 1939 but disappeared before 1962. No structures are shown at this location on the 1911 International Boundary Commission map (see Figure 11), but one is present on a 1939 aerial photograph (see Figure 4). No structures are shown at this location on the 1962 USGS 7.5' Las Milpas quadrangle.

\section{Site History}

Site 41HG162 is located in Porción 69, a grant made to Juan José Hinojosa by the crown of Spain on October 22, 1767 (Deed Record C:586587). Hinojosa owned Porción 69 until September 3, 1794, after which owners included José Matias Cavazos, Lino Cavazos, and Rafael Anaya, who purchased the grant on April 16, 1823 (Deed Record E:560-562). Porción 69 remained in the ownership of the Anaya family and their relatives, including the Garzas and Cantus, and they were living there in the $1850 \mathrm{~s}$ when the grant was confirmed to Hinojosa, his heirs and assigns by the State Legislature (Deed Record A:304-305, C:586-587). In 1898-1900, Hidalgo County Sheriff John Closner and his partner, James B. Wells, acquired acreage including the location of 41 HG162 from members of the Garza family and other property owners (Deed Record I:56-57). Closner and Wells then sold 11,647 acres of their holdings in Porción 69 to J. P. Withers of Kansas City, Missouri, in 1902 (Deed Record J:501-504). Around 1905, most of Porción 69 was purchased by Charles Hammond, who sold a half interest to John C. Kelly of Waco, Texas, around 1907 (The Pharr Press, February 13, 1959). Hammond subsequently sold his half interest in the large holdings to $\mathrm{H}$. N. Pharr, who then became a partner of John C. Kelly. The partners hired E. B. Gore, an engineeer, to survey and subdivide the tract. On July 26, 1909; Kelly and his associates filed a subdivision plat of Porciones 69 and 70 with the Hidalgo County Clerk (Deed Record 3:133; The Pharr Press, February 13, 1959:Section 1:1, Section 2:1). The land surrounding $41 \mathrm{HG} 162$ is now known as the Kelly-Pharr Tract, of which 41 HG162 has a legal definition as Lot 401.

The Marinoff house took its name from a Russian family who lived there (Lucas 1993). It was a large wooden house that was torn down in the 1940s (Ramirez et al. 1993). T. L. Smith of Harris County sold the property to Harry and Blanche Lucas, who had moved from Missouri in 
1945. Blanche Lucas later partitioned the lot among her children, Wilber, Eva Lucas Hammond, and Patricia Louise Green. Green now lives in Brownwood, Texas, and manages the property as trustee of the Harry Lucas Estate (Deed Record 555:67-68, 1508:881; Tax Records, Kelly Pharr Tract:14485).

\section{Artifacts Observed and Collected}

A wide range of artifacts, most of which were concentrated in Areas A and B, was observed at $41 \mathrm{HG} 162$ (Table 1 ). In addition to the observed specimens recorded in the field, ceramic, glass, brick, and plastic artifacts were collected.

\section{CERAMICS}

Eleven sherds representing 10 vessels were collected from the surface of this site. Undecorated whitewares, stonewares (one with Bristol glaze), and a porcelain doll leg fragment also were observed at the site. Wares are two coarsepaste earthenware, six white earthenware, two semivitreous whiteware, and one stoneware sherds. The coarse-paste earthenwares consist of an orangeware vessel with interior and exterior colorless lead glaze and a redware jar with lug fragment and interior colorless lead glaze.

The stoneware vessel has a buff paste with dark brown Albany glaze interior and colorless lead-glazed exterior. Albany or natural clayglazed stoneware is dated in the north-central Texas area to the nineteenth century (Lebo 1991:161). The noncollected Bristol glaze stoneware, on the other hand, probably dates to the twentieth century.

Whiteware decoration types are overglaze hand painted, transfer printed, decal, molded/ painted, and overall colored slip glazes (Table 2). The hand-painted cup with the overglaze brown metallic rim band lacks a sheen but otherwise resembles copper luster and could represent a tea

\section{TABLE 1}

SURFACE ARTIFACTS OBSERVED AT 41HG162

\begin{tabular}{|c|c|c|}
\hline Area & Material Class & Number and Type of Artifact \\
\hline Area A & $\begin{array}{l}\text { Ceramic } \\
\text { Glass } \\
\text { Brick } \\
\text { Hard Plastic }\end{array}$ & $\begin{array}{l}20+\text { undecorated whiteware sherds } \\
1 \text { porcelain doll leg fragment } \\
20+\text { colorless container fragments } \\
10+\text { brown container fragments } \\
5 \text { aqua container fragments } \\
2 \text { white container fragments } \\
1 \text { cobalt blue container fragment } \\
7 \text { plain yellow fragments } \\
1 \text { amber fragment (comb?) }\end{array}$ \\
\hline Area B & $\begin{array}{l}\text { Ceramic } \\
\text { Glass } \\
\text { Brick and Tile } \\
\text { Hard Rubber }\end{array}$ & $\begin{array}{l}1 \text { undecorated whiteware sherd } \\
1 \text { stoneware sherd, cream glaze } \\
4 \text { aqua container fragments } \\
3 \text { colorless container fragments } \\
1 \text { white container fragment } \\
1 \text { milky green container fragment } \\
9+\text { large yellow brick fragments }(>10 \mathrm{~cm}) \\
30+\text { small yellow brick fragments }(<10 \mathrm{~cm}) \\
1 \text { terra cotta tile fragment } \\
1 \text { unidentified black fragment }\end{array}$ \\
\hline General & $\begin{array}{l}\text { Ceramic } \\
\text { Glass } \\
\text { Brick } \\
\text { Other }\end{array}$ & $\begin{array}{l}20+\text { undecorated whiteware sherds } \\
1 \text { stoneware sherd } \\
20+\text { container fragments (colorless are most } \\
\text { abundant, but a few are aqua, brown, } \\
\text { solarized, and purple) } \\
5 \text { small plain yellow fragments }(<10 \mathrm{~cm}) \\
1 \text { D-cell battery carbon rod }\end{array}$ \\
\hline
\end{tabular}

leaf luster pattern. This decoration type was most popular from 1880-1900 (Majewski and O'Brien 1987:160). The transfer-printed decoration is a fragmentary black pattern with a simple fencelike motif encircling the center of the saucer in a very open design. This pattern dates to the twentieth century.

The green floral decal occurs on a semivitreous whiteware saucer. This decoration type on a semivitreous ware could date as early as the late nineteenth century and into the 1950s (Majewski and O'Brien 1987:146-147). Richland Creek examples are dated from about 1890 to the 1940 s (Moir 1987a:103-106).

Floral molding and overglaze painting occur on a semivitreous cream-colored bowl rim. The molding is covered with a fugitive blue paint, and vertical stripes below the rim also were painted, 


\begin{tabular}{|l|l|l|l|}
\hline \multicolumn{4}{|c|}{ TABLE 2 } \\
\hline WHITEWARE CERAMIC DECORATION TYPES, 41HG162 \\
\hline Decoration Type & Pattern & Color & Vessel Form \\
\hline Overglaze hand painted & tea leaf luster? & brown metallic & cup \\
\hline Transfer printed & fencelike & black & saucer \\
\hline Decal & floral & green & saucer \\
\hline $\begin{array}{l}\text { Molded and overglaze } \\
\text { hand painted }\end{array}$ & floral molding & blue & bowl \\
\hline Overall glaze & Fiesta-like & $\begin{array}{l}\text { aqua } \\
\text { tan/orange } \\
\text { pink }\end{array}$ & $\begin{array}{l}\text { saucer } \\
\text { saucer } \\
\text { saucer }\end{array}$ \\
\hline
\end{tabular}

including one aqua ribbed cylindrical beverage (probably soda pop) bottle, one large brown beer bottle, one milky green cup or bowl, and one milky green plate. Very fragmentary colorless vessels are one cylindrical probable beverage bottle, one noncylindrical (square with chamfered corners?) bottle, and one bottle or jar. Three additional containers were recorded but not collected; colors are solar purple, cobalt blue, and white.

The colorless cylindrical probable beverage bottle base is

although all that remains is the matte remnant of the design.

Three whiteware vessels have all-over glazes. Glaze colors are a light aqua, tan/orange, and pink. The light aqua is lighter than the true Fiesta turquoise made by the Homer Laughlin China Co., and the other two colors do not match the colors listed for true Fiesta wares (Lehner 1988:246). The aqua and pink may be similar to pastel color Fiesta-like ceramics recovered from 1950s and later farmsteads at Richland Creek (Moir 1987a: 107). The colors probably represent imitations made by another company. Laughlin Fiesta wares date from 1936-1972 (Lehner 1988:246) and were reintroduced with a different glaze chemistry in 1986.

All of the ceramics except for the stoneware were collected from Area A, the eastern artifact concentration. Possible late nineteenth-century decoration types are the stoneware with Albany glaze from the Area B brick scatter in the center of the site, the possible tea leaf luster cup, and the floral decal on a semivitreous whiteware saucer. Remaining decoration types all date to the twentieth century. The ceramic assemblage reflects a turn-of-the-century to second quarter of the twentieth-century occupation.

\section{GLASS}

Nine fragments of kitchen glass were collected (Table 3). None of the glass is fluorescent under shortwave ultraviolet light, indicating lack of lead content. At least seven vessels are represented, marked "A [inside] H" over "6742," a symbol used by the Hazel-Atlas Glass Co., Wheeling, West 1971:239). The machinemade valve mark on this bottle may indicate 1930-1940 (Munsey 1970:41) or $1930 \mathrm{~s}-1950 \mathrm{~s}$ manufacture and is characteristic of milk bottles and wide-mouthed containers (Miller and Sullivan 1991:109). The colorless noncylindrical bottle is marked "A [inside circle] 46," a symbol used by the American Glass Works, Richmond, Virginia, and Paden City, West Virginia, between 1908 and 1935 and by the Armstrong Cork Co., Glass Division, Lancaster, Pennsylvania, between 1938 and 1969 (Toulouse 1971:23-25). The stippling embossed on the base of the brown beer bottle indicates twentiethcentury manufacture. The thickness (approximately $1 / 2$ inch) of the machinemade colorless bottle or jar base probably indicates it was manufactured during the first quarter of the twentieth century (Berge 1980:77).

Both fragments of marked glass and most of the collected glass fragments are from Area A, the west-central portion of the site containing a concentration of bricks. The brown beer bottle and colorless bottle or jar were collected from the general surface of the site, and the milky green plate is from the central portion of the site.

With the exception of the solar-purpled container, the glass colors, bottle shapes, and marks are all consistent with occupation in the second and third quarters of the twentieth century. The solar-purpled container and colorless thick bottle or jar base indicate some pre-World War I Virginia, between 1920 and 1964 (Toulouse 


\begin{tabular}{|c|c|c|}
\hline \multicolumn{3}{|c|}{ TABLE 3} \\
\hline Area & Color and Type & No. and Description \\
\hline General surface & colorless container & 1 base sherd with post base seam \\
\hline General surface & large brown beer bottle & 1 stippled base sherd with post base seam \\
\hline Area A & aqua cylindrical beverage bottle, probably soda pop & $\begin{array}{l}2 \text { body sherds; } 1 \text { marked with "TRAD . . ." } \\
\text { over "MIN O . ." }\end{array}$ \\
\hline Area A & colorless cylindrical [beverage?] bottle & $\begin{array}{l}1 \text { base sherd with post base seam and valve } \\
\text { mark; marked with "[A inside H]" over } \\
\text { " } 6742 \text { " }\end{array}$ \\
\hline Area $\mathrm{A}$ & colorless noncylindrical bottle & $\begin{array}{l}1 \text { square base sherd with chamfered } \\
\text { comers(?) and cup base seam; marked with } \\
\text { "A [inside circle] } 46 \text { " }\end{array}$ \\
\hline Area A & brown cylindrical beverage bottle, probably beer & 1 body sherd marked with "C . .." \\
\hline Area A & milky green cup/bowl & 1 base sherd \\
\hline Area B & milky green plate & 1 rim sherd with ribbed brim \\
\hline
\end{tabular}

occupation or disposal. No spatial differentiation in the distributions of the collected glass is evident.

\section{BRICKS AND TILE}

One clay tile and two brick fragments were recovered. The clay tile is a small fragment that is $29 \mathrm{~mm}$ thick and has a dusky red to very dusky red $(2.5 Y R 3 / 2$ to $2.5 / 2)$, well-vitrified glaze (hardness 7) on its interior and exterior surfaces. The reddish brown matrix (2.5YR $5 / 4$ to $6 / 4$ ) is a mixture of fine clay with abundant angular rock and/or grog fragments. This fragment has a very slight curvature and is probably a decorative tile (e.g., a roofing tile).

One brick fragment (approximately one-half) is a hand-molded, sand-struck, soft-mud brick that has been badly plow damaged. The brick is $160+\mathrm{mm}$ long, 99-100 mm wide, and 53-56 mm thick. It has a rough struck face, while the other surfaces are smooth with a sandy texture. The fine sandy, slightly porous matrix is buff colored and is very consistent with no obvious inclusions. It is fairly soft (i.e., hardness 3-4), and the edges are rounded. This specimen is quite similar to other handmade bricks recovered from the nearby brick factory (Types 2, 6, and 7 at 41HG156, see
Chapter 6 and Appendix B) and from other $\mathrm{El}$ Capote housesites (e.g., 41HG158).

The other brick fragment (approximately onehalf) is easily identified as a machinemade, drypressed brick. It is $110+\mathrm{mm}$ long, $115 \mathrm{~mm}$ wide, and tapers from $68 \mathrm{~mm}$ thick along one side to 54 $\mathrm{mm}$ thick along the other. Except for some plow damage, all of the surfaces are very flat and smooth, and the corners and edges are quite sharp. The brick is very hard (i.e., hardness 6-7), and its matrix and surface color is white to very pale brown (10YR $8 / 2$ to $8 / 3)$. The matrix texture is very coarse, being composed of fine clay with a very large amount of fine to coarse angular fragments of clay and/or grog. There are no perforations on the fragment, and there probably were none on the complete specimen. There is a small, circular (19-mm-diameter), slightly damaged lug on one face and a circular (17-mmdiameter) impression directly opposite it on the other face. Obviously, the lug on one brick would fit neatly into the impression on another when they were stacked or laid face to face. The lugs would have served to space the bricks apart during firing but also may indicate that this is a paving brick since these often rely on lugs for proper spacing when laid (Gurcke 1987:Figure 25). 


\section{OTHER MATERIALS}

Two additional artifacts were collected. One is a medium blue plastic button fragment with a corroded attachment at the central break. The button is saucer shaped with a flat rather than concave top and is approximately 0.7 inch in diameter. The other artifact is a translucent cobalt to milky blue glass marble. The marble is perfectly round except for chips from plowing and is 0.6 inch in diameter. This marble type dates to the twentieth century, probably the mid 1930 s to the present (Randall n.d.).

\section{SUMMARY}

The ceramic assemblage reflects occupation dating from the turn of the century to the second quarter of the twentieth century. The glass assemblage primarily dates to the second and third quarters of the twentieth century, with pre-World War I occupation indicated by a solar-purpled container. The plastic button and glass marble represent post-World War I twentieth-century occupation.

\section{Assessment}

It is recommended that site $41 \mathrm{HG} 162$ be considered ineligible for listing on the National Register of Historic Places and for designation as a State Archeological Landmark. Occupation of this site apparently dates to the first half of the twentieth century, but no structures or features are present, and it is unlikely that any buried features or cultural deposits remain intact. The site consists solely of a surficial artifact scatter that has been severely disturbed by agricultural activities. Due to its lack of archeological integrity, the site does not appear to have the potential to address important research questions.

\section{Site 41HG163 (Luca Gonzales Housesite No. 2) \\ Description}

Site $41 \mathrm{HG} 163$ is an historic housesite in a flat agricultural field within a featureless alluvial plain (see Figure 13). The field, formerly planted in cotton, had been plowed recently, and there was no vegetation cover at the time of recording. The site is less than $50 \mathrm{~m}$ north of the irrigation canal (Lateral A) and is immediately east of the northsouth gravel road that extends from the canal to Fays Corner. It is within the Pharr-Reynosa International Bridge right-of-way, at $96-97 \mathrm{ft}$ above mean sea level.

The site covers an area of $120 \mathrm{~m}$ north-south by $85 \mathrm{~m}$ east-west and consists of a low-density surface scatter of historic artifacts. No evidence of any structures or features was observed, and the site is extensively disturbed by agricultural activities.

Site 41HG163 was inspected and recorded during the current project, but its location initially was identified by informants during the Phase I investigations (Kibler and Freeman 1993:65). Historic maps indicate that a structure was built at the site between 1911 and 1939 but disappeared before 1962. No structures are shown at this location on the 1911 International Boundary Commission map (see Figure 11), but one is present on a 1939 aerial photograph (see Figure 4). No structures are shown at this location on the 1962 USGS 7.5.' Las Milpas quadrangle.

\section{Site History}

Site 41HG163 is located in the Juan Jose Hinojosa Porción 69, a grant made by the crown of Spain on October 22, 1767 (Deed Record C:586587). Porción 69 was held by Hinojosa until September 3, 1794, after which owners included José Matias Cavazos, Lino Cavazos, and Rafael Anaya, who purchased the grant on April 16, 1823 (Deed Record E:560-562). The Anaya family and their relatives, including the Garzas and Cantus, were living there in the 1850 s when the State Legislature confirmed the grant to Hinojosa, his heirs and assigns (Deed Record A:304-305, C:586-587). Hidalgo County Sheriff John Closner and his partner, James B. Wells, acquired acreage including the present-day location of $41 \mathrm{HG} 163$ from members of the Garza family and other property owners in 1898-1900 (Deed Record I:5657) and then sold 11,647 acres of their holdings in Porción 69 to J. P. Withers of Kansas City, Missouri, in 1902 (Deed Record J:501-504). Most of Porción 69 was purchased around 1905 by Charles Hammond, who sold a half interest to John C. Kelly of Waco, Texas, around 1907 (The Pharr 
Press, February 13, 1959). H. N. Pharr subsequently bought Hammond's half interest and then became a partner of John C. Kelly. Engineer E. B. Gore was hired by the partners to survey and subdivide the tract, and on July 26, 1909, Kelly and his associates filed a subdivision plat of Porciones 69 and 70 (see Figure 9) with the Hidalgo County Clerk (Deed Record 3:133; The Pharr Press, February 13, 1959:Section 1:1, Section $2: 1)$. Site $41 \mathrm{HG} 163$ is within Lot 400 of the Kelly-Pharr Tract (see Figure 10).

Local informants indicate that Luca Gonzalez had three houses at El Capote (Garza and Garza 1993; Ramirez et al. 1993). The oldest house, a jacal de leña with a thatched roof, was

\begin{tabular}{|l|l|}
\hline \multicolumn{2}{|c|}{ TABLE 4 } \\
\hline $\begin{array}{l}\text { Material } \\
\text { Class }\end{array}$ & Number and Type of Artifact \\
\hline Ceramic & $\begin{array}{l}3 \text { undecorated whiteware sherds } \\
1 \text { stoneware crock sherd, tan with mottled lead/clay glaze } \\
1 \text { undecorated porcelain sherd, saucer rim }\end{array}$ \\
\hline Glass & $\begin{array}{l}5 \text { colorless container fragments } \\
1 \text { colorless thick jar rim fragment } \\
1 \text { colorless threaded jar rim fragment } \\
1 \text { white cup/bowl rim fragment with molded ribbed decoration } \\
1 \text { white container fragment } \\
1 \text { embossed white container fragment }\end{array}$ \\
\hline Brick and & $\begin{array}{l}3+\text { yellow brick fragments } \\
1 \text { flat fiber-tempered tile (bathroom tile?) }\end{array}$ \\
\hline Tile & Several unmodified river cobbles $(<10 \mathrm{~cm})$ \\
\hline Shell & 1 mussel shell fragment \\
\hline Total number of specimens observed = 20+. \\
\hline
\end{tabular}
reported to be south of the canal, but its exact location was never confirmed (however, it may have been in the western end of 41HG158, see Chapter 6). Gonzalez moved north of the canal after a flood and built two board-andbatten houses that are reported to have been in the immediate vicinity of $41 \mathrm{HG} 163$. All three of the Gonzalez houses were torn down or removed in 1947 or 1948 to clear the field for planting crops.

\section{Artifacts Observed}

The surface artifact scatter at $41 \mathrm{HG} 163$ is very low density, and only a handful of specimens was observed (Table 4). Although the ceramic decoration types are not diagnostic to a specific time period and no artifacts were collected, the glass colors appear to represent a twentiethcentury assemblage and are consistent with the historic data indicating that the site was occupied no earlier than the late nineteenth century and mainly during the early twentieth century.

\section{Assessment}

It is recommended that site $41 \mathrm{HG} 163$ be considered ineligible for listing on the National

Register of Historic Places and for designation as a State Archeological Landmark. The site apparently dates to the early twentieth century, but no structures or features are present, and it is unlikely that any buried features or cultural deposits remain intact. The site consists solely of a surficial artifact scatter that has been severely disturbed by agricultural activities. Due to its lack of archeological integrity, the site does not appear to have the potential to address important research questions.

\section{Site 41HG164 (Joe M. Garza Housesite) \\ Description}

Site $41 \mathrm{HG} 164$ is an historic housesite in a recently plowed agricultural field within a flat, featureless alluvial plain (see Figure 13). The site, which was devoid of vegetation at the time of recording, is immediately south of the irrigation canal (Lateral A) and north of previously recorded site $41 \mathrm{HG} 157$, approximately $400 \mathrm{~m}$ west of the centerline of the Pharr-Reynosa International Bridge. It is at an elevation of $99-100 \mathrm{ft}$ above mean sea level.

The site covers an area $50 \mathrm{~m}$ north-south by 
$100 \mathrm{~m}$ east-west and consists of a low-density surface scatter of historic artifacts. No evidence of structures or features was observed, and the site is extensively disturbed by agricultural activities.

The location of $41 \mathrm{HG} 164$ was identified by informants during the Phase I investigations (Kibler and Freeman 1993:65), and it was inspected and recorded during the current project. Based on historic maps, it appears that a structure was built at the site between 1911 and 1939 but disappeared before 1962. Nothing is shown at this location on the 1911 International Boundary Commission map (see Figure 11), but one structure is visible on a 1939 aerial photograph (see Figure 4). No structures are shown at this location on the 1962 USGS 7.5' Las Milpas quadrangle.

\section{Site History}

Site 41 HG164 is located on land that was granted as Porción 69 to Juan José Hinojosa by the crown of Spain on October 22, 1767 (Deed Record C:586-587). Hinojosa owned the porción until September 3, 1794, when he conveyed it to José Matias Cavasos [Cavazos] (Deed Record E:560561), a resident of Reynosa. Cavasos died, and the land passed to his son, Lino, who conveyed Porción 69 to Rafael Anaya on April 16, 1823 (Deed Record E:562). Following the death of Rafael Anaya, Porción 69 passed to his heirs, one of whom, Luciano Anaya, passed his interest to a child, Luciana Anaya (Deed Record E:560-562). Another interest passed to María Aloquea Anaya de la Garza (wife of Jesus de la Garza), who had inherited from Manuel Anaya (Deed Record A:304-305). The Anayas and Garzas were living on the porción in 1852 when the grant was confirmed to the heirs and assigns of Juan José Hinojosa in February 1852 (Deed Record C:586587). The Hidalgo County sheriff and tax collector certified that the owners of Porción 69 had presented him tax receipts for the years 1852-1881 (Texas. General Land Office 1882a, 1882b), thereby affirming their legal ownership and clearing the way for the issuing of patents the same year. The site remained in the hands of the original Garza family until the twentieth century, when it finally passed into the hands of the Eduardo G. Vela Estate, which now owns it under the trusteeship of Francisca Recio Vela (Deed Record 1079:225; Tax Records).
Local informants state that Jose M. Garza, son of Guillermo Garza, Sr., was a lineal descendant of the original land grant family (Garza and Garza 1993). José lived in a board-and-batten house (casa de madera parada) and had a small store nearby on the site. The structures were leveled or moved to clear the land for farming in the 1940s (Ramirez et al. 1993).

\section{Artifacts Observed and Collected}

Ceramic, glass, and brick artifacts were collected from the site. In addition to these materials, one modified bone was observed (Table $5)$.

TABLE 5

SURFACE ARTIFACTS OBSERVED AT 41HG164

\begin{tabular}{|c|c|}
\hline $\begin{array}{l}\text { Material } \\
\text { Class }\end{array}$ & Number and Type of Artifact \\
\hline Ceramic & $\begin{array}{l}14 \text { undecorated whiteware sherds } \\
1 \text { undecorated semivitreous sherd }\end{array}$ \\
\hline Glass & $\begin{array}{l}7 \text { colorless container fragments } \\
1 \text { colorless pressed glass tumbler handle } \\
\text { fragment } \\
1 \text { colorless round bottle base fragment } \\
\text { with embossed "7" } \\
4 \text { aqua container fragments } \\
1 \text { aqua ribbed soda bottle base fragment } \\
1 \text { brown container fragment } \\
1 \text { cobalt blue container fragment } \\
1 \text { olive green container fragment }\end{array}$ \\
\hline Brick & 1 yellow fragment \\
\hline Bone & 1 cut fragment, large mammal \\
\hline
\end{tabular}

\section{CERAMICS}

Four ceramic sherds representing four different vessels were collected. In addition, undecorated white earthenware and semivitreous whiteware sherds were observed. Wares collected are one refined-paste nonwhite earthenware, one undecorated semivitreous whiteware, one vitreous whiteware, and one stoneware sherds. The refined earthenware handle has a buff to red paste and is decorated with a green exterior and white with 
green interior lead glaze. The buff stoneware jug or pitcher handle has a Bristol clay-glaze interior and an Albany-colored lead-glaze exterior probably dating to the twentieth century.

The vitreous whiteware saucer is decorated with an overglaze hand-painted thin rim band. The band is gray and may represent silver luster decoration that could stand alone or be associated with a floral decal decoration, for example.

The semivitreous whiteware plate sherd has a black-printed ". . . EAK . .." over ". . . EY" over ". . . ND" fragmentary mark from J. \& G. Meakin of Hanley, England (none of the other Meakins Alfred, Charles, or Henry - used both Hanley and England in their marks). The mark resembles their Royal Arms mark used on ironstone china, although the Royal Arms occurs on many of their marks and the letters on the fragment are all the same height, unlike published examples. (Godden 1964:427, no. 2601; Kovel and Kovel 1986:110). The printed mark with the name of the country of origin postdates the 1891 McKinley Tariff Act requiring imported goods to be so marked. J. \& G. Meakin have been makers of earthenware and ironstone ceramics at their Eagle Pottery and Eastwood Works since 1851 (Godden 1964:427).

Dating information from this very small temporally diagnostic assemblage indicates an occupation from the turn of the century and into the twentieth century.

\section{GLASS}

Three fragments of glass were collected from this site (Table 6). None fluoresce under shortwave ultraviolet light, indicating an absence of lead. At least three different vessels are represented-one solar-purpled beverage (probably liquor) bottle, one colorless beverage bottle, and one colorless multisided (octagonal?) bottle. Additional glass vessels observed but not collected are one colorless pressed glass tumbler and one each olive green, aqua, brown, and cobalt blue containers.

The solar-purpled beverage bottle has a brandy or wine finish (Fike 1987:Figure 2.12; Wilson 1981:111c), which was popular during the medicine bottle era (1860-1920). The colorless beverage bottle has a crown finish, which was patented in 1892 and became popular at the turn of the century (Berge 1980:42-43, 58). The side

\begin{tabular}{|l|l|}
\hline \multicolumn{2}{|c|}{ COLLECTED GLASS, 41HG164 } \\
\hline Color and Type & No. and Description \\
\hline $\begin{array}{l}\text { solar-purpled } \\
\text { beverage bottle }\end{array}$ & $\begin{array}{l}\text { 1 wine or brandy finish sherd with } \\
\text { side seam }\end{array}$ \\
\hline $\begin{array}{l}\text { colorless } \\
\text { multisided } \\
\text { bottle }\end{array}$ & $\begin{array}{l}\text { 1 slightly concave base sherd with } \\
\text { cup base seam and side seam; } \\
\text { marked with ". . . 3R* 6" }\end{array}$ \\
\hline $\begin{array}{l}\text { colorless } \\
\text { beverage bottle }\end{array}$ & $\begin{array}{l}\text { 1 crown finish sherd with bore } \\
\text { diameter of 0.6 inch and side seam } \\
\text { up to top but not over finish }\end{array}$ \\
\hline
\end{tabular}

seam on this bottle extends up to the top but not over the finish as would be expected for a container made in an automatic bottle machine, but a seam is present around the base of the finish, as is expected for a container made in an automatic bottle machine (Fike 1987:11; Miller and Sullivan 1991:109). Automatic bottle machines have been available since 1904 . The finish type and seam attributes are consistent with some form of machine manufacture dating to the turn of the century or World War I era. The colorless multisided bottle is marked ". . . 3R* 6 ," but the origin of this mark is unknown. The solar-purpled bottle with brandy or wine finish indicates occupation prior to World War I, and the colorless bottle with crown finish indicates turn-of-thecentury manufacture.

\section{BRICK}

A single brick fragment is too small to provide any meaningful measurements, but it does have some diagnostic attributes. Portions of its rough struck face and of a sandy textured side or end indicate that it is a hand-molded, sand-struck, soft-mud brick. The buff-colored clay matrix is very soft (i.e., hardness $3-4$ ), and it has a fine sandy, slightly porous texture. This specimen is similar to other handmade bricks recovered from the nearby brick factory (Types 2, 6, and 7 at 41HG156, see Chapter 6 and Appendix B) and from other El Capote housesites (e.g., 41HG158 and 41HG162).

\section{SUMMARY}

Both the ceramic and glass assemblages 
indicate a turn-of-the-century to twentieth-century occupation.

\section{Assessment}

It is recommended that site $41 \mathrm{HG} 164$ be considered ineligible for listing on the National Register of Historic Places and for designation as a State Archeological Landmark. Site occupation apparently dates to the early twentieth century, but no structures or features are present, and it is unlikely that any buried features or cultural deposits remain intact. The site consists solely of a surficial artifact scatter that has been severely disturbed by agricultural activities. Due to its lack of archeological integrity, the site does not appear to have the potential to address important research questions.

\section{Site 41HG165 (Nestor and Roberto Garza Housesite)}

\section{Description}

Site $41 \mathrm{HG} 165$ is an historic housesite in a recently plowed agricultural field within a flat, featureless alluvial plain (see Figure 13). The site is immediately south of the irrigation canal (Lateral A) and northwest of previously recorded site $41 \mathrm{HG} 157$, approximately $600 \mathrm{~m}$ west of the centerline of the Pharr-Reynosa International Bridge. It is at an elevation of $100 \mathrm{ft}$ above mean sea level.

The site, which was devoid of vegetation at the time of recording, covers an area $85 \mathrm{~m}$ northsouth by $200 \mathrm{~m}$ east-west and consists of a lowdensity surface scatter of historic artifacts. Artifacts are most concentrated within the northeastern quarter of the site, but no evidence of structures or features was observed. The site has been disturbed extensively by agricultural activities.

Site $41 \mathrm{HG} 165$ was inspected and recorded during the current project, but its location initially was identified by informants during the Phase I investigations (Kibler and Freeman 1993:65). Historic maps indicate that a structure was built at the site between 1911 and 1939 but disappeared before 1962. No structures are shown at this location on the 1911 International Boundary Commission map (see Figure 11), but one is present on a 1939 aerial photograph (see Figure 4). No structures are shown at this location on the 1962 USGS 7.5' Las Milpas quadrangle.

\section{Site History}

Site $41 \mathrm{HG} 165$ is located on land that was granted as Porción 69 to Juan Jose Hinojosa by the crown of Spain on October 22, 1767 (Deed Record C:586-587). Hinojosa owned the porción until September 3, 1794, when he conveyed it to José Matias Cavasos [Cavazos] (Deed Record E:560561), a resident of Reynosa. Cavasos died, and the land passed to his son, Lino, who conveyed Porción 69 to Rafael Anaya on April 16, 1823 (Deed Record E:562). Following the death of Rafael Anaya, Porción 69 passed to his heirs, one of whom, Luciano Anaya, passed his interest to a child, Luciana Anaya (D'eed Record E:560-562). Another interest passed to María Aloquea Anaya de la Garza (wife of Jesus de la Garza), who had inherited from Manuel Anaya (Deed Record A:304-305). The Anayas and Garzas were living on the porción in 1852 when the grant was confirmed to the heirs and assigns of Juan José Hinojosa in February 1852 (Deed Record C:586587). The Hidalgo County sheriff and tax collector certified that the owners of Porción 69 had presented him tax receipts for the years 1852-1881 (Texas. General Land Office 1882a, 1882b), thereby affirming their legal ownership and clearing the way for the issuing of patents the same year. The site remained in the hands of the original Garza family until the twentieth century, adjacent to a small 2.45-acre site which had remained in Garza hands. The surrounding land eventually was sold to the Eduardo G. Vela Estate (Deed Record 499:372). Nestor Garza had paid taxes on site 41HG156 until 1963, when he discontinued payment. Then his sons, Ruben C., Ramon V., and Guillermo, finally sold the 2.45acre tract to Eduardo G. Vela for $\$ 1,000$ on January 9, 1964. Vela's widow, Francisca Recio Vela, now owns site $41 \mathrm{HG} 156$ and the surrounding land as well (Deed Record 1079:225; Tax Records). Informants indicated that there was a board-and-batten house at 41HG165, and although it is unclear exactly when it was built, it apparently was torn down or moved from the site in the 1940s, probably about 1948 (Garza and Garza 1993; Ramirez et al. 1993). 


\section{Artifacts Observed and Collected}

Ceramic, glass, brick, and leather artifacts were collected from the general site. No site area surface proveniences were defined. Artifacts recorded but not collected are described in Table 7.

\section{CERAMICS}

Ten sherds representing 10 different vessels were collected from this site. Additionally, an undecorated whiteware plate, an ironstone cup rim, and porcelain sherds were observed but not collected. The ironstone sherd indicates a second half of the nineteenth century or later date. The Bristol glaze stonewares reflect turn-of-the-century or twentiethcentury manufacture (Lebo 1991:161).

Wares are four white earthenware, four semivitreous whiteware, one vitreous whiteware, and one stoneware sherds. The stoneware is buff colored with an Albany- and Bristol-colored lead-glaze exterior and an Albany-colored interior. Lebo (1991:161) dates stonewares in northcentral Texas with clay glazes of these colors to the 1890-1915 period.

Whiteware decoration types are overglaze hand painted, molded, transfer printed, decal, and stenciled (Table 8). Also present is one undecorated semivitreous whiteware cup.

Overglaze hand painting occurs in two forms: (1) a thick blue rim band possibly associated with an unknown pattern below the rim; and (2) thin perpendicular black lines on the body of a vessel of unknown form. The blue rim-banded vitreous whiteware saucer is of unknown age, but the black-lined semivitreous vessel is probably twentieth century in date.

The blue scroll transfer-printed semivitreous whiteware cup rim (Figure 15a) is a closed border design probably dating to the first half of the nineteenth century. The probable flow blue transfer-printed plate (?) dates from 1835 to 1910 (Majewski and O'Brien 1987:145; Williams 1981:ii).

\section{TABLE 7}

\section{SURFACE ARTIFACTS OBSERVED AT 41HG165}

\begin{tabular}{|c|c|}
\hline Material Class & Number and Type of Artifact \\
\hline Ceramic & $\begin{array}{l}2 \text { undecorated whiteware sherds } \\
2 \text { undecorated whiteware plate base sherds } \\
1 \text { undecorated whiteware plate rim sherd } \\
1 \text { undecorated grayish white ironstone cup rim sherd } \\
1 \text { stoneware crock neck sherd with Bristol glaze } \\
1 \text { stoneware sherd with Bristol glaze } \\
1 \text { undecorated porcelain sherd }\end{array}$ \\
\hline Glass & $\begin{array}{l}3 \text { colorless container fragments } \\
1 \text { colorless thick bottle base fragment } \\
3 \text { aqua container fragments } \\
2 \text { aqua round bottle base fragments } \\
1 \text { brown container fragment } \\
1 \text { brown bottle mouth fragment, crown finish } \\
1 \text { white container fragment } \\
1 \text { white cosmetic jar base fragment } \\
1 \text { purple medicine bottle fragment }\end{array}$ \\
\hline Metal & $\begin{array}{l}1 \text { unidentified ferrous strap } \\
1 \text { ferrous furniture handle fragment }\end{array}$ \\
\hline $\begin{array}{l}\text { Brick and } \\
\text { Tile }\end{array}$ & $\begin{array}{l}\text { Several small yellow brick fragments }(<10 \mathrm{~cm}) \\
1 \text { red clay tile with blue bands }\end{array}$ \\
\hline Shell & 1 mussel shell fragment \\
\hline Concrete & $\begin{array}{l}\text { Numerous curved concrete fragments from irrigation } \\
\text { well pipes }\end{array}$ \\
\hline Other & 1 carbon battery core \\
\hline
\end{tabular}

The floral decals occur on a whiteware saucer and a semivitreous plate or saucer (Figure 15b). This decoration type dates primarily to the twentieth century (through the second quarter), although the semivitreous example could date to the late nineteenth century (Majewski and O'Brien 1987:146-147; Moir 1987a:103-106).

The saucer with molded beads and a wavy line at the rim is a light repousse type dated to the turn of the century/World War I period or to 1890-1920 at Richland Creek (Moir 1987a:109). The stenciled cobalt blue floral design has an airbrushed blue rim (Figure 15c) and probably dates to the twentieth century.

The stoneware reflects turn-of-the century or twentieth-century manufacture, and the ironstone indicates use in the second half of the nineteenth 
TABLE 8

WHITEWARE CERAMIC DECORATION TYPES, 41HG165

\begin{tabular}{|l|l|l|l|}
\hline $\begin{array}{l}\text { Decoration } \\
\text { Type }\end{array}$ & Pattern & Color & Vessel Form \\
\hline $\begin{array}{l}\text { Overglaze } \\
\text { hand painted }\end{array}$ & $\begin{array}{l}\text { perpendicular lines } \\
\text { Molded }\end{array}$ & $\begin{array}{l}\text { blue } \\
\text { black }\end{array}$ & $\begin{array}{l}\text { saucer } \\
-\end{array}$ \\
\hline $\begin{array}{l}\text { Transfer } \\
\text { printed }\end{array}$ & scrolls & - & saucer \\
\hline Decal & floral & $\begin{array}{l}\text { blue } \\
\text { probably flow blue }\end{array}$ & $\begin{array}{l}\text { cup } \\
\text { plate? }\end{array}$ \\
\hline Stenciled & floral & $\begin{array}{l}\text { blue, red, green } \\
\text { pink and green }\end{array}$ & $\begin{array}{l}\text { saucer } \\
\text { plate or saucer }\end{array}$ \\
\hline
\end{tabular}

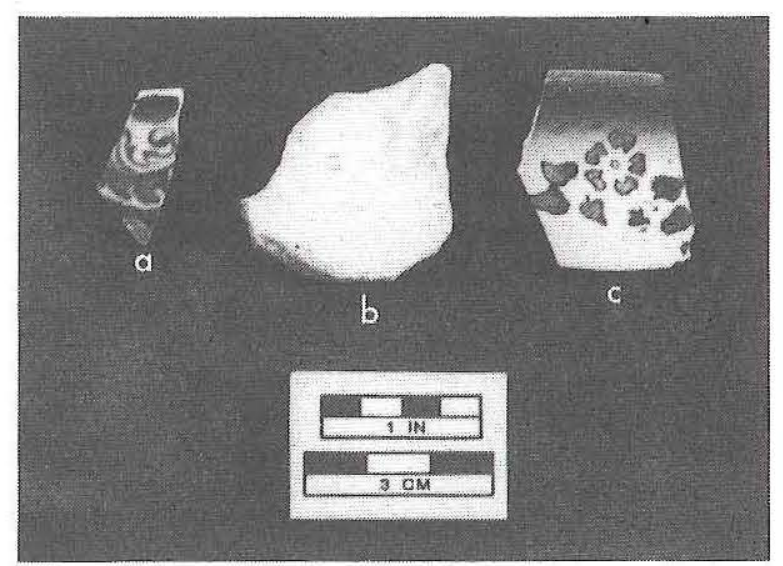

Figure 15. Decorated whitewares, 41HG165. (a) Semivitreous cup rim with transfer-printed blue scrolls; (b) semivitreous plate or saucer base with pink and green floral decal; $(c)$ stenciled and airbrushed blue floral cup rim.

century or later. Whiteware ceramic decoration types reflect nineteenth-century (floral transfer and flow blue), turn-of-the-century to World War I (molded), turn-of-the-century to second quarter of the twentieth-century (floral decals), and twentieth-century (stenciled floral and handpainted lines) occupation.

\section{GLASS}

Six fragments of container or tableware glass were collected (Table 9). None fluoresce under shortwave ultraviolet light, indicating a lack of lead content. Six vessels are represented: one olive green cylindrical bottle, one aqua cylindrical (beverage?) bottle, one aqua cylindrical beverage (soda pop?) bottle, one solar-purpled medicine bottle, one solar-purpled (beverage?) bottle, and one white cosmetic jar. Five additional vessels observed but not collected are one colorless pressed glass tumbler, one colorless medicine bottle, one colorless cylindrical bottle, one brown beverage bottle, and one cobalt blue container.

The olive green fragment probably reflects pre-Civil War manufacture, and the solarpurpled bottles reflect manufacture during the last quarter of the nineteenth century until World War I (Jones and Sullivan 1989:13). The glass indicates a possible nineteenth-century and a primary turn-of-thecentury, pre-World War I occupation.

\section{TABLE 9}

COLLECTED GLASS, 41HG165

\begin{tabular}{|l|l|}
\hline Color and Type & No. and Description \\
\hline olive green cylindrical bottle & 1 body sherd \\
\hline $\begin{array}{l}\text { aqua cylindrical beverage } \\
\text { bottle, probably soda pop }\end{array}$ & $\begin{array}{l}1 \text { thick-ribbed body } \\
\text { sherd }\end{array}$ \\
\hline $\begin{array}{l}\text { aqua cylindrical beverage(?) } \\
\text { bottle }\end{array}$ & $\begin{array}{l}1 \text { base sherd with post } \\
\text { base seam and marked } \\
\text { "O . ." }\end{array}$ \\
\hline $\begin{array}{l}\text { solar-purpled medicine } \\
\text { bottle }\end{array}$ & $\begin{array}{l}1 \text { probably rectangular } \\
\text { base sherd with } \\
\text { chamfered comers }\end{array}$ \\
\hline solar-purpled bottle & $\begin{array}{l}1 \text { slightly concave base } \\
\text { sherd }\end{array}$ \\
\hline white cosmetic jar & 1 body sherd \\
\hline
\end{tabular}

\section{BRICK}

A single brick fragment is too incomplete to provide any meaningful measurements, but it does exhibit some diagnostic attributes. It has remnants of two sandy textured surfaces (one is a face, the 
other is a side or end), and its buff-colored matrix has a fine sandy, very porous texture. Although this specimen is somewhat harder (i.e., hardness 5), it is very similar to hand-molded, sand-struck, soft-mud bricks collected from the brick factory (i.e., Types 2, 6, and 7 from 41HG156, see Chapter 6 and Appendix B) and from other El Capote housesites (e.g., 41HG158 and 41HG164).

\section{OTHER ARTIFACTS}

Other collected artifacts are a glass marble and a leather shoe fragment. The marble is machinemade transparent aqua glass with white swirls decorating the interior and exterior and with bubble inclusions. The marble has many chips removed by plowing and measures 0.6 inch in diameter. This marble type dates to the World War I to early 1930s period (Randall n.d.:7).

The tan shoe fragment is broken on three sides, with only the slightly concave fourth side showing stitch holes every $1 / 4$ inch indicating that this artifact is the anterior portion of a heel. The stitching indicates post-Civil War manufacture (Anderson 1968:62, 64), and the shoe likely dates to the twentieth century.

\section{SUMMARY}

The stoneware reflects turn-of-the-century or twentieth-century manufacture, and the ironstone indicates use in the second half of the nineteenth century or later. The whiteware ceramic decoration types reflect occupation during the nineteenth century (floral transfer and flow blue), turn of the century to World War I (molded), turn of the century to second quarter of the twentieth century (floral decals), and twentieth century (stenciled floral and hand-painted lines).

The ceramic assemblage includes transfer types dating to the nineteenth century as well as stoneware glaze and whiteware decoration types (molding, floral decals, overglaze hand painting, and stenciling) dating to the turn of the century or later. The glass assemblage reflects possible preCivil War use and primary late nineteenth-century, turn-of-the-century, and first quarter of the twentieth-century occupation. The glass marble probably was manufactured between the two world wars, and the shoe dates to the twentieth century. Overall, there is evidence for ante-bellum nineteenth-century use and a primary twentiethcentury occupation.

\section{Assessment}

It is recommended that site $41 \mathrm{HG} 165$ be considered ineligible for listing on the National Register of Historic Places and for designation as a State Archeological Landmark. The site occupation may date as early as the mid nineteenth century but is primarily twentieth century. No structures or features are present, however, and it is unlikely that any buried features or cultural deposits remain intact. The site consists solely of a surficial artifact scatter that has been severely disturbed by agricultural activities. Due to its lack of archeological integrity, the site does not appear to have the potential to address important research questions.

\section{Site 41HG166 (Tirso Garza Housesite)}

\section{Description}

Site 41 HG166 is an historic housesite in a recently plowed agricultural field within a flat, featureless alluvial plain (see Figure 13). The site is $100 \mathrm{~m}$ south of the irrigation canal (Lateral A) and immediately north of previously recorded site 41HG157. It is approximately $600 \mathrm{~m}$ west of the centerline of the Pharr-Reynosa International Bridge, at an elevation of $100 \mathrm{ft}$ above mean sea level.

The site, which was devoid of vegetation at the time of recording, covers an area $60 \mathrm{~m}$ northsouth by $45 \mathrm{~m}$ east-west and consists of a lowdensity surface scatter of historic artifacts. Artifact density is highest in the eastern half of the site, but there is no evidence of structures or features. The site has been extensively disturbed by agricultural activities.

The location of $41 \mathrm{HG} 166$ was identified by informants during the Phase I investigations (Kibler and Freeman 1993:65), and it was inspected and recorded during the current project. Based on historic maps, it appears that a structure was built at the site between 1911 and 1939 but disappeared before 1962. No structures are shown at this location on the 1911 International Boundary Commission map (see Figure 11), but one is present on a 1939 aerial photograph (see Figure 4). 
No structures are shown at this location on the 1962 USGS 7.5' Las Milpas quarangle, although three structures are shown at nearby site 41HG157.

\section{Site History}

Site $41 \mathrm{HG} 166$ is located on land that was granted as Porción 69 to Juan José Hinojosa by the crown of Spain on October 22, 1767 (Deed Record C:586-587). Hinojosa owned the porción until September 3, 1794, when he conveyed it to José Matias Cavasos [Cavazos] (Deed Record E:560561), a resident of Reynosa. Cavasos died, and the land passed to his son, Lino, who conveyed Porción 69 to Rafael Anaya on April 16, 1823 (Deed Record E:562). Following the death of Rafael Anaya, Porción 69 passed to his heirs, one of whom, Luciano Anaya, passed his interest to a child, Luciana Anaya (Deed Record E:560-562). Another interest passed to María Aloquea Anaya de la Garza (wife of Jesus de la Garza), who had inherited from Manuel Anaya (Deed Record A:304-305). The Anayas and Garzas were living on the porción in 1852 when the grant was confirmed to the heirs and assigns of Juan José Hinojosa in February 1852 (Deed Record C:586587). The Hidalgo County sheriff and tax collector certified that the owners of Porción 69 had presented him tax receipts for the years 1852-1881 (Texas. General Land Office 1882a, 1882b), thereby affirming their legal ownership and clearing the way for the issuing of patents the same year. The site remained in the hands of the original Garza family until the twentieth century, adjacent to a small 2.45-acre site which had remained in Garza hands. The surrounding land eventually was sold to the Eduardo G. Vela Estate (Deed Record 499:372). Nestor Garza had paid taxes on a site adjacent to site 41HG166 until 1963, when he discontinued payment. Then his sons, Ruben C., Ramon V., and Guillermo, finally sold the adjacent 2.45-acre tract to Eduardo G. Vela for $\$ 1,000$ on January 9, 1964 . Vela's widow, Francisca Recio Vela, now owns site 41HG166 and the surrounding land as well (Deed Record 1079:225;Tax Records).

According to local informants, 41HG166 was the site of the home of Tirso Garza, who was a lineal descendant of the original Garza family and brother of Nestor, Sr. (Garza and Garza 1993). Tirso Garza reportedly had a casa de madera parada on the site as well as a cantina, also of madera parada, nearby. Tirso's cantina may have been a separate building or it may have been in the store that his brother José ran at or near 41HG164. Tirso Garza dismantled the house in the 1950s and used the lumber to build a house along U.S. Highway 281, near the house of Olivia Ramirez, another family member of El Capote (Ramirez et al. 1993).

\section{Artifacts Observed and Collected}

Ceramic, glass, and brick artifacts were collected from the east and west portions of this site. Artifacts observed but not collected are described in Table 10.

\section{CERAMICS}

Sixteen sherds representing 14 vessels were recovered. Noncollected ceramics include undecorated whiteware plate, bowl, and cup and undecorated porcelain cup sherds, as well as a blackpainted earthenware sherd.

Coarse-paste earthenwares consist of two orange-paste vessels. One has yellow and brown bands at the interior rim, and these are covered with a green lead glaze that may represent a firing mistake. The other vessel has interior and exterior colorless lead glaze. The stonewares all have buff pastes and consist of a crock base with colorless lead glaze, a vessel with dark brown lead glaze, and a crock rim with cream-colored Bristol interior glaze and cobalt blue exterior glaze. Lebo (1991:161) dates vessels with Bristol glaze interiors and Bristol and cobalt blue exteriors in north-central Texas from 1915 to the present.

Whiteware decoration types are overglaze hand painted, decal (including one with a handpainted line), stenciled, and molded (Table 11). Also present are an undecorated semivitreous saucer and an undecorated ironstone platter.

One vitreous whiteware cup handle has traces of overglaze hand-painted blue decoration. Four vessels have floral decals. A semivitreous whiteware cup has a thin hand-painted black rim band above the blue floral remnant. Decals occur from 1890 to the 1950 s, with the polychrome decals on white earthenware (Figure 16a) in this assemblage probably dating to the first quarter of the twentieth century (cf. Majewski and O'Brien 1987:146-147; 
TABLE 10

SURFACE ARTIFACTS OBSERVED AT 41HG166

\begin{tabular}{|l|l|}
\hline Material Class & Number and Type of Artifact \\
\hline Ceramic & $\begin{array}{l}3 \text { undecorated whiteware sherds } \\
1 \text { undecorated whiteware plate base sherd } \\
1 \text { undecorated whiteware plate rim sherd } \\
1 \text { undecorated whiteware bowl base sherd } \\
4 \text { undecorated whiteware cup base sherds } \\
1 \text { undecorated whiteware cup rim sherd } \\
1 \text { undecorated porcelain cup rim } \\
1 \text { black-painted earthenware (Mexican made?) }\end{array}$ \\
\hline Glass & $\begin{array}{l}2 \text { colorless container fragments } \\
1 \text { colorless medicine bottle lip fragment } \\
2 \text { colorless lamp chimney fragments } \\
1 \text { colorless ribbed flat glass fragment } \\
1 \text { colorless ribbed bottle or tumbler fragment } \\
1 \text { colorless container fragment with embossed } \\
\text { crosshatched design } \\
2 \text { brown container fragments } \\
1 \text { aqua bottle neck fragment } \\
1 \text { aqua soda bottle fragment } \\
1 \text { cobalt blue container fragment } \\
1 \text { purple container fragment } \\
1 \text { purple continuous-thread jar lip } \\
1 \text { white container fragment } \\
1 \text { white container rim fragment }\end{array}$ \\
\hline Bonell & $\begin{array}{l}1 \text { yellow brick fragment } \\
1 \text { orange brick fragment } \\
1 \text { salmon brick fragment } \\
1 \text { unidentified tile fragment }\end{array}$ \\
\hline Concrete & $\begin{array}{l}\text { Several curved concrete fragments from } \\
\text { irrigation well pipes }\end{array}$ \\
\hline
\end{tabular}

The two molded-rim vessels have delicate, light-relief patterns similar to those illustrated for north-central Texas (Moir 1987a:109) and dating to 18901920. These types are contemporaneous with the polychrome floral decals.

No significant differences are evident in the ceramics from the east and west portions of the site. All of the color-decorated whitewares are from the west portion of the site, but these may be contemporaneous with the undecorated whitewares from the east portion. The orangewares, stonewares, and molded whitewares occur in both portions of the site. The ceramic assemblage indicates occupation during the first and second quarters of the twentieth century.

\section{GLASS}

Twenty-two fragments of container and tableware glass were collected (Table 12). None is fluorescent under shortwave ultraviolet light. At least 12 vessels are represented in the collected fragments. These are two aqua (probably beverage) bottles, two aqua medicine bottles, one colorless medicine bottle, one colorless drugstore bottle, one colorless cylindrical (food?) bottle, one colorless cylindrical (soda pop?) bottle, one colorless jar, one white saucer, one white bowl, and one cobalt blue cylindrical bottle. Also present are decorative flat glass and a lamp chimney upper rim. Two additional noncollected sherds represent one brown container and one solar-purpled jar with a continuous-thread finish.

The heel fragment of an aqua bottle has no
de seams and a pushup similar to those found on

Moir 1987a:103-106). The red decal (Figure 16b), however, occurs on a vitreous whiteware and is a bold pattern probably representing a Japanese import manufactured during the second quarter of the twentieth century. The stenciled floral saucer (Figure 16c) has distinctly outlined brown leaf veins and blurred-edge leaves and flowers that appear to have been airbrushed. These techniques indicate a twentieth-century, probably post-World War I, date. olive green wine or champagne bottles with handblown bases and could date to the first half of the nineteenth century.

The aqua beverage bottle double-beaded finish has a seam to the top but not over the finish, indicating automatic or semiautomatic machine manufacture (Fike 1987:11; Miller and Sullivan 1991:109) and a turn-of-the-century to first 
TABLE 11

WHITEWARE CERAMIC DECORATION TYPES, 41HG166

\begin{tabular}{|l|l|l|l|}
\hline Decoration Type & Pattern & Color & Vessel Form \\
\hline Overglaze hand painted & - & blue & cup \\
\hline $\begin{array}{l}\text { Decal with hand- } \\
\text { painted rim band }\end{array}$ & floral & blue and black & cup \\
\hline Decal & floral & $\begin{array}{l}\text { red } \\
\text { red and green } \\
\text { pink and green }\end{array}$ & $\begin{array}{l}\text { saucer } \\
\text { saucer or plate } \\
\text { saucer }\end{array}$ \\
\hline Stenciled & floral & green, red, brown & saucer \\
\hline Molded & $\begin{array}{l}\text { beaded with line } \\
\text { beaded with wavy } \\
\text { lines and dots }\end{array}$ & $\begin{array}{l}- \\
\text { saucer } \\
\text { bowl }\end{array}$ \\
\hline
\end{tabular}

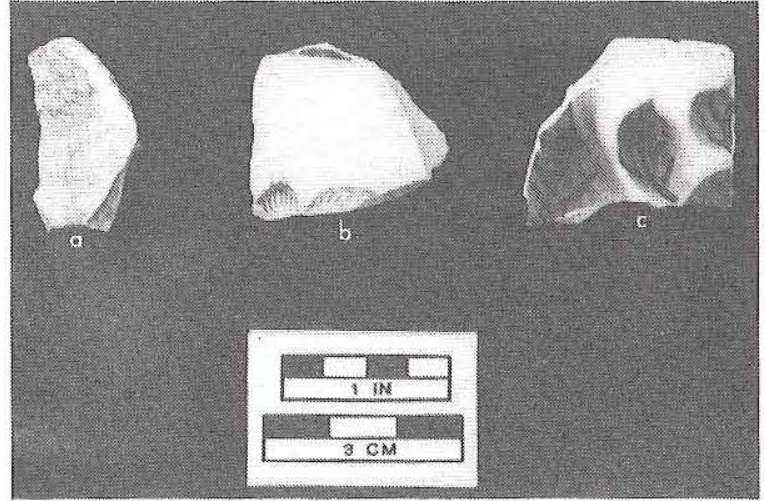

Figure 16. Decorated whitewares, 41HG166. (a) Red and green floral decal vessel sherd; $(b)$ vitreous whiteware saucer base with red floral decal; $(c)$ saucer base with green, red, and brown floral stencil.

quarter of the twentieth-century date.

The medicine bottles date to the 1860-1920 period. One of the aqua medicine bottles has a collared ring finish (Figure 17a). The other has a slightly tapered ring or oil type profile and no side or finish seams; the top of the finish is smooth, and apparently the entire finish was fire-polished, which erased the seams and caused the finish to blend in with the neck.

The colorless cylindrical (food) bottle (Figure $17 b$ ) and cobalt blue bottle, also with side seams up to the top of but not over the threaded finish, date to 1924 or later. The colorless drugstore bottle (Figure 17c) with side seam up to but not over the threaded finish probably dates to 1924 or later, when this finish type became popular (Berge 1980:43). The colorless cylindrical beverage bottle has a stippled base indicating twentieth-century manufacture.

The lamp chimney upper rim has a flared opening and templateformed or turn-molded scalloped decoration at the rim. Scalloped rims were formed in a separate mold after annealing, using a crimping machine after 1877 and semiautomatic machines from 1899 until at least the end of the 1920s. The "pearl top" design is an example of this decoration type that was patented in 1883 . Similar rim decorations were patented in 1877 and are rare in Canada before 1885 (Woodhead et al. 1984:6162). Pearl-top and similar kerosene lamp chimneys are still being made (Lewis and Haskell
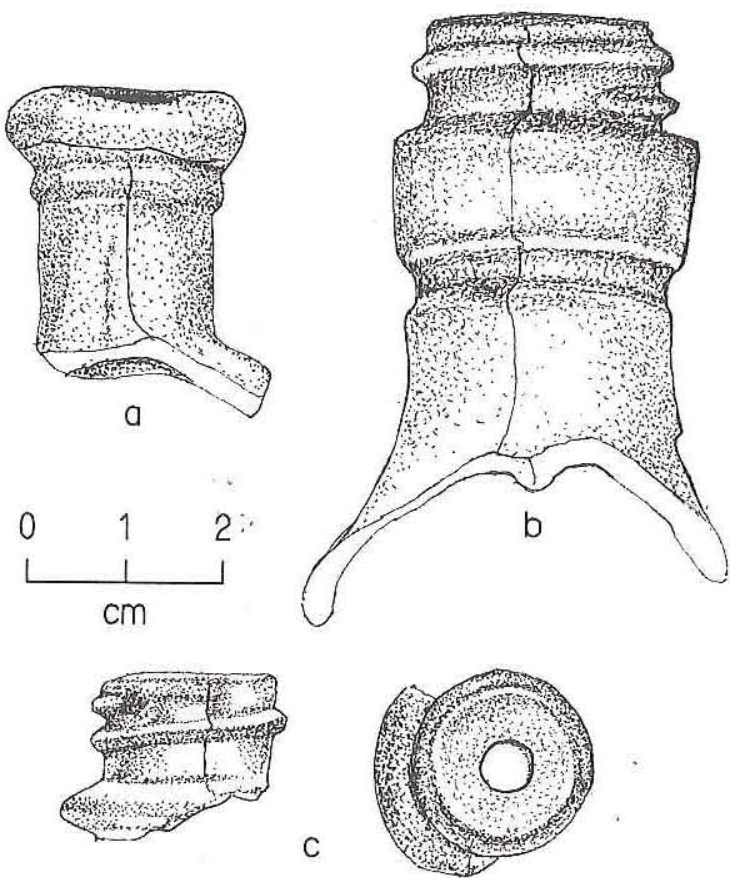

Figure 17. Bottle finishes, $41 \mathrm{HG} 166$. (a) Aqua medicine bottle with collared ring finish; $(b)$ colorless food bottle with threaded finish; $(c)$ colorless drugstore bottle with threaded finish. 


\begin{tabular}{|c|c|}
\hline & TABLE 12 \\
\hline & COLLECTED GLASS, 41HG166 \\
\hline Color and Type & No. and Description \\
\hline aqua cylindrical (beverage?) bottle & 1 heel sherd with pushup present but unknown profile and 1 body sherd \\
\hline aqua beverage bottle & $\begin{array}{l}1 \text { double-bead finish sherd with bore diameter of } 0.6 \mathrm{inch} \text {; side seam up to } \\
\text { but not over top of finish }\end{array}$ \\
\hline aqua bottle, probably beverage & 1 neck sherd with bore diameter of 0.6 inch \\
\hline aqua medicine bottle & $\begin{array}{l}1 \text { fire-polished ring or oil finish sherd and } 1 \text { neck and collared ring finish } \\
\text { sherd with bore diameter of } 0.4 \text { inch and side seam up to finish }\end{array}$ \\
\hline aqua bottle & 1 neck sherd with 0.9 -inch bore diameter below finish \\
\hline aqua flat & 1 decorative body sherd with thick-ribbed front and fine-ribbed back \\
\hline colorless cylindrical bottle & $\begin{array}{l}1 \text { base sherd with post base seam and one side seam; } 1 \text { heel sherd with post } \\
\text { base seam; and } 1 \text { body sherd marked with ". . OR" over ". . TOR" in } \\
\text { black enamel paint }\end{array}$ \\
\hline colorless cylindrical beverage(?) bottle & 1 stippled base sherd with post base seam; marked "E 159 " \\
\hline colorless cylindrical food(?) bottle & 1 neck and threaded finish sherd with side seam up to but not over finish \\
\hline colorless medicine bottle & 1 rectangular recessed base sherd with cup base seam \\
\hline colorless drugstore & $\begin{array}{l}1 \text { threaded finish sherd with } 0.2 \text {-inch opening and } 0.4 \text {-inch bore; side seam } \\
\text { up to but not over finish }\end{array}$ \\
\hline colorless bottle & 1 body sherd \\
\hline colorless jar & 1 neck and threaded finish sherd with bore diameter of ca. $7 \mathrm{~cm}$ \\
\hline colorless lamp chimney & $\begin{array}{l}1 \text { upper rim fragment; template-formed scalloped decoration at rim and flared } \\
\text { opening of ca. } 6 \mathrm{~cm}\end{array}$ \\
\hline cobalt blue cylindrical jar & 1 neck and threaded finish sherd with side seam \\
\hline cobalt blue bottle & 1 threaded finish sherd with side seam up to but not over finish \\
\hline white saucer & 1 rim sherd with molded scroll interior decoration \\
\hline white plate & $\begin{array}{l}2 \text { rim sherds; } 1 \text { with fish scales on interior and ribs on exterior; } 1 \text { foliate on } \\
\text { interior }\end{array}$ \\
\hline white bowl & 1 rim sherd with molded crosshatched decoration below rim \\
\hline
\end{tabular}

1981:119-120).

Possible nineteenth-century disposal is indicated by the aqua pushup fragment and the lamp chimney rim. Turn-of-the-century to first quarter of the twentieth-century disposal is indicated by the aqua double-beaded finish. The remaining glass containers date to the second quarter of the twentieth century or later.

\section{BRICK}

A single brick is too fragmentary to provide any meaningful measurements but does exhibit some diagnostic attributes. It is a corner fragment 
that retains parts of three smooth molded surfaces that are dark gray to reddish brown (5YR 4/1 to $4 / 3$ ) in color and are partially vitrified. The surfaces are extremely hard (i.e., hardness 8 ), and the edges are rounded and very smooth due to molding (rather than deterioration or weathering). The interior is weak red (10R $4 / 3$ to $4 / 4$ ) in color and is composed of a fine clay with abundant angular rock or grog fragments. It does not exhibit the distinctive attributes of a soft-mud brick, and it may be a stiff-mud or dry-pressed brick. This fragment may be from a paving or a fire brick, but it is too incomplete to be certain.

\section{OTHER ARTIFACTS}

Also collected were a glass marble and porcelain doll hand and lower arm. The marble is a translucent medium to milky blue, machinemade, perfectly round sphere with no chips removed and no decoration other than the irregular swirls of the matrix colors. This marble type probably dates from the mid 1930s to the present (Randall n.d.:6).

The left doll hand and lower arm is made of solid molded unglazed porcelain. This artifact is similar to illustrated examples from 1862-1894 Fort Bowie (Herskovitz 1978:Figure 62) in Arizona and from the 1875-1919 Moser farmstead in Arkansas (Stewart-Abernathy 1986:Figure 76), indicating that the date range is fourth quarter of the nineteenth century to first quarter of the twentieth century.

\section{SUMMARY}

The ceramic assemblage dates to the first half of the twentieth century. The glass assemblage is consistent with this date range but also indicates possible occupation during the first half of the nineteenth century. Other artifacts indicate possible nineteenth- and definite twentieth-century occupation.

\section{Assessment}

It is recommended that site 41HG166 be considered ineligible for listing on the National Register of Historic Places and for designation as a State Archeological Landmark. The site occupation may date as early as the first half of the nineteenth century but is primarily twentieth century. No structures or features are present, however, and it is unlikely that any buried features or cultural deposits remain intact. The site consists solely of a surficial artifact scatter that has been severely disturbed by agricultural activities. Due to its lack of archeological integrity, the site does not appear to have the potential to address important research questions.

\section{Site 41HG167 (Amado Lozano Housesite)}

\section{Description}

Site 41 HG167 is an historic housesite in a recently plowed agricultural field within a flat, featureless alluvial plain (see Figure 13). The site is $200 \mathrm{~m}$ south of the irrigation canal (Lateral A) and immediately east of previously recorded site 41HG157. It is approximately $400 \mathrm{~m}$ west of the centerline of the Pharr-Reynosa International Bridge, at an elevation of $100 \mathrm{ft}$ above mean sea level.

The site, which was devoid of vegetation at the time of recording, covers an area $80 \mathrm{~m}$ northsouth by $80 \mathrm{~m}$ east-west and consists of a lowdensity surface scatter of historic artifacts. There are no apparent concentrations of artifacts, and no evidence of structures or features was observed. The site has been disturbed extensively by agricultural activities.

Site 41HG167 was inspected and recorded during the current project, but its location initially was identified during the Phase I investigations (Kibler and Freeman 1993:65). A possible structure is depicted in the vicinity on the 1898 International Boundary Commission map (see Figure 8), but it is uncertain whether it is at 41 HG167 or at adjacent site 41HG157. Historic map data do reveal that a structure was built at the site between 1911 and 1939 but disappeared before 1962. No structures are shown at this location on the 1911 International Boundary Commission map (see Figure 11), but one is present on a 1939 aerial photograph (see Figure 4). No structures are shown at this location on the 1962 USGS 7.5' Las Milpas quadrangle.

\section{Site History}

Site 41 HG167 is located on land that was granted as Porción 69 to Juan José Hinojosa by the 
crown of Spain on October 22, 1767 (Deed Record C:586-587). Hinojosa owned the porción until September 3, 1794, when he conveyed it to José Matias Cavasos [Cavazos] (Deed Record E:560561), a resident of Reynosa. Cavasos died, and the land passed to his son, Lino, who conveyed Porción 69 to Rafael Anaya on April 16, 1823 (Deed Record E:562). Following the death of Rafael Anaya, Porción 69 passed to his heirs, one of whom, Luciano Anaya, passed his interest to a child, Luciana Anaya (Deed Record E:560-562). Another interest passed to María Aloquea Anaya de la Garza (wife of Jesus de la Garza), who had inherited from Manuel Anaya (Deed Record A:304-305). The Anayas and Garzas were living on the porción in 1852 when the grant was confirmed to the heirs and assigns of Juan José Hinojosa in February 1852 (Deed Record C:586587). The Hidalgo County sheriff and tax collector certified that the owners of Porción 69 had presented him tax receipts for the years 1852-1881 (Texas. General Land Office 1882a, 1882b), thereby affirming their legal ownership and clearing the way for the issuing of patents the same year. The Lozano, Garza, and Anaya names appear on the U.S. Census of 1880 for El Capote.

The 1.69 acres on which 41 HG167 is located remained in the hands of the original Lozano family until the twentieth century, adjacent to a small 2.45-acre site which had remained in Garza hands. The surrounding land eventually was sold to the Eduardo G. Vela Estate (Deed Record 499:372). Amado and Paula C. Lozano had paid taxes on site $41 \mathrm{HG} 167$ until 1954, when Paula discontinued payment. Then Eduardo G. Vela took over the 1.69-acre tract in 1955, according to tax records. Vela's widow, Francisca Recio Vela, now owns site 41HG167 and the surrounding land as well (Deed Record 1079:225; Tax Records).

Informants stated that Amado Lozano had a board-and-batten house (casa de madera parada) and a small store at or near 41HG167. His house apparently was torn down or moved in the 1940s (Garza and Garza 1993; Ramirez et al. 1993).

\section{Artifacts Observed and Collected}

Ceramic, glass, and plastic artifacts were collected from this site. In addition, brick, stone, concrete, plastic, and bone artifacts were observed (Table 13).

\begin{tabular}{|l|l|}
\hline \multicolumn{2}{|c|}{ TABLE 13 } \\
SURFACE ARTIFACTS OBSERVED AT 41HG167 \\
\hline $\begin{array}{l}\text { Material } \\
\text { Class }\end{array}$ & Number and Type of Artifact \\
\hline Ceramic & $\begin{array}{l}27 \text { undecorated whiteware sherds } \\
1 \text { undecorated semivitreous sherd } \\
1 \text { stoneware sherd, cream glaze } \\
1 \text { small earthenware sherd (Mexican- } \\
\text { made?) }\end{array}$ \\
\hline Glass & $\begin{array}{l}14 \text { colorless container fragments } \\
3 \text { white container fragments } \\
1 \text { aqua container fragment }\end{array}$ \\
\hline Brick & $\begin{array}{l}3 \text { yellow fragments (1 with concrete } \\
\text { mortar) }\end{array}$ \\
\hline Stone & 1 white marble fragment \\
\hline Concrete & 2 unidentified fragments \\
\hline Plastic & 1 unidentified red fragment \\
\hline Bone & \begin{tabular}{l}
1 sawed fragment, large mammal \\
\hline Total number of specimens observed = 56.
\end{tabular} \\
\hline
\end{tabular}

\section{CERAMICS}

Seven ceramic sherds representing six vessels were collected from the general surface of this site. One additional undecorated semivitreous whiteware vessel sherd was present but not collected. Wares consist of two coarse-paste earthenware, three white earthenware, one semivitreous whiteware, and one stoneware sherds.

The orange earthenware has an interior and exterior colorless lead glaze. The buff earthenware has a brown lead glaze interior and a colorless lead exterior. The buff stoneware is a churn rim fragment with Bristol glaze interior and exterior. Lebo (1991:161) dates vessels with Bristol glaze interiors and exteriors to the twentieth century.

The only whiteware decoration type is transfer printing. A blue saucer (?) has an unidentifiable but heavily stippled pattern consisting of a thin stripe above a linear ground. A black cup has a possibly identifiable pattern consisting of, on the exterior, an acorn and vine adjacent to a heavily stippled ground (Figure 18a), and, on the interior, a cluster of three acorns. This pattern resembles that on a purple cup from the 1846-1867 American 


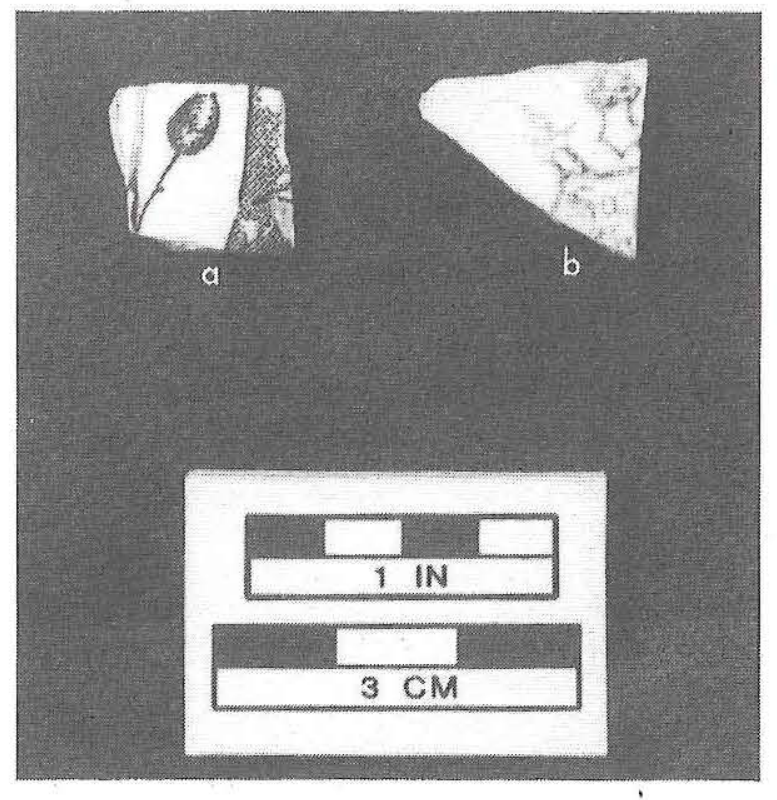

Figure 18. Decorated and marked whitewares, 41HG167. (a) Black transfer-printed vessel; (b) undecorated plate base with green transfer-printed Saxon China Co. mark.

occupation of Brazos Santiago at the mouth of the Rio Grande (Banks 1983:Figure 17H). The heavy stippling and closed or filled-in design of these sherds indicate they probably date to the first half of the nineteenth century.

Marked sherds indicate the presence of at least two additional undecorated whiteware vessels. A green-printed white earthenware sherd is marked "Sax . . ." over ". . . h . . ." (Figure $18 b$ ), a mark that was used on dishes by the Saxon China Co. of Sebring, Ohio, which was in business from 1911-1932 (Lehner 1988:407, no. 2). The mark features a medieval helmet above a shield with crossed pikes labeled Saxon China and was used on plain and decorated semivitreous dinnerware ca. 1925; Gates and Ormerod (1982:229) give the company's dates of operations as 19111929/1931. DeBolt (1988:64) dates the company's operations to ca. 1900-1929 and the helmet mark to the 1920 s.

The other plate or saucer has a black-printed curved ". . . NA" over what is probably a unicorn's mane. This mark represents the upper right portion of a British Royal Arms mark probably marked "IRONSTONE CHINA." No portions of the mark identifiable to company are present, and the mark was used widely by both British and American potters during the nineteenth and twentieth centuries (DeBolt 1988:99; Godden 1964:552).

The ceramic assemblage reflects at least two occupations, one in the first half of the nineteenth century and another in the twentieth century, probably during the 1920 s.

\section{GLASS}

No glass was collected from this site. Based on fragments recorded in the field, at least four containers are represented, one each aqua, colorless, brown, and white.

\section{OTHER MATERIALS}

A lavender plastic bowl rim sherd was collected. This artifact indicates post-World War I twentieth-century use of the site.

\section{SUMMARY}

The ceramic assemblage indicates nineteenthand twentieth-century occupations. The recorded glass colors are consistent with this range. The plastic fragment supports twentieth-century use of the site.

\section{Assessment}

It is recommended that site $41 \mathrm{HG} 167$ be considered ineligible for listing on the National Register of Historic Places and for designation as a State Archeological Landmark. It was occupied mainly during the first half of the twentieth century, but the artifacts suggest that the site also may have been occupied during the first half of the nineteenth century. However, no structures or features are present, and it is unlikely that any buried features or cultural deposits remain intact. The site consists solely of a surficial artifact scatter that has been severely disturbed by agricultural activities. Due to its lack of archeological integrity, the site does not appear to have the potential to address important research questions.

\section{Site 41HG168 (Anaqual Ranch)}

\section{Description}

Site 41HG168, an historic housesite in the flat, 
featureless alluvial plain, is located in a recently planted agricultural field (see Figure 13). It is $2.6 \mathrm{~km}$ south of the irrigation canal (Lateral A) and $150 \mathrm{~m}$ east of the centerline of the PharrReynosa International Bridge. An east-west unimproved farm road along the south edge of the site follows the edge of the alluvial terrace that rises less than $1 \mathrm{~m}$ above the floodplain of the Rio Grande, but there has been extensive land leveling in this area. The site is at an elevation of $95-99 \mathrm{ft}$ above mean sea level.

The site covers an area $30 \mathrm{~m}$ north-south by $190 \mathrm{~m}$ east-west and consists of a surface scatter of historic artifacts and modern debris. Although ground visibility in the field of small pepper plants was quite good when the site was recorded, artifact density is very low. Artifact density is much higher, however, along the terrace-edge roadway, but a considerable amount of recent debris (e.g., plastic soft drink containers, modern beer bottles, machine parts, rubber fragments, and plastic shotgun cartridge cases) is mixed in with the historic artifacts. No evidence of structures or features was encountered, and the site is extensively disturbed by agricultural activities. The linear distribution of surface artifacts along the terrace edge does not appear to be a meaningful pattern associated with the original location of the house, which was well into the field north of the road. Rather, this linear distribution is probably the result of relocation of artifacts by the modern agricultural practice of land leveling and intentional raising of the terrace-edge roadbed. This same pattern of surface artifact distribution also was observed at $41 \mathrm{HG} 153$ and $41 \mathrm{HG} 158$ (see Chapter 6).

The approximate site location of $41 \mathrm{HG} 168$ was identified as the Anaqual Ranch by an informant during the Phase I investigations (Kibler and Freeman 1993:65), and it was inspected and recorded during the current project. Nothing is shown at this location on either the 1898 or 1911 International Boundary Commission maps (see Figures 8 and 11). Later maps indicate that structures were built at the site between 1911 and 1939, and at least one structure is present on a 1939 aerial photograph (see Figure 4). Two structures (one dwelling and an outbuilding) are shown at this location on the 1962 USGS 7.5' Las Milpas quadrangle, but they are no longer shown on the 1983 photorevised version.

\section{Site History}

Site $41 \mathrm{HG} 168$ is located near the eastern edge of the Juan José Hinojosa Porción 69 Spanish land grant, which was occupied by members of the Anaya and Garza families when it was confirmed in February of 1852 (Deed Record C:586-587). No site-specific archival information was found, however, and the site's history remains poorly documented. Similarly, most El Capote informants knew nothing of the site. It is not surprising that they did not know much about the site's early history (i.e., pre-1900), but it is intriguing that most of them were unaware of the site's recent history and did not recognize its name. Anaqual may be a variation of Anacual, a Spanish word referring to a grove of anaqua (Ehretia anacua) trees.

\section{Artifacts Observed and Collected}

Surface artifacts observed at 41HG168 include a wide variety of materials, some of which are obviously of modern origin while others are obviously associated with the historic occupation (Table 14). In many cases, however, it is impossible to differentiate the old from the new, and because of this mixing, there will always be a certain amount of ambiguity regarding the historic assemblage. Artifact density was greater at this site than at any of the others in the project area, and since these materials are so abundant and obviously mixed, no attempt to quantify the surface materials was made. However, ceramic, glass, brick, shell, and plastic artifacts that clearly are associated with the site occupation were collected and are described below.

\section{CERAMICS}

Sixty-nine sherds representing 37 vessels were collected from the general surface of this site. Noncollected sherds include undecorated whitewares and stonewares, the latter with Bristol glaze probably dating to the twentieth century (Lebo 1991:161). The collected wares consist of 25 coarse-paste earthenware, 1 refined-paste earthenware, 24 white earthenware, 11 semivitreous whiteware, 4 vitreous whiteware, and 4 stoneware sherds.

The coarse-paste earthenwares represent nine 
TABLE 14

SURFACE ARTIFACTS OBSERVED AT 41HG168*

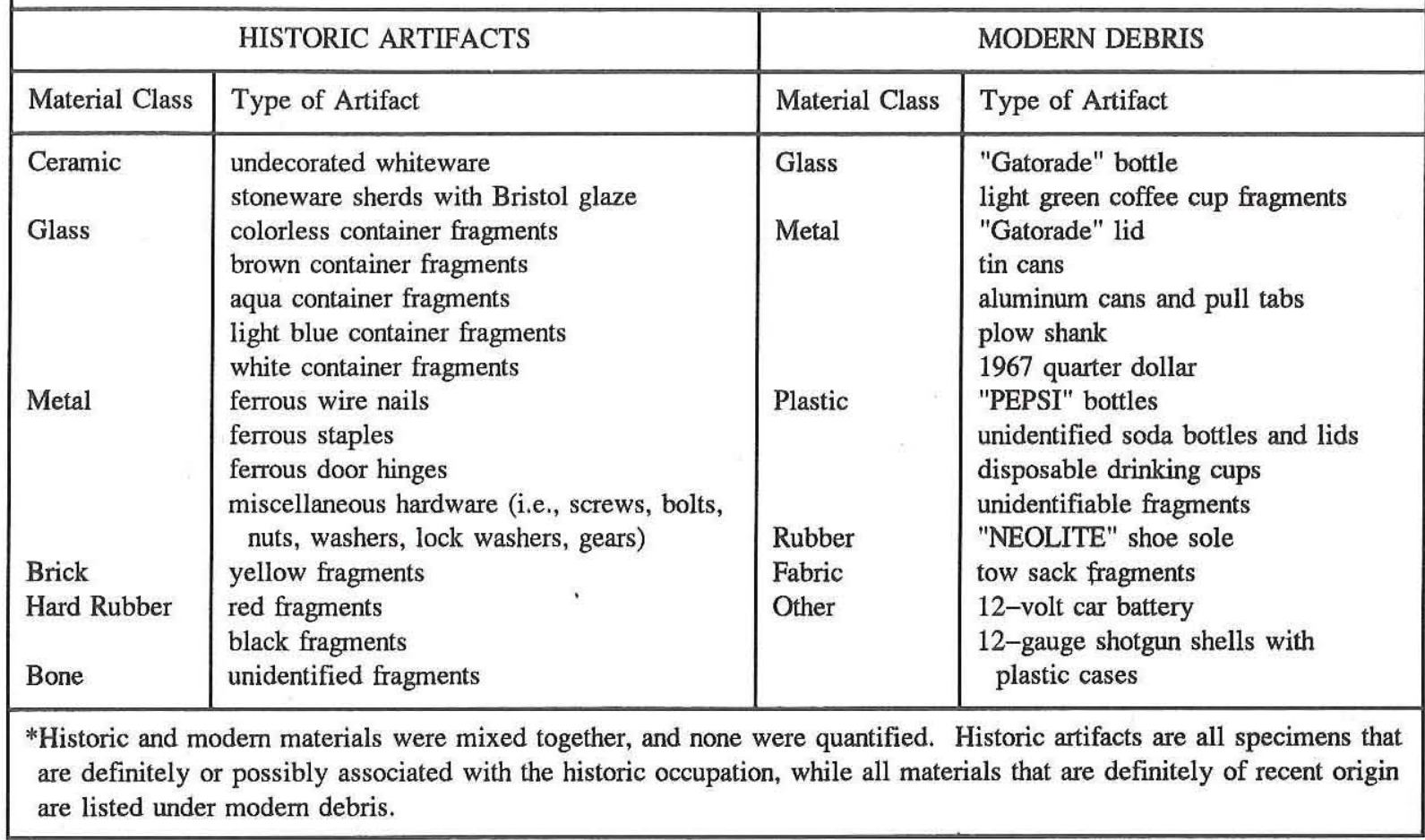

vessels, including seven orangewares. One orange to gray vessel has an exterior green lead glaze and an interior colorless lead glaze. A second orange vessel has an interior and exterior colorless lead glaze. A third vessel has an orange paste with a brown core and a colorless lead-glazed interior. A fourth orange vessel is thin and unglazed. A fifth orange vessel has interior and exterior colorless lead glaze; a white line occurs on the exterior. The sixth orange vessel has interior and exterior colorless lead glaze. The seventh orange vessel has no glaze. The thin-walled lead-glazed orange vessels may represent undecorated portions of Galera ware, which dates from 1750 until the early 1800 s or later in Texas (Dial 1992:34; Fox 1986:111). Thick-walled vessels may be undecorated portions of Red Brown Ware (Dial 1992:34). The grayware vessel has a dry interior and colorless lead-glazed exterior. Another vessel has a buff paste with gray core and is unglazed.

The refined buff earthenware has a yellowwarelike decoration consisting of yellow and brown bands on the exterior; the interior is unglazed. The stonewares are two unglazed wheel-thrown buff vessels and a molded-base buff flowerpot (?) with an interior flesh-colored clay glaze with black speckles and an exterior clay glaze with fleshcolored overglaze drips.

Whiteware decoration types are annular, underglaze hand painted, overglaze hand painted, possible sponge stamped, transfer printed, decal, and unknown (Table 15). In addition, one undecorated very thick semivitreous whiteware bowl is present.

Four vessels with banded annular decoration are represented: Three have the muted earth tones of dark brown bands and gray-blue ground (Figure 19a) characteristic of dipped vessels dating to the first half of the nineteenth century (Majewski and O'Brien 1987:163; Miller 1991:7). The fourth has olive bands and a light blue ground (Figure 19b) and may date to the second half of the nineteenth century.

Thickline and fineline floral patterns occur on sherds with underglaze hand-painted decoration. The examples of thickline decoration represent one vessel each of monochrome blue and monochrome red (Figure 19c), while the examples of fineline 


\begin{tabular}{|l|l|l|l|}
\hline \multicolumn{5}{|c|}{ THITEWARE CERAMIC DECORATION TYPES, 41HG168 } \\
\hline Decoration Type & Pattern & Color & Vessel Form \\
\hline Annular & banded & $\begin{array}{l}\text { brown } \\
\text { olive and blue } \\
\text { brown and blue ( } \mathrm{n}=2)\end{array}$ & $\begin{array}{l}- \\
-\end{array}$ \\
\hline Underglaze hand painted & thickline floral & $\begin{array}{l}\text { blue } \\
\text { red } \\
\text { red and black } \\
\text { bright blue, green, and black }\end{array}$ & $\begin{array}{l}\text { cup? } \\
-\end{array}$ \\
\hline Overglaze hand painted & fineline floral & $\begin{array}{l}\text { silver } \\
\text { silver }\end{array}$ & $\begin{array}{l}\text { saucer } \\
\text { candlestick holder? }\end{array}$ \\
\hline Sponge stamped? & floster band & red and blue & - \\
\hline Transfer printed & $\begin{array}{l}\text { unidentified } \\
\text { floral } \\
\text { floral? } \\
\text { geometric? }\end{array}$ & $\begin{array}{l}\text { blue } \\
\text { blue } \\
\text { teal green } \\
\text { brown }\end{array}$ & $\begin{array}{l}\text { saucer } \\
\text { cup? }\end{array}$ \\
\hline floral & blue & - \\
\hline Flow & floral & gold, pink, green, blue & hollowware? \\
\hline Decal with hand painting & floral? & pink & \begin{tabular}{l} 
saucer? \\
\hline Decal
\end{tabular} \\
\hline Unknown & - & $\begin{array}{l}\text { mauve and green } \\
\text { blue and pink } \\
\text { blue } \\
\text { blue }\end{array}$ & saucer \\
\hline
\end{tabular}

decoration are fragments of black stems and polychrome flowers representing two vessels. Both patterns occur primarily on teawares.

Pre-1840 thickline colors included monochrome cobalt blue and polychrome earthen colors, and additional polychrome colors including red were used on earthenwares from 1840 to 1860 (Majewski and O'Brien 1987:157). The blue vessel probably predates the Civil War, and the red (polychrome?) vessel dates to midcentury.

The fineline floral patterns occur on such small sherds that identification of specific patterns is impossible. The largest fragment has red flower buds with a black stem. All four sherds have fragments of black stems. Fineline floral patterns (Majewski and O'Brien [1987:157] use the term sprig pattern) were popular from 1840-1860 (Majewski and O'Brien 1987:159).
Overglaze hand-painted decoration in the form of a thin band of luster paint occurs on a sherd of a vitreous saucer and a possible candlestick holder. The remainder of the decoration, if any, is unknown.

One possible sponge-stamped or cut-sponge vessel is represented. The smeared edge of the red possible floral motif fragment resembles spongestamped decoration. A light blue line occurs above the red motif. Sponge stamping was common between the late 1840s and the 1870s (Miller 1991:6). The cut-sponge process was developed in 1845 , and the Portneuf pattern was exported to Canada from the 1840s to 1920 (Majewski and O'Brien 1987:161-162).

Four vessels are represented by sherds with transfer printing. Three sherds have unidentified closed patterns probably dating to the first half of 


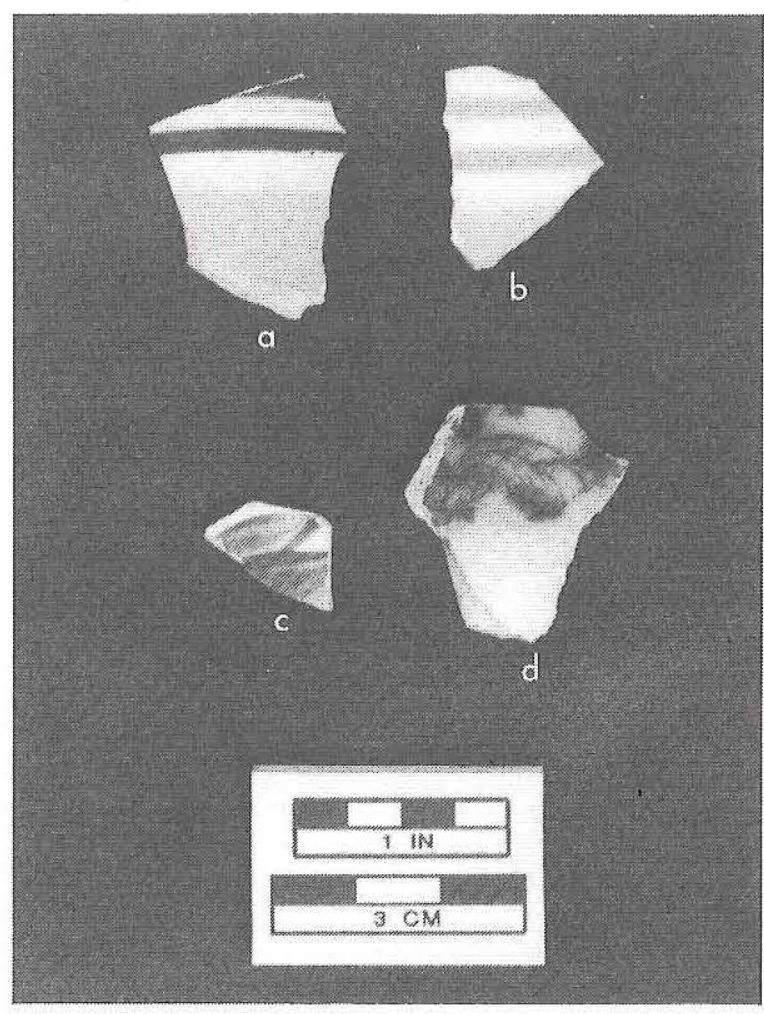

Figure 19. Decorated whitewares, 41HG168. (a) Banded vessel, dark brown bands and gray-blue ground; (b) banded vessel, olive green bands and light blue ground; $(c)$ red thickline floral vessel; $(d)$ flow blue transfer-printed semivitreous hollowware(?).

the nineteenth century and may be from a single saucer, although one is semivitreous and two are white earthenware. Three transfer-printed vessels (one each in cobalt blue, teal green, and brown) have open, boldline patterns probably dating to the twentieth century. A semivitreous paneled hollowware (?) vessel (Figure 19d) with flow blue decoration probably dates to the $1835 / 1840-1910$ period (Williams 1981:ii).

Sherds with floral decals represent two vessels. A semivitreous to vitreous whiteware saucer (?) has a gold rim band, pink and green decal, and hand-painted blue band over the decal. A vitreous whiteware saucer has a pink decal with a probable floral pattern.

Sherds representing six additional vessels have underglaze color of unknown decoration type. One of these vessels has earthen blue colors and may represent annular decoration.

Ceramic decoration types dating to the first half of the nineteenth century are banded and transfer printed. Midcentury (late 1840s-1860s) types are fineline floral, flow blue, and sponge stamped. Early twentieth-century types are floral decals, and patterns dating to the second quarter of the twentieth century are open-design transfers.

\section{GLASS}

Two fragments of glass were collected (Table 16). Neither is fluorescent under shortwave ultraviolet light, indicating lack of lead content. A white plate and a colorless votive candleholder base are represented. Additional fragments observed but not collected represent aqua, brown, and light blue containers. Also observed were a recent Gatorade bottle and a milky green coffee cup. The candleholder base is embossed with a keystone containing a $7, ; \mathrm{T}$, or geometric symbol; this mark is not listed in Toulouse (1971:293-294, 371) with other keystone marks (K, U, P, S). A valve mark indicating a 1930s-1950s date (Miller and Sullivan 1989:109) is present, however.

\begin{tabular}{|l|l|}
\hline \multicolumn{2}{|c|}{ TABLE 16 } \\
COLLECTED GLASS, 41HG168 \\
\hline Color and Type & No. and Description \\
\hline $\begin{array}{l}\text { colorless } \\
\text { votive } \\
\text { candleholder }\end{array}$ & $\begin{array}{l}\text { 1 base with cup base seam and } \\
\text { valve mark; marked with } \\
\text { "REED CANDLE CO" over } \\
\text { "SAN ANTONIO, TEX" over } \\
\text { "[keystone with 7 or T] 11" }\end{array}$ \\
\hline white plate & $\begin{array}{l}\text { 1 rim sherd with overall medium } \\
\text { green enamel paint on interior }\end{array}$ \\
\hline
\end{tabular}

\section{BRICK}

A single brick fragment (approximately onehalf) is $107+\mathrm{mm}$ long, $93 \mathrm{~mm}$ wide, and $59 \mathrm{~mm}$ thick and exhibits some recent plow damage. It has an irregular struck face that is almost completely covered with a thin layer of mud or concrete mortar, and sparse remnants are present on the molded face. Mortar remnants also are present on the sides and the ends and are as much as $17 \mathrm{~mm}$ thick. The surfaces have a sandy texture, as does the brick's very porous matrix which grades in color from buff to salmon. No obvious inclusions were noted, but the matrix is 
very soft (i.e., hardness 3-4). This specimen is a hand-molded, sand-struck, soft-mud brick. It is very similar to handmade bricks collected from the brick factory (i.e., Types 2, 6, and 7 from 41HG156, see Chapter 6 and Appendix B) and from other El Capote housesites (e.g., 41HG158 and 41HG164).

\section{OTHER ARTIFACTS}

Four other artifacts were collected. An opaque cobalt blue and white machinemade glass marble is not perfectly round and measures 0.45 inch in diameter. This type dates from the earliest machine manufacture ca. 1911 to the present, with greatest popularity in the 1930s (Randall n.d.:6).

Two pearl buttons are present. One has a flat top and a self shank with a layer of white plastic glued to the bottom of the attachment and measures 0.6 inch in diameter. The other is a dish-type two-hole button with flat rim, concave center, and sloping back and measures 0.4 inch in diameter. Shell buttons surpassed pearl buttons in popularity in the United States after the 1890s, and these buttons were replaced by less-expensive plastic after World War I (Pool 1991:n.p.). The component pearl and plastic materials and shapes indicate a twentieth-century, probably 1920 s-1930s, date for these buttons.

Also present is a plastic dice fragment. The exterior has been colored yellowish brown (the interior is brown) to resemble ivory. This piece postdates World War I based on the material.

\section{SUMMARY}

The ceramics indicate occupation in the early to mid nineteenth century and first and second quarter of the twentieth century. The valve mark on the candleholder base is consistent with a second quarter of the twentieth century date. The marble probably dates to the first quarter of the twentieth century, as do the pearl buttons and the plastic dice.

\section{Assessment}

It is recommended that site $41 \mathrm{HG} 168$ be considered ineligible for listing on the National Register of Historic Places and for designation as a State Archeological Landmark. This site appears to have been occupied during the mid to late nineteenth century until the mid twentieth century, but it is not known if the occupation was continuous or intermittent. No structures or features are present, however, and it is unlikely that any buried features or cultural deposits remain intact. The site consists solely of a surficial artifact scatter that has been severely disturbed by agricultural activities and dumping of modern debris. The distribution of artifacts, concentrated in a linear pattern along the edge of the terrace, suggests that these materials were bladed to the edge of terrace. The interpretability of the historic artifact assemblage is limited further by mixing with a considerable amount of recent debris. In some cases, historic artifacts cannot be distinguished from modern debris. Due to its lack of archeological integrity, the site does not appear to have the potential to address important research questions.

\section{HISTORIC SITES ADJACENT TO THE AREA OF POTENTIAL EFFECTS}

During the course of the historic archival and informant investigations, it became apparent that several historic sites associated with the former community of El Capote existed or probably existed adjacent to the area of potential effects. Four locations were identified, but only one was field checked and recorded, while the other three probable site locations remain unconfirmed (see Figure 14). Since the Cantu Housesite, 41HG169, lies mostly on private land, permission to document the location was obtained from Prudencio Cantu. The three other locations - a segment of the Old Military Road with possible nearby structures, the second location of the Garza Ranch, and the de la Viña Ranch - are located on Fish and Wildlife Service lands and were not investigated.

\section{Site 41HG169 (Cantu Housesite)}

\section{Description}

Site 41 HG169 is an historic housesite located ca. $120 \mathrm{~m}$ south of the irrigation canal (Lateral A) and $1.5 \mathrm{~km}$ west of the centerline of the PharrReynosa International Bridge. It is situated on the flat alluvial terrace approximately $50 \mathrm{~m}$ north of an unnamed resaca (see Figure 14). The southern edge of the terrace is $1-2 \mathrm{~m}$ higher than and forms 
the northwestern edge of the resaca. The western two-thirds of the site is on privately owned land, and several modern houses at the north end of the site are occupied by members of the Cantu family. The eastern one-third of the site is on land owned by the Fish and Wildlife Service, and a north-south fenceline forms the boundary between the two tracts. The site is at an elevation of $101 \mathrm{ft}$ above mean sea level, and an International Boundary Commission datum (a square concrete block stamped "RP 22" with an iron plate marked
"IBC \& C de L") is located in the central portion of the site.

The site covers an area $125 \mathrm{~m}$ north-south by $135 \mathrm{~m}$ east-west. According to informant Prudencio Cantu (1993), the site once contained two brick houses, three jacales de leña (mesquite jacales), and three board-and-batten houses (Figure 20). The two brick houses were built in the $1880 \mathrm{~s}$, and one is still standing (hereafter called the Cantu house), while the location of the other is now marked only by a scatter of bricks.

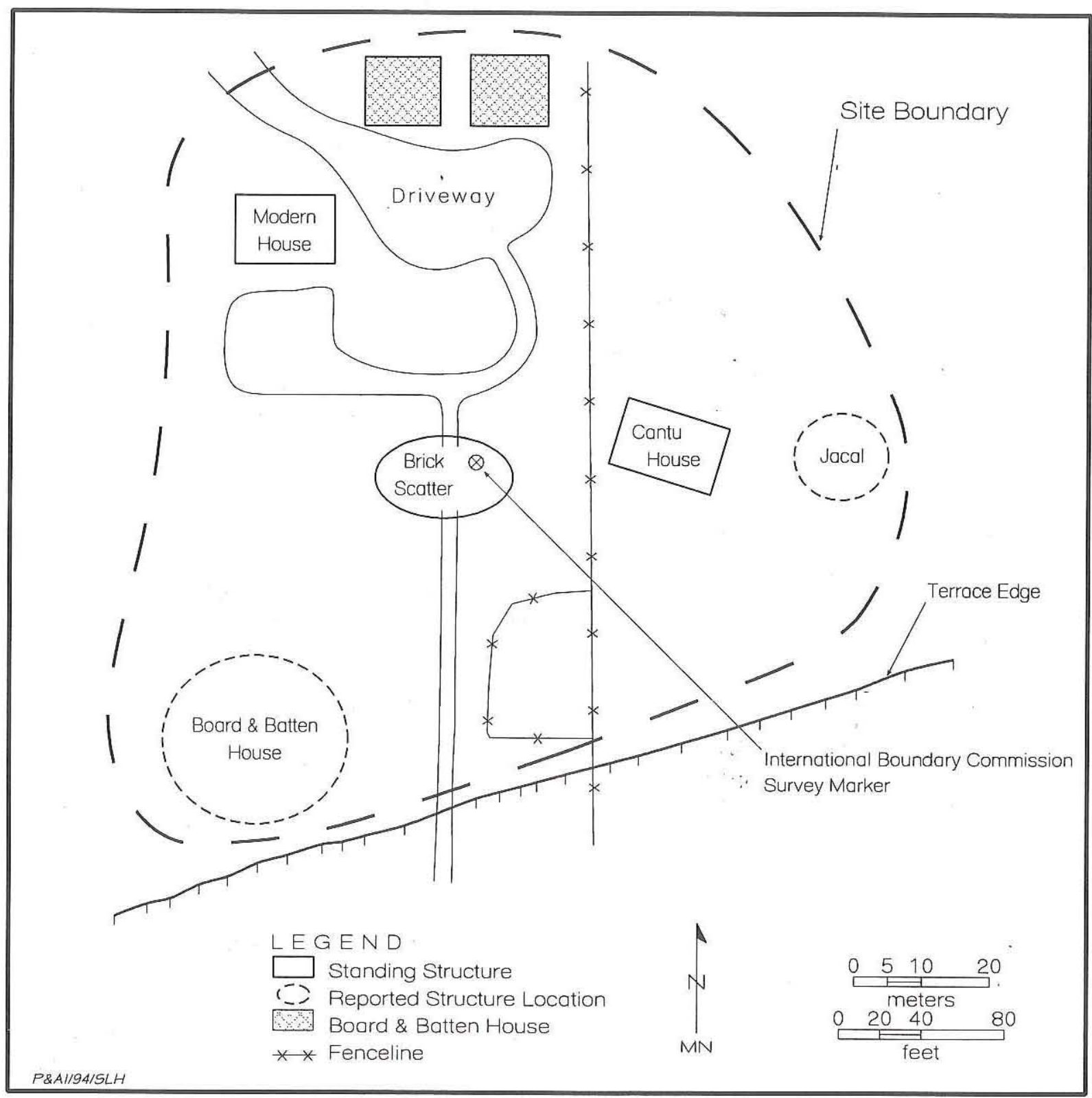

Figure 20. Paced sketch map of the Cantu Housesite, 41HG169. 
None of the jacales are present now. One was located just east of the Cantu house and served as its kitchen. The other two were torn down and replaced in the 1930 s or 1940 s with the two standing board-and-batten houses at the north end of the site. A third board-and-batten house at the southern end of the site was built in the 1930s but was removed from the site in the 1960s.

The Cantu house is a rectangular, single-room structure with brick walls two courses wide with mud mortar in between and evidence of several layers of white lime plaster. The brick walls are all standing except for a collapsed section along the south wall. The structure has a simple hipped wooden roof constructed of $2-x-4-i n c h$ milled lumber and wooden shingles. The roof is already in an advanced state of decay with several large sections collapsed. It is unclear whether this is the original roof or a later improvement. Other modifications to the original structure are clearly evident and include doorways that have been bricked in and a thick outer layer of concrete plaster, remnants of which are seen in the interior and exterior (Figure 21a).

The Cantu house appears to represent an unusual type of brick architecture in the Rio Grande Valley (Joe S. Graham, personal communication 1993). One particularly interesting construction technique is revealed in the partially collapsed northeast corner (Figure 21b). The corner consists of a square column of bricks around a vertical wooden post that is reminiscent of jacal corner posts (horcones). This appears to represent a marriage of traditional Hispanic vernacular and brick architecture, but the distribution and significance of this type of construction are not fully understood.

The former location of the second brick house is indicated by a $15-x-20-m$ diffuse scatter of bricks and other debris that appears to have been dumped there. There is no surface evidence of a foundation, and the limited number of bricks in the area suggests that most of them were removed from the site, probably salvaged for use elsewhere. The jacal area, located ca. $15 \mathrm{~m}$ west of the standing Cantu house on Fish and Wildlife Service land, was not investigated, and the location of the former wood-frame house could not be investigated because it was grown over in dense vegetation.

Although 41HG169 is located outside the area of potential effects and will not be subject to any impacts due to construction of the Pharr-Reynosa International Bridge, this site contains the only documented standing residential structure that is associated with the former community of El Capote
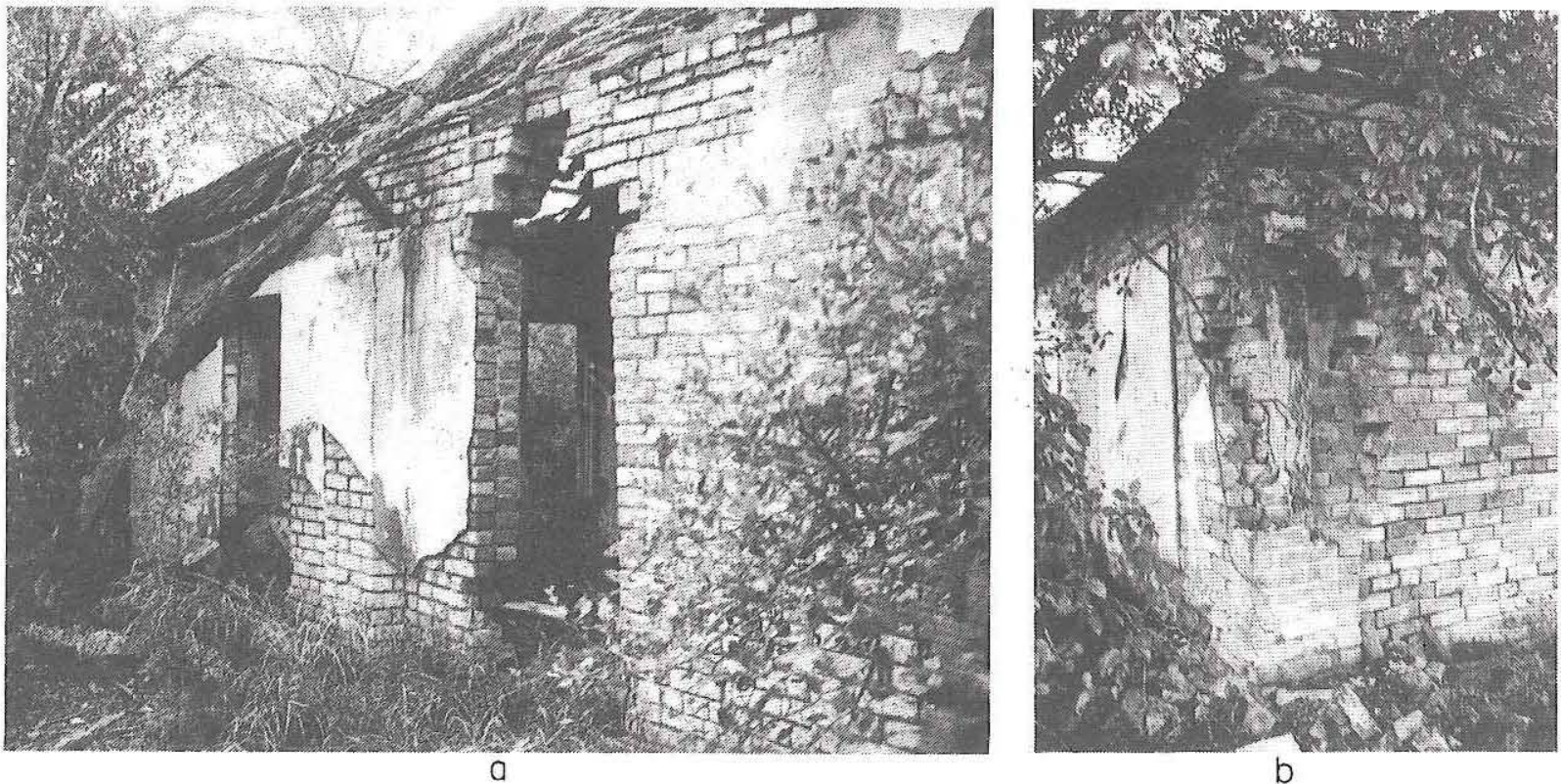

Figure 21. The Cantu house, 41HG169. (a) Southeast view of the north wall; note the remnants of multiple layers of plaster and the two-course-wide brick wall visible in the doorway; $(b)$ east view of the partially collapsed northwest corner; note the two-course-wide brick walls and the vertical wooden post inside the square column of bricks. 
(although locations of other possible El Capote structures east of 41 HG169 have not been investigated; see Old Military Road below). As such, the site is of considerable importance in relation to the other El Capote historic sites documented within the project area. The site appears to have good archeological integrity, and the standing Cantu house is especially important, not only because it is the only extant structure associated with the former El Capote community but also because it is likely to be one of the few surviving examples of an unusual style of late nineteenth-century South Texas architecture. While it will not be impacted by the Pharr-Reynosa International Bridge and no official assessment and recommendations are made, the Cantu Housesite clearly has a great deal of archeological and architectural integrity and may be eligible for listing on the National Register of Historic Places. Minimally, the Cantu house warrants detailed documentation (e.g., according to Historic American Building Survey standards), and the feasibility of stabilization and preservation should be considered.

\section{Site History}

While no attempt was made to trace the chain of title for this property, site 41 HG169 is located near the southwestern edge of the Juan José Hinojosa Porción 69. One of the current residents, 69-year-old Prudencio Cantu (1993), was able to provide a great deal of information regarding the site. The Cantu family currently owns 49 acres of the original El Capote Ranch (which includes most of 41HG169), and at least four generations of Cantus have lived there since the late nineteenth century. Prudencio's great grandfather, Juan Nepomuceno Cantu, had two sons, Juan Manuel and Prudencio (the informant's grandfather), who figure prominently in the history of El Capote (Figure 22). Juan Manuel Cantu and his wife María Espinosa Cantu settled at El Capote and had five children while living there. Juan's brother Prudencio was murdered in 1904, and Prudencio's 4-year-old son, José E. Cantu, grew up at El Capote. José married Leonor Castillo, and they had five children, all of whom were born at El Capote between 1924 and 1932. Prudencio (the informant), who is the eldest of the five children, and his brother Erasmo still live at 41HG169.

Prudencio Cantu (1993) said that the standing brick house was built in the 1880 s by his grandfather's brother, Juan Manuel Cantu, and was occupied continuously by members of the Cantu family until ca. 1935-1936. It subsequently was used by families from Mexico until its final abandonment in the 1950s; in 1993 it was located on a bird sanctuary owned by the U.S. Fish and Wildlife Service. The second brick house at 41HG169 belonged to Prudencio Cantu's aunt,

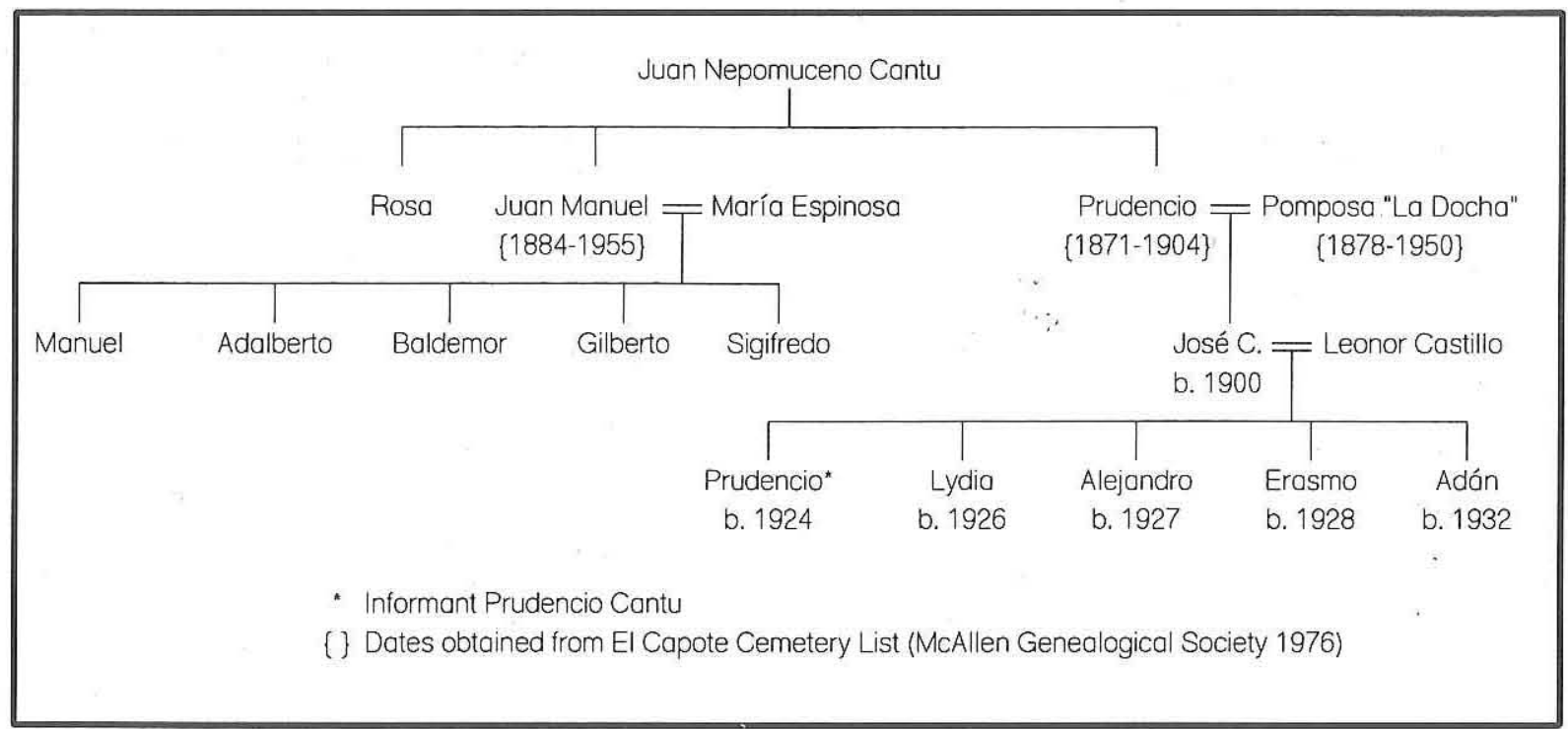

Figure 22. Genealogy of El Capote Cantu family. All data are from informant interview (Cantu 1993) unless otherwise stated. 
Isabel Muñoz Cantu, and may have been built at about the same time as the Cantu house.

Informant data are substantiated by historic maps that indicate that site $41 \mathrm{HG} 169$ has existed continuously since before the turn of the century. While the site area is not clearly shown on an 1898 map (see Figure 8), the 1911 International Boundary Commission map (see Figure 11) definitely depicts two structures in close proximity to the RP 22 survey marker. Structures are shown in the site area on a 1939 aerial photograph (see Figure 4). Several structures also are shown at this location on the 1962 USGS 7.5' Las Milpas quadrangle and on the 1983 photorevised version of that map.

\section{Artifacts Observed and Collected}

Bricks are the main type of artifact.observed at $41 \mathrm{HG} 169$, but only two specimens were collected. No collections were made from the standing Cantu house, and both of the collected bricks were recovered from the second brick house (i.e., the brick scatter at the RP 22 survey marker). The collected specimens, as well as all of the observed bricks, are hand-molded, sand-struck, soft-mud bricks, and these particular specimens were selected because they have raised markings on their molded faces.

One complete brick with only minor damage along one edge is $210-211 \mathrm{~mm}$ long, 104-105 mm wide, and $64-65 \mathrm{~mm}$ thick and weighs $2,245 \mathrm{~g}$. Its weight may be somewhat high, however, since it includes some substantial remnants (up to $14 \mathrm{~mm}$ thick) or mud or concrete mortar on its struck face. Except for the mortar remnants, the struck face has a very irregular rough texture, while the molded face is rather smooth and has a raised mark centered vertically in the face (Figure 23a). This mark could be a cattle brand, but it has not been identified. The molded face, sides, and ends all have a sandy texture, and one side is mostly covered by a thin (i.e., less than $0.5 \mathrm{~mm}$ thick) layer of white lime plaster. The salmon-colored, fine sandy matrix is rather soft (i.e., hardness 3-4) and slightly porous. All of the edges are rounded.

One brick fragment (approximately one-half) is $142+\mathrm{mm}$ long, 101-102 $\mathrm{mm}$ wide, and 65$66 \mathrm{~mm}$ thick. Its struck face is mostly covered with a 4-6-mm-thick layer of mud mortar, while the other surfaces have only minor remnants of

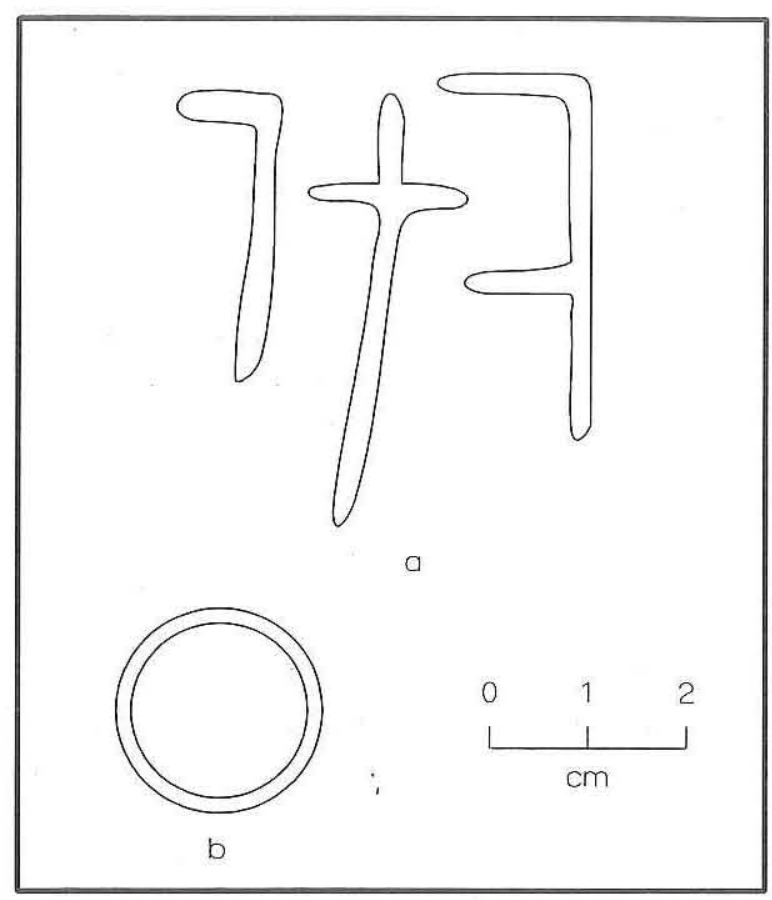

Figure 23. Raised markings on the bricks collected from 41HG169. (a) Mark on complete brick; (b) mark on brick fragment.

mortar, except for one side which has remnant of white lime plaster. The molded face has a raised 21-mm-diameter circle (Figure 23b) in its center. The faint mark is somewhat eroded and is less than $1 \mathrm{~mm}$ high. Since this marking has not been identified, it is not known whether it is a cattle brand or some other type of identifying mark. This same mark, however, also was observed on bricks in the standing Cantu house (described below) and on a brick that may have been associated with the Ramirez house at $41 \mathrm{HG} 158$. The salmon-colored, fine sandy matrix is fairly soft (i.e., hardness 4) and very porous. No obvious inclusions were noted, and the brick's edges are fairly sharp.

None of the other bricks observed in the brick scatter area have any markings. The plain bricks vary somewhat in size, but most specimens that were examined are either ca. $220 \mathrm{~mm}$ long, $103 \mathrm{~mm}$ wide, and $65 \mathrm{~mm}$ thick, or they are slightly smaller at ca. $195 \mathrm{~mm}$ long, $95 \mathrm{~mm}$ wide, and $55 \mathrm{~mm}$ thick. This variability may indicate that two different sets of bricks, perhaps representing bricks fired at different times, were used in the construction of the former house. The smaller bricks are consistent in size with the Type 2 bricks that may have been made at the nearby brick 
factory, site 41HG156 (see Chapter 6).

Most of the bricks observed in and around the Cantu house also are plain bricks. They vary somewhat in size but are generally from $215-220 \mathrm{~mm}$ in length, $98-100 \mathrm{~mm}$ in width, and $52-60 \mathrm{~mm}$ in thickness, with thickness being the most variable. A few of the bricks observed at the Cantu house have markings, but only three different marks were noted. A few specimens have small circular raised marks (1-2 mm high) located in the center of their molded faces, but two different sizes were observed. One circular mark is $20-21 \mathrm{~mm}$ in diameter, while the other is slightly smaller with a diameter of $15-16 \mathrm{~mm}$. The third mark was noted on only one brick. It is a large script letter " $Y$ " that was incised 1-2 mm deep into the molded face of the brick while the clay was still wet. Since this mark was not made during the molding process, it probably was not intended to identify the location or name of the manufacturer. It may have been a mark made by an individual brickyard worker to identify a particular group of bricks as having been made by a specific brickmaker and/or handled by a specific crew. Such marks often were made to keep track of who made what because brickyard workers often were paid according to the number of bricks that they produced (Anonymous 1914). Alternatively, the mark may be nothing more than a worker's idle doodle in a wet brick.

\section{Old Military Road}

\section{Description}

The "Old Military Road" (also called the Military Highway, Camino Militar, and Brownsville Road) once transversed the project area from east to west (see Figure 14), but no evidence of it was encountered in the area of potential effects. Throughout the the area of potential effects, the former road is located in plowed agricultural fields, and there is no potential for any segments to remain intact. Immediately north of 41HG156 is a short east-west segment of an unimproved farm road that appears to be in the same general location as the Old Military Road. Unfortunately, even this segment has been altered by modern land leveling and farming activities.

Immediately west of the area of potential effects, however, remnants of the Old Military
Road may be preserved on Fish and Wildlife lands. Historic maps (see Figures 8 and 11) clearly show that the Old Military Road extended eastward from the north edge of $41 \mathrm{HG} 169$ and passed along the north edges of $41 \mathrm{HG} 156$ and 41HG157 (the latter two sites being located in the area of potential effects). Since the area immediately east of the Cantu Housesite is an undisturbed tract of Fish and Wildlife Service land, it is possible that some remnants of the old road are preserved there. A 1911 International Boundary Commission map (see Figure 11) shows at least five "Capote Ranch" structures east of the Cantu Housesite and between the resaca and the irrigation canal (Lateral A). Informants indicated that El Capote schoolhouse was in this same general area, and a black-andwhite photograph in the possession of Olivia Ramirez (Ramirez et al. 1993) taken in the 1940s or 1950 s indicates that it was a wood-frame structure. Since this property was not investigated, it is not known if any evidence of the Old Military Road, the schoolhouse, or any other historic structures or features still exists, but it is likely that the area is relatively undisturbed (see El Capote complex on Figure 14 map).

\section{Site History}

The Old Military Road (El Camino Militar) was a major landmark that traversed El Capote from east to west, south of the present-day Lateral A irrigation canal and 0.7 mile south of U.S. Highway 281 (see Figure 14). It is depicted as the "Road to Brownsville" on an 1878 map (see Figure 7) and as the "Brownsville Road" on maps from 1898 (see Figurre 8) and 1911 (see Figure 11). The original location of the old road is south of Lateral A as shown on a 1926-1927 map (see Kibler and Freeman 1993:Figure 5), but another "Military Road to Brownsville" is shown north of Lateral A. This road approximates the route of U.S. Highway 281 and suggests that this had become the preferred east-west route by ca. 1927 .

Laid out by the U.S. Army under General Zachary Taylor during the Mexican War in 1846, the Military Road paralleled the Rio Grande along the north bank from Laredo to Brownsville. Although established for Taylor's army logistics and maneuvers, the Military Road has been used by numerous armies and armed bands since the Mexican War. 
One of the first armed forces to utilize the Military Road at El Capote was the notorious rebel Juan Cortina. Cortina, who operated for years out of the Brownsville area after 1859, apparently used the Old Military Road and ferries in Hidalgo County in his troop movements, although there is no documentation that he visited or attacked El Capote proper. His pursuers, including Brevet Colonel Robert E. Lee, also traversed El Capote on the Old Military Road as he followed Cortina's army. On Christmas day of 1859 , U.S. Army Major S. P. Heintzelman led troops in pursuit of Cortina into Hidalgo County. Heintzelman recorded that "the next place I was told that we should certainly meet him [Cortina] was in a bend of the river a mile beyond-Edinburg [present-day Hidalgo]. We reached Edinburg on Sunday, the 25th of December." The next spring, Colonel Robert E. Lee led troops from Rio Grande City to Brownsville, stopping at Edinburg [present-day Hidalgo] to issue a proclamation. On April 9, 1860 , Lee moved to a "camp below Edinburg" where he issued another letter to the authorities of Reynosa, and then proceeded down the Military Road, which traverses El Capote, to Brownsville (U.S. 36th Congress, 1st Session 1860:8, 88).

The Military Road through El Capote also was used extensively by Confederate Colonel John S. "Rip" Ford during the Civil War. In November 1861 , for example, Ford reportedly "blocked the ferries across the Rio Grande" in order to preserve neutrality after Carvajal's army attacked Matamoros. The next spring, Carvajal and 500 troops crossed the river from Texas and attacked Reynosa as reported by the Fort Brown Flag of Brownsville (Tyler 1973:63). In these incidents, and after the Battle of Las Rucias Ranch in 1864, Ford used the Military Road for troop movements. Ford also reportedly used the ferries in the Hidalgo County area in pursuit of raiders (Pierce 1917:48).

Local twentieth-century informants indicate that the road was used by residents of El Capote for trade. Pedro Guajardo, who had a brick kiln until the 1920s on El Capote, reportedly used the Military Road (El Camino Militar) for brick sales to other ranches (Garza and Garza 1993).

\section{Garza Ranch No. 2}

\section{Description}

Garza Ranch No. 2 is an unrecorded historic site located on Fish and Wildlife Service land immediately east of the Pharr-Reynosa International Bridge area of potential effects. The locality is along the edge of a prominent unnamed resaca (see Figure 14) and is known through archival and informant data. Although this locality was not field checked, evidence of historic housesites is visible from the adjacent roadway. The flat area between the road and the resaca consists of two large rectangular fields that may have been cleared when the houses were built. These areas are now covered with a dense stand of grass and the houses themselves are gone, but related features are visible from the road. A line of abandoned wooden electrical poles ends at this spot, and the last pole has hookups that once may have held a transformer that provided electricity to one of the houses. A round concrete tank nearby also may have been associated with the housesites. Hence, although the presence of these historic El Capote housesites has not been confirmed, it seems likely that some physical evidence still exists.

\section{Site History}

No site-specific archival work was conducted relating to the Garza Ranch No. 2, but it is located in the southern part of the Juan Jose Hinojosa Porción 69. Historic maps suggest that the site was occupied continuously throughout much of the nineteenth century. Two probable structures are depicted on the 1898 International Boundary Commission map (see Figure 8), and three structures on the 1911 International Boundary Commission map (see Figure 11) are designated as "Capote Ranch." Structures appear in the site area on the 1939 aerial photograph (see Figure 4), and one structure is still shown on the 1962 USGS 7.5' Las Milpas quadrangle. No structures are depicted on the 1983 photorevised version of the Las Milpas quadrangle, indicating that the last structure disappeared between 1962 and 1983.

Most of the information relating to this site was obtained through informant interviews (Garza and Garza 1993; Ramirez et al. 1993). Garza Ranch No. 2 is associated with the descendants of Guillermo Garza, Sr., who was born ca. 18601865. He is believed to have come to El Capote from Mexico and was the first Garza to be associated with the community (Figure 24). He and his wife, Manuella Gomez Garza, lived at 41HG153 and had 7 children and 38 grandchildren, 


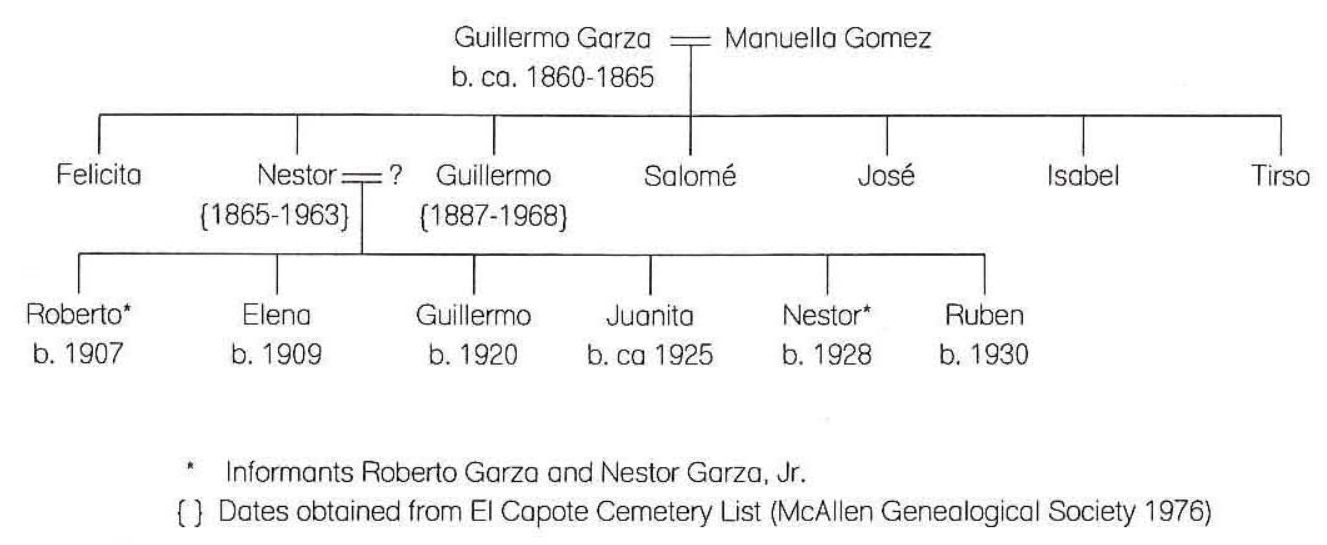

Figure 24. Genealogy of El Capote Garza family. Data from informant interview (Garza and Garza 1993) unless otherwise stated.

all of whom were born at El Capote.

While Guillermo Garza, Sr., is associated with the original Guillermo Garza Ranch, site 41HG153 (see Chapter 6), one of his children, Guillermo Garza, Jr., also is associated with a ranch of the same name. This second site, which has been informally named the Garza Ranch No. 2, was identified by informants as being several hundred meters north of $41 \mathrm{HG} 153$.

Local informant Roberto Garza was born on his uncle Guillermo Garza, Jr.'s, ranch in 1907 (Garza and Garza 1993). At that time, it was the location of a casa de reboque, which is similar to but larger than a jacal de leña. Like a traditional jacal, it had four corner posts (horcones) which supported a gabled thatch roof. The walls were made of cut mesquite (leña) and were plastered with mud and lime inside and out. While jacales generally had dirt floors, Guillermo Garza, Jr.'s casa de reboque had a brick floor and a woodburning stove (estufa de leña).

\section{de la Viña Ranch}

\section{Description}

Archival and informant evidence indicates that the de la Viña Ranch was located within a large circular resaca, presently located on Fish and Wildlife Service lands east of the Pharr-Reynosa International Bridge area of potential effects. This area, shown on the USGS 7.5' Las Milpas quadrangle maps (1962 and 1983 photorevised) as "Don Juan Cross Banco No. 155," is apparently the location of the ranch associated with Manuel de la Viña, whose family may have lived there as early as 1821 and throughout much of the nineteenth century (Ponce 1993). While this was one of the oldest settlements in the area that later became known as El Capote, historic maps and aerial photographs suggest that the site may have been destroyed by the meandering of the Rio Grande during the last 100 years (see Figures 2, 4, and 5). The exact location of the river channel during the occupation of the site is not known, but it apparently began meandering and migrating northward late in the nineteenth century. Between 1897 and 1939, a large meander bend migrated northward across the area and probably destroyed the site. The 1939 aerial photograph (see Figure 4) shows that Banco No. 155 was part of Mexico at that time. Sometime after 1939, the neck of the meander bend became so narrow that the Rio Grande broke through into its current channel, leaving the circular resaca encompassing Banco No. 155 as an isolated oxbow, once again on the north side of the river. During the late nineteenth and early twentieth centuries, the river may have made a slow, continuous migration across the banco area, thus destroying all of the de la Viña Ranch. Conversely, the river migration may have been sporadic and portions of the banco may have been preserved as the river jumped from one channel location to the next. Consequently, it is 
not known whether any physical remains of the de la Viña Ranch exist today.

\section{Site History}

The de la Viña family lived at El Capote on an oxbow island formed by a river meander (now known on surveys as Don Juan Cross Banco No. 155 ) in Porción 70, but only a small portion of the island is in the project area. The land was bought in the late 1850 s by Juan Manuel de la Viña. Juan was the son of Reynosa Chief Justice Don Manuel de la Viña, who was originally from Quijon, Spain. The family was prominent in Spain, Mexico, and Texas. Don Manuel de la Viña was on the Reynosa Ayuntamiento (City Council) in the 1840s when he and his sons, Juan and Plutarco, paid taxes there. Later, Juan and Plutarco would serve as Hidalgo County commissioners and judges and help to incorporate the city of Edinburg (Archivo Historico de Reynosa; Washington 1983:83).

Although the de la Viñas were located on the periphery of the project area, they were a major El Capote extended family that illustrates the crucial role of the ranch in the overall community. They were truly binational in their tax contributions and government positions. Juan Manuel was educated in St. Louis, Missouri, home of many of the Anglo capitalists who immigrated to Hidalgo County. $\mathrm{He}$ spoke English and became a Methodist. At El Capote, he sponsored the first Methodist congregation and donated the first church. The minutes of the Methodist Episcopal Church 20th Annual Conference in 1878 document the fact that the families of El Capote founded the first Protestant congregation and church in Hidalgo County. Variously called "El Capote Mission" and the "Jackson Ranch Church," the congregation was credited with sponsoring the establishment of other Protestant churches in the county (Hidalgo County Historical Commission n.d.a:1, 13). The congregation also maintained the cemetery known as El Capote Ranch Cemetery on Porción 70, near the Ramirez homestead (Hidalgo County Historical Commission n.d.b:1).

The de la Viña family also played a major role in the brickmaking industry on the early Rio Grande ranch frontier. In Reynosa, Don Manuel de la Viña sponsored the construction of a major brick factory (ladrillera) during the 1840s. His sons later transmitted the knowledge across the Rio Grande into Hidalgo County. At El Capote, the de la Viña family built the first brick homes in Hidalgo County, and Manuel de la Viña owned the only brick home in Hidalgo, which was the original site of Edinburg during the 1850s. The county court used the home for court sessions under a rental arrangement. Twentieth-century census manuscripts for Hidalgo County reveal a constant presence of bricklayers and brickmakers in the area, and a brick kiln was reported at El Capote (Archivo Historico de Reynosa; Court Record Book A:18; U.S. Bureau of the Census 1900). 



\section{TESTING AND EVALUATION OF PREVIOUSLY RECORDED SITES}

Douglas K. Boyd, Amy C. Earls, Karl W. Kibler, and Andrés Tijerina

One prehistoric and three historic components at three sites (41HG153, 41HG156, and 41HG158) were specifically targeted for additional investigation after the initial survey work was completed (Kibler and Freeman 1993:64). All work conducted at these sites was in accordance with the methods described in the Proposal and Plan of Work, with two exceptions. First, since most of the project area recently had been plowed in preparation for fall planting, artifact visibility was extremely low and the artifact density was much lower than expected. Hence, the 10-x-20-m surface collection blocks proposed for sites $41 \mathrm{HG} 153$ and $41 \mathrm{HG} 158$ were not sufficient for obtaining useful samples of temporally and/or functionally diagnostic artifacts. Consequently, surface collections at both of these sites were made in long corridors, oriented parallel to the terraceedge road and slope, that were segmented into multiple collection units. Sufficient artifact samples thus were recovered by increasing the total area of the surface collection and by including the eroded roadways where surface visibility was highest.

The second deviation from the work plan stemmed from restrictions placed on the subsurface testing at 41HG153 and 41HG158 during 1993 by the agricultural firm leasing the land. Because the fields had been recently plowed and leveled in preparation for planting, no subsurface testing was allowed except within the existing roadways or terrace slopes. Unfortunately, the archival and informant evidence suggested that the house structures at these sites had been in the fields rather than near the terrace edge. While the subsurface testing did provide sufficient information to fully evaluate the archeological potential of 41HG158, 41HG153 could not be assessed adequately at the conclusion of the 1993 testing.

Additional archeological testing was required at $41 \mathrm{HG} 153$, and in consultation with the regulatory agencies and the lessee, a second phase of subsurface testing was scheduled for Summer 1994. Archeologists returned to 41HG153 in June 1994, when the field was temporarily fallow between crops, and conducted additional backhoe testing. This second phase of testing provided the necessary data for a complete National Register evaluation.

\section{HG153, GARZA RANCH NO. 1}

\section{Site Setting}

Site $41 \mathrm{HG} 153$, located on the edge of a flat alluvial terrace that is $1.0-1.2 \mathrm{~m}$ above the floodplain of the Rio Grande, consists of historic and prehistoric components (see Figure 13). The site is situated along an unimproved road that runs parallel along the edge of the terrace and extends into the agricultural field to the north. The field was recently plowed and devoid of vegetation at the time of investigation. The site covers an area 30-40 m north-south by $440 \mathrm{~m}$ east-west and lies at an elevation of 95-100 ft above mean sea level. 


\section{Previous Investigations}

This site was discovered and recorded during the 1992 survey and subsurface testing of High Probability Area 1 (Kibler and Freeman 1993:3840). Scattered historic and prehistoric artifacts were observed within the $25-\mathrm{m}$ (north-south) by 250-m (east-west) site area. Two backhoe trenches (designated as 1992-9 and 1992-10) in the site failed to provide any definite evidence of subsurface remains associated with either component, and most of the information was derived from surface-collected artifacts $(\mathrm{N}=44)$. Collected diagnostic specimens associated with the prehistoric component are the proximal end of a Starr arrow point (cf. Turner and Hester 1985:190), 1 mussel shell fragment, 5 pieces of lithic debitage, and 3 bone fragments, while 2 metal artifacts and 32 ceramic sherds associated with the historic component also were collected. Temporally diagnostic ceramics dating from the $1830 \mathrm{~s}-1860 \mathrm{~s}$ include sherds with blue-painted scalloped-rim edge decoration, transfer-printed sherds in black and blue, sherds with banded annular decorations in dark earth tones (and one sherd with a possible mocha decoration), sherds with hand-painted floral decorations, and sherds of annular yellowware. In addition, 15 sherds were identified as soft-paste utilitarian wares of probable Mexican origin.

Because of the scarcity of definable prehistoric archeological components in the Lower Rio Grande Valley, even low-artifact-density sites such as 41 HG153 are considered to have potential for addressing important research issues. The research potential of the historic component also was considered to be high since it dates to the Texas Republic and/or early American periods and represents a mid-nineteenth-century ranching site associated with El Capote. Hence, it was recommended that both components at site $41 \mathrm{HG} 153$ be considered potentially eligible for listing on the National Register of Historic Places and for designation as State Archeological Landmarks, and further testing was recommended.

\section{Work Accomplished}

Phase II investigations at 41HG153 included work on the prehistoric and historic components (Figure 25). In order to test and evaluate the prehistoric component in the western end of the site, six backhoe trenches and one 1-x-1-m unit were excavated. Investigation of the historic component included surface collection of diagnostic historic artifacts and mechanical testing. A reinspection of the site found the sparse artifact scatter extended ca. $440 \mathrm{~m}$ east-west by ca. 30$40 \mathrm{~m}$ north-south, and the site size was extended accordingly. In order to obtain a sufficient sample of historic artifacts, a $420-\mathrm{x}-30-\mathrm{m}$ section along the terrace-edge road was divided into 22 surface collection units (each $20 \times 30 \mathrm{~m}$ ). Within each unit, all of the temporally diagnostic artifacts were collected, while the nondiagnostic artifacts were classified and quantified but not collected.

The initial subsurface testing of the historic component in September 1993 consisted of a 170-m-long maintainer blade cut down the middle of the terrace-edge roadway (i.e., from the middle of Collection Unit 8 west to the east end of Collection Unit 16). The blade cut was confined to the central portion of the site where surface artifact density was highest. Because the packed clayey sediment in the road was so hard, blading could not be done horizontally and the maintainer blade was tilted at an angle (dipping ca. $20^{\circ}$ from horizontal). Numerous passes were made, each stripping off 5$10 \mathrm{~cm}$ of sediment, until the blade cut was excavated to a depth of $30-40 \mathrm{~cm}$ below the ground surface. The blading did not discover any structural remains but was stopped when it revealed 23 postholes in a linear pattern (see Features).

Since the initial phase of testing of the historic component was restricted to the roadway, a complete evaluation of the site's eligibility for inclusion on the National Register of Historic Places could not be made. In order to determine whether intact cultural deposits or features were preserved in the field, a second phase of mechanical testing was conducted in June 1994. Eleven backhoe trenches were excavated (Figure 26).

\section{Site Stratigraphy and Sediments}

Site $41 \mathrm{HG} 153$ is located on the margin of a Holocene alluvial terrace (T1 surface) overlooking an abandoned channel of the Rio Grande and modern floodplain (T0 surface) to the south (Kibler and Freeman 1993). Soils at this locality are mapped as Camargo silt loam and Camargo silty clay loam. Both are Entisols formed on alluvial 
$a$

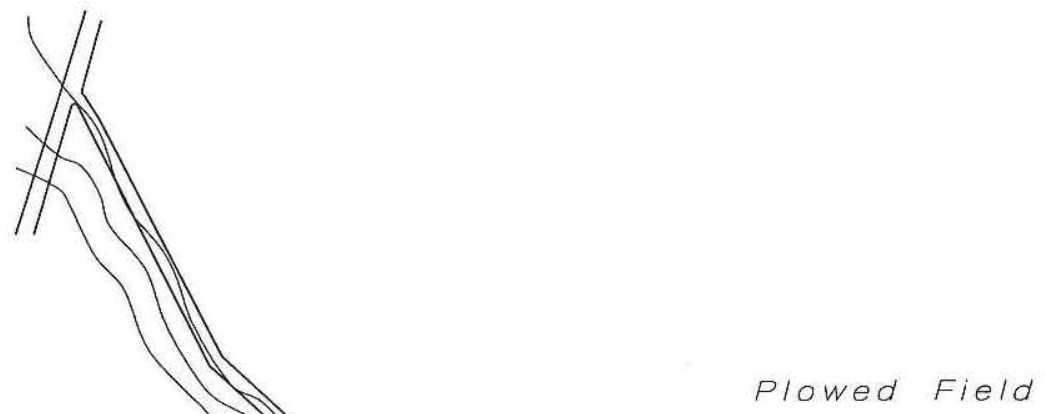

Plowed Field Edge of Terrace

$b$

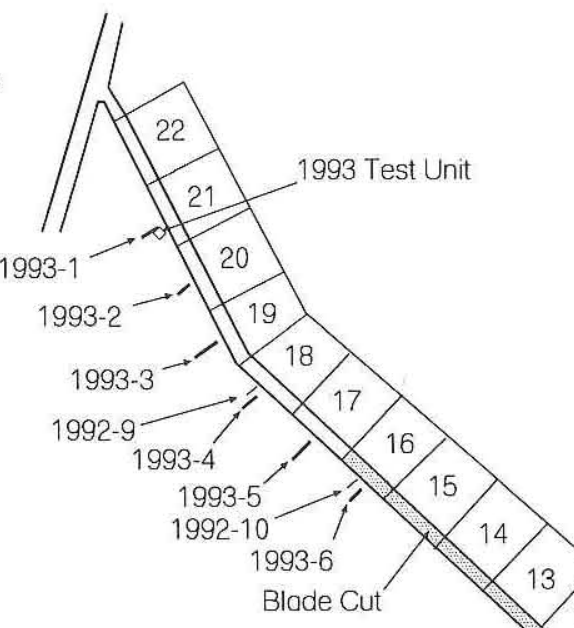

Features 1-22
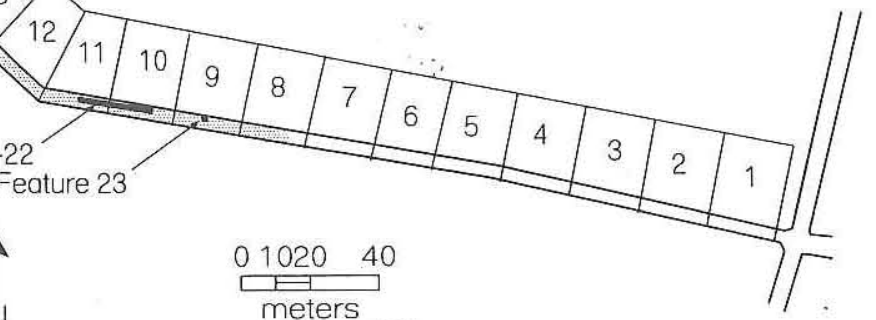

LEGEND

- Backhoe Trench

21993 Collection Unit

P\&AIISAISLH

Feature 23

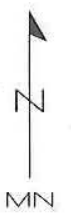

$$
\begin{aligned}
& \frac{\substack{01020 \quad 40 \\
\text { meters }}}{408} \\
& \underbrace{04080 \quad 160}_{\text {feet }}
\end{aligned}
$$

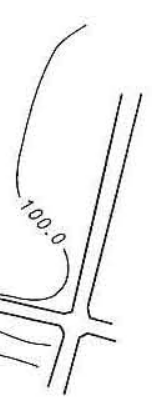

Figure 25. Site maps of 41HG153 showing (a) surface topography and (b) locations of 1992 and 1993 mechanical and hand excavations, surface collection units, and cultural features. 


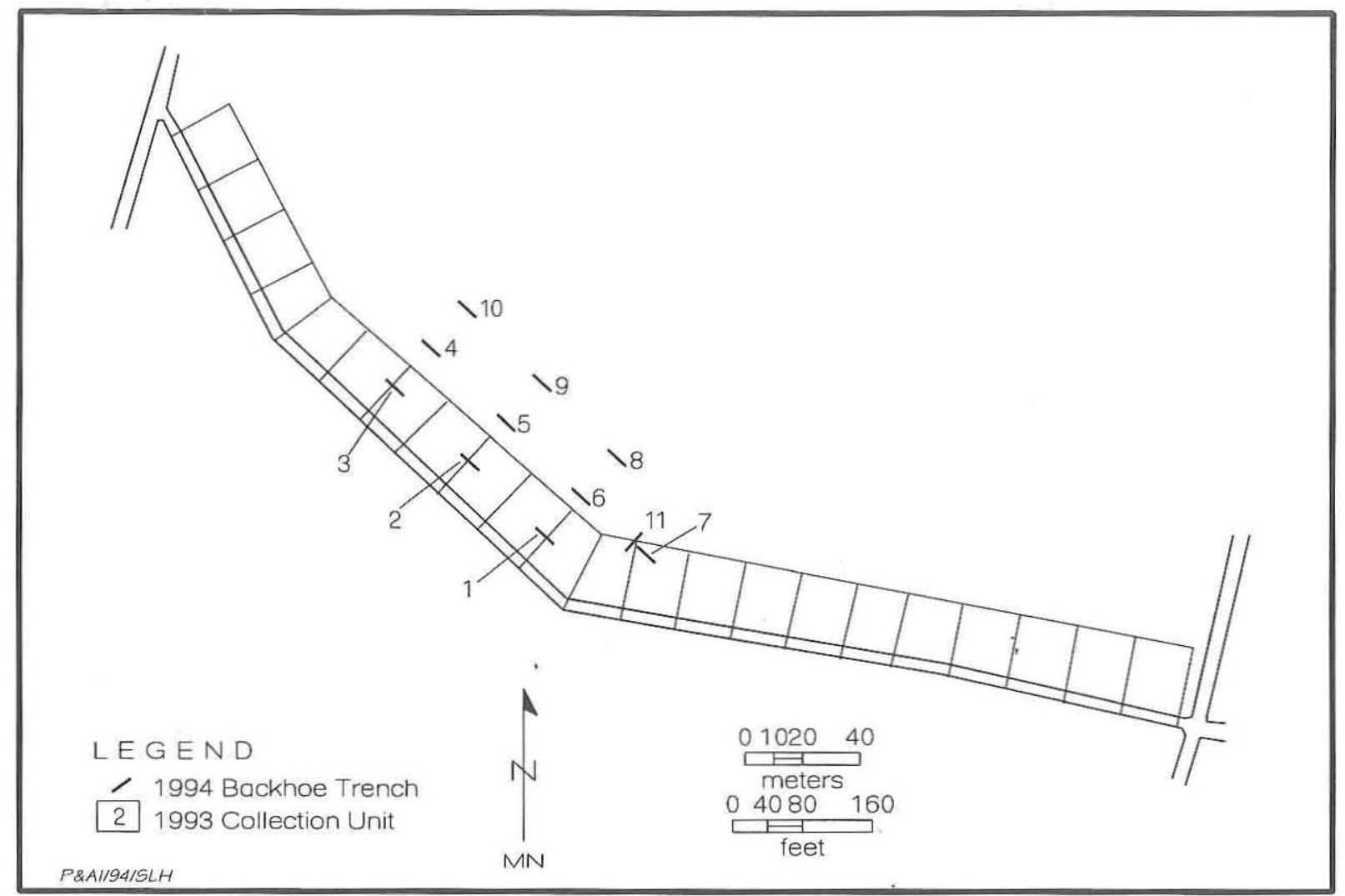

Figure 26. Site map showing locations of 1994 backhoe trenches at 41 HG153.

deposits (Jacobs 1981:171).

The stratigraphy and sediments of site 41HG153 were examined at 19 localities along 17 backhoe trenches and 1 maintainer blade cut from the T1 terrace margin and north of the terrace margin. Eight of the 19 localities are described in detail in Appendix A, while 7 of the localities are summarized and interpreted below. Four localities along two backhoe trenches and the maintainer trench along the T1 terrace margin are described below (Figure 27). Four radiocarbon assays on soil humates and charcoal from four localities provide a chronological framework for the geomorphic interpretations discussed below (Table 17).

A maintainer trench cut across the site provided a good profile and exposure of the surficial sediments. A profile segment of this blade cut, adjacent to Features 3 and 4, was recorded to a depth of $43 \mathrm{~cm}$ below the surface, and three zones were identified. Zone $1(0-24 \mathrm{~cm})$ consists of a dark grayish brown clay loam. The zone represents fill that was laid down and bladed within the last $20-30$ years for a roadbed and to maintain the integrity of the terrace edge. Zone 2 $(24-31 \mathrm{~cm})$ is a brown to dark brown sandy clay. It most likely represents a remnant of a natural levee deposit and the original, premodified T1 surface. Historic debris and artifacts, consisting of glass and ceramic fragments, are common throughout both zones. Zone 3 is a moderate medium blocky grayish brown to dark grayish brown clay with common $\mathrm{CaCO}_{3}$ filaments and represents a $2 \mathrm{Ab}$ horizon. Soil humates from $35-43 \mathrm{~cm}$ below the surface yielded a $\delta^{13} \mathrm{C}$-corrected radiocarbon assay of $1750 \pm$ 80 B.P.

Backhoe Trench 1993-5 was excavated along the slope of the terrace margin to a depth of $182 \mathrm{~cm}$ below the surface. Three zones were identified within the profile from the south end of the trench. Zone 1 is a $29-\mathrm{cm}$-thick massive dark grayish brown clay loam representing recent colluvial sediments that have eroded from the T1 surface and washed down the terrace margin. A few pieces of charcoal were observed in the zone, representing the probable remains of a recent grass 


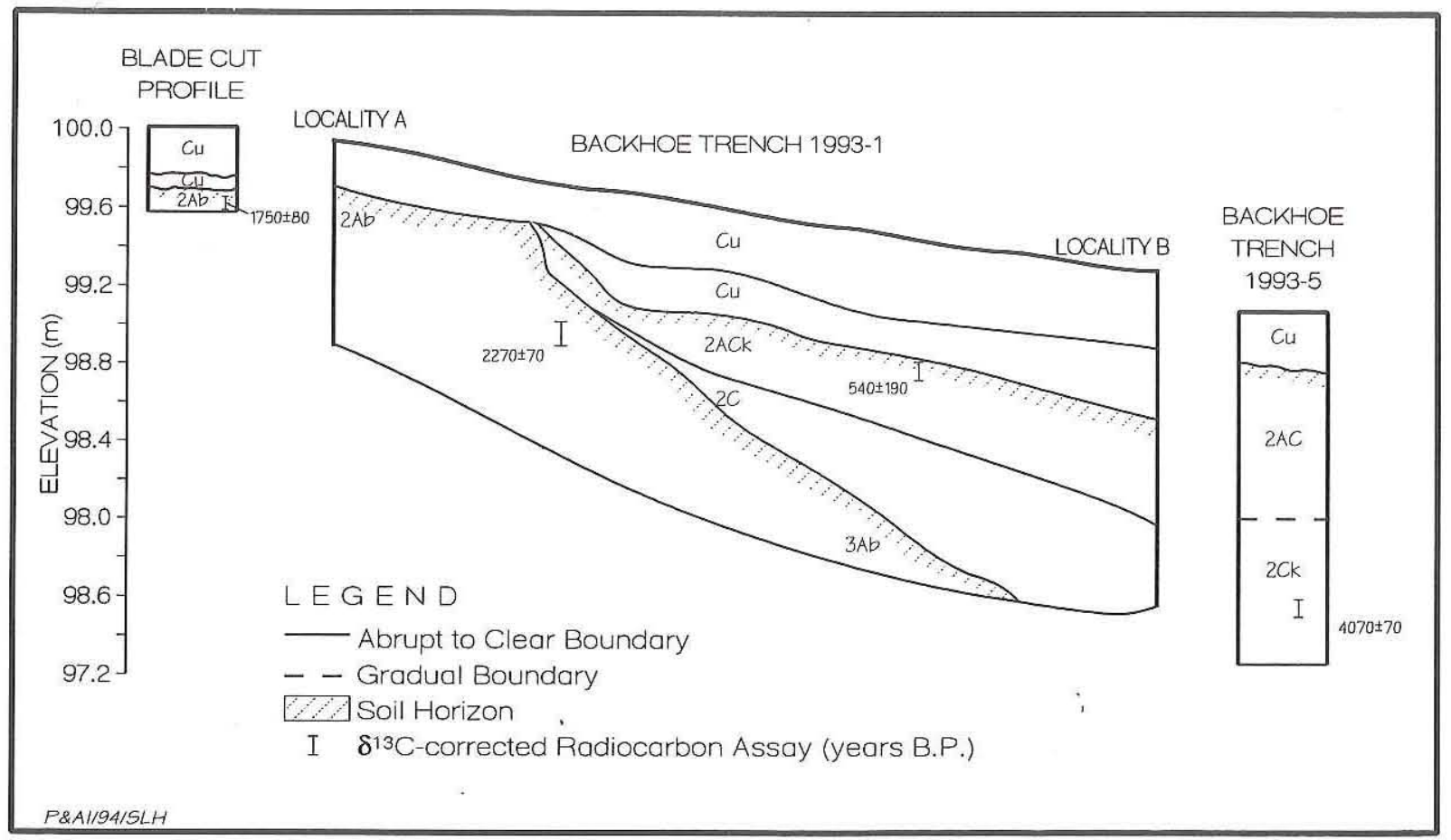

Figure 27. Geomorphic profiles of blade cut and Backhoe Trenches 1993-1 and 1993-5 along the T1 terrace margin at 41 HG153.

TABLE 17

RESULTS OF RADIOCARBON DATING ON HUMATES AND CHARCOAL, 41HG153

\begin{tabular}{|c|c|c|c|c|}
\hline Lab No. & Provenience & $\begin{array}{l}\text { Uncorrected } \\
\text { Age B.P. }\end{array}$ & $\begin{array}{l}\text { Corrected Age } \\
\text { B.P.* }\end{array}$ & $\begin{array}{l}\text { Calibrated Date/Age (Intercepts } \\
\text { and 1-Sigma Range)** }\end{array}$ \\
\hline Beta- 66446 & $\begin{array}{l}\text { Blade cut adjacent to } \\
\text { Features } 3 \text { and } 4 \text {, } \\
35-43 \mathrm{~cm} \text {, soil humates }\end{array}$ & $1640 \pm 80$ & $1750 \pm 80(-18.0)$ & $\begin{array}{l}\text { A.D. } 221(260,290,320) 406 \\
1729(1690,1660,1630) 1544 \text { B.P. }\end{array}$ \\
\hline Beta-66447 & $\begin{array}{l}\text { BHT } 1993-5 \text {, } \\
148-157 \mathrm{~cm} \text {, } \\
\text { bulk sediment }\end{array}$ & $4030 \pm 70$ & $\begin{array}{r}4070 \pm 70(-22.0) \\
\cdots\end{array}$ & $\begin{array}{l}2856 \text { (2580) } 2486 \text { B.C. } \\
4806(4530) 4436 \text { B.P. }\end{array}$ \\
\hline Beta-66448 & $\begin{array}{l}\text { BHT 1993-1, } \\
69-82 \mathrm{~cm} \text {, soil humates }\end{array}$ & $2180 \pm 70$ & $2270 \pm 70(-19.6)$ & $\begin{array}{l}395(370) 201 \text { B.C. } \\
2345 \text { (2320) } 2151 \text { B.P. }\end{array}$ \\
\hline Beta-66449 & $\begin{array}{l}\text { BHT 1993-1, } \\
70-80 \mathrm{~cm} \text {, charcoal }\end{array}$ & $560 \pm 190$ & $540 \pm 190(-26.6)$ & $\begin{array}{l}\text { A.D. } 1285(1410) 1621 \\
665(540) 329 \text { B.P. }\end{array}$ \\
\hline
\end{tabular}


or brush fire. Kibler observed a charcoal and ash lens at a similar depth within the colluvial mantle at the southern end of Backhoe Trench 1992-10 during the Phase I investigations and suggested that it may also represent a recent surface burn (Kibler and Freeman 1993:38). Zones 2 and 3 (29$182+\mathrm{cm}$ ) represent a buried or truncated Vertisol formed on muddy overbank sediments. Zone 2 is a 78-cm-thick strong medium blocky brown to dark brown clay. Few humic materials and small incipient $\mathrm{CaCO}_{3}$ nodules are dispersed throughout the zone. Zone 2 is a $2 \mathrm{AC}$ horizon and grades down to a $2 \mathrm{Ck}$ horizon (Zone 3 ). The $2 \mathrm{Ck}$ horizon is a strong medium blocky brown clay that is $75+\mathrm{cm}$ thick. A few slickensides are present on the ped faces, as are fine yellowish brown mottles. Many $\mathrm{CaCO}_{3}$ nodules are present throughout the zone. A bulk sediment sample from $148-157 \mathrm{~cm}$ below the surface yielded a $\delta^{13} \mathrm{C}$-corrected radiocarbon assay of $4070 \pm 70$ B.P.

Two localities - A and B - were recorded from Backhoe Trench 1993-1. Locality A was recorded from the northern end of the trench. The profile extended to $106 \mathrm{~cm}$ below the surface, and two zones were identified. Zone 1 is a $24-\mathrm{cm}$-thick massive to planar-laminated dark grayish brown clay. Pieces of charcoal and charcoal flecks are common throughout the zone. A few historic artifacts and debris, consisting of glass and ceramic fragments, are also present. Zone 1 is road fill laid down and bladed within the last 2030 years. Underlying the fill is the natural terrace surface, represented by Zone 2 . Zone 2 is a moderate medium blocky grayish brown clay that is $82+\mathrm{cm}$ thick and contains common small incipient $\mathrm{CaCO}_{3}$ nodules. Zone 2 is a buried or truncated Vertisol and is classified as a $2 \mathrm{Ab}$ horizon. Soil humates from $69-82 \mathrm{~cm}$ below the surface yielded a $\delta^{13} \mathrm{C}$-corrected radiocarbon assay of $2270 \pm 70$ B.P.

Locality B was recorded at the southern end of the trench. The profile extends to $173 \mathrm{~cm}$ below the surface, and five zones were identified. Zone 1 is a $40-\mathrm{cm}$-thick massive to planar-laminated dark grayish brown clay. Pieces of charcoal and charcoal flecks are common throughout the zone. A few historic artifacts and debris, consisting of glass and ceramic fragments, also are present. Zone 1 represents road fill and colluvial sediments that have washed downslope along the terrace edge and is analogous both temporally and genetically to
Zone 1 of Locality A and Zone 1 of Backhoe Trench 1993-5. Zone 1 abruptly overlies Zones 24 , which represent channel margin and channel fill deposits. Zones 2-3 $(40-101 \mathrm{~cm})$ consist of a massive brown very fine sand and a moderate medium blocky brown sandy clay, respectively. Both zones represent episodes of channel margin (i.e., natural levee) deposition; they are chronologically discrete and are separated by a weakly developed soil (2ACk horizon) formed on top of Zone 3. Charcoal from a burned tree stump at 70$80 \mathrm{~cm}$ below the surface in Zone 3 yielded a $\delta^{13} \mathrm{C}-$ corrected radiocarbon assay of $540 \pm 190$ B.P. Zone $4(101-157 \mathrm{~cm})$ is cross-stratified brown fine sand, representing a channel fill (point bar) deposit. Zone $5(157-173+\mathrm{cm})$ is a moderate medium blocky grayish brown clay with common small incipient $\mathrm{CaCO}_{3}$ nodules. A soil (3Ab horizon) formed on top of this' deposit is the lateral equivalent to the soil formed on top of Zone 2 of Locality A, conveying the notion that the overlying zones (Zones 2-4) represent an erosional inset fill capped by a recent colluvial mantle.

Three localities from three backhoe trenches north of the terrace margin and roadbed are described below, representing a west to east cross section of the site (Figure 28). Backhoe Trench 1994-4 was excavated to a depth of $134 \mathrm{~cm}$ below the surface. Three zones were identified within the profile from the west end of the trench. All three zones represent a Vertisol that has formed on the $\mathrm{T} 1$ terrace surface. Zone $1(0-42 \mathrm{~cm})$ is a dark grayish brown clay loam representing the modern plow zone (Ap horizon). Zone 2 is a $51-\mathrm{cm}$-thick mottled grayish brown clay loam. Zone 2 represents the intact portion of the A horizon, although the top of this zone appears to be slightly mixed, probably due to varying plow zone depths from year to year. This disturbance, however, is not as severe as the overlying plow zone. Zone 3 $(93-134+\mathrm{cm})$ is a brown to dark brown clay with very small incipient $\mathrm{CaCO}_{3}$ nodules. Slickensides on the ped faces are indicative of the vertisolic nature of the soil. Zone 3 is a $\mathrm{Ck}$ horizon.

Backhoe Trench 1994-5 was excavated east of Backhoe Trench 1994-4 to a depth of $145 \mathrm{~cm}$ below the surface. Four zones were identified within the profile of the south wall. Zones 1 and 2 represent recent fill that was brought in to level the field for cultivation and irrigation. Zone 1 $(0-39 \mathrm{~cm})$ is a dark grayish brown silty clay loam 


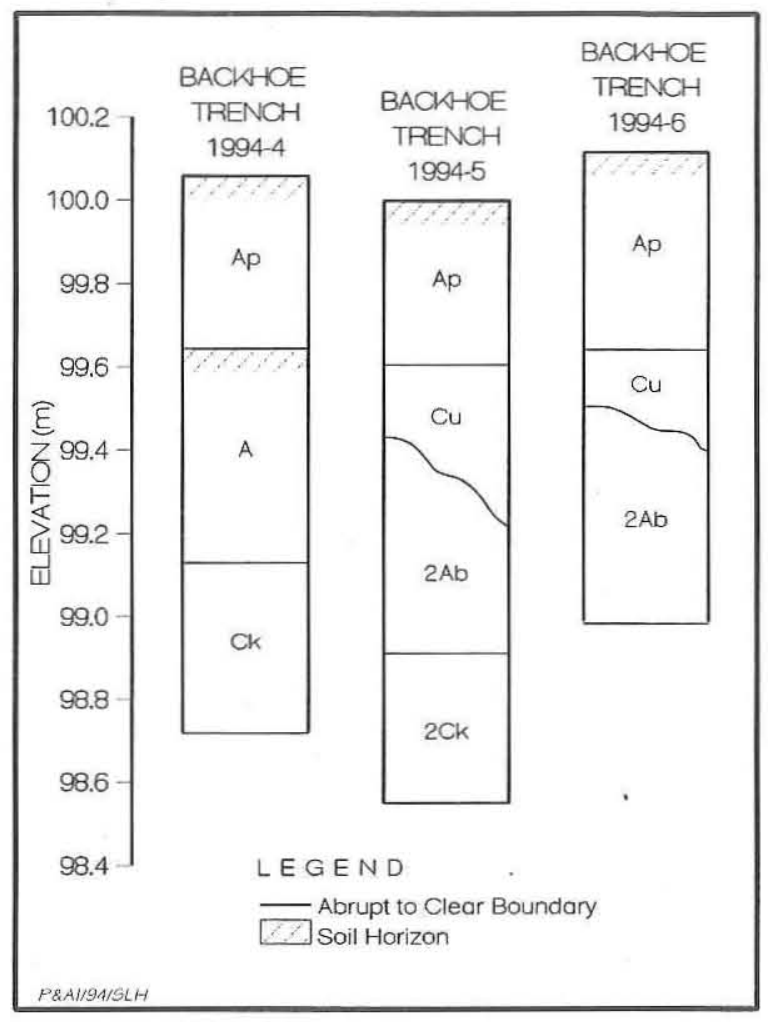

Figure 28. Geomorphic profiles of Backhoe Trenches 1994-4, 1994-5, and 1994-6 at 41HG153.

and represents the modern plow zone. Zone 2 (39$57 / 78 \mathrm{~cm}$ ) is brown silt loam. Its weak structure, flecks of charcoal, and $\mathrm{CaCO}_{3}$ filaments throughout the zone suggest that the sediments are mixed. Zone $3(57 / 78-108 \mathrm{~cm})$ is a dark grayish brown clay loam with common $\mathrm{CaCO}_{3}$ filaments, representing the original or at least the truncated $\mathrm{T} 1$ terrace surface (2Ab horizon). Zone 4 (108$145+\mathrm{cm}$ ) is a brown clay with common very small incipient $\mathrm{CaCO}_{3}$ nodules representing the $2 \mathrm{Ck}$ horizon.

Backhoe Trench 1994-6 was excavated east of Backhoe Trench 1994-5 to a depth of $113 \mathrm{~cm}$ below the surface. Three zones were identified within the profile of the south wall. Like Backhoe Trench 1994-5, Zones 1 and 2 represent recent fill that has been brought in to level the field for cultivation and irrigation. Zone $1(0-47 \mathrm{~cm})$ is a dark grayish brown clay loam and represents the modern plow zone (Ap horizon). Zone 2 (47$61 / 72 \mathrm{~cm}$ ) is a brown to dark brown silt loam. Zone $3(61 / 72-113+\mathrm{cm})$ is a dark grayish brown to grayish brown clay loam. It is a buried soil representing the original $\mathrm{T} 1$ terrace surface.
Slickensides on the ped faces are a testament to the soil's vertisolic properties.

The recent fill observed in these and other backhoe trench profiles north of the terrace margin tends to increase in thickness from west to east. It is likely that a topographic depression existed behind (north) of the levee on the terrace margin and was later filled to facilitate crop irrigation. A lens of charcoal, burned earth, and historic artifacts (see Charcoal/Ash Features) and disturbed sediments were observed below the plow zone in Backhoe Trenches 1994-7 and 1994-11. Some evidence of burning and/or disturbance (i.e., scattered charcoal, historic artifacts, and mottled sediments) also was observed in most of the other 1994 backhoe trenches. The cumulative evidence provides a strong indication that some clearing and burning of vegetation occurred prior to the landscape modification (i.e., land leveling).

The sediments and stratigraphy of all of the 41HG153 profiles constitute two geomorphic landforms: (1) the modern floodplain or the T0 surface, an erosional inset fill of predominantly channel fill and margin facies; and (2) the Holocene terrace or T1 surface, consisting mainly of overbank muds and presumably pre-late Holocene alluvial fill. The formation of these two landforms is discussed below within a chronological framework based on the four radiocarbon assays and earlier radiocarbon ages obtained by Kibler (Kibler and Freeman 1993) (Figure 29). Much of the discussion focuses on a period clearly predating both components of $41 \mathrm{HG} 153$, but it is presented not only to identify the natural site formation processes at work but also to add to and amend the previous investigations of the project area by Kibler (Kibler and Freeman 1993).

The number of alluvial fills below the T1 surface is unknown, for the top of the Pleistocene Beaumont Formation was not encountered in the trench excavations. The earliest fill encountered or recognized in the T1 terrace is 4,530 years old (calibrated age of $\delta^{13} \mathrm{C}$-corrected assay of $4070 \pm$ 70 B.P.) based on a bulk sediment radiocarbon assay from Backhoe Trench 1993-5. Since no buried soils were encountered or recognized between the 4,530-year-old fill and the natural T1 terrace surface, it is believed that the observed fill represents an aggradational episode that had commenced by at least 4530 B.P. The T1 surface appears to have been fairly stable for the last 


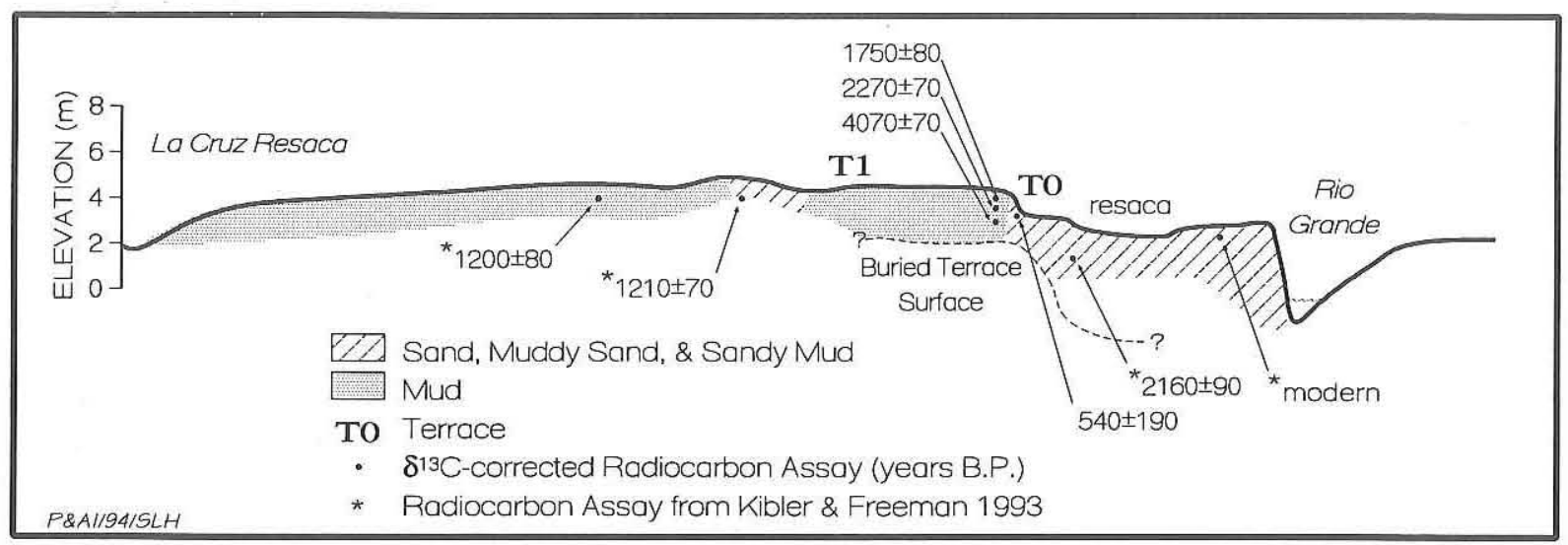

Figure 29. Generalized cross section of valley fill from the project area and $41 \mathrm{HG} 153$ with radiocarbon ages of sediment.

1,050 to 1,260 years, based on assays obtained earlier on soil humates (Kibler and Freeman 1993). From this evidence, Kibler suggested that channel incision occurred at this time and that the T1 terrace was late Holocene in age. At 41HG153, the natural T1 surface is buried by ca. $24 \mathrm{~cm}$ of road fill and up to $80 \mathrm{~cm}$ of fill north of the terrace margin in the cultivated field. Soil humates from the buried intact surface yielded a $\delta^{13} \mathrm{C}$-corrected assay of $1750 \pm 80$ B.P., suggesting that the T1 surface at $41 \mathrm{HG} 153$ has been truncated, most likely due to the grading of the current roadbed and field leveling, and then buried by fill in places. The recent result of the field leveling and clearing has been the development of a thick colluvial mantle that drapes the terrace slope and adjacent T0 surface (cf. Zone 1 of Backhoe Trench 1993-5 and Zone 1 of Backhoe Trench 1993-1).

The current investigations suggest that much of the T1 surface is still aggrading but at a much reduced rate since the construction of Falcon Reservoir and irrigation systems and levees across the valley's floodplain. It also is more likely that the T1 terrace is much older and that the recognized aggradational episode commencing prior to 4530 B.P. on the T1 terrace is the product of overbank deposition of fine sediments outside the meanderbelt and onto a much older terrace surface formed by channel entrenchment prior to 4530 B.P.

The T0 surface or modern floodplain is an aggrading meanderbelt environment. It has aggraded to within 0.8 to $1.2 \mathrm{~m}$ of the $\mathrm{T} 1$ terrace surface at $41 \mathrm{HG} 153$. The number or chronological sequence of alluvial fills below the T0 surface currently is unknown since the base of the
Holocene fill was not encountered in the backhoe trench excavations. The earliest fill encountered or recognized is 2,145 year's old, based on a radiocarbon assay obtained during the Phase I investigations (Kibler and Freeman 1993). Unlike the T1 terrace, much of the fill consists of channel fill and margin deposits rather than fine overbank sediments. Abandoned channels or resacas are well preserved, revealing the dynamic nature of a meandering fluvial environment. A radiocarbon assay on charcoal from within a natural levee deposit suggests that the active channel of the Rio Grande was in close proximity to the T1 terrace margin at $41 \mathrm{HG} 153$ as recently as A.D. 13001600 , and underlying channel fill sands indicate the channel was adjacent to the terrace edge just prior to this time period. It may have been at this time that the Rio Grande built the observed levee remnant of Zone 2 of the maintainer trench. The time-transgressive nature of laterally accreted alluvial deposits is reflected by the age difference between the 350-650-year-old natural levee deposit and a modern assay obtained from a crevasse splay deposit below the T0 surface during earlier investigations (Kibler and Freeman 1993).

The vast difference in elevation (estimated to be at least $1.7 \mathrm{~m}$ ) between the 2,145-year-old fill below the $\mathrm{T} 0$ surface and the $\delta^{13} \mathrm{C}$-corrected assay of $2270 \pm 70$ B.P. (calibrated age $=2320$ B.P.) from below the truncated $\mathrm{T} 1$ terrace surface indicates that the episode of channel incision forming the T1 terrace occurred prior to 21002300 B.P. and that valley aggradation had commenced once again by this time. This is consistent with the interpretation of the T1 terrace 
data for channel incision and terrace formation. Both interpretations suggest that high-magnitude floods or periods of high discharge probably were quite common after channel incision, as fine overbank sediments were continually deposited outside the meanderbelt and on top of the T1 surface based on the assays from soil humates postdating 4530 B.P. Such catastrophic events are fostered by the extremely low gradient and nearlevel topography of the Lower Rio Grande Valley. Prior to the construction of levees, drainage ditches, and canals, flood waters from the lower Rio Grande frequently covered much of the valley and periodically even inundated the cities of Mission, McAllen, and Pharr, which are located on a Pleistocene Beaumont Formation terrace.

Between 4530 and 2320 B.P., the depositional rate of fine overbank sediments on the T1 terrace averaged $7.0 \mathrm{~cm} /$ century and increased to $9.8 \mathrm{~cm} /$ century after 2320 B.P. This increase may not necessarily reflect climatologically controlled changes in the frequency of overbank flooding and discharge during the late Holocene but rather may be the result of a continuously aggrading channel, which through time made it more possible for lesser volumes or discharges to result in overbank flooding on the T1 terrace surface. It is most likely that recent deposition on the $\mathrm{T} 1$ surface has been severely limited since the construction of Falcon Reservoir and irrigation systems and levees across the valley's floodplain.

Channel downcutting prior to 4530 B.P. is in contrast to the 1000-1100 B.P. age for channel incision suggested earlier by Kibler (Kibler and Freeman 1993). This revised chronology for channel incision on the lower Rio Grande strongly supports a middle Holocene age for terrace formation and an increasing inuduation of the T1 surface triggered by continuous channel aggradation throughout the late Holocene. It also lends support to the argument of Brown et al. (1980:19) that sediment loads of the Rio Grande sharply decreased around 4500 B.P., which most likely would have resulted in channel entrenchment and terrace formation, as well as an increased sinuosity and a decreased channel gradient (Schumm 1977). Ultimately, other factors may have been involved, such as the culmination of xeric conditions in the middle Holocene (e.g., Bousman et al. 1990) limiting run-off and discharge, the stabilization of sea level around 4500 B.P. (Brown et al. 1980:19), and the formation of Sardinas Resaca prior to 5200 B.P. (Hall et al. 1987:57-60), which would have diverted and prevented some run-off from reaching the main channel of the Rio Grande.

\section{Geoarcheological Implications}

Although most of the preceding interpretations and discussion focus on the formation of the geomorphic environments prior to either the historic or prehistoric occupations, they identify the site formation processes operating at 41HG153 throughout the late Holocene and provide insight on the potential integrity of the prehistoric and historic components.

Clearly, much of the T1 surface throughout the late Holocene was subjected to overbank deposition of fine sediments. Such a depositional environment is inclined to preserve the archeological remains of groups previously utilizing and occupying its surface. This most likely was the situation at $41 \mathrm{HG} 153$ until recent vegetation clearing and land modifications were carried out. These modifications truncated portions of the original T1 terrace surface in the western part of the site and buried other parts, along the terrace margin (roadbed) and the central and eastern parts of the site, under $25-80 \mathrm{~cm}$ of fill. Radiocarbon dates (1630-1690 B.P.) from the underlying intact terrace surface predate both components identified at the site, making the possibility of intact cultural deposits of either component at $41 \mathrm{HG} 153$ very limited.

\section{Historic Component}

\section{Site History}

Site 41HG153 is located in Porción 69, a grant made to Juan José Hinojosa by the crown of Spain on October 22, 1767 (Deed Record C:586-587). Hinojosa owned Porción 69 until September 3, 1794, after which owners included José Matias Cavazos, Lino Cavazos, and Rafael Anaya, who purchased the grant on April 16, 1823 (Deed Record E:560-562).

Porción 69 remained in the ownership of the Anaya family and their relatives, including the Garzas and Cantus, and they were living there in the 1850s when the grant was confirmed to Hinojosa, his heirs and assigns by the State 
Legislature (Deed Record A:304-305, C:586-587). The area then went by the name "El Capote" and was the location of a sizable ranch community which was roughly bordered on the north by a military road that ran east-west and was used regularly by the U.S. Army and other armed groups for logistical purposes. To the south, on the Rio Grande, landmarks included a ford which most likely was one of the few that the Spaniards crossed on their way to the salt lakes in northern Hidalgo County. In addition, there was a ferry that was registered with the county from 1852 to the turn of the century when the landing was used by steamboats and the ferry by armed groups crossing military materiel. The ferry was registered as "One at the Capote Rancho. One Batteaux and Skiff. Ferry Boat to pass between Edinburg and Reynosia [sic]" (Court Record Book A:3-18).

Artifacts from site 41HG153 suggest an occupation date by the second quarter of the nineteenth century, and historic records indicate that by midcentury the families most strongly associated with Porción 69 were the Anayas and Garzas. In addition, family members regularly represented the precinct throughout the latter half of the nineteenth century on county boards and commissions, such as Valentin Garza, who served as Grand Jury member in March, 1867 (Court Record Book I:63). By the last third of the nineteenth century, occupants of the area near the site were members of the Garza family.

In 1898-1900, Hidalgo County Sheriff John Closner and his partner, James B. Wells, acquired acreage including $41 \mathrm{HG} 153$ from members of the Garza family and other property owners (Deed Record I:56-57). In return, Closner and Wells acknowledged the title claimed by Guillermo Garza, Alejandro Garza, and Isabel Garza de Guajardo (the heirs of Valentin Garza), stating that the tract was "now, and for many years ... past, actually held, occupied and possessed by the said Guillermo Garza, and others, Heirs, of the said Valentin Garza, deceased" (Deed Record J:111113). Closner and Wells sold 11,647 acres of their holdings in Porción 69 to J. P. Withers of Kansas City, Missouri, in 1902 (Deed Record J:501-504), who then deeded a 380-acre plot extending south from the Military Road to the river to Wyan Nelson of the Nelson Mortgage Company of Kansas City. After his death, Nelson's trustees, French L. Nelson, Arthur W. Nelson, and Thomas
W. Nelson obtained a warranty deed of transfer to the 380 acres in 1940 (Deed Record 467:403). They sold it to Eduardo G. Vela for $\$ 4,612$ in 1942 (Deed Record 499:372). The large plot was renamed "El Peso" by Vela, reportedly because he found a silver peso when he dug a well on the property (Vela 1993). Vela's widow, Francisca Recio Vela, is the present trustee and owner of the 380-acre plot and leases it to a farmer (Tax Records).

Informants remember seeing the original Garza Ranch headquarters in ruins early in the twentieth century, and they attribute the site to Guillermo Garza, Sr. (Garza and Garza 1993; Garza et al. 1992), who was born $1860-1865$ and was the first Garza to own land at El Capote. Descendants of Guillermo Garza, Sr. (see Figure 24) include several sons and grandsons associated with various sites at El Capote: José Garza at 41HG164, Tirso Garza at 41HG166, Roberto Garza and Nestor Garza, Jr., at 41HG165, and Guillermo Garza, Jr., at unrecorded Garza Ranch No. 2 (see Chapter 5). Since there are two sites that are called the Guillermo Garza Ranch, 41HG153 is informally called Garza Ranch No. 1.

\section{Features}

Twenty-four cultural features were found during subsurface testing at 41HG153: 23 are postholes exposed by the maintainer in 1993, and 1 is a charcoal/ash lens exposed in two backhoe trenches in 1994. While these features are cultural (i.e., manmade), they all are of recent origin and are not associated with the historic occupation of Garza Ranch No. 1. They apparently are associated with the farm and ranch activities during the past 50 years.

\section{POSTHOLES}

Excavation of the mechanical blade cut exposed in plan view 23 circular stains oriented in a linear pattern parallel to the terrace-edge road (Figure 30a). Each of these circular stains, designated as Features $1-23$, is $20-30 \mathrm{~cm}$ in diameter and appeared at a depth of $25-30 \mathrm{~cm}$ below the surface (Figure $30 \mathrm{~b}$ ). Twenty-two of these features are clustered together, generally spaced about $1 \mathrm{~m}$ apart, while one feature is located ca. $18 \mathrm{~m}$ east of the others (see Figure 25). 

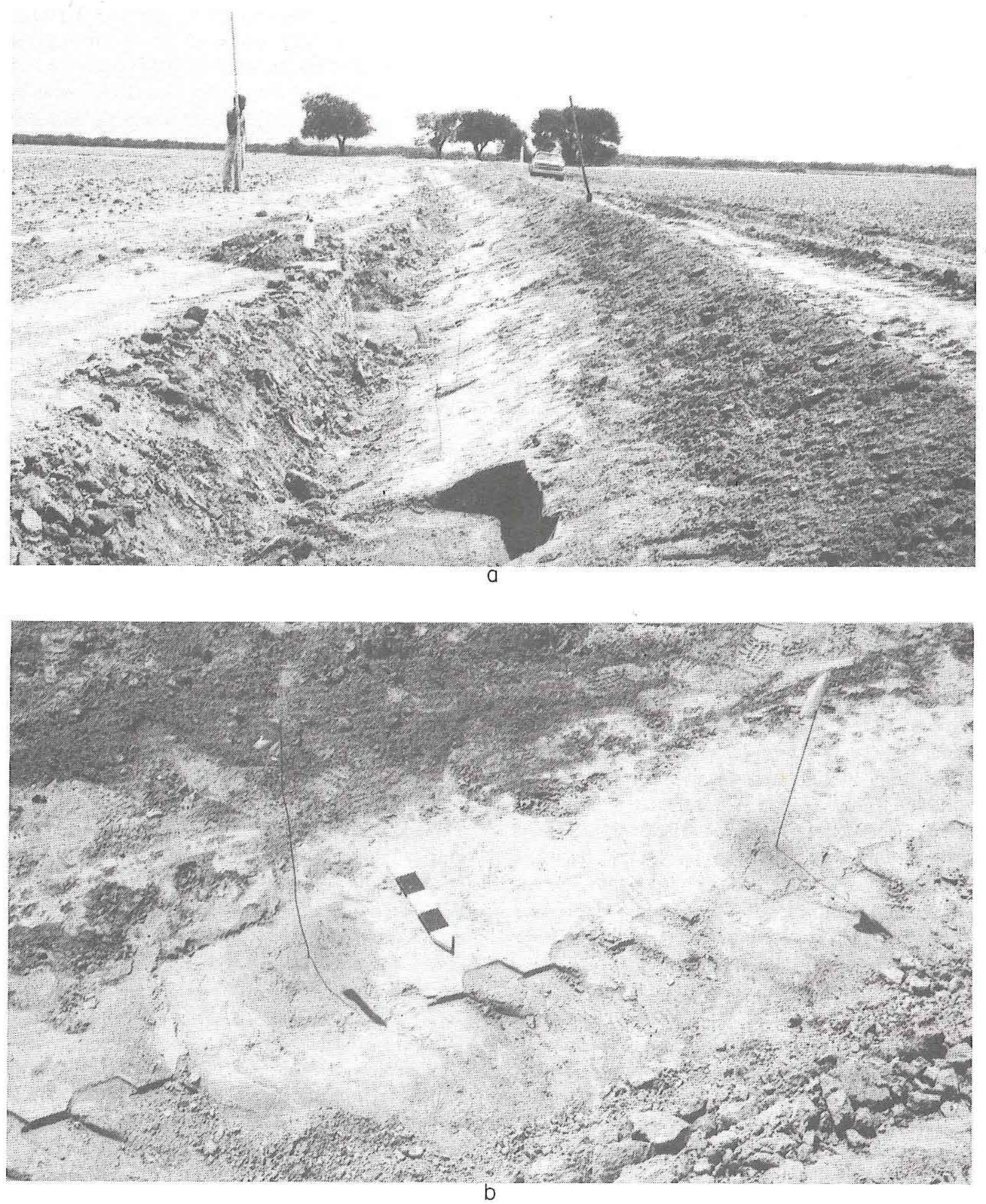

Figure 30. Posthole features exposed in maintainer blade cut at $41 \mathrm{HG} 153$. (a) View to east of postholes exposed in a linear pattern in the blade cut; pin flags mark each feature, and trees in the background are at $41 \mathrm{HG} 152 ;(b)$ overhead view to south of posthole Features 16 (right) and 17 (left). 
These features were not excavated but were exposed, drawn, and photographed in plan view.

Because of their size and shape and the nature of their fill, these features are interpreted as postholes that once contained wooden posts. The fill inside 14 of these features consisted only of dark mottled sediment $(n=5)$ or dark mottled sediment containing charcoal flecks and/or bone fragments $(n=9)$. The former presence of wooden posts was indicated by rotted wood and/or charred wood fragments in nine of the features, and six of these had actual remnants of posts whose outlines could be discerned within the posthole. One of these postholes had vertical bones (one of which was identified as a bovid metapodial) next to a charred post remnant, suggesting that the bones served as shims. Another feature had a circular ferrous stain (i.e., rust) adjacent to a remnant post, indicating that a vertical iron pipe may have been placed in the hole as a shim. Clearly, the logical interpretation for these features is that they represent a buried fenceline of wooden posts.

The stratigraphic profile of the roadway blade cut in the vicinity of the postholes is revealing (see Appendix A, 41HG153 Blade Cut profile). There is no evidence of the postholes in the upper clay loam at $0-24 \mathrm{~cm}$ below the surface (Zone 1), but they are intrusive through a lighter colored band of sandy clay at $24-31 \mathrm{~cm}$ (Zone 2) and into a darker clay (Zone 3) that appears at $31 \mathrm{~cm}$ below the surface. Zone 1 clearly represents an artificial fill that was brought in to cap the road, while Zones 2 and 3 represent intact natural deposits (see Sediments and Stratigraphy). Zone 2 may represent a natural levee deposit along the terrace edge, and the top of this stratum represents the ground surface at the time that the fence was constructed. The overlying sediment must have been added after the fence was removed, and the capping of the road presumably was done in recent times, probably in conjunction with modern agricultural practices (i.e., land leveling).

Aerial photographs support an interpretation that the fenceline and the road are twentiethcentury features. Although the land surrounding the site had not been cleared of vegetation at the time, a 1939 USDA-ASCS aerial photograph shows a straight cleared path along the edge of the terrace (see Figure 4). Since the series of postholes is in the same location, the cleared path in the aerial photograph presumably denotes the location of a fenceline. This same fenceline apparently existed until quite recently since an aerial photograph taken in 1975 by the Soil Conservation Service (Jacobs 1981:Sheet 115) shows that the surrounding fields had been cleared but that a straight thin strip of vegetation was left along the terrace edge. Because this vegetation row is in the same location as the cleared path in the earlier airphoto, it is reasonable to assume that it represents the same fenceline. Thus, the fence must have been removed sometime after 1975, but it is not known when it was constructed. It is unlikely, however, that its construction dates to the nineteenth-century occupation of the site.

\section{CHARCOAL/ASH LENS}

The charcoal/ash lens was first encountered at ca. 45-67 cm below the surface in the west end of Backhoe Trench 1994-7. In profile, it appeared as a $0-17-\mathrm{cm}$-thick wedge of black sediment containing considerable charcoal and white ash (the latter was confined mainly to the upper portion of the feature). The charcoal/ash lens had been truncated by the $45-50-\mathrm{cm}$-thick plow zone, but the underlying sediments were mottled and appeared to be disturbed to a depth of ca. $110 \mathrm{~cm}$ below the surface. One earthenware sherd was found in situ at $80 \mathrm{~cm}$ below the surface in the disturbed lower zone below the feature. The disturbed lower zone was confined to the area immediately below the feature, and intact alluvial clay sediments were observed below $110 \mathrm{~cm}$. Elsewhere in Backhoe Trench 1994-7 (i.e., east of the charcoal/ash feature), the stratigraphic profile revealed no evidence of burning or disturbance below the plow zone, which was immediately on top of the intact alluvial clays.

The charcoal/ash lens was barely clipped by Backhoe Trench 1994-7, and its westward extent was unknown. In order to determine the feature's horizontal extent, Backhoe Trench 1994-11 was excavated just to the west of and perpendicular to Backhoe Trench 1994-7, leaving a 1-x-1-m section intact in between. A small segment of the feature was cross-sectioned in the east wall of Backhoe Trench 1994-11, but the feature was not observed in the west wall. The profile along the east wall of Backhoe Trench 1994-11 revealed that the lens of dark sediment, charcoal, and ash was only $10 \mathrm{~cm}$ thick at ca. $40-50 \mathrm{~cm}$ below the 
surface. This profile also confirmed that there was a disturbed zone below the feature that extended to ca. $75 \mathrm{~cm}$ below the surface. Thus, the feature was determined to be a rather large lens (its maximum dimension is estimated to be $2-2.5 \mathrm{~m}$ ) of varying thickness (up to ca. $20 \mathrm{~cm}$ ), but its overall shape (in plan view) is unknown.

To reveal more about the nature of this feature, a 1-m-wide, 20-cm-thick strip was hand excavated to a depth of $90 \mathrm{~cm}$ along the east wall of Backhoe Trench 1994-11. Although some artifacts were observed in and below the burned zone (see Artifacts Collected and Observed), their occurrence is considered to be fortuitous. The nonartifactual materials that were observed, however, are quite revealing. While charcoalstained sediment and irregular chunks of charcoal were ubiquitous, many charred pieces were intact segments of twigs and branches. In addition, partially burned and unburned pieces of wood also were noted, including some branch fragments with intact bark. Lumps of white ash were presented also, but they were mainly confined to the upper part of the feature. The concentration of white ash near the top of the feature suggests in situ burning and complete oxidation of the uppermost wood.

Because of the excellent preservation of the perishable materials (i.e., fine ash and wood), this feature clearly represents a burning episode. Since much of the burned material is fragments of woody vegetation, it is reasonable to assume that this burned feature is associated with modern clearing of the land for agricultural purposes. Based on the aerial photographs, the area was cleared of vegetation between 1939 and 1975 . If this is correct, then the charcoal/ash stain is between 19 and 55 years old. This age estimate appears to be consistent with the presence of perishable materials.

\section{Artifacts Collected and Observed}

Ninety-four artifacts were observed but not collected (Table 18). These consist of 82 nondiagnostic surface artifacts found in the 1993 surface collection units and recorded in the field and 12 specimens found during the 1994 subsurface testing. A total of 220 selected artifacts (199 ceramic, 13 glass, and 8 bone specimens) collected from the 1993 surface collection units are described below.

\section{CERAMICS}

One hundred ninety-nine sherds representing 123 vessels were collected from this site. Wares are 34 coarse-paste earthenware, 13 refined-paste earthenware, 3 yellowware, 145 white earthenware, 2 semivitreous whiteware, 1 ironstone, and 1 stoneware sherds. The single stoneware is a bottle body sherd with a tan-colored lead-glazed exterior and unglazed interior. This sherd is probably from a ginger beer/ale-type bottle which may have contained ale, stout, or beer and probably was imported from England or Scotland. The yellowish brown color (10YR 5/6) matches two-color examples described by Banks (1983:79-87) from the 1846-1867 Brazos Santiago occupation, with the upper half dipped into a ferruginous solution before the final colorless (lead) glaze was applied. The two-color bottles date at least from the 1840s to the end of the nineteenth century (Wilson 1981:7-10).

The coarse-paste earthenwares represent 22 vessels. Three vessels have colorless lead glazes on the interior and exterior or only on one face. Two additional orange vessels, one a possible milk pan, have colorless lead-glazed interiors. One of the vessels is a thin-rimmed chocolatera (chocolate pot; Figure $31 a$ ) with a brown band at the rim. This vessel has the shape, thin walls, white and brown mineral temper, and brown banding typical of Galera ware. Galera ware was moldmade in western Mexico and is found on Texas sites dating from 1750 to the early 1800 s; similar wares are still being made in Jalisco (Dial 1992:34; Fox 1986:111, 116). Three vessels have an orange to gray paste with a green-colored lead glaze on the gray face of the sherd. Another vessel with orange to gray paste has an immature, pocked gray glaze on the gray interior face. Thirteen vessels are unglazed. These are six orange vessels, one gray and one buff to gray jar, three orange to gray vessels, one buff vessel with a dark gray core, and one orange to brown vessel.

Seven refined earthenware vessels with cream to white glazes are represented. Three sherds possibly representing a single redware vessel have dark green and yellow, orange or rust, and light green paint (Figure $31 b$ ). These vessels resemble tin-glazed earthenwares, particularly Guanajuato type, or majolica in their cream-colored glazes and green and rust floral and band designs but have 


\begin{tabular}{|c|c|c|}
\hline \multicolumn{3}{|c|}{$\begin{array}{c}\text { TABLE } 18 \\
\text { ARTIFACTS OBSERVED AT } 41 \mathrm{HG} 153\end{array}$} \\
\hline \multicolumn{3}{|r|}{ Surface Artifacts } \\
\hline Surface Collection Unit & Material Class & No. and Type of Artifact \\
\hline Unit 1 & - & None \\
\hline Unit 2 & - & None \\
\hline Unit 3 & Ceramic & 1 undecorated whiteware sherd \\
\hline Unit 4 & Ceramic & 1 undecorated whiteware sherd \\
\hline Unit 5 & Ceramic & 1 undecorated whiteware sherd \\
\hline Unit 6 & Ceramic & 2 undecorated whiteware sherds \\
\hline Unit 7 & $\begin{array}{l}\text { Ceramic } \\
\text { Concrete }\end{array}$ & $\begin{array}{l}5 \text { undecorated whiteware sherds } \\
1 \text { curved fragment (probably irrigation pipe)* }\end{array}$ \\
\hline Unit 8 & $\begin{array}{l}\text { Ceramic } \\
\text { Glass }\end{array}$ & $\begin{array}{l}5 \text { undecorated whiteware sherds } \\
1 \text { clear container fragment (solarized) } \\
1 \text { aqua bottle base fragment }\end{array}$ \\
\hline Unit 9 & $\begin{array}{l}\text { Ceramic } \\
\text { Glass }\end{array}$ & $\begin{array}{l}17 \text { undecorated whiteware sherds } \\
1 \text { clear container fragment } \\
1 \text { aqua container fragment } \\
1 \text { brown bottle base with embossed stippled design (beer bottle)* }\end{array}$ \\
\hline Unit 10 & Ceramic & 3 undecorated whiteware sherds \\
\hline Unit 11 & $\begin{array}{l}\text { Ceramic } \\
\text { Glass }\end{array}$ & $\begin{array}{l}7 \text { undecorated whiteware sherds } \\
1 \text { brown bottle base fragment (beer bottle)* }\end{array}$ \\
\hline Unit 12 & Ceramic & 3 undecorated whiteware sherds \\
\hline Unit 13 & Ceramic & 10 undecorated whiteware sherds \\
\hline Unit 14 & Ceramic & 7 undecorated whiteware sherds \\
\hline Unit 15 & $\begin{array}{l}\text { Ceramic } \\
\text { Glass }\end{array}$ & $\begin{array}{l}3 \text { undecorated whiteware sherds } \\
1 \text { clear container fragment (solarized) } \\
1 \text { clear container fragment* }\end{array}$ \\
\hline Unit 16 & Ceramic & 2 undecorated whiteware sherds \\
\hline Unit 17 & -- & None \\
\hline Unit 18 & Ceramic & 1 undecorated whiteware sherd \\
\hline Unit 19 & Ceramic & 2 undecorated whiteware sherds \\
\hline Unit 20 & Concrete & 1 curved fragment (probably irrigation pipe)* \\
\hline Unit 21 & Ceramic & 1 undecorated whiteware sherd \\
\hline Unit 22 & Ceramic & 1 undecorated whiteware sherd \\
\hline
\end{tabular}




\begin{tabular}{|c|c|c|c|}
\hline \multicolumn{4}{|c|}{ Table 18 , continued } \\
\hline \multicolumn{4}{|c|}{ Subsurface Artifacts } \\
\hline $\begin{array}{l}\text { Backhoe } \\
\text { Trench No. }\end{array}$ & Provenience in Trench & $\begin{array}{l}\text { Material } \\
\text { Class }\end{array}$ & No. and Type of Artifact \\
\hline $1994-1$ & $\begin{array}{l}\text { Found in trench fill, depth } \\
\text { unknown }\end{array}$ & Ceramic & $\begin{array}{l}1 \text { whiteware cup handle fragment with blue transfer- } \\
\text { printed decoration }\end{array}$ \\
\hline $1994-6$ & Found in trench fill, $0-47 \mathrm{cmbs}$ & Ceramic & 1 whiteware sherd with red transfer-printed decoration \\
\hline $1994-7$ & $\begin{array}{l}\text { Found in situ in west wall at } \\
80 \mathrm{cmbs} \text { in disturbed zone below } \\
\text { charcoal/ash lens feature }\end{array}$ & Ceramic & $\begin{array}{l}1 \text { brown coarse-paste earthenware sherd, colorless, } \\
\text { lead glaze on one face }\end{array}$ \\
\hline \multirow[t]{4}{*}{$1994-11$} & $\begin{array}{l}\text { Found in trench fill, depth } \\
\text { unknown }\end{array}$ & Ceramic & $\begin{array}{l}1 \text { white sherd (probable plate fragment) with scalloped } \\
\text { rim and green feather-and-plume edge decoration }\end{array}$ \\
\hline & $\begin{array}{l}\text { Found in test excavation of } \\
\text { charcoal/ash feature, depth } \\
\text { unknown }\end{array}$ & Ceramic & 1 red coarse-paste earthenware sherd, unglazed \\
\hline & $\begin{array}{l}\text { Found in test excavation of } \\
\text { charcoal/ash feature, within feature } \\
\text { zone at } 40-50 \mathrm{cmbs}\end{array}$ & Ceramic & $\begin{array}{l}1 \text { whiteware sherd, undecorated } \\
1 \text { brown coarse-paste earthenware rim sherd with hint } \\
\text { of light-colored glaze }\end{array}$ \\
\hline & $\begin{array}{l}\text { Found in test excavation of } \\
\text { charcoal/ash feature, below feature } \\
\text { zone at } 60-65 \mathrm{cmbs}\end{array}$ & $\begin{array}{l}\text { Ceramic } \\
\text { Metal }\end{array}$ & $\begin{array}{l}1 \text { brown coarse-paste earthenware rim sherd, unglazed } \\
1 \text { red coarse-paste earthenware sherd, unglazed } \\
1 \text { red refined earthenware sherd with white tin glaze } \\
1 \text { whiteware sherd with blue transfer-printed decoration } \\
1 \text { rusted iron fragment }\end{array}$ \\
\hline
\end{tabular}

orange to buff instead of the deep red pastes described as typical of this type (Dial 1992:37). Guanajuato sherds are common on early nineteenth-century sites in San Antonio (Fox 1986:111). A buff vessel has green paint. An orange vessel has a yellow rim band bordered with brown stripes. A pink earthenware vessel is represented by an undecorated sherd. A red earthenware vessel has a blue rim band covering the rim and $1 / 8$ inch into the interior in a manner similar to blue thickline floral-decorated whitewares. Another redware is decorated with green, yellow, brown, and black decoration of unknown pattern. Another redware has a colorless lead glaze over a white and brown clay slip.

Three yellowware vessels are represented. The two undecorated vessels are a large yellowcolored lead-glazed footed bowl and a creamcolored vessel with a colorless lead glaze. The decorated yellowware has tan and yellow bands on a buff earthenware.

Whiteware decoration types are edged, annular, underglaze hand painted, sponge stamped, transfer printed, molded, molded and painted, and floral decal (Table 19). Undecorated whiteware plate, cup, bowl, and mug sherds that may represent undecorated portions of decorated vessels are not counted as additional vessels. An ironstone cup, a semivitreous whiteware vessel (cup?), a white earthenware bowl, and three saucers do represent additional vessels.

Twelve edge-decorated vessels are represented. Four feather (simple outlined feather; Figure $32 a$ ) or plume (ornate, scalloped-edge feather) and three shell (Figure $32 b-d$ ) patterns are present in blue, and one feather (Figure 32e), three shell (Figure $32 f, g$ ), and one unknown patterns are present in green. Edged ceramics from this site include those in which the painted inner edge is uneven or feathered and those in which the painted 


\begin{tabular}{|c|c|c|c|}
\hline \multicolumn{4}{|c|}{$\begin{array}{c}\text { TABLE } 19 \\
\text { E CERAMIC DECORATION TYPES, } 41 \text { HG } 153\end{array}$} \\
\hline $\begin{array}{l}\text { Decoration } \\
\text { Type }\end{array}$ & Pattern & Color & Vessel Form \\
\hline Edged & $\begin{array}{l}\text { plume } \\
\text { scroll and feathers } \\
\text { feather and plume } \\
\text { dot and feather } \\
\text { shell, straight inner edge } \\
\text { shell, uneven inner edge } \\
\text { feather and plume } \\
\text { shell, straight inner edge } \\
\text { shell, uneven inner edge } \\
\text { plume? } \\
\text { grape and leaf } \\
\text { fan }\end{array}$ & $\begin{array}{l}\text { blue } \\
\text { blue } \\
\text { blue } \\
\text { blue } \\
\text { blue } \\
\text { blue } \\
\text { green } \\
\text { green } \\
\text { green } \\
\text { green } \\
\text { green } \\
\text { - }\end{array}$ & $\begin{array}{l}\text { plate } \\
\text { plate } \\
\text { plate } \\
\text { plate } \\
\text { plate } \\
2 \text { plates } \\
\text { plate } \\
2 \text { plates } \\
\text { plate } \\
\text { plate } \\
\text { unknown } \\
\text { plate }\end{array}$ \\
\hline Annular & $\begin{array}{l}\text { banded } \\
\text { banded and impressed lines } \\
\text { banded and impressed circles } \\
\text { banded and impressed } \\
\text { crosshatching } \\
\text { banded and impressed } \\
\text { (unknown design) } \\
\text { impressed hearts } \\
\text { marbleized swirl } \\
\text { marbleized with swirly dots } \\
\text { swirly dots }\end{array}$ & $\begin{array}{l}\text { yellow } \\
\text { dark brown and blue } \\
\text { dark brown } \\
\text { dark brown and yellow } \\
\text { blue } \\
\text { tan and blue } \\
\text { dark brown band, green lines } \\
\text { dark brown and tan bands, green lines } \\
\text { dark brown and tan bands, green çircles } \\
\text { dark brown and olive bands, green } \\
\text { crosshatching } \\
\text { dark brown band, green impressed } \\
\text { blue } \\
\text { brown, tan, blue } \\
\text { brown and tan } \\
\text { brown, tan, blue }\end{array}$ & $\begin{array}{l}\text { unknown } \\
2 \text { bowls, } 1 \text { saucer, } 1 \text { unknown } \\
2 \text { bowls } \\
\text { bowl } \\
\text { unknown } \\
\text { unknown } \\
\text { bowl } \\
\text { unknown } \\
\text { bowl } \\
\text { unknown } \\
\text { unknown } \\
\text { unknown } \\
\text { unknown } \\
\text { unknown } \\
\text { unknown }\end{array}$ \\
\hline Annular? & dendritic/swirl & brown and $\tan$ & unknown \\
\hline $\begin{array}{l}\text { Underglaze } \\
\text { hand painted }\end{array}$ & $\begin{array}{l}\text { thickline floral } \\
\text { thickline floral? } \\
\text { fineline floral }\end{array}$ & $\begin{array}{l}\text { blue } \\
\text { blue and red } \\
\text { green and black } \\
\text { red and green } \\
\text { red } \\
\text { yellow and tan } \\
\text { dark green and yellow } \\
\text { blue and tan } \\
\text { blue, olive, and tan } \\
\text { green, yellow, gold } \\
\text { blue } \\
\text { green and black } \\
\text { brown, tan, gold } \\
\text { blue, olive, yellow, black } \\
\text { blue and black } \\
\text { black } \\
\text { orange and brown } \\
\text { yellow, blue, green, black }\end{array}$ & $\begin{array}{l}3 \text { saucers, } 3 \text { shallow bowls, } \\
2 \text { cups } \\
\text { cup } \\
\text { plate } \\
\text { plate } \\
\text { saucer } \\
\text { saucer } \\
\text { unknown } \\
\text { unknown } \\
\text { saucer } \\
\text { saucer } \\
\text { saucer? } \\
2 \text { unknown } \\
\text { unknown } \\
\text { saucer } \\
\text { unknown } \\
\text { saucer } \\
\text { unknown } \\
\text { unknown }\end{array}$ \\
\hline
\end{tabular}




\begin{tabular}{|c|c|c|c|}
\hline \multicolumn{4}{|c|}{ Table 19, continued } \\
\hline $\begin{array}{l}\text { Decoration } \\
\text { Type }\end{array}$ & Pattern & Color & Vessel Form \\
\hline $\begin{array}{l}\text { Underglaze } \\
\text { hand painted, } \\
\text { continued }\end{array}$ & - & blue & unknown \\
\hline $\begin{array}{l}\text { Sponge } \\
\text { stamped }\end{array}$ & floral & green & unknown \\
\hline $\begin{array}{l}\text { Transfer } \\
\text { printed }\end{array}$ & $\begin{array}{l}\text { geometric } \\
\text { floral } \\
\text { unidentified } \\
\text { unidentified floral } \\
\text { unidentified floral } \\
\text { Canova } \\
\text { unidentified } \\
\text { unidentified floral } \\
\text { unidentified floral } \\
\text { unidentified } \\
\text { unidentified } \\
\text { unidentified floral }\end{array}$ & $\begin{array}{l}\text { blue } \\
\text { blue } \\
\text { blue } \\
\text { deep blue } \\
\text { blue } \\
\text { flow blue } \\
\text { black } \\
\text { black } \\
\text { flow black } \\
\text { red } \\
\text { red } \\
\text { purple } \\
\text { purple }\end{array}$ & $\begin{array}{l}\text { plate } \\
\text { plate } \\
1 \text { plate, } 2 \text { saucers } \\
\text { cup } \\
\text { unknown } \\
\text { plate } \\
\text { plate } \\
\text { plate } \\
\text { unknown } \\
2 \text { cups } \\
2 \text { saucers, } 1 \text { plate } \\
\text { plate } \\
\text { mug }\end{array}$ \\
\hline Decal & floral & pink and green & unknown \\
\hline Molded & floral & - & unknown \\
\hline $\begin{array}{l}\text { Molded and } \\
\text { painted }\end{array}$ & alphabet & red & plate \\
\hline $\begin{array}{l}\text { Painted and } \\
\text { molded }\end{array}$ & lines & blue & unknown \\
\hline
\end{tabular}

inner edge is straight or banded. The segmented feather motifs in the green feather pattern (see Figure $32 e$ ) resemble the hanging fern or tassel edge motif illustrated in Majewski and O'Brien (1987:Figure 3).

Two additional vessels may be edge decorated, although it appears that the molded design occurs at the inner edge of the plate brim. The grape cluster design (Figure 33a) is similar to sprigged wares dating to the second half of the nineteenth century, but the color is characteristic of edged wares and the design is different from the Chelsea Grape or Grandmother pattern (Banks 1983:Figure 28E). The fan design (Figure $33 b$ ) is the same as that illustrated in Banks (1983:Figure 26F). Edge decoration dates from the late eighteenth century to the $1860 \mathrm{~s}$, with production continuing into the 1890s (Majewski and O'Brien 1987:148-151; Miller 1991:6). All of the edged vessels have scalloped rims, indicating that they probably date to the first half of the nineteenth century.

Twenty annular-decorated vessels are represented. With the exception of the banded patterns, other annular decoration types probably date to the first half of the nineteenth century. Ten of these vessels are banded. Some of the banded vessels may represent fragments of other annular decoration types since banding occurs in association with other annular decoration types such as mocha and marbleizing. The only nonearthen blue occurring on these vessels is the medium blue on the bowl (Figure 34a), which may postdate 1840 and was produced into the twentieth century (Miller 1991:7). The dark brown and earthen blue bowl and the dark brown and yellow bowl are carinated vessels.

Six vessels have banding produced by a slip cup and/or impressed patterns produced by pressing 


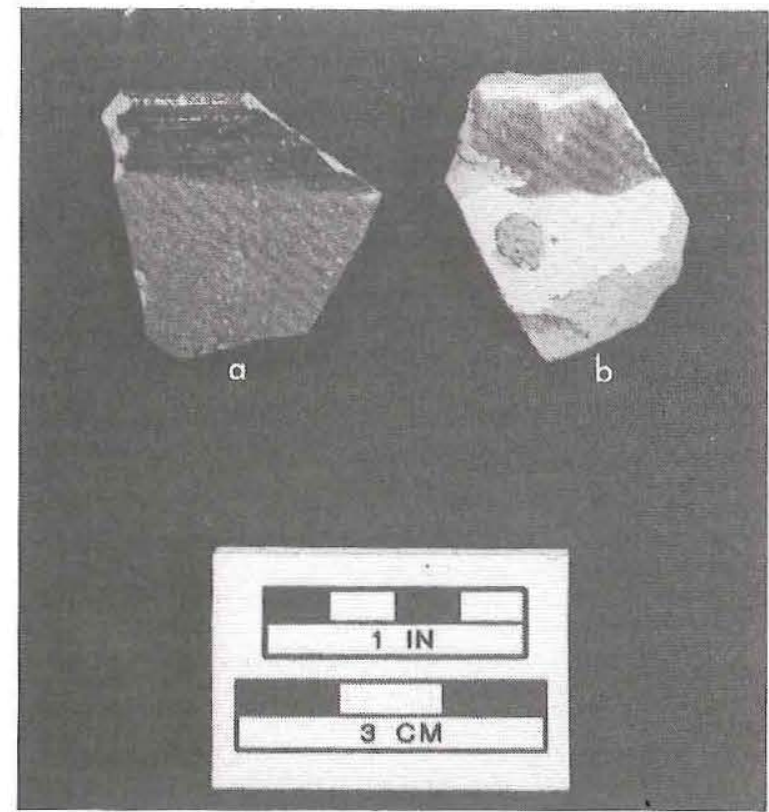

Figure 31. Decorated nonwhitewares, 41HG153. (a) Coarse-paste orange chocolatera rim with brown band, Galera ware; $(b)$ refined redware with wavy orange line and and stilt mark, cf. Guanajuato majolica.

an instrument into the damp slip as the vessel is turned on a potter's wheel (Majewski and O'Brien 1987:163). The variety of these impressed forms is impressive (Figure $34 b-e$ ). Three vessels have marbleized or swirl decoration (Figure $34 f, g$ ). The blue in these patterns is an earthen blue probably representing early nineteenth-century manufacture. A final possibly annular pattern is a cross between dendritic and swirl decoration. This pattern is not a mochalike dendritic pattern and is of unknown date.

Of the twenty-seven underglaze hand-painted vessels represented, nine are a blue thickline floral pattern (Figure $35 a, b$ ). Probable thickline floral patterns in other monochrome or polychrome colors number eight. Thickline and fineline floral patterns are distinguished based on the boldness of the motif (bold on thickline) and the presence of black or brown stems (common on fineline). Thickline patterns are more often monochrome than fineline patterns. Since the sherds are so small and the patterns so fragmentary, it is possible that some sherds have been misclassified. The blue and red cup is dark blue and dark red in color. The green plates are both light green, and one has a medium red rim band (Figure 35c). The red floral saucer has a red rim band, and the green and yellow saucer has a gold-colored (not luster) rim band. Thickline patterns are reported to have peaked in popularity from 1840-1860 (Majewski and O'Brien 1987:159), but the assemblage from Old Velasco indicates the blue thickline patterns date to the 1830s (Earls et al. 1993).

Five fineline floral patterns are identifiable, and none of these represent the classic sprig pattern. Two fineline floral vessels have dark green leaves and black stems. The brown and tan pattern with gold-colored (not luster) rim band consists of brown seed pods with brown tips and possibly brown stems. The blue, olive, yellow, and black saucer (Figure 35d) is classified as fineline because of the black stems linking the floral elements. Fineline patterns date to the mid nineteenth century, approximately 1840 or 1845 to the Civil War (Majewski' and O'Brien 1987:159).

The floral pattern vessel (Figure 35e) dates to the nineteenth century but is too fragmentary for a more-specific date. A bright blue and black pattern occurs on a semivitreous whiteware vessel. This is the only decorated semivitreous vessel in the assemblage. The yellow, blue, green, and black vessel (Figure 35f) has a bold floral design created by the use of black lines on the yellow floral element.

One vessel is sponge stamped. The design is the usual floral in a dark teal green. Spongestamped decoration occurs at sites dating to the mid nineteenth century, from 1845 until the Civil War (Majewski and O'Brien 1987:161-162) or slightly later.

Eighteen vessels are transfer printed. Although some of the patterns are classified as floral, it is possible that they are actually Oriental, Romantic, etc. since many of these patterns incorporated abundant floral elements.

Eight vessels are printed in blue, and one of these is a flow blue plate. Unidentified rim patterns (Figure $36 a, b$ ) have closed designs probably dating to the second quarter of the nineteenth century. The saucer base (Figure 36c) has the well wreath portion of the Spode Woodman pattern believed to have been introduced in 1814 (Coysh and Henrywood 1982:408-409). The Spode Works and its successors have been in operation since the late eighteenth century, and it is unknown if other makers used the same well 


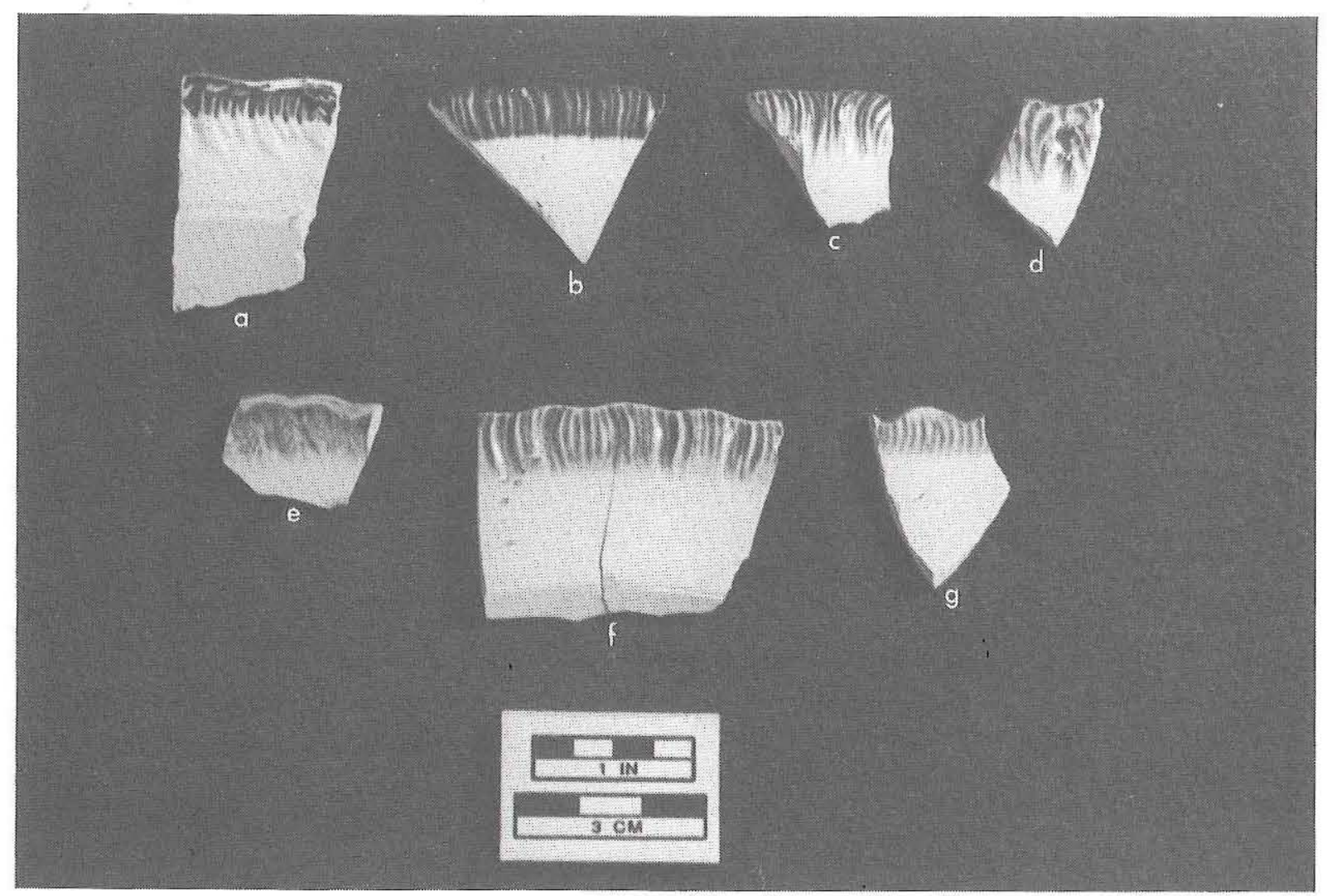

Figure 32. Edge-decorated whitewares, 41HG153. (a) Blue feather and plume plate rim; $(b)$ blue shell plate rim with straight inner edge; $(c-d)$ blue shell plate rims with uneven inner edges; $(e)$ green feather and plume plate rim; $(f-g)$ green shell plate rims with straight painted inner edge.

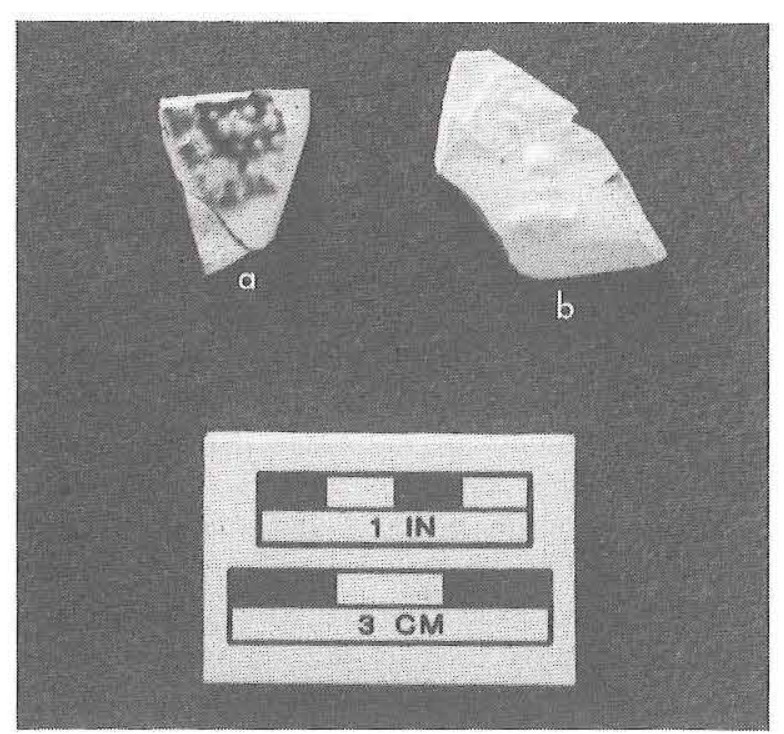

Figure 33. Molded-edge whitewares, 41HG153. (a) Green vessel with molded grape cluster; $(b)$ molded fan plate. wreath design. The blue plate (Figure 36d) with an unidentified well wreath pattern probably dates to the first half of the nineteenth century. The floral pattern vessel (Figure 36e) dates to the nineteenth century but is too fragmentary for a more-specific date. The blue floral plate has a closed brim pattern (Figure $36 f$ ), but too little is present to indicate a date. The plate with the geometric pattern (Figure $36 g$ ) is a relatively open pattern lacking a well wreath design and may be flow blue; this type may date to the mid nineteenth century. A floral transfer vessel has a pattern name fragment with only a floral portion present. The flow blue plate probably dates $1835 / 1840$ 1910 (Williams 1981:ii).

Three vessels are printed in black. One is a Canova plate (Figure 37a). Canova was made by at least four British potters: Thomas Mayer, J. \& M. P. Bell \& Co., David Methven \& Sons, and George Phillips (Coysh and Henrywood 


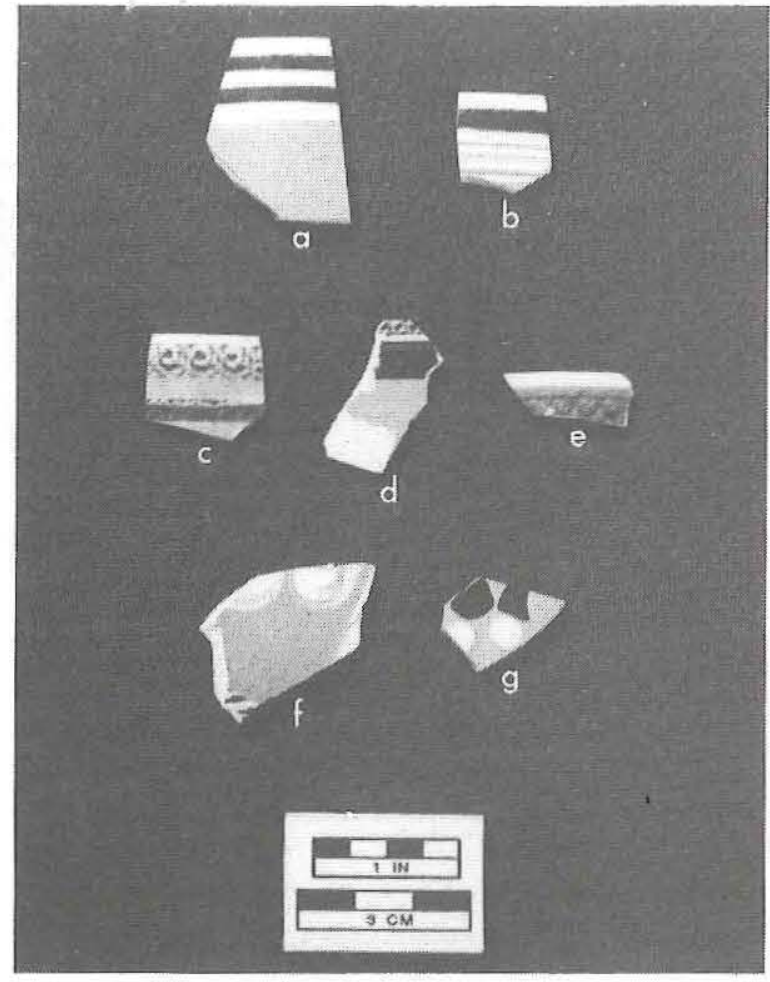

Figure 34. Whitewares with annular decoration, 41HG153. (a) Rim of large bowl with brown bands and bright blue ground; $(b)$ bowl with impressed lines in green below brown band; $(c)$ bowl rim with impressed circles in green, and brown and tan bands; $(d)$ vessel with impressed crosshatching in green, brown band, and olive green ground; (e) bowl rim with impressed hearts in blue; $(f)$ vessel with brown marbleized decoration and swirly white dots on $\tan$ ground; $(g)$ vessel with brown, blue, and white dots on tan ground.

1982:69). Based on work at sites along the lower Brazos River, particularly marked examples from the Brazosport Archaeological Society's Velasco type collection, this pattern probably was made by Thomas Mayer and dates 1826-1838. Mayer exported extensively to the United States (Godden 1964:423).

The other two black transfer-printed vessels are a heavily stippled plate fragment (Figure $37 b$ ) probably dating to the second quarter of the nineteenth century and a possible flow black open floral design probably dating to the mid nineteenth century or later.

Five vessels are printed in red. The patterns are stippled heavily (Figure $37 c-e$ ) and appear to date to the second quarter of the nineteenth century. The plate fragment has a floral fragment of a

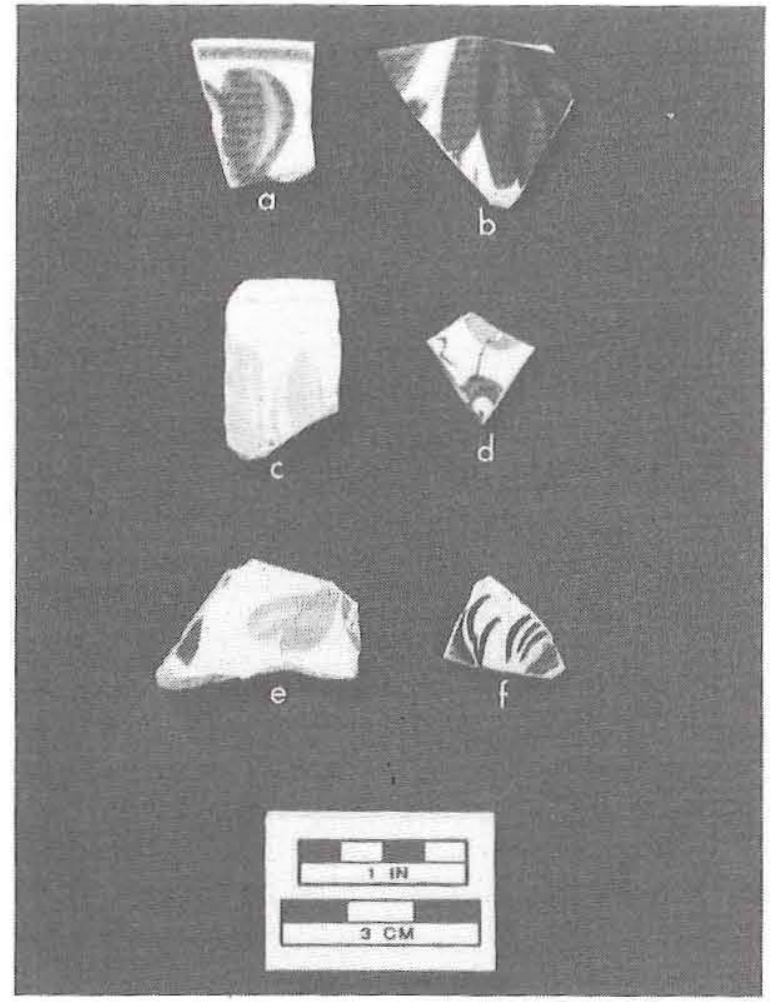

Figure 35. Whitewares with underglaze hand-painted decoration, 41HG153. (a) Blue thickline floral shallow bowl rim; $(b)$ blue thickline floral cup; $(c)$ red and green thickline floral plate rim; (d) blue, olive, yellow, and black fineline floral saucer; $(e)$ blue, olive, and tan floral saucer base; $(f)$ yellow, blue, green, and black floral vessel.

\section{pattern name mark.}

Two vessels are printed in purple. One is a mug (Figure 37f), and the other is a plate with a fragmentary pattern name and maker's mark (Figure 37g). The maker's mark, contained within a banner below the pattern name, is "JACKSON," and the pattern is heavily stippled, typical of the early nineteenth century. The only British potter documented during this early time period as having spelled out the name Jackson is Job \& John Jackson, in business from 1831-1835 (Godden 1964:349).

One floral decal vessel is represented. Eroded decal decoration such as this dates to the first quarter of the twentieth century (Majewski and O'Brien 1987:146-147; Moir 1987a:103-106).

Three vessels with molded decoration are represented. One vessel is molded below the rim in a bold floral design typical of whitewares, particularly ironstones, dating to the second half of 


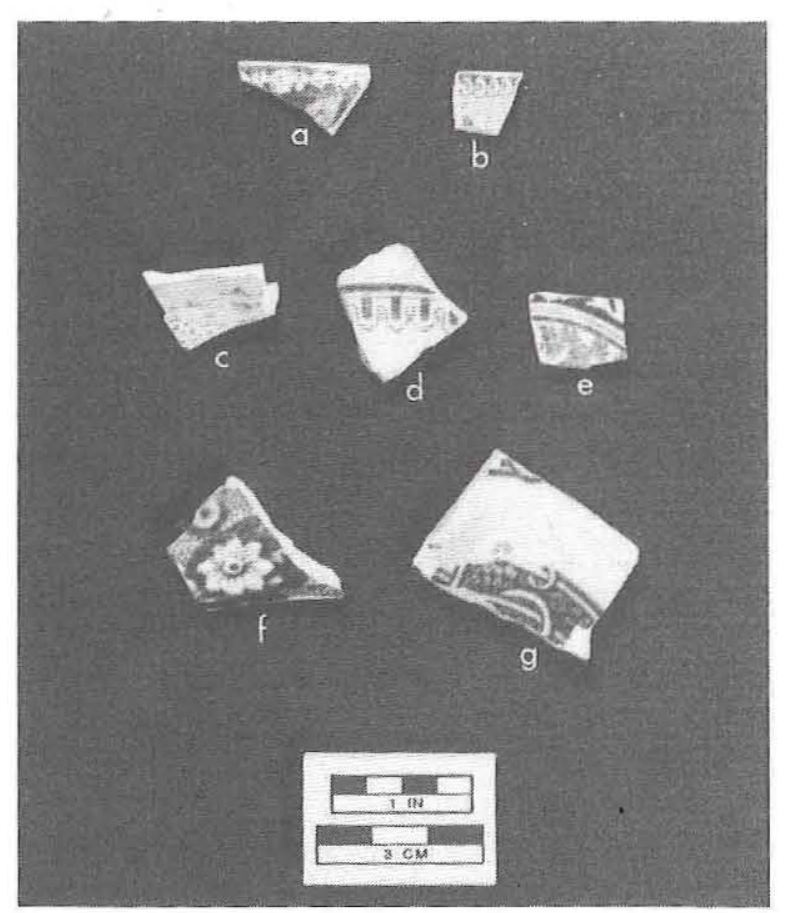

Figure 36. Blue transfer-printed whitewares, 41HG153. (a) Cup rim with deep blue unidentified pattern; $(b)$ saucer rim with blue unidentified pattern; $(c)$ saucer base with blue Woodman pattern; (d) plate brim with blue unidentified pattern; $(e)$ vessel with blue unidentified pattern; $(f)$ plate brim with blue floral pattern; $(g)$ plate base with blue geometric pattern.

the nineteenth century. A full-sized alphabet plate (Figure 38) with a molded $\mathrm{Z}$ and an underglaze hand-painted red rim band is similar to Romantic transfer patterns illustrated in Williams (1978:550, 558, 562). It most resembles the London Dog Seller pattern (Williams 1978:550) in its embossed letter and red rim band. The patterns illustrated in Williams (1978:11) generally date from ca. 1835 to ca. 1855. Another molded and painted vessel consists of fine molded parallel lines, some painted. This pattern appears to be a twentiethcentury type.

The distributions of temporally diagnostic decoration types by unit were examined to determine if any spatiotemporal clusters are identifiable in this plowed field. Edged vessels dating to the first half of the nineteenth century occur in Units 5-11 and 13 in the east-central portion of the site. The stoneware ginger beer/aletype bottle dating from the 1840 s to 1900 occurs in Unit 10 near the center of the site. Annular banded, banded and impressed, and marbleized or

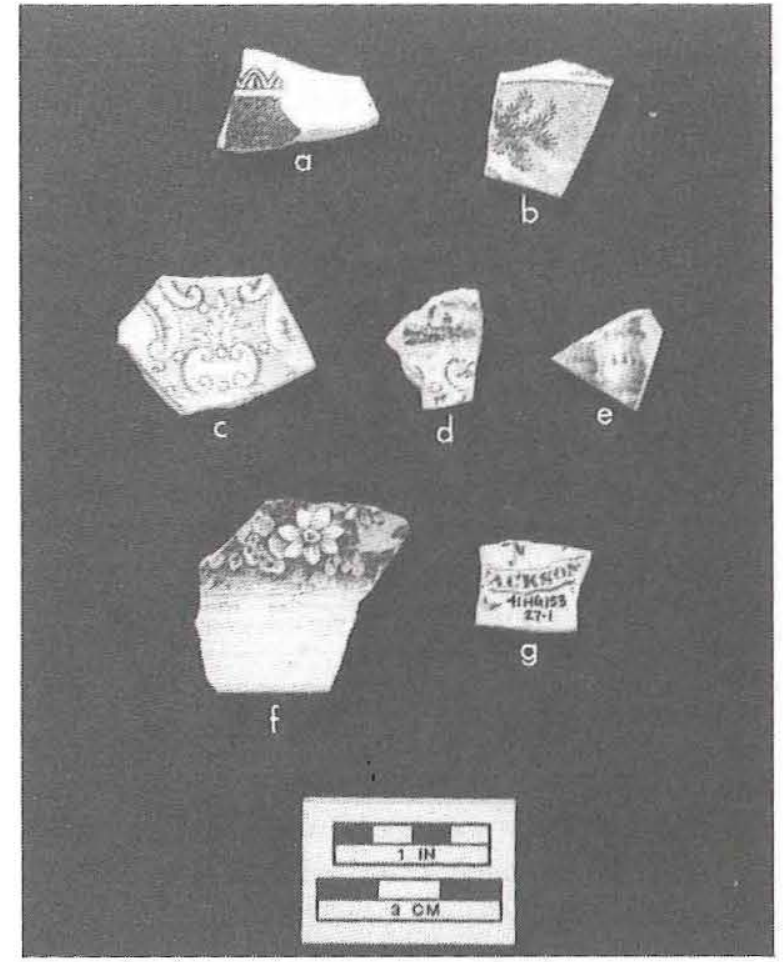

Figure 37. Transfer-printed whitewares, 41HG153. (a) Black Canova plate rim; $(b)$ black plate base, unidentified pattern; $(c-d)$ red saucers, unidentified patterns; $(e)$ red plate base, unidentified pattern; $(f)$ purple mug base, floral pattem; $(g)$ purple plate base with printed Jackson mark.

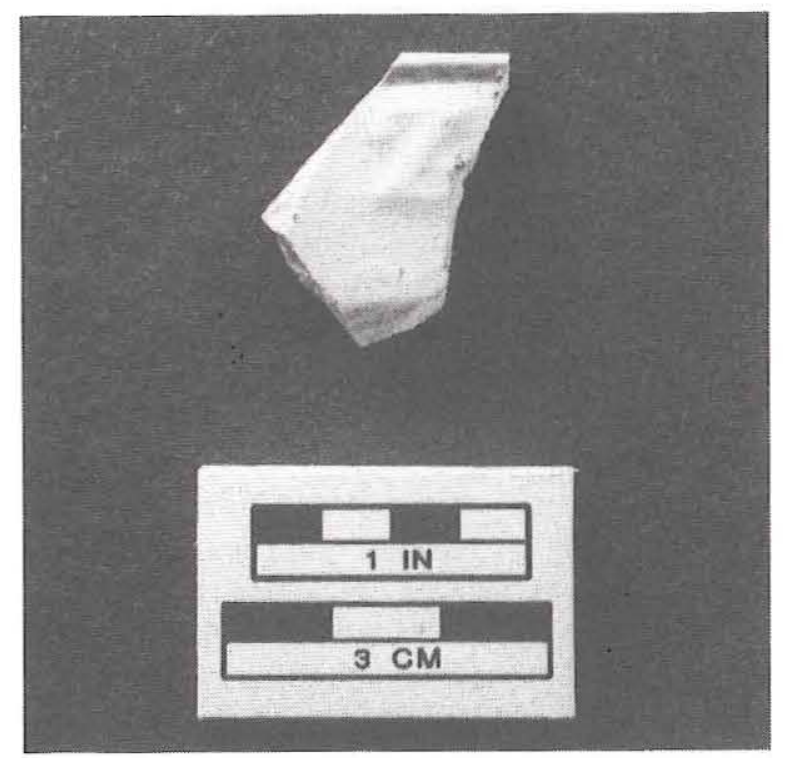

Figure 38. Alphabet plate rim with red rim band and molded Z, 41HG153. 
swirl vessels dating to the first half of the nineteenth century occur in Units 4, 6-11, 13, and 16 in all but the east and west ends of the site. Underglaze hand-painted blue thickline floral vessels dating from the 1830 s to 1860 s occur in Units 9-13 in the center of the site and Unit 19 on the west end. Other thickline and fineline floral patterns probably dating from the $1840 \mathrm{~s}-1860$ s occur in Units 7, 9, 11, and 13-17 in the westcentral portion of the site. The sponge-stamped vessel dating 1845 until 1865 occurs in Unit 20 on the west end of the site. Transfer-printed vessels dating to the second quarter of the nineteenth century occur in Units $8-16,18$, and 20 in the central and western portions of the site. The Canova pattern vessel dating 1826-1838 occurs in Unit 12, and the Jackson vessel dating 1831-1835 occurs in Unit 15 in the west-central portion of the site. A transfer pattern probably dating to the mid nineteenth century occurs in Unit 14 in the center of the site. The alphabet plate occurs in Unit 9 in the center of the site. Flow vessels dating 1835/18401910 occur in Units 9, 14, and 20 in the central and western portions of the site. The floral molded whiteware probably dating to the second half of the nineteenth century occurs in Unit 14 in the center of the site. The floral decal dating to the first quarter of the twentieth century occurs in Unit 15 in the west-center of the site. The twentieth-century painted and molded type occurs in Unit 15 at the west-center of the site. The distribution of decoration types indicates that most temporally diagnostic types occur in the center of the site, but no cluster of pre-Mexican War or midcentury ceramics can be identified.

The lack of meaningful patterns in the horizontal ceramic distributions probably is due in part to recent agricultural disturbances. Evidence of this was found in one crossmend across several units. This refit consists of two green and black hand-painted sherds found in Units 17 and 21, at least $60 \mathrm{~m}$ apart.

The ceramic assemblage from this site represents edged, annular, thickline floral, and transfer-printed vessels, including two marked examples, dating to the first half of the nineteenth century and probably predating the Mexican War. This assemblage is the only one from the project area containing edge-decorated ceramics, and the variety of edged, annular, and transfer-printed patterns dating to the early nineteenth century indicates a relatively intense occupation. The polychrome thickline and fineline floral, spongestamped, and transfer-printed and flow types date to the mid nineteenth century. The number of decoration types postdating the Civil War is limited to a bold molded floral probably dating to the second half of the nineteenth century, a floral decal dating to the first quarter of the twentieth century, and a painted and molded type probably dating to the twentieth century. The ceramic assemblage appears to reflect primary occupation in the second quarter of the nineteenth century, probably prior to the Mexican War, and perhaps continuing as late as the Civil War. The assemblage is remarkably short term and unmixed despite intensive recent agricultural use of the site.

\section{GLASS}

Thirteen fragments of glass were collected from this site (Table 20). None of the glass is fluorescent under shortwave ultraviolet light, indicating lack of lead content.

At least seven vessels are represented, and these include one olive green cylindrical (probably wine or champagne) bottle, one colorless Ball jar, and one solar-purpled small medicine bottle. Present in very fragmentary form are two aqua, one emerald green, and one colorless cylindrical bottles. Noncollected vessels include two brown beer bottles with stippled embossing on the base indicating twentieth-century manufacture. A piece of patinated flat glass measures $2.12 \mathrm{~mm}$ thick; using Moir's (1987b:77-78) formula for window glass, the estimated manufacture date is 1891 .

The olive green bottle probably was manufactured during the first half of the nineteenth century. The Ball jar with script lettering, on the other hand, postdates 1892-1893 (Berge 1980:100). The medicine bottle probably dates to the $1860-1920$ period of popularity, and the solar-purpled color narrows the range to the last $40-45$ years of this period (Fike 1987; Jones and Sullivan 1989:13).

All of the glass, including the temporally diagnostic olive green bottle, Ball jar, and medicine bottle fragments, occurred in the central portion of the site (Units 7-16) containing $86 \%$ of the artifacts observed and collected. The temporally diagnostic bottle glass reflects possible preCivil War occupation as well as late nineteenth/ early twentieth-century disposal. 


\begin{tabular}{|c|c|c|}
\hline \multicolumn{3}{|c|}{$\begin{array}{c}\text { TABLE } 20 \\
\text { COLLECTED GLASS, } 41 \mathrm{HG} 153\end{array}$} \\
\hline $\begin{array}{l}\text { Collection } \\
\text { Unit }\end{array}$ & Color and Type & No. and Description \\
\hline 7 & patinated cylindrical bottle & 1 body sherd \\
\hline 8 & colorless cylindrical bottle & 1 body sherd \\
\hline 9 & olive green cylindrical bottle & 1 body sherd \\
\hline 9 & patinated flat glass & $\begin{array}{l}12.12-\text { mm-thick body } \\
\text { sherd }\end{array}$ \\
\hline 11 & colorless jar & $\begin{array}{l}1 \text { base sherd marked with } \\
\text { "Ball" in embossed script }\end{array}$ \\
\hline 12 & solar-purpled medicine bottle & $\begin{array}{l}17 / 8 \text {-inch wide oval base } \\
\text { sherd marked with "HV" } \\
\text { on heel }\end{array}$ \\
\hline 12 & colorless bottle & 1 base sherd \\
\hline 13 & olive green cylindrical bottle & 1 body sherd \\
\hline 14 & colorless bottle & $\begin{array}{l}1 \text { base sherd with post } \\
\text { base seam and side seam }\end{array}$ \\
\hline 16 & olive green cylindrical bottle & 1 body sherd \\
\hline 16 & aqua cylindrical bottle & 2 body sherds \\
\hline 16 & emerald green cylindrical bottle & 1 body sherd \\
\hline
\end{tabular}

perhaps continuing as late as the Civil War. The glass assemblage indicates pre-Civil War occupation as well as late nineteenth/ early twentieth-century disposal. The artifact assemblages are temporally discrete and notably limited in the occurrence of twentieth-century materials, unlike the long-term, mixed assemblage at $41 \mathrm{HG} 158$.

\section{Discussion and Evaluation}

Archival evidence indicates that site $41 \mathrm{HG} 153$ is the location of the earliest known settlement within'the project area. It is within the 1767 Hinojosa land grant, and in the early 1800 s may have been associated with the Hinojosa, Cavazos, and/or Anaya families. By the mid 1800 s, it clearly was associated with the Anaya and Garza families. Archival and informant data suggest that the site was occupied mainly during the nineteenth century but was abandoned by the early part of the twentieth cen-

\section{BONE}

Eight bone fragments were recovered. A partially burned long bone fragment with a metal knife cut mark was recovered from blading in Unit 9, and two long bone fragments from the same bone were recovered from blading in Unit 10. The medial section of a weathered metatarsal was recovered from posthole Feature 12, and a possible distal epiphyseal portion of a long bone was recovered from posthole Feature 21. The fragments probably are from a large ungulate, probably a cow, based on size, but no attributes definitely diagnostic of cow (versus bison) are present.

\section{SUMMARY}

The ceramic assemblage reflects primary occupation in the second quarter of the nineteenth century, probably predating the Mexican War and tury. Artifactual evidence is consistent with this interpretation because the assemblage is dominated by nineteenth-century materials.

While the archival records suggest that the historical component is significant, the archeological evidence clearly indicates that the site lacks integrity. The only documented features are postholes associated with a twentieth-century wooden fence and a charcoal/ash lens associated with modern vegetation clearing for agricultural purposes. The stratigraphy provides evidence that extensive land leveling resulted in high areas being truncated and low areas being filled in. This, along with a 50-cm-deep plow zone across the site, indicates that there is little chance that any artifacts or features associated with the original nineteenth-century occupation remain intact. The linear distribution of artifacts, in an east-west band along the edge of the terrace, apparently is unrelated to the nineteenth-century historic 
activities. Rather, this distribution reflects the modern agricultural practice of land leveling, and the artifacts are in a secondary context, having been redeposited as part of the fill brought in to raise the edge of the terrace and the roadbed. Thus, the definitive evidence of the site's historic occupation is limited to an artifact assemblage with no meaningful contextual data. Consequently, the historic component of $41 \mathrm{HG} 153$ has little or no research potential, and it is recommended that it be considered ineligible for listing on the National Register of Historic Places.

\section{Prehistoric Component}

Testing of the prehistoric component at site $41 \mathrm{HG} 153$ yielded very poor results as far as the recovery of artifacts and detection of features. The paucity of intact cultural deposits and cultural materials within prehistoric sites in the Lower Rio Grande Valley is well documented (e.g., Bousman et al. 1990; Day et al. 1981; Hall et al. 1987; Kibler 1994; Mallouf et al. 1977). This is due to a number of factors, particularly land modifications and disturbances related to historic agricultural and ranching activities, the prevalence of erosional Holocene environments, and the near absence of lithic raw material sources within the region.

The excavation of the six backhoe trenches and one $1-x-1-m$ test unit failed to produce any prehistoric artifacts or features or to detect any intact cultural deposits. A general reconnaissance of the surface did result in the collection of one small utilized flake fragment. The flake tool is made of a mottled grayish brown chert. Use wear is prevalent on one lateral edge and is characteristic of unidirectional scraping.

Specifics about the prehistoric component at $41 \mathrm{HG} 153$, such as site function and the duration of the occupation(s), are impossible to define at this time. However, some simple generalizations and interpretations, based mainly on circumstantial evidence, can be proposed.

Although the site has been greatly disturbed by historic land modifications and agricultural activities, the paucity of artifacts also may suggest that the prehistoric occupation was short term and the locus of specific activities, such as the procurement and initial processing of food resources by a small hunting party. Mussel shell fragments observed on the surface during the current and Phase I investigations (Kibler and Freeman 1993:38) may be related to activities that took place at the site prehistorically.

Chronologically, the prehistoric occupation can be defined as Late Prehistoric based on the collection of a Starr arrow point base during the survey (Kibler and Freeman 1993:38). In the Lower Rio Grande Valley, this period generally extends from A.D. 1200 to the time of contact with Europeans, which did not occur with any frequency until the early to middle eighteenth century. Based on the geomorphological investigations, the site setting during the Late Prehistoric period may have been an ideal place from which to collect freshwater mussels and other aquatic resources, since the Rio Grande channel was adjacent to the terrace edge just prior to A.D. 1300-1600.

The probability that these concepts can be explored and studied further, however, is meager. Evidence from testing suggests that the cultural deposits are very disturbed due to recent activities, and like many prehistoric sites in the region, site 41 HG153 lacks the potential to answer important regional research issues due to the paucity of artifacts and lack of features. Consequently, it is recommended that the prehistoric component at $41 \mathrm{HG} 153$ be considered ineligible for listing on the National Register of Historic Places.

\section{HG156, BRICK FACTORY}

\section{Site Setting}

Site $41 \mathrm{HG} 156$ is the remains of an historic brick factory located along the south edge of a levee immediately north of an unnamed resaca (see Figure 13). The northern portion of the site is on top of the levee, which is $50-100 \mathrm{~cm}$ higher than the southern half of the site. The site is contained within an isolated $60-x-70-m$ block of uncleared land, most of which is covered by a dense growth of trees, vines, shrubs, and grasses. It is bounded on the north and east by an unimproved farm road and plowed fields, and on the south and west by cleared paths that support a dense grass-cover. The site lies at an elevation of $100 \mathrm{ft}$ above mean sea level.

\section{Previous Investigations}

Site 41HG156 was discovered and documented 
during the 1992 survey of High Probability Area 2. It was described as a brick and clay tile factory consisting of the ruins of an adobe-walled kiln surrounded by mounds and scatters of clay products (Kibler and Freeman 1993:43-45). Other historic artifacts (e.g., a glass container with a 1911-1929 maker's mark) and modern debris (e.g., beer and soda bottles) also were noted, and two bricks (one fragment with a frog and one large adobe brick of the type used in the construction of the kiln) were collected. Because of its good archeological integrity, 41HG156 was considered to have good potential for addressing research questions related to the poorly documented brickmaking industry in the Lower Rio Grande Valley, and it was recommended as potentially eligible for listing on the National Register of Historic Places and for designation as a State Archeological Landmark.

\section{Work Accomplished}

The Phase II investigations at $41 \mathrm{HG} 156$ consisted of detailed field recording of the site along with additional archival and oral history research. Field archeological investigations included mapping of the surface topography and locations of the kiln and other cultural features (Figure 39), detailed recording and photographic documentation of the kiln and other features, and surface collection of selected diagnostic artifacts. To facilitate mapping of the densely vegetated site area, mimimal brush clearing was done and multiple datum points were established and marked with rebar. All elevations are relative to an arbitrary $100.00 \mathrm{~m}$ at the primary datum. Surface collection concentrated on obtaining a representative specimen of each different type of brick found in the site area. A shovel probe also was excavated in an attempt to locate the floor of the kiln.

Fieldwork also included a site visit by architect Robert Steinbomer who served as a consultant to help identify brickmaking features and processes. Subsequent to the field investigations, consultations with two anthropologists, Drs. Scott Cook (University of Connecticut) and Joe Spielberg (Michigan State University), who are researching brickmaking in the Rio Grande Valley, provided additional information regarding brick manufacturing processes and sites in the region.

\section{Site History}

Site $41 \mathrm{HG} 156$ is located on land that was granted as Porción 69 to Juan José Hinojosa by the crown of Spain on October 22, 1767 (Deed Record C:586-587). Hinojosa owned the porción until September 3, 1794, when he conveyed it to José Matias Cavasos [Cavazos] (Deed Record E:560561), a resident of Reynosa. Cavasos died, and the land passed to his son, Lino, who conveyed Porción 69 to Rafael Anaya on April 16, 1823 (Deed Record E:562). Following the death of Rafael Anaya, Porción 69 passed to his heirs, one of whom, Luciano Anaya, passed his interest to a child, Luciana Anaya (Deed Record E:560-562). Another interest passed to Maria Aloquea Anaya de la Garza (wife of Jesus de la Garza), who had inherited from Manuel Anaya (Deed Record A:304-305). The Anaýas and Garzas were living on the porción in 1852 when the grant was confirmed to the heirs and assigns of Juan José Hinojosa in February 1852 (Deed Record C:586587). The Hidalgo County sheriff and tax collector certified that the owners of Porción 69 had presented him tax receipts for the years 1852-1881 (Texas. General Land Office 1882a, 1882b), thereby affirming their legal ownership and clearing the way for the issuing of patents the same year. Other legal records confirmed that the Garzas were early residents of Hidalgo County, two family members having served on boards and commissions since the mid nineteenth century. Tomas Garza, for example, was appointed Road Commissioner on September 2, 1852. Bernardo Cantu and Luis Anaya served on the Petit Jury in the early 1860 s representing the precinct in which El Capote was located (Court Record Book A:2, 63,99 ).

After the Civil War, much of the land in Porciones 69 and 70 began to change hands, with ownership often passing to Anglo-Americans who used their official status as an advantage to acquire lands from the land grant heirs. For example, Edward Dougherty, Martin Norgrave, and Jacob T. George attempted to acquire an interest in Porción 69 from members of the Anaya and Garza families (Deed Record A:304-305). In addition, the county judge, Thaddeus M. Rhodes, was notorious for using sheriff's auctions at this time period to obtain many parcels of land. In 1878, Rhodes bought a 30-acre tract of Porción 69 from Josefa Cavazos 

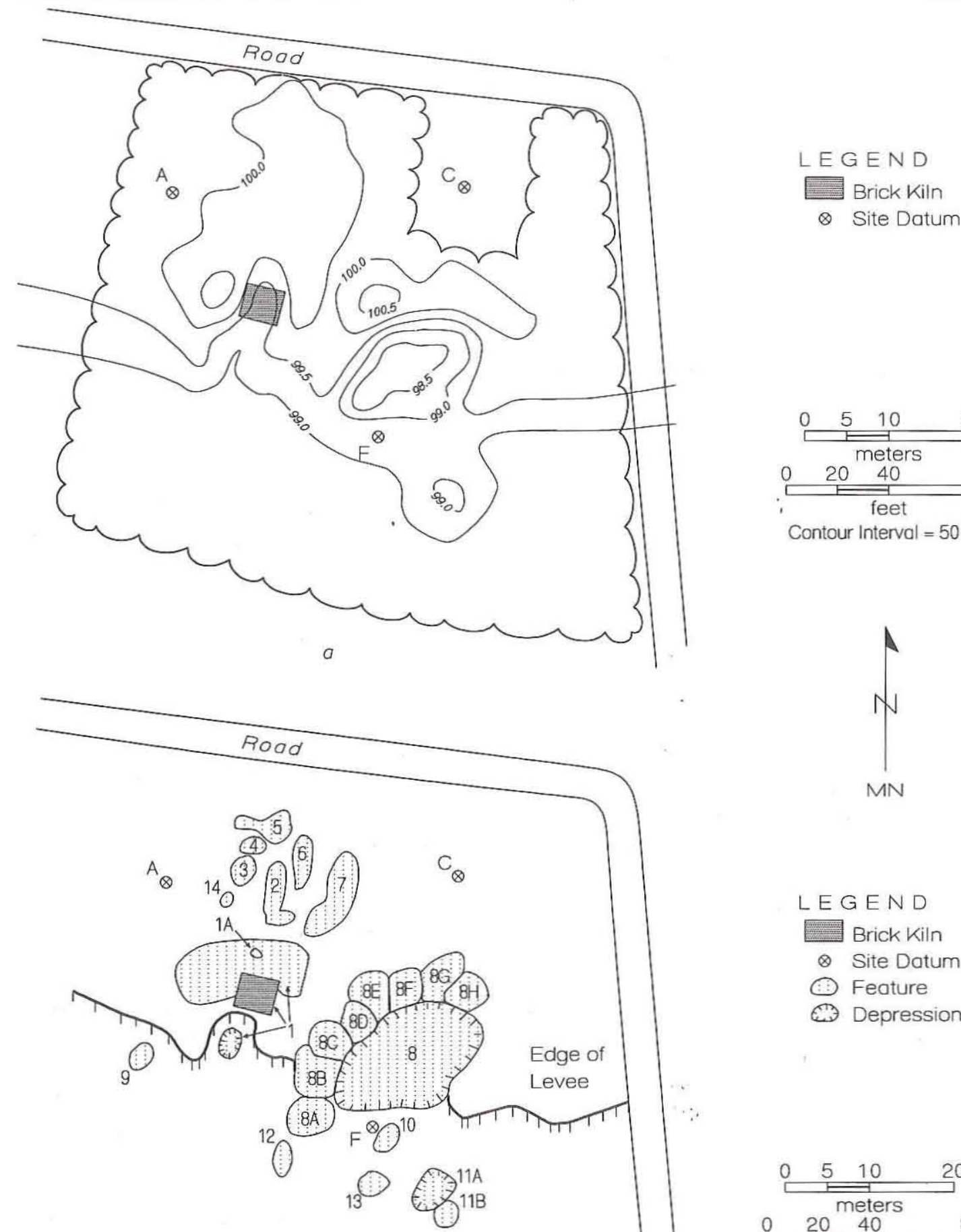

LEGEN D

Brick Kiln

$\otimes$ Site Datum

(D) Feature

त) Depression
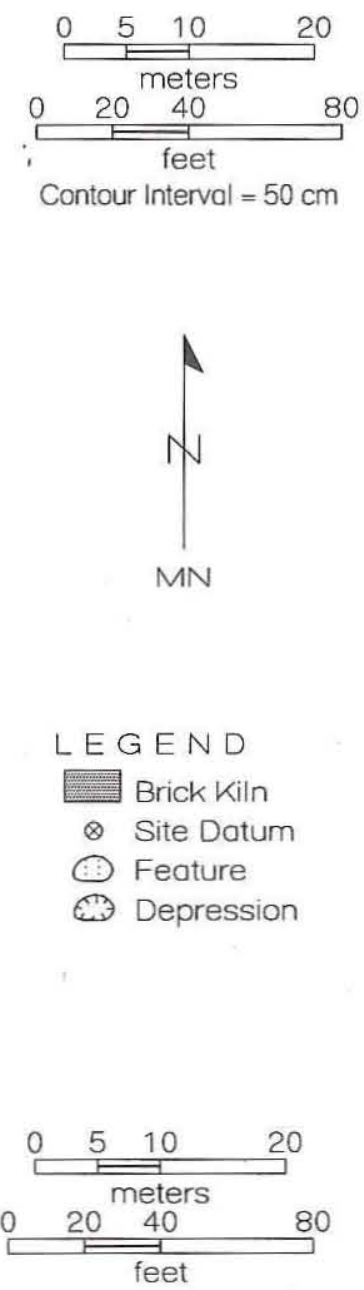

$b$

P\&AI/94/SLH

Figure 39. Site maps of $41 \mathrm{HG} 156$ showing $(a)$ surface topography and kiln and $(b)$ locations of all cultural features. 
and held a sheriff's auction on 668 acres of Concepción Anaya's part of the porción. However, Anaya sold her land to Manuel Cantu (Court Record Book 1:149). Bernardo Cantu had already begun to acquire the interests of his neighbors in Porción 69 years earlier. On January 18, 1867, for example, he purchased half of the interest of Luciano Anaya, son of Rafael Anaya, from Luciano's child and heir, "said right being understood to by [sic] on or about a place called Capoté on said porcion of land ..." (Deed Record E:563). As a result, El Capote community and lands are remarkable for the tenacious hold its original family owners maintained on it, despite the fact that surrounding lands were changing hands regularly.

In 1898-1900, Hidalgo County Sheriff John Closner and his partner, James B. Wells, acquired land within Porciones 69 and 70 (Deed Record I:56-57). At the same time, Closner and Wells acknowledged the title claimed by Guillermo Garza, Alejandro Garza, and Isabel Garza de Guajardo (the heirs of Valentin Garza), stating that the tract was "now, and for many years ... past, actually held, occupied and possessed by the said Guillermo Garza, and others, Heirs, of the said Valentin Garza, deceased" (Deed Record J:111113). The land surrounding 41 HG156 eventually was sold to Eduardo G. Vela, whose heirs still own the property (Vela 1993).

The physical features of 41HG156 and the immediate vicinity include a brick kiln, several houses, and the Military Road. The site is within an area depicted as a large ranch complex on a map surveyed by the International Boundary Commission in 1927-1928 (see Figure 12). Local informants indicate that there were several houses on or near site 41HG156, including those of the grandsons of Guillermo Garza, Sr., which were leveled around 1940. His grandsons, Nestor Garza, Jr., and Roberto Garza, both reportedly had large casas de leña de reboque with thatched roofs. Amado Lozano also had a nearby home made of board and batten or madera parada as well as a small store. And Pedro Guajardo built a boardand-batten home and store around 1923, but it is unclear whether they were located at 41HG156 or elsewhere in El Capote area. He also built a brick factory at $41 \mathrm{HG} 156$ which operated until around 1922. The brick factory (ladrillera) and the land on which it was located belonged to Guajardo, a direct descendant of one of the original families.
Pedro Guajardo, who lived from 1875-1952 and is buried at El Capote (McAllen Genealogical Society 1976), was an uncle of Roberto Garza and Nestor Garza, Jr., recent owners of site 41HG156. The ladrillera had a well and produced bricks primarily for sale along the Military Road (Garza and Garza 1993).

Another informant, Edward C. Vela, stated that his father, Eduardo G. Vela, bought 350 acres at El Capote in the early 1940s, including the area where 41HG156 is located (Vela 1993). Apparently Eduardo hired Mexican braceros (temporary laborers) as field hands, and some of them had made bricks in Mexico. Edward stated that his father built and used the brick kiln at 41HG156 between 1946 and 1948 but that he made the bricks for his own use and never sold any of them. Edward remembered that the kiln was small, perhaps $10 \times 12 \mathrm{ft}$, and that the walls were made of two layers of bricks. Mesquite was used as fuel, but the kiln was only used intermittently and there were never more than five or six men working there. When the kiln was abandoned, Eduardo apparently left a stockpile of bricks at the site, but they subsequently were stolen. Two houses that were built with bricks made at the site still exist, one being in Hidalgo and one in Pharr.

It cannot be stated with absolute certainty that the 1946-1948 Vela kiln is the same structure as Guajardo's pre-1922 kiln, but this is probably the case. The archeological evidence (see Features) suggests that two different types of bricks were made on site and that the 41HG156 kiln was rebuilt at some point in its history. In addition, the different informants clearly note that $41 \mathrm{HG} 156$ is the location of the kiln used by Pedro Guajardo (Garza and Garza 1993) and by Eduardo Vela (Vela 1993).

\section{Features}

Fourteen cultural features were documented at 41HG156. Several of the features are interpreted as integral components of the brick factory, while others are interpreted as secondary trash dumps that postdate the brick factory. Each feature is described individually below, followed by a summary of all of the features.

\section{Feature 1}

Feature 1 is the ruins of an adobe-walled kiln 
structure and the depressions and brick mounds immediately adjacent to it (see Figure 39). The kiln ruins consist of intact portions of three walls enclosing a depression (Figures 40 and 41a). The north and south walls are partially intact and obvious (Figure $41 b, c$ ), while the east and west walls are largely buried by sediment and are more obscure. All four corners were identified, however, and the interior dimensions of the kiln are $4.80 \mathrm{~m}$ east-west by $3.85 \mathrm{~m}$ north-south (or $15 \mathrm{ft}$ 9 inches by $12 \mathrm{ft} 8$ inches).

The kiln appears to have been a semisubterranean structure with the adobe walls built on top of the level levee ground surface and the interior subsequently dug out to form a submerged firing chamber. The north and south walls (see Figure $41 a, b)$ clearly show that the clayey sediment below the base of the adobe walls has been fired. A shovel probe was excavated in the central part of the depression in an attempt to find the floor of the kiln. The $30-x-30-\mathrm{cm}$ shovel probe was excavated to a depth of $20-30 \mathrm{~cm}$ through the loosely consolidated sediment and leaf litter. At that depth, numerous brick fragments and a long section of iron pipe were exposed. In order to find the ends of the pipe, the probe was expanded to a $100-x-30-c m$ rectangle, but its ends were not found and the probe was terminated. The presence of a long segment of pipe led to speculation that this might have been a gas-fired kiln, but this idea is discredited because it conflicts with informant data (see Site History) and because no gas holes were found in the pipe.

The base of the adobe kiln walls is at an elevation of $99.80 \mathrm{~m}$, and the lowest point in the shovel probe was at $98.67 \mathrm{~m}$. Thus, the kiln was excavated down at least $1.13 \mathrm{~m}$ into the levee. The highest point, $100.69 \mathrm{~m}$ along the standing south wall, does not necessarily represent the top of the kiln, but it does indicate that the kiln was at least $2.02 \mathrm{~m}$ high from the floor to the top of the walls. Presumably the kiln walls were taller when it was in use, but an unknown portion has eroded away. There is no evidence for a roof, and it is likely that the kiln did not have one.

Based on the minimum kiln measurements, $4.8 \times 3.85 \times 2.02 \mathrm{~m}$ (or $15.75 \times 12.63 \times 6.63 \mathrm{ft}$ ), its volume is estimated to have been at least $37.3 \mathrm{~m}^{3}$ (or $439.6 \mathrm{yd}^{3}$ ). Although ca. 30,000 standard-sized bricks (e.g., $8.25 \times 3.75 \times 2.5$ inches) could fit into this volume, the kiln's actual firing capacity is estimated to have been ca. 20,000 bricks (allowing for firing chambers and spacing between bricks). This is consistent with an 1839 statement (by John Millington in Foster 1970:70) that similar-sized English kilns, typically $13 \times 10 \times 12 \mathrm{ft}$ (with a volume of $520 \mathrm{yd}^{3}$ ), could fire 20,000 bricks at one time.

The north wall appears to have been constructed entirely of large adobe bricks except for a single row of standard-sized bricks (ca. $9.5 \mathrm{~cm}$ wide and $6 \mathrm{~cm}$ thick) forming part of the wall's base at its east end (see right center of Figure $41 b$ ). The smaller bricks may have been placed there to level a shallow depression before laying down the large adobe bricks.

The larger adobe bricks appear to be fairly uniform in size at ca. $50 \times 22 \times 8 \mathrm{~cm}$ (ca. $20 \times 8.5 \times 3$ inches). The exterior of the north wall is not visible because the mound of brick rubble and sediment along the north side is flush with the top of the wall remnant. Remnants of several layers of clay plastering are preserved on the interior of the north wall, and they show evidence of having been fired (i.e., thermal discoloration). A large animal burrow has undercut the central portion of the north wall and has caused some of the wall's base to collapse. The burrow does, however, provide a good exposure of the wall base and indicates that the bottom layer of adobe bricks was laid in a header course (i.e., the long axis perpendicular to the wall) so that the wall base was ca. $50 \mathrm{~cm}$ thick.

The eastern two-thirds of the south wall is intact and partially freestanding (see Figure 41c), but the western one-third has collapsed. The original wall appears to be composed of large adobe bricks of the same size as those in the north wall but was laid in a stretcher course (i.e. the long axis parallel with the wall). The thickness of the base of the south wall cannot be confirmed without excavation, but it may be $22 \mathrm{~cm}$ thick and consist of a single row of bricks, or it may be composed of two rows of bricks and be ca. $50 \mathrm{~cm}$ thick. The clay substrate, which has eroded and undercuts the base of the wall slightly, exhibits evidence of having been fired (i.e., thermal discoloration).

The upper and lower portions of the south wall are quite different, and three lines of evidence indicate that the upper half represents a rebuilt section of the wall (see Figure 41c). Differential preservation of the interior plaster is the first clue. 


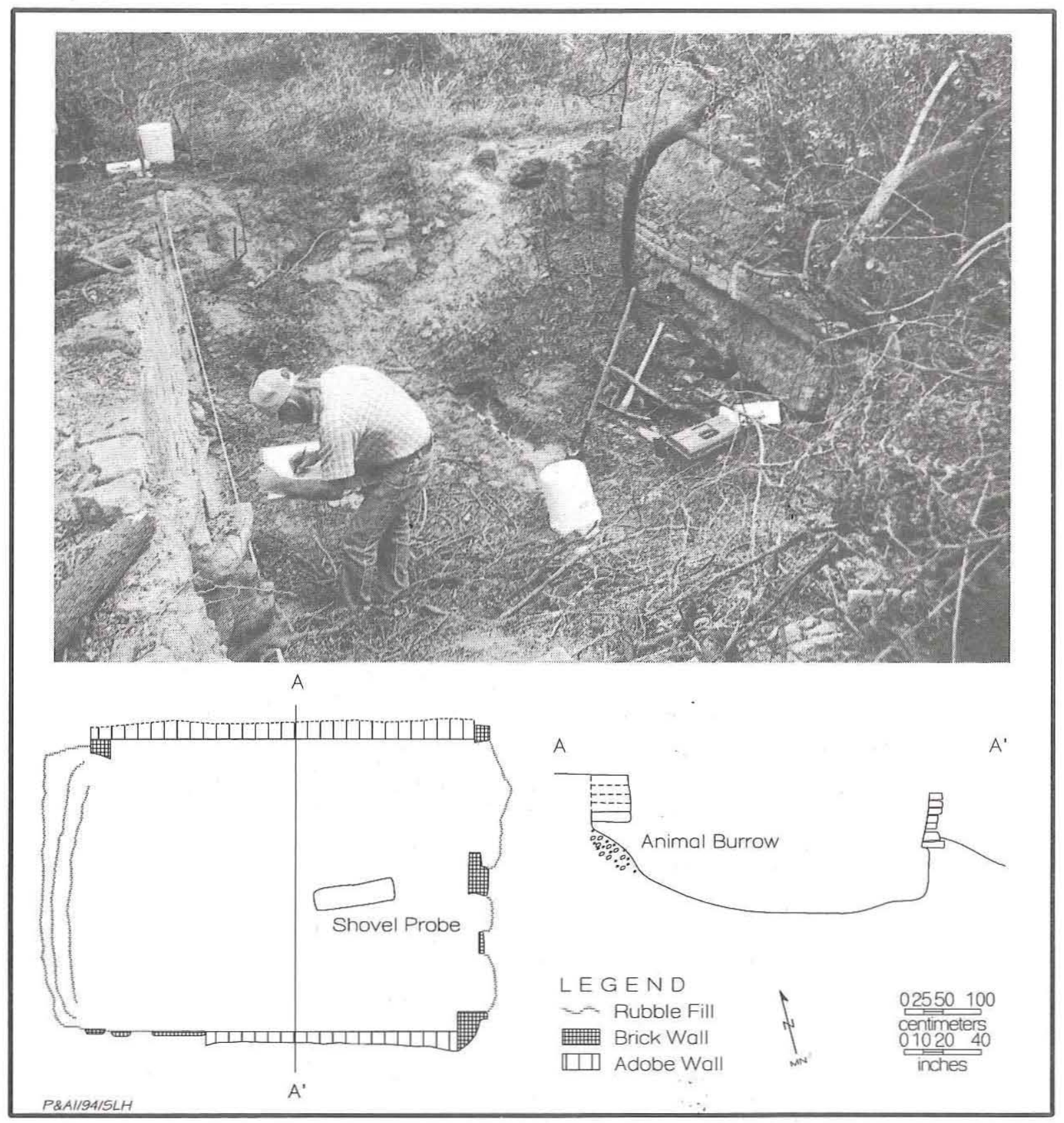

Figure 40. Photograph, plan, and profile of Feature 1, 41HG156. Photograph is a wide-angle overview by Robert Steinbomer looking east. Note the test trench in the center of the kiln.

The lower original section of the wall retains almost no interior plaster, while multiple layers of fired plaster on the upper wall are well preserved and largely intact over most of the wall (except for the westernmost section where the plaster has fallen off to expose the bricks). Second, a thick band of clay mortar marks the abrupt change between the original and the newer wall sections.
Because the mortar band dips significantly from east to west and crosscuts many of the lower bricks, it appears that the original wall was partially collapsed and eroded at the time the later wall was constructed. And finally, the third line of evidence is a distinctive change in wall construction, and the orientation of the adobe bricks in the upper wall is different from that of the original 

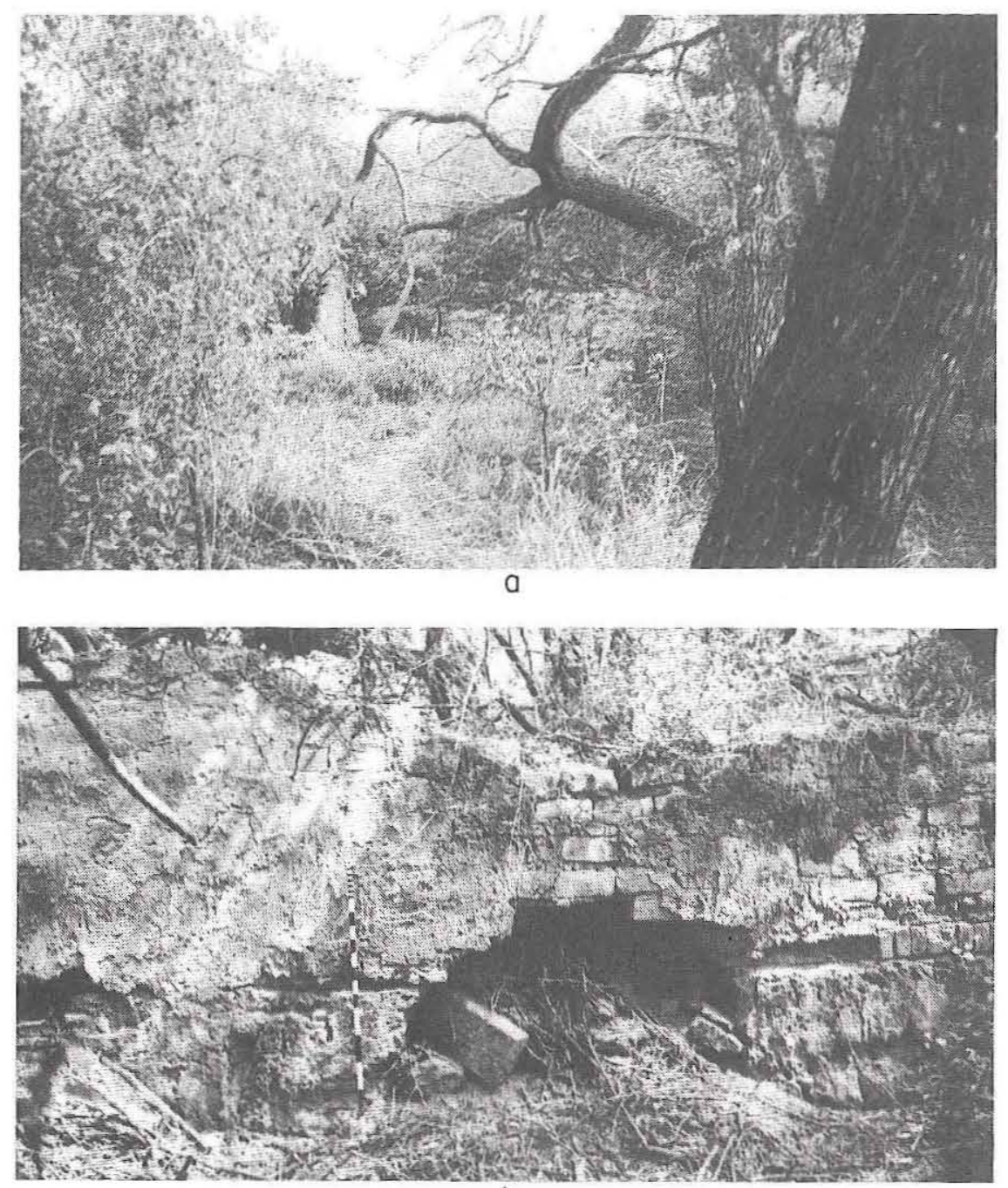

b

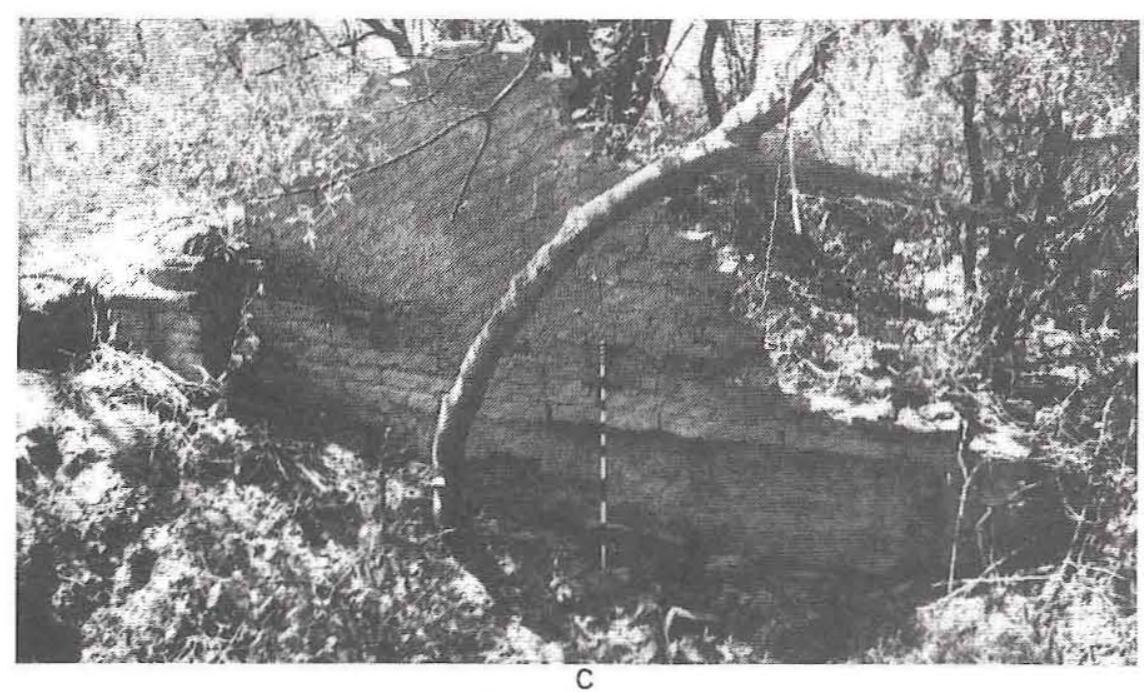

Figure 41. The kiln at 41HG156. (a) Overview looking west showing standing south wall; $(b)$ interior view of north wall showing animal burrow damage; $(c)$ interior view of south wall, with the southeast corner of the kiln on the left. Note evidence of wall rebuilding. 
wall. While the original wall bricks were laid in a stretcher course, the upper wall bricks were laid in a header course (i.e., perpendicular to the wall). Thus, from the inside, the 50-cm-long lower wall bricks are viewed lengthwise, while the $22-\mathrm{cm}-$ wide upper wall bricks are viewed end on.

Most of the newer section is freestanding, but the interior and exterior surfaces are differentially weathered. While the interior surface is relatively intact, the exterior surface is severely weathered and a considerable amount of it has eroded away completely. Parts of the exposed south wall are only $10-15 \mathrm{~cm}$ thick, and no sections are over $30 \mathrm{~cm}$ thick. The better preservation of the interior wall could be due to the presence of the clay plaster, but it most likely is due to the fact that the wall was fired from the interior. Apparently, the unfired adobe on the exterior surface eroded quite easily, up to a point where thermal.alteration changed the consistency of the bricks and made them more durable.

It is unclear whether the reconstructed section of the south wall utilized the same-size adobe bricks as were used in the original south and north walls, but the later bricks are certainly more variable in thickness (i.e., they range from 7.5$10.0 \mathrm{~cm}$ thick). The rebuilt section probably was composed of large adobe bricks laid in a header course so that the wall was $50 \mathrm{~cm}$ thick. If this is the case, then as much as $50 \%-80 \%$ of the wall's exterior surface has eroded away. It is possible that the reconstructed south wall was built using smaller adobe bricks that were $22 \mathrm{~cm}$ wide but less than $50 \mathrm{~cm}$ long. This seems less likely, however, since the newer adobe bricks are not square (i.e., one collected fragmentary specimen is $28 \mathrm{~cm}$ long; see brick Type 3 in Artifacts), and they would have been odd sized (i.e., $22 \mathrm{~cm}$ wide with the length greater than $28 \mathrm{~cm}$ but less that $50 \mathrm{~cm}$ ). Also, thinner kiln walls would not have been advantageous in terms of retaining heat.

The western one-third of the south wall is mostly collapsed and buried by sediment, but careful inspection revealed a difference in wall construction. A few small bricks are exposed in situ along this segment, and they appear to be standard-sized (ca. $8.25 \times 3.75 \times 2.5$ inches) fired bricks. This construction is similar to that observed on the east wall, and as discussed below, it is possible that this portion of the south wall served as an entrance to the kiln.
The west wall of the kiln has collapsed inward and is buried by sediment, but its location can be discerned from remnants of both of its corners. The brick rubble and sediment mound immediately to the west originally butted up against the west wall, but since its collapse, the mound has begun to erode into the kiln depression.

Although the east wall appeared at first glance to be very incomplete, a close examination revealed that there are prepared perpendicular faces that indicate there had been openings along this wall (see photograph in Figure 40). Although the exposed portion of the east wall at the northeast corner is fragmentary, the east wall extends only $25 \mathrm{~cm}$ north from the southeast corner before it terminates with a smooth brick face where an opening had been (see left side of Figure 41c). The wall remnant in the central portion of the east wall also has smooth north and south faces and appears to be a column rather than a remnant wall segment. There is little doubt that there were once at least two (possibly more) openings along the east wall. Since there would have been at least one opening on either side of the central column, it is reasonable to assume that these were arched doorways or eyelets into the firing chamber. Notably, the bricks used to construct the east wall are smaller and more variable in size than those used in the north and south walls.

Immediately south of the kiln is a small circular depression, roughly $5 \mathrm{~m}$ in diameter and $1 \mathrm{~m}$ deep (see Figure 39). It is not clear what this depression represents or exactly how it relates to the kiln. It is likely that this depression might be related to a southern entrance to the kiln. There could have been an entrance along the west end of the south wall, and the similarity in construction between this section of the south wall and the east wall supports this idea. It is unlikely that the kiln had openings "only on one side since most kilns apparently had openings on two sides (usually opposite sides) to provide for adequate fueling and air flow during firing (Robert Steinbomer, personal communication 1993). While openings on two adjoining sides of a kiln might be unusual, there is no particular reason why it would not have functioned well. The presence of a kiln entrance on the south side, however, cannot be confirmed without excavating the kiln.

Immediately north and west of the kiln is a large continuous mound that rises approximately 
$1 \mathrm{~m}$ above the terrace and blends in with the kiln walls (see Figure 39). Without excavation, one can only speculate as to the composition of the mound, but the uppermost portion consists mainly of brick rubble. All of the mound's surface is covered with brick fragments, and an animal burrow ca. $3 \mathrm{~m}$ west of the kiln exposes at least $50 \mathrm{~cm}$ of jumbled brick rubble. All of the brick fragments noted in the Feature 1 mound are Type 1 bricks, but most of them are overfired and severely distorted, perhaps indicating that they represent discarded waste "platting" bricks that were used to cover over and seal the kiln during the final stage of firing (Foster 1970:6; Vogt 1904:177).

Four meters north of the northwest corner of the kiln, a small patterned cluster of bricks was observed on top of the Feature 1 mound. Upon brushing away the leaf litter covering the cluster, a single layer of 12 complete Type 1 bricks in two neatly arranged rows was encountered. This cluster, designated as Feature $1 \mathrm{~A}$, is interpreted as an intact remnant (i.e., part of the bottom layer) of a small stack of fired bricks.

\section{Feature 2}

Feature 2, located $8 \mathrm{~m}$ north of the kiln (see Figure 39 ) is an L-shaped pile of Type 1 brick fragments (Figure 42). The low-lying mound rises only $30-40 \mathrm{~cm}$ above the ground surface. It is $1.0-1.5 \mathrm{~m}$ wide and extends approximately $6 \mathrm{~m}$ north-south with a short 3-m-long eastward extension off its south end. It is interpreted as a waster pile of poorly fired bricks.

\section{Feature 3}

Feature 3 is a low circular mound of Type 1 brick fragments located $10 \mathrm{~m}$ north of the kiln (see Figure 39 ). It is $2 \mathrm{~m}$ in diameter and rises only $20 \mathrm{~cm}$ above the ground surface. Its north edge blends in with Feature 4. Feature 3 is interpreted as a waster pile of poorly fired bricks.

\section{Feature 4}

Feature 4 is a low circular mound of Type 1 brick fragments located $13 \mathrm{~m}$ north of the kiln (see Figure 39). It is $2.5 \mathrm{~m}$ in diameter and rises less than $25 \mathrm{~cm}$ above the ground surface. It is interpreted as a waster pile of poorly fired bricks.

\section{Feature 5}

Feature 5 is a large scatter of Type 1 brick fragments and a few complete bricks located $15 \mathrm{~m}$ north of the kiln (see Figure 39). It covers an area $7.5 \mathrm{~m}$ east-west by $3 \mathrm{~m}$ north-south and generally rises less than $15 \mathrm{~cm}$ above the ground surface. It is interpreted as a waster pile of poorly fired bricks.

\section{Feature 6}

Feature 6 is an elongated scatter of Type 1 bricks and brick fragments located $11 \mathrm{~m}$ north of the kiln (see Figure 39). The 1.5-m-wide scatter extends north-south for $8 \mathrm{~m}$ and rises less than $15 \mathrm{~cm}$ above the ground surface. This feature may be a waster pile, but it contains a greater quantity of complete bricks (i.e., ca. 20) than any of the other waster piles. It appears to represent a 
waster pile of poorly fired bricks, but the usable bricks suggest that there once may have been a stack of complete bricks in this vicinity.

\section{Feature 7}

Feature 7 is an arc-shaped pile composed almost exclusively of Type 2 brick fragments (although a few complete Type 2 bricks are mixed in and a few Type 1 bricks are scattered around it) located $7 \mathrm{~m}$ northeast of the kiln (see Figure 39). The northern end of the mound is very high, ca. $50-60 \mathrm{~cm}$ above the ground level, and is ca. $3 \mathrm{~m}$ wide. The mound tapers to $1.5 \mathrm{~m}$ wide at the southern end where it rises only $20-30 \mathrm{~cm}$ above the ground surface. Although it could represent a dump pile, Feature 7 is interpreted as a waster pile because of the fragmentary nature of the bricks and the absence of mortar on bricks in the main pile. A few Type 2 bricks around Feature 7 appeared to have mud mortar attached, but their occurrence may be fortuitous as is likely the case with the scattered Type 1 bricks.

\section{Feature 8}

Feature 8 is a large depression partially surrounded by mounds of debris located along the edge of the levee ca. $10 \mathrm{~m}$ southeast of the kiln (see Figure 39). The depression is approximately $18 \mathrm{~m}$ east-west by $9-10 \mathrm{~m}$ north-south and appears to be $1.5-2.0 \mathrm{~m}$ deep relative to the ground surface. It is interpreted as a clay borrow pit that provided material for manufacturing bricks, and its yield is conservatively estimated to have been $146-216 \mathrm{~m}^{3}\left(191-283 \mathrm{yd}^{3}\right)$ of sediment. To allow for the fact that the borrow pit is an irregular depression, volume was estimated as $60 \%$ of a rectangular area ranging in size from $18 \times 9 \times 1.5 \mathrm{~m}$ to $18 \times 10 \times 2 \mathrm{~m}$, bearing in mind that the pit is partially filled with debris.

Assuming that all of the sediment extracted from the borrow pit was usable for making bricks, the estimated $146-216 \mathrm{~m}^{3}$ of sediment could have produced ca. $80,663-119,337$ bricks. This estimate is based on a figure of $1.81 \mathrm{~m}^{3}$ per 1,000 bricks, which is derived from the fact that a 4-x-16-x-1-ft "spit" (a standard-sized pit from which brick clay was excavated) yielded enough material for 1,000 standard-sized bricks (Foster 1970:1, 63). If, as previously estimated (see
Feature 1), the kiln could fire ca. 20,000 bricks at one time, then the Feature 8 borrow pit could have produced four to six kiln loads of bricks.

There are eight mounds of brick rubble located along the west and north edges of the depression. These debris mounds, designated as Features 8A$8 \mathrm{H}$, consist mainly of bricks and mortar and are interpreted as dumps (Table 21). Many of these features extend down into the depression, and they represent dumping episodes that obviously postdate the depression. There is a superficial scatter of other trash (e.g., modern glass bottles, aluminum beer cans, and plastic soda bottles) concentrated in and around Feature 8, but it does not appear to be associated with the dumps since the individual dump features are composed exclusively of structural debris.

The dump features appear to be clustered on the west and north side's of the Feature 8 depression. Notably, a clearing in the trees on the southwest and north sides would have allowed for vehicle access from these directions. Conversely, the east and west sides probably are devoid of materials because dense vegetation did not allow easy access for dumping. Other dump features are located in the level area south of Feature 8 (see Features 10-13).

Although Features $8 \mathrm{~A}-8 \mathrm{H}$ appear to represent distinct dump episodes, many of them contain similar materials and could represent contemporaneous dumps. For example, Features $8 \mathrm{~A}-8 \mathrm{E}$ are all composed of the same basic materials (i.e., machinemade Types 4 and 5 bricks, concrete, and mortar) and may have been derived from the same source. Features $8 \mathrm{~F}-8 \mathrm{H}$, on the other hand, are quite different from Features $8 \mathrm{~A}-8 \mathrm{E}$ and contain a much wider variety of materials. Features $8 \mathrm{G}$ and $8 \mathrm{H}$, in particular, are exceptionally large debris piles, and they are unusual for the number of different types of bricks that they contain and because most of the bricks are of Mexican manufacture.

\section{Feature 9}

Feature 9 is a small cluster of Type 1 bricks and brick fragments, most of which have concrete mortar attached. The 2-m-diameter, 20-cm-high cluster also contains a section of a brick wall composed of five bricks still held together by mortar. In addition to the Type 1 bricks, one Type 
TABLE 21

SUMMARY OF DUMP FEATURES 8A-8H AT 41HG156

\begin{tabular}{|c|c|c|}
\hline Feature No. & Size* & Contents \\
\hline $8 \mathrm{~A}^{* *}$ & $\begin{array}{l}3 \mathrm{~m} \text { diameter } \\
40 \mathrm{~cm} \text { high }\end{array}$ & $\begin{array}{l}\text { Types } 4 \text { and } 5 \text { brick fragments (many with concrete mortar attached) and large } \\
\text { concrete fragments. }\end{array}$ \\
\hline $8 \mathrm{~B}^{* *}$ & $\begin{array}{l}4 \times 2 \mathrm{~m} \\
80 \mathrm{~cm} \text { high }\end{array}$ & $\begin{array}{l}\text { Types } 4 \text { and } 5 \text { brick fragments (some with concrete mortar attached). Also modern } \\
\text { glass beer and plastic soda bottles and aluminum cans appear to be concentrated } \\
\text { around this feature. }\end{array}$ \\
\hline $8 \mathrm{C}$ & $\begin{array}{l}3 \times 2 \mathrm{~m} \\
50 \mathrm{~cm} \text { high }\end{array}$ & Types 4 and 5 brick fragments. \\
\hline $8 D^{* *}$ & $\begin{array}{l}2 \mathrm{~m} \text { diameter } \\
65-75 \mathrm{~cm} \text { high }\end{array}$ & $\begin{array}{l}\text { Mainly Type } 5 \text { brick fragments (with yellow and white glazes) but some Type } 4 \\
\text { bricks and concrete mortar (loose and attached to bricks). }\end{array}$ \\
\hline $8 \mathrm{E}$ & $\begin{array}{l}3 \times 2 \mathrm{~m} \text { high } \\
1 \mathrm{~m} \text { high }\end{array}$ & $\begin{array}{l}\text { Mainly Type } 5 \text { brick fragments (with yellow glaze) and some Type 4; also large } \\
\text { concrete fragments and concrete mortar (attached to bricks); long strips of corrugated } \\
\text { black rubber also present. }\end{array}$ \\
\hline $8 \mathrm{~F} * *$ & $\begin{array}{l}3 \times 3 \mathrm{~m} \\
1 \mathrm{~m} \text { high }\end{array}$ & $\begin{array}{l}\text { Mainly large concrete fragments (up to } 50 \mathrm{~cm} \text { ) with some Types } 6 \text { and } 7 \text { brick } \\
\text { fragments. Also observed was a window glass fragment, an undecorated whiteware } \\
\text { bowl fragment, and an octagonal faceted colorless glass (ketchup type) bottle with } \\
\text { threaded lip and maker's mark on its base. Mark is an "O" inside a square and is } \\
\text { identified as that used by the Owens Bottle Co. of Toledo, Ohio, from 1911-1929 } \\
\text { (Toulouse 1971:393). Note that the same mark was observed on another bottle } \\
\text { collected during the } 1992 \text { survey (Kibler and Freeman 1993:44). }\end{array}$ \\
\hline $8 \mathrm{G}$ & $\begin{array}{l}6 \times 3.5 \mathrm{~m} \\
1.2 \mathrm{~m} \mathrm{high}\end{array}$ & $\begin{array}{l}\text { Composed almost entirely of brick fragments: Types } 4 \text { and } 5 \text { in one cluster; Types } 6 \\
\text { and } 7 \text { in a second cluster; and Types } 6 \text { and } 8-12 \text { (many with clay mortar attached) in } \\
\text { a third cluster. Also some large concrete fragments in third cluster. A brown glass, } \\
4 / 5 \text {-quart round bottle (liquor type) also was noted. It has shoulder markings } \\
\text { "FEDERAL LAW FORBIDS SALE OR REUSE OF THIS BOTTLE," a rose inside } \\
\text { an oval, and a maker's mark on its base. Mark is an "I" inside a diamond/circle and } \\
\text { is identified as that used by the Owens Illinois Glass Company of Toledo, Ohio, } \\
\text { from 1929-1954 (Toulouse 1971:403). }\end{array}$ \\
\hline $8 \mathrm{H}^{* *}$ & $\begin{array}{l}3.5 \mathrm{~m} \text { diameter } \\
1.2 \mathrm{~m} \text { high }\end{array}$ & $\begin{array}{l}\text { Many different kinds of bricks (i.e., Types } 6,8 \text {, and } 10-24 \text { ), the majority of which } \\
\text { are of Mexican manufacture. Most are fragments, but some are complete. Some have } \\
\text { clay mortar attached. }\end{array}$ \\
\hline
\end{tabular}

24 brick was noted along with a few fragments of concrete. Feature 9 is located $7 \mathrm{~m}$ southwest of the kiln (see Figure 39) and is interpreted as a dump of structural debris.

\section{Feature 10}

Feature 10 is a $3-\mathrm{m}$-diameter scatter of Mexican-made brick fragments (Types 23, 25, 26, and 27) and concrete mortar located $20 \mathrm{~m}$ southeast of the kiln (see Figure 39). It is a very low (less than $20 \mathrm{~cm}$ high), unobtrusive mound of debris that is interpreted as a dump. A considerable amount of modern trash (e.g., soda bottle fragments and tin cans) scattered around the area does not appear to be directly associated with the dump.

\section{Feature 11}

Feature 11 is a small depression and a debris 
pile located $25 \mathrm{~m}$ southeast of the kiln (see Figure 39). The 3.0-x-2.5-m, 1-m-deep depression may have been a small borrow pit associated with the brick factory. Conservative estimates (based on its minimum size measurements) indicate that the small pit would have yielded only about $7.5-9 \mathrm{~m}^{3}$ of sediment. It could have provided clay for making bricks, but its small size suggests that this is unlikely. Alternatively, since it is directly south of the large borrow pit (Feature 8) and is below the levee, it may have been a source of sand used to lubricate the brick molds. This hypothesis, however, cannot be proven.

The debris pile, designated as Feature 11A, is along the east edge of and spills down into the depression. It covers a $3-x-2-\mathrm{m}$ area, is $40 \mathrm{~cm}$ high, and consists of flat slabs of plastered concrete and some bricks, most of which are complete (Types 2 and 6). It is interpreted as a dump, and it obviously postdates the depression.

\section{Feature 12}

Feature 12 is an elongated (1.5-m-wide by 3 -m-long), low (20-cm-high) mound of several different types of complete bricks and brick fragments. Most are Type 32, but Types 6, 28, 29, and 30 also are present. About half of the specimens are complete, and many have concrete mortar, clay mortar, or lime plaster adhering to them. This feature is located $15 \mathrm{~m}$ south-southeast of the kiln (see Figure 39) and is interpreted as a dump. Modern trash in the area (i.e., tinfoil, styrofoam containers, and plastic picnic utensils) is not directly associated.

\section{Feature 13}

Feature 13 is a large scatter of brick fragments located $23 \mathrm{~m}$ southeast of the kiln (see Figure 39). It covers a $5-x-3-m$ area, is less than $20 \mathrm{~cm}$ high, and consists mainly of brick Types 2 and 6, but a few Type 24 and 32 specimens were present. A single Type 1 brick with mortar attached and a single Type 31 brick also were observed. This feature is interpreted as a dump.

\section{Feature 14}

Feature 14 , located $10 \mathrm{~m}$ northwest of the kiln (see Figure 39), consists of a hackberry tree root that exhibits an unusual growth pattern, apparently having been modified by the presence of brick stacks that are now gone (Figure 43). A small hackberry tree $(20-25-\mathrm{cm}$ base diameter), estimated to be 10-20 years old, grew up around a Type 1 brick that is now embedded in its trunk just above ground level. About $1 \mathrm{~m}$ to the north, a segment of the tree's root is exposed on the ground surface. It has grown in an unusual pattern and has two distinctive, unnatural right-angle bends. The east-west root segment connecting the right angles is flattened as a result of its growth having been restricted between two stacks of bricks. The north and south edges of this root exhibit distinct impressions of the flat brick surfaces, and it even has a slight northward bend where the brick stacks were slightly offset.

Feature 14 provides unmistakable evidence that at least two stacks of bricks were once present at this location. Based on this evidence, several inferences can be made regarding the site. Since the tree is only $10-20$ years old and these two brick stacks must have been present during most of the tree's life, it is reasonable to assume that these stacks were removed rather recently, perhaps within the last 5 years. The presence of brick stacks suggests that some usable bricks were left behind when the kiln was abandoned, and they may have been salvaged by people who found some need for the bricks. Abandoned kiln sites are certainly a likely source of usable bricks, and the brick features (i.e., a wishing well and a barbecue pit with a chimney) at the nearby Vela family picnic area (41HG154, see Kibler and Freeman 1993:40-41) may have been constructed from bricks salvaged from 41HG156. Informant Edward Vela (1993) remembers that his father had bricks stockpiled at the site but that they eventually were stolen.

One final inference regarding brick manufacturing at $41 \mathrm{HG} 156$ is that Feature 14 suggests that the flat area north of the kiln and west of the waster piles may have been reserved for stacking fired bricks prior to their being loaded and transported. This is a logical area for stacking bricks because of its proximity to the kiln and the road.

\section{Summary of Features}

Many of the cultural features at 41HG156 are 


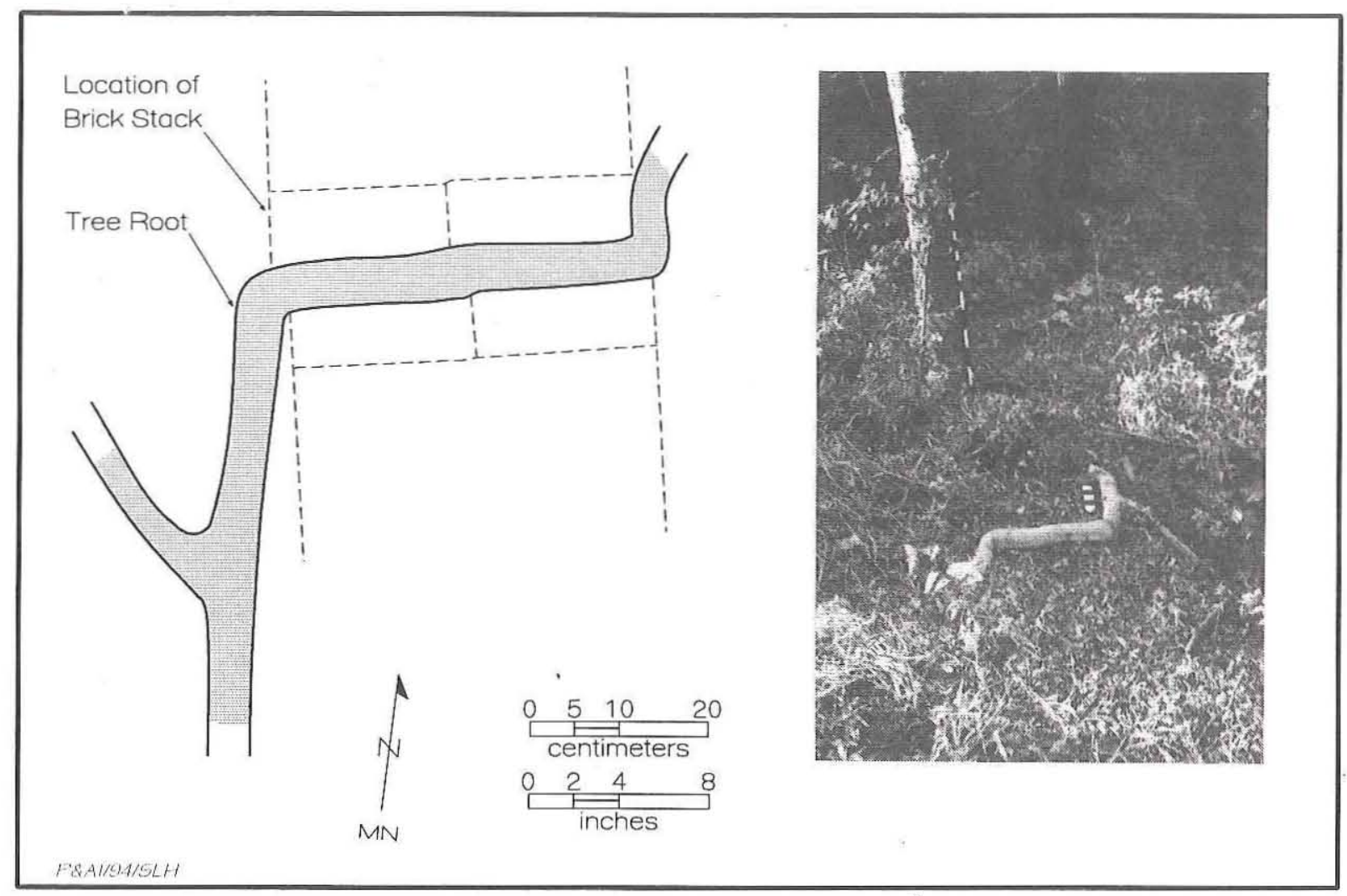

Figure 43. Plan view and photograph of Feature 14, 41HG156, showing modified hackberry tree root; note that the vertical $1-\mathrm{m}$ scale is resting on top of the brick embedded in the tree trunk.

definitely associated with the manufacture of bricks at this locality. The kiln and its adjacent mound of Type 1 brick fragments (Feature 1) is the most obvious component of the brick factory. This small kiln has walls that were constructed of adobe bricks (designated as Type 3 bricks) and a submerged firing chamber dug below the ground surface. The kiln had entrances on the east side and possibly on the south side as well. The kiln is relatively small and may have fired about 20,000 bricks at one time.

The large depression east of the kiln (Feature 8) almost certainly was a borrow pit that was the main, if not only, source of brick clay. It could easily have provided enough clay material for four to six kiln loads of bricks. A remnant of a brick stack (Feature 1A) and a modified hackberry tree root (Feature 14) provide incontrovertible evidence that there once were stacks of bricks north of the kiln. In addition, six discrete clusters of bricks (Features 2-7) are interpreted as waster piles. They are composed largely of fragmentary bricks, many of which exhibit evidence of having been overfired (i.e., warped, cracked, or partially vitrified bricks) or underfired (i.e., soft, crumbly, salmon-colored bricks). No mortar was observed in any of these features, and each feature contains only one kind of brick. Five of these waster piles (Features 2-6) are composed exclusively of Type 1 bricks, while the sixth (Feature 7) is composed exclusively of Type 2 bricks. Both of these types are hand-molded, sand-struck bricks, and the combined evidence indicates that brick Types 1 and 2 probably were manufactured at the site.

Many other features at 41HG156 are clearly the result of dumping and are unrelated to the brick factory. These dumps (designated as Features 8A$8 \mathrm{H}, 9,10,11 \mathrm{~A}, 12$, and 13) are in the form of discrete piles of structural debris, and most of the piles appear to approximate a pickup-load of material. These dumps are composed mainly of various types of bricks (28 different types), tile (1 type), and concrete mortar (see Appendix B). Many of the bricks have clay or concrete mortar clinging to them, and in some cases several bricks are still attached by mortar. 
One logical assumption can be made regarding the origin of these dump piles. It is unlikely that materials would have been transported great distances to be dumped at the site; hence, the dumped materials probably were derived locally. Variations between the features, in terms of their contents, suggest that the dumps were derived from different sources and perhaps at different times. If these inferences are correct, then it is likely that the dumps occurred within the last $30-40$ years as the expansion of agriculture necessitated the clearing of large tracts of land, including abandoned houses. Since World War II, almost the entire community of El Capote has disappeared under the plow, and it is possible that some of the dumps at $41 \mathrm{HG} 156$ represent the remnants of houses that once stood at El Capote or in nearby communities.

\section{Artifacts}

Three groups of surface artifacts were observed at $41 \mathrm{HG} 156$, but bricks are by far the dominant and most important type of artifact. Observations relating to all of the surface artifacts were made, but only bricks were collected. Fortyeight specimens, representing 33 different types of bricks, were collected (Table 22).

The first group of surface artifacts consists of brick piles and scattered bricks that are related directly to brick manufacturing at the site. Three different types of bricks present in Features 1-7 apparently were made on-site using local clays. Only two of these types, however, represent bricks that were manufactured for export (i.e., bricks that were intended to be used for building houses), while the third type represents bricks that were used in the construction of the kiln walls. Representative samples of these three types of bricks were collected, and three of the types are described in detail below. The manufacturing process and brick attribute terminology used in the descriptions is consistent with that used in Appendix B and is largely taken from Gurcke (1987).

The second group of surface artifacts consists of recent and historic bricks and debris associated with dumping episodes south and east of the kiln. Most of the dumping occurred in and around the clay borrow pit (Feature 8) east of the kiln, and the dump piles there are dominantly bricks and concrete/mortar fragments (see Table 19 for summary of dump Features $8 \mathrm{~A}-8 \mathrm{H})$. Besides the structural materials, these dump features also include recent debris such as glass bottles, plastic containers, and aluminum cans. A few probable historic artifacts (i.e., items over 50 years old) were noted, but the only diagnostic specimens were glass bottles with makers' marks dating to 19111929 and 1929-1954. Other dump piles south and southeast of the kiln (Features 9, 10, 11A, 12 and 13) are dominated by structural debris but also include some recent debris.

Bricks are the dominant diagnostic artifact in all 13 of the dump features, and 32 different types of bricks were observed. Representative samples of each of these brick types were collected. Since these dump features postdate the use of the kiln and are not related directly to brick manufacturing at the site, the collected specimens are not discussed here. Detailed descriptions of these brick types are presented in Appendix B.

The third group of surface artifacts is composed of a considerable amount of sheet refuse (i.e., recent trash such as beer bottles, plastic utensils, and soda pop containers) scattered in various parts of the site. The sheet refuse all appears to be modern and is concentrated in the flat areas north and south of the kiln. These materials undoubtedly are related to activities associated with the picnic area (41HG154) located immediately west of the site. This recent debris has little relevance to interpreting historic activities at $41 \mathrm{HG} 156$ and is not discussed further.

\section{Type 1 Bricks}

Type 1 bricks are present in and around the kiln (Feature 1) and in several waster piles located north of the kiln (Features 2-6). All of the surface evidence leaves little doubt that Type 1 bricks were made on-site, and based on the locations of the brick concentrations, Type 1 is interpreted as the most recent style of brick made at 41HG156. Four specimens (three complete and one fragment) collected from four different locations (i.e., Features 1, 2, 5, and 6) show the range of variability within this type (Figure 44). Complete bricks range in length from $205-222 \mathrm{~mm}$, in width from $95-100 \mathrm{~mm}$, and in thickness from $55-60 \mathrm{~mm}$ (the average is ca. $8.25 \times 3.75 \times 2.25$ inches). They vary in weight from $1,627-1,677 \mathrm{~g}$. 


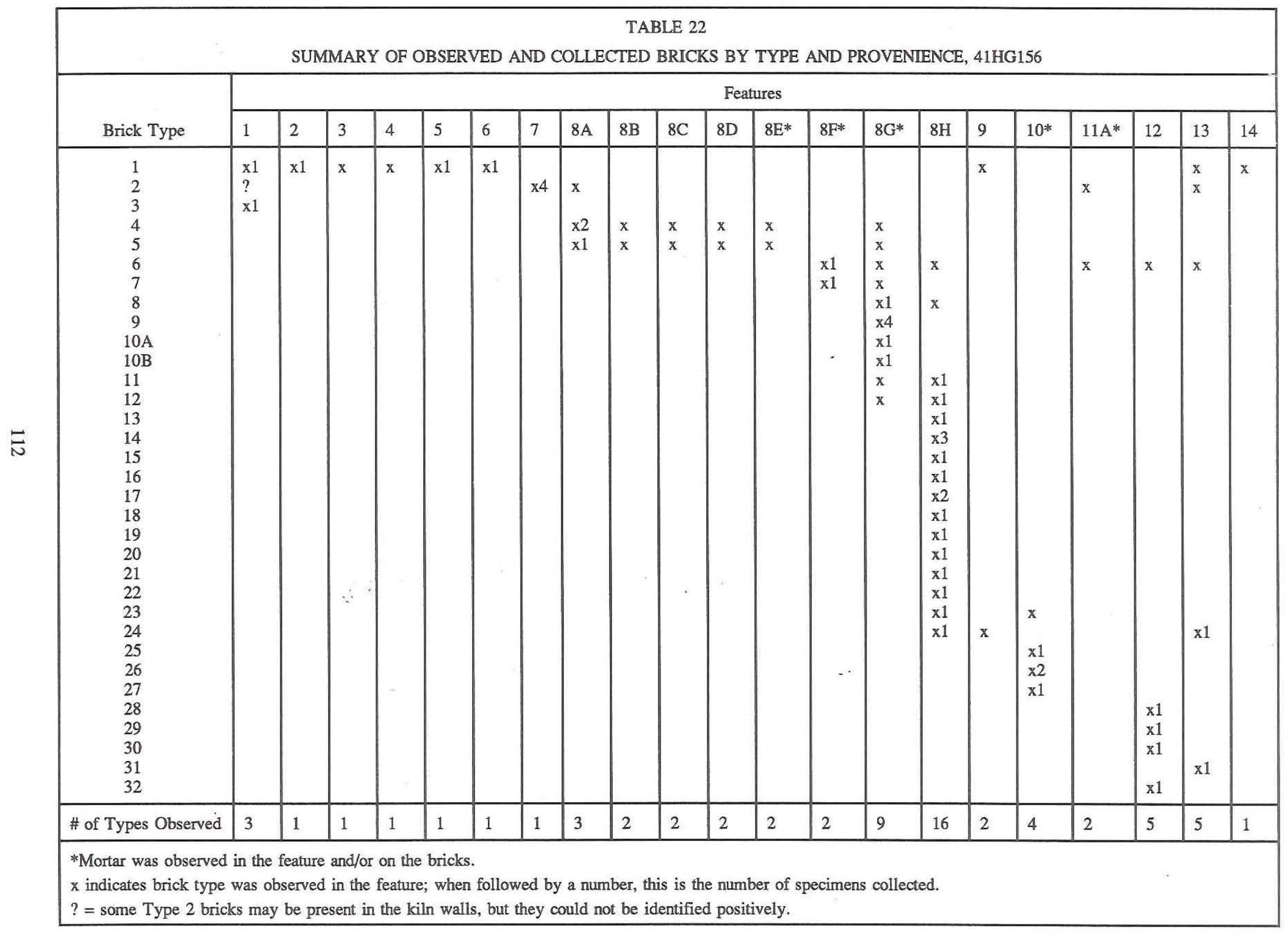




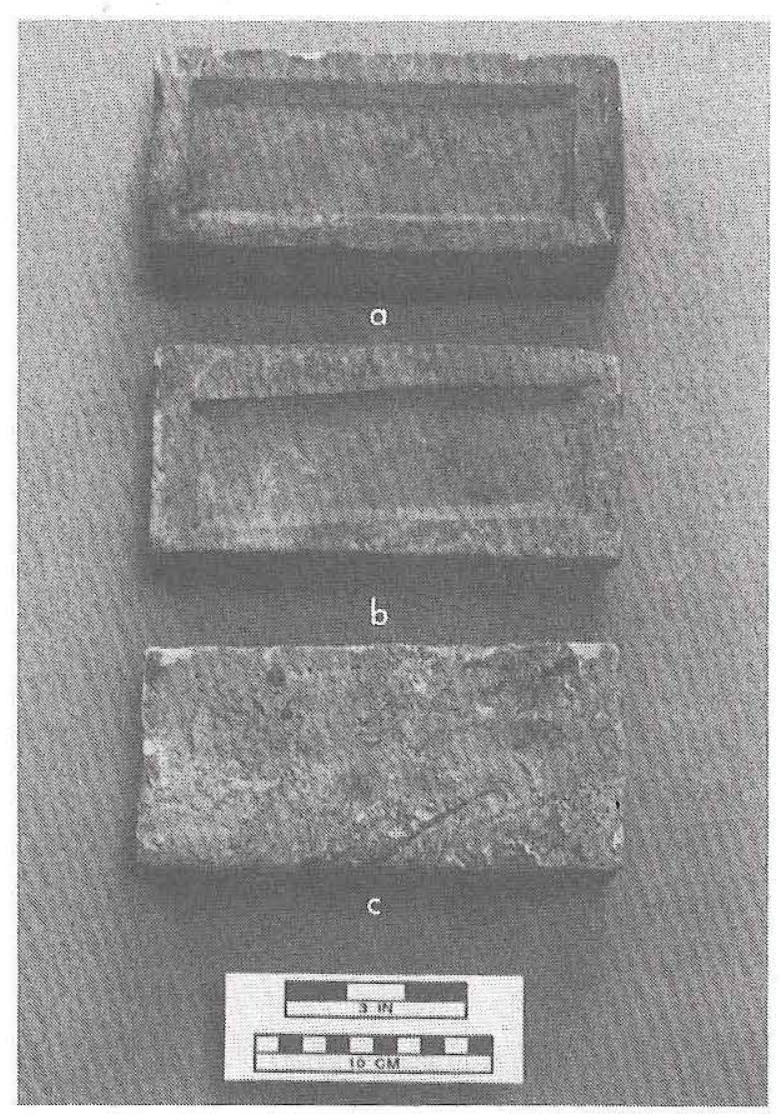

Figure 44. Type 1 bricks, 41HG156. $(a-b)$ Views of the molded faces showing variability in the size of the bricks and in the location of the frog; $(c)$ view of struck face showing rough texture and drag line indicating direction of strike.

Type 1 bricks have a single horizontal frog (indented panel) on the molded face, but no identifying markings were noted on any observed or collected specimens. The Type 1 frog is an impressed rectangular panel with faceted (inwardsloping) sides and a smooth bottom. The frogs range in size from $172-177 \mathrm{~mm}$ long by $60-65 \mathrm{~mm}$ wide and from 7-10 mm deep. Most of the specimens examined have the frog centered on the molded face, but several observed and one collected specimen have the frog off-center (see Figure $44 b$ ). All of these specimens are consistently similar, with the offset frogs always in the same orientation (skewed at a $5^{\circ}$ angle relative to horizontal), indicating that at least one brick mold had an improperly centered kick (i.e., the wooden block attached to the bottom of the mold to produce a frog).

The struck face has a rough vesicular texture, and some specimens exhibit irregular lines where inclusions were dragged across the face during the striking process (see Figure $44 c$ ). The molded face, both sides, and both ends are relatively smooth but have a sandy texture resulting from sand being used to lubricate the brick mold. Some bricks are very uniform in shape, while other specimens are rather irregular or even severely warped due to overfiring.

The bricks are generally pale brown to grayish brown (10YR $6 / 3$ to 10 YR $5 / 2$ ) on the exterior, while the interior (i.e., the color of the clay along a fresh break) is generally what would be called buff colored (very pale browns, 10YR 8/3-8/4 and 10YR 7/3-7/4). All of the corners and edges are rounded, and the bricks are very soft (i.e., hardness 3-4) indicating that they were fired at relatively low temperatures. All of the attributes noted for Type 1 bricks indicate that they were hand molded and sand struck using a soft mud process. The brick clay is rather porous, indicating that it was not well mixed.

\section{Type 2 Bricks}

Type 2 bricks are present in a single waster pile (Feature 7) located northeast of the kiln, and four complete specimens and one fragment were collected (Figure 45). The latter is a fragment that has what appears to be mud mortar still attached to its struck face, but it is an isolated specimen (i.e., not from the main pile). An examination of the main Feature 7 brick pile strongly suggests that Type 2 bricks were made on-site, but there is some element of doubt, leaving open the possibility that the Type 2 bricks represent a dump. Based on the location and characteristics of Feature 7 (including an absence of mortar noted on bricks in the main pile), Type 2 is interpreted as an earlier style of brick that was manufactured at 41HG156.

Type 2 bricks are hand molded with no apparent markings on any of the observed or collected specimens. Complete bricks range in length from 190-205 mm, in width from 92$98 \mathrm{~mm}$, and in thickness from 53-59. mm (the average is ca. $7.75 \times 3.75 \times 2.25$ inches). They range in weight from $1,365-1,779 \mathrm{~g}$. The exterior color is generally light gray to light grayish brown (10YR $7 / 2$ to $6 / 2$ ), while the interior is generally a very light buff color (white to very pale brown, 10YR $8 / 2$ to $8 / 3$ ). Other specimens have a slightly 


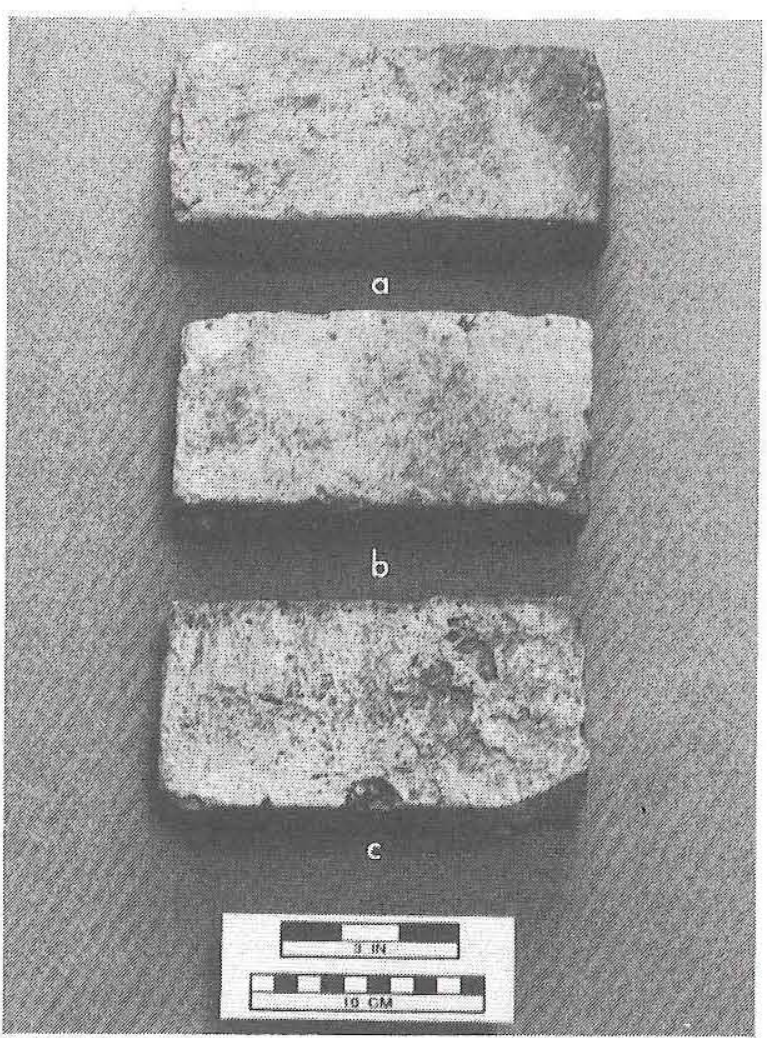

Figure 45. Type 2 bricks, 41 HG156. $(a-b)$ Views of molded faces showing variability in size; $(c)$ view of struck face showing rough texture and a Rabdotus shell inclusion along the bottom edge.

reddish tint (pink to reddish yellow, 7.5YR $7 / 4$ to $7 / 6$ ). The struck face has a rough vesicular texture, while the surfaces of the molded face, both sides, and both ends are relatively smooth but have a sandy texture due to the use of sand as a lubricant during molding. All of the bricks have rounded corners and edges and are quite soft (i.e., hardness 3-4), indicating that they were fired at relatively low temperatures. The brick clay appears to be poorly mixed, and Rabdotus shells were observed as inclusions in some Type 2 brick fragments. All of the attributes noted for Type 2 bricks indicate that they were hand molded and sand struck using a soft mud process. The Rabdotus shell inclusions provide evidence that they are made of local Rio Grande clays.

\section{Type 3 Bricks}

Type 3 bricks are large bricks that were used to construct the kiln walls (see Figure 41), and one fragmentary specimens was collected. The bricks used in the construction of the north wall and in the original construction of the south wall are fairly uniform in size and average ca. $500 \times 220 \times 80 \mathrm{~mm}$ (ca. $20 \times 8.5 \times 3$ inches). The reconstructed section of the south wall has eroded to the point where no complete bricks remain, but they are $220 \mathrm{~mm}$ wide and were probably $500 \mathrm{~mm}$ in length. They vary considerably in thickness, however, from $75-100 \mathrm{~mm}$. These bricks exhibit clear evidence that they were heated from the inside only. The interior surfaces exhibit heat discoloration (i.e, reddening) that becomes progressively less intensive and disappears toward the exterior (e.g., the collected specimen ranges in color from light brown to reddish yellow, 7.5YR $6 / 4$ to $6 / 6$ ). Thus, it appears that the kiln was constructed of unfired adobe bricks that were partially fired when the kiln was in use. Notably, Rab'dotus shells observed as inclusions in some of the Type 3 brick fragments provide good evidence that they are made of local Rio Grande clays.

\section{Discussion}

\section{Brickmaking at 41 HG156}

It is not clear exactly when the kiln was constructed and brickmaking first began at 41 HG156, but informants indicate that it was used by Pedro Guajardo until 1922 (Garza and Garza 1993) and later by Eduardo G. Vela from 19461948 (Vela 1993). There is no indication that the kiln was used between 1922 and 1946 . The kiln could have been built and used in the latter half of the nineteenth century by someone other that Guajardo, but he was born in 1875 (McAllen Genealogical Society 1976) and could not have used the kiln himself until the 1890s (when he was 15-25 years old). Few details about the kiln's early history are known, but it is possible that the bricks used to construct some early El Capote houses (such as the 1883 Ramirez house at 41 HG158 and the 1880s Cantu house at 41HG169) were made at $41 \mathrm{HG} 156$.

Much more is known about the kiln's latest use, however, and the following details were described by Eduardo G. Vela's son, Edward C. Vela (1993). Between 1946 and 1948, Eduardo G. Vela hired Mexican braceros to make bricks under the supervision of the Soto and Gallegos families, the latter having had experience in making bricks 
in Mexico. The informant thought that these people built the kiln, but it is more likely that they actually rebuilt the old kiln. It was only fired a few times during this short period, and the bricks were not sold but were made for Vela's own use. The informant noted that only five or six men worked at the kiln when it was in use and that the brick clay was obtained on-site. Mesquite was used as fuel.

There is some doubt as to why the Guajardo/ Vela kiln has a submerged firing chamber, but Foster (1970:70) notes that some kilns did have "fire-places built in their floors." However, this technique does not seem to have been very widespread, particularly in the Rio Grande Valley. There is also the possibility that gas firing may have been employed at $41 \mathrm{HG} 156$ at one time, but gas firing usually was restricted to commercial kilns with capacities of 50,000 or more bricks (Scott Cook, personal communication 1993). Problems such as these, however, cannot be resolved without further investigation.

While some of the details remain unknown, most of the brickmaking processes that were employed at the site can be inferred from the archeological evidence and from historical accounts that provide a clear picture of the steps necessary to transform raw clay into fired bricks. The following summary of brickmaking at $41 \mathrm{HG} 156$ is derived mainly from discussions of brick manufacturing processes with Robert Steinbomer (personal communication 1993) and from published accounts in Gurcke (1987) and Steinbomer (1980). A few other important references also warrant mention. Two articles on primitive brickmaking techniques are found in 1904 and 1914 editions of the trade journals Brick and Brick and Clay Record, respectively. These articles, "Burning an Up-Draft Kiln of Brick with Wood" (Vogt 1904) and "Where Brickmaking is a Side Line" (Anonymous 1914), provide good descriptions of different aspects of brickmaking. Another set of extremely informative documents is a series of historic accounts of brickmaking compiled and edited into three volumes by Foster $(1969,1970$, and 1971). One of these, Accounts of Brickmaking in America Published Between 1850 and 1900 (Foster 1971), is particularly enlightening regarding hand molding of bricks and the construction and use of small kilns.

Brick production at $41 \mathrm{HG} 156$ was a small- scale operation, and the site apparently is rather typical of brick factories, or ladrilleras, that were associated with ranches. As discussed later, the brickmaking tradition clearly came out of Mexico and was brought to the Texas Rio Grande Valley by maestros ladrilleros, or master brickmakers. These experienced brickmakers possessed all of the knowledge and skill necessary to organize a labor party to build a kiln, select a suitable clay source, and supervise the molding and firing of the bricks. Brickmaking by hand was, and still is, a very labor intensive process. While many of the steps were quite simple and easily accomplished with a sufficient labor force, placement of the bricks in the kiln and the actual firing were extremely critical tasks that required a highly skilled craftsman. Consequently, master brickmakers were very much in demand, and apparently almost all of them who worked in the Lower Rio Grande Valley had learned their skills in Mexican brickyards.

The archeological evidence indicates that the brickmaking process employed at $41 \mathrm{HG} 156$ was fairly standard, and it can be traced step by step across the site (Figure 46; compare with Figure 39). The process began with the selection of an appropriate clay source. Suitable brick clays are ubiquitous throughout the Lower Rio Grande Valley, but it is important to note that these clays are quite sandy and the end product is a relatively low quality brick. Steinbomer (1981:46-47) states that Mexican-made bricks are inferior (i.e., they are very porous and relatively weak) because typically they are poorly mixed and are fired at relatively low temperatures. However, he also suggests that the characteristics of the Rio Grande clays are partly responsible for the inferior quality (Robert Steinbomer, personal communication 1993). Although bricks of Mexican-style manufacture (i.e., any low-fired bricks made of Rio Grande clays) do not hold up well in wet or cold climates, they are quite adequate for many construction purposes in the arid Southwest.

At 41HG156, the large borrow pit (Feature 8) apparently served as the source of the brick clay, and it is likely that the raw material was usable without any nonplastic tempering agents being added. The borrow pit is estimated to have produced $146-216 \mathrm{~m}^{3}$ of sediment, or enough for approximately 80,000-120,000 standard-sized bricks (Gurcke [1987:116-117] suggests that 


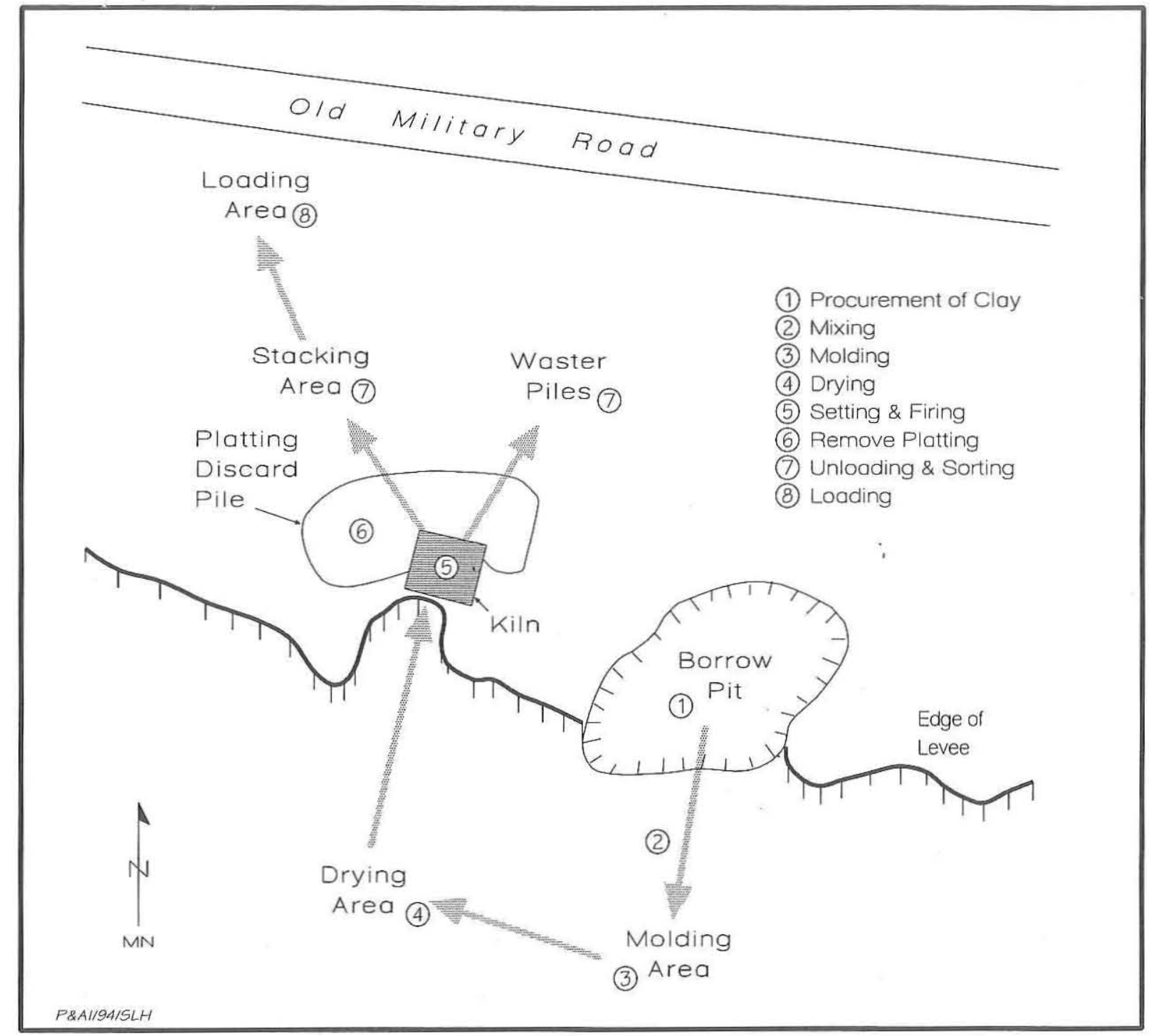

Figure 46. Schematic illustration of the brick manufacturing process at 41HG156.

standard American bricks generally range from 8-9 inches in length, 3-4 inches in width, and 2-3 inches in thickness). Notably, the pit was excavated directly into the edge of a levee that formed adjacent to a resaca. By doing this, the excavation progressed horizontally and it probably was easier to remove the clay in this manner than it would have been in a vertical pit on a flat surface. This may help explain why the kiln was constructed at this particular locality.

The next step was the mixing of the clay, which could have been done directly in the borrow pit or the clay could have been moved to the adjacent flat area south of the borrow pit to be mixed. It is unlikely that any kind of mechanized mixing (such as a pug mill) was employed at 41HG156. Most likely, the clay simply was mixed by "lumping it in a pile with water and then stomping around on it" (Steinbomer 1980:47). The plasticity of the clay was regulated by the amount of water that was added, and once it reached the right consistency, it was ready to be molded.

Molding at $41 \mathrm{HG} 156$ probably took place in the flat area south of the borrow pit. Hand molding was done in an assembly-line fashion with workers transporting the clay to, and the molded bricks away from, the molder. Unskilled laborers transported the raw clay and the molded bricks by 
hand or by wheelbarrow, but the master brickmaker commonly did the molding. He generally employed only a few simple tools - a molding table so that he could work standing up, a wood-frame mold with individual compartments for three to six bricks (Gurcke [1987:Figure 3] illustrates a wooden brick mold), and a striking tool (usually a sharp-edged wooden or metal instrument). The molder's tasks were generally as follows: (1) throw a premeasured lump of clay into the mold; (2) press and work the clay completely into the mold to fill all of the brick compartments and eliminate trapped airpockets; (3) scrape off, or "strike," the excess clay from the top of the mold; (4) turn the mold over to remove the molded bricks; and (5) lubricate the mold by sprinkling it with sand and/or water in preparation for the next molding. Depending on how many helpers there were, another worker might dump out the molded bricks and lubricate the mold while the master brickmaker continued molding with a second mold.

A worker carried the molded bricks from the molding table to a cleared level area and laid them out to begin the drying process. At $41 \mathrm{HG} 156$, this probably was done west of the molding area and south of the kiln. Drying required a large area because a good molder could produce " 3,000 brick in four to five hours" (Anonymous 1914:255), or as many as "5,000 to 7,000 per day" (Foster 1969:49). The bricks initially were laid out individually and were turned after several hours to expose other surfaces to the sun so that they dried uniformly. If space was limited, the bricks could be stacked into small groups of several hundred once they had dried sufficiently (i.e., for a day or so). The bricks were then dried anywhere from one week to a month (Anonymous 1914:255), depending upon many different variables such as the weather, the nature of the clay, whether they were laid individually or in stacks, and so forth. Drying at larger brickyards generally was done under sheds (as illustrated in Steinbomer 1980:photo following p. 70), but drying probably was done in the open (as illustrated in Anonymous 1914:253) at 41 HG153.

Molding and drying were repeated each day until the crew had molded enough bricks for a kiln load. In the case of the small kiln at 41HG156, which is estimated to have had a firing capacity of ca. 20,000 bricks, the molding probably took only 3-7 days, depending upon the number of workers and the speed at which they worked. After the bricks molded on the last day had dried completely, the process could move on to the next, and most critical, stages - loading and firing of the kiln.

Loading bricks into the kiln, or "setting the kiln" (Foster 1971:16), was very important. If the kiln was not set properly, the bricks would be fired unevenly, resulting in a considerable, and unnecessary, amount of over- and underfired bricks. Foster (1971:16-17) provides detailed descriptions of how setting was done, and these details are not necessary here, except to note that a good setting crew could "commence work at five o'clock in the morning and place 20,000 bricks in the kiln, and have their task completed by mid-day." The important points are that the setting of the bricks was supervised by the master brickmaker and was done in such a way as to leave arched channels through the bottom of the kiln and a small but uniform amount of space between all of the bricks so that the heat would be evenly distributed. Access to the firing chambers was through the arched openings, or "fireholes" (Vogt 1904:177).

With the kiln loaded, the critical task of firing then began. A.gain, this task was supervised by the master brickmaker, and the kiln was monitored 24 hours a day throughout the firing. Assuming that the kiln at 41HG156 was fired with wood fuel (see Foster [1971:18-22] and Vogt [1904] for detailed descriptions of wood firing in up-draft kilns), the process followed a very regular sequence of events. A large supply of wood that had been cut and allowed to season for several months was stacked near the kiln in preparation for the firing. Brickmakers generally allowed one cord of wood for each 2,000 bricks being fired (Foster 1971:42), and mesquite apparently was the preferred and most abundant wood in the Lower Rio Grande Valley (Anonymous 1912; Vela 1993). Small fires initially were started inside the kiln, built up slowly, and kept going for several days throughout the "water-smoke" period. During this time, the fire was kept low intentionally so the bricks did not heat too quickly, and the fireholes were left open at the bottom to allow maximum air flow. The kiln also was open at the top, but it might have a thin layer of waste bricks (i.e., unusable brick fragments), called "platting" (Foster 1971:19), placed loosely over the top to trap some of the heat but still allow the water-smoke to escape. The purpose of this preliminary firing was 
to drive off all of the moisture from the bricks before the true firing began. The water-smoke period was characterized by a white steamy smoke coming from the kiln, but once all of the water was driven off, the smoke turned darker and eventually black. The water-smoke period could last as little as 48 hours if the bricks were "bone dry" but usually lasted 3 or 4 days (Foster 1971:28-29; Vogt 1904:176).

The workers then gradually built up the fire in the kiln by adding wood and regulating the air flow into the fireholes until the kiln became "hot," and this intensive fire was maintained until the bricks "settled" (Foster 1971:19). During the hot period, each brick was expected to shrink slightly, but this varied considerably depending upon the type of clay. The experienced brickmaker was familiar enough with his brick clay to known how much to expect the kiln to settle. As the entire kiln load became fired and the bricks shrank, the top of the mass would drop down considerably. Foster $(1971: 21,32)$ says shrinkage generally averaged about $7.5 \%$ of the total height but that various types of clays could be expected to settle 6-18 inches per kiln load. The kiln usually would settle unevenly, and as it did, workers would monitor the fire, add wood to areas that were heating too slowly, and cover settled areas with a thick layer of platting to drive the heat out through the unsettled areas.

The intensive heating and settling usually lasted from 2 to 3 days (Foster 1971:33). Once the entire kiln load had settled and the fire was allowed to burn down, the fireholes were covered and more platting was added to the top, along with abundant clay, until the kiln was completely sealed. Workers carefully monitored the kiln to make sure that no more smoke or heat was escaping. At this point, the kiln was left to cool slowly for 1 or 2 days, or until the platting on top could be removed without burning the worker's hands.

When the kiln had cooled, the platting was discarded (i.e., simply tossed off the kiln) and the load of bricks could be removed. Every kiln firing had a certain amount of overfired or underfired bricks, and as the workers unloaded the kiln, the unusable bricks and fragments were tossed into waster piles while the usable bricks were stacked neatly in a level area to await loading and transporting. At $41 \mathrm{HG} 156$, the platting was discarded all along the north and west sides of the kiln. The waster piles and stacking area were located just north of the kiln, while the loading area probably was located even farther north adjacent to the Old Military Road.

\section{Brickmaking in the Lower Rio Grande Valley and Evaluation of 41 HG156}

In order to fully understand the Guajardo/Vela brick factory, one must consider it in relation to the brickmaking industry throughout the region. Although there is no definitive written history of the development of brickmaking in the Lower Rio Grande Valley, recent research by three individuals provides a clearer understanding of the regional context for 41HG156. During the 1970s and 1980s, Austin architect Robert Steinbomer conducted extensive resiearch on brickmaking throughout Texas, and although he has published some of his findings (Steinbomer 1980, 1981), much of what he learned remains unpublished. For the past decade, Anthropology Professors Scott Cook (University of Connecticut) and Joseph Spielberg (Michigan State University) have been working jointly on researching the brickmaking industry in the Rio Grande Valley of Texas and Mexico. Although their findings are not yet published, their research is critical to a complete understanding of $41 \mathrm{HG} 156$. All three of these scholars have shared freely their knowledge and the results of their research. The following summary and assessment are based mainly on their work.

Site 41 HG156 is a small-scale brick factory that, in its earliest days (perhaps from the late 1800 s to ca. 1922), was intimately tied to the community of El Capote. While some of the bricks made by Guajardo (and his predecessors, if any) may have been sold commercially, the brick kiln probably was never intended as a major commercial venture, and it is likely that most of the bricks were used mainly in and around El Capote (although this has not been confirmed). Even the site's last use episode, associated with Eduardo G. Vela in 1946-1948, occurred during the final days of El Capote, and although the bricks he made were used elsewhere, the kiln was still part of the community at that time. Consequently, 41HG156 is a good example of a ladrillera (brick kiln or brick factory) associated with a small ranching community. 
According to Joseph Spielberg (personal communication 1993), the "Ranch Period in Brickmaking" in the Lower Rio Grande Valley dates to ca. the $1840 \mathrm{~s}-1920 \mathrm{~s}$. There were brickmaking efforts that were not associated with ranches during this time, such as the brickmaking endeavor by the U.S. Army at Forts Brown and Ringgold, but ranch-related brickmaking was by far the most common occurrence. The broad pattern throughout the region was clearly one that involved traveling maestros ladrilleros (or master brickmakers) who came from Mexico and had learned their brickmaking skills there. Such individuals often brought with them and spread the knowledge of Mexican masonry traditions and were called maestros albanil-ladrilleros (or master bricklayer-brickmakers). The importance of these craftsmen cannot be overstated, and it has been noted that "the Mexican maestro albanil-ladrillero was critical in the evolution of the handmade brick industry in South Texas" (Scott Cook, personal communication 1993).

Apparently, many maestros ladrilleros traveled both sides of the Rio Grande, going from ranch to ranch to find work. When hired by a rancher, they would organize the local ranch hands to build a kiln, usually of adobon (large unfired adobelike bricks). The maestro ladrillero would then supervise the molding and firing of bricks that subsequently were used for constructing buildings on the ranch. Ranch brick kilns commonly were used on a periodic basis and often were abandoned temporarily and then used again at a later date.

There are only a few documented cases of ranch-related brick kilns that sprang up in the region, although almost "every ranch probably made brick on a small scale" at one time or another (Joseph Spielberg, personal communication 1993). Downstream from El Capote, there were brick kilns at two other Hidalgo County ranches - Relampago Ranch (4 miles south of Mercedes) and Toluca Ranch ( 3 miles east of Progreso) - and at Rancho de Santa Maria (1 mile east of Santa Maria) in Cameron County. These locations are mentioned in the Texas Historical Commission's Hispanic Texas: A Historical Guide (Simons and Hoyt 1992:246, 252, 259-260, 263). Like El Capote, all of these ranches were located on or near the Old Military Road (the route now approximated by U.S. Highway 281), and churches built of bricks made on-site at Toluca Ranch (St.
Joseph's Church, built in 1899) and at Santa Maria (Our Lady of Visitation Catholic Church, built between 1880-1882) are still standing.

Ultimately, the commercial brick industry evolved out of the Mexican-influenced Ranch Period brickmaking tradition around the turn of the century. Brick production at most ranches probably began on a small-scale basis, but many ranch kilns evolved into successful larger scale commercial operations. This appears to be the case with brick manufacturing at the Santa Maria (reported to have had 3 kilns, each with a capacity of 30,000 bricks) and Relampago (reported to have had 10 kilns of unknown capacity) ranches, for example. Notably, the Santa Maria Ranch served as a U.S. Army subpost of Fort Brown and Fort Ringgold in the 1850s (Simons and Hoyt 1992:262) and may have provided some of the bricks used in construction at these forts. Still other commercial brick plants came into the region and set up as large-scale producers from the start, but even these were heavily influenced by the Mexican brickmaking tradition. Large brick plants such as the one started in Harlingen in ca. 1909 by Lon C. Hill (Anonymous . 1912) clearly made bricks by traditional methods learned from Mexican brickmakers. The same is true for the large brickyards run by the German immigrants Heinrich Portscheller, who operated a plant between 1886 and 1907 in Roma (Simons and Hoyt 1992:256; Steinbomer 1981:45), and Guenther Weiske, who started a plant at Madero (south of Mission) sometime before World War I (Scott Cook, personal communication 1993; Joseph Spielberg, personal communication 1993). Even the twentieth-century brick plants in Edinburg, Harlingen, and elsewhere in the region apparently grew out of the Mexican ladrillero tradition. According to. Steinbomer (1981:44), Texas brickmaking has its roots in the Spanish and Mexican settlers who came equipped with "an expert working knowledge of brickmaking and brick masonry construction."

Small-scale brick production using traditional methods is still being done at some plants in Mexico, but the last small-scale brick factory on the United States side went out of business in 1980 (Scott Cook, personal communication 1993). Large-scale brick production is still a major industry in Mexico, and as late 1980, Mike Butler, President of the Brick Institute of Texas, estimated 
that "as much as 50 percent of the brick sold in Texas comes from the 84 brick plants operating less than five miles south of the Texas-Mexico border" (Steinbomer 1980:69, 1981:47). Conversely, Steinbomer (1980:70, 1981:47) noted that "in 1980, there remained only 21 producers with a total of 30 plants in operation within the geographic confines known as Texas" and that this was the "lowest number of operating brick plants in the State since 1870." Competition with Mexicanmade products may be partly responsible for the decline in Texas brick production, and Butler attributed "the demise of 17 Texas brickmakers since the early 1960s" to this "lethal competition" (Steinbomer 1980:69-70, 1981:47).

Except for the recent unpublished research by Cook and Spielberg, not much is known about the details of brickmaking at ranching sites and the eventual development of the commercial brick industry in the Lower Rio Grande Valley (Scott Cook, personal communication 1993; Joseph Spielberg, personal communication 1993). To the author's knowledge, there has been no significant archeological investigation of any ranch-related brick kilns anywhere in the region. In fact, the brick kilns at the three ranching sites mentioned above apparently are gone, and the Guajardo/Vela kiln at 41HG156 is the only ranch kiln known to exist in the entire region. Scott Cook (personal communication 1993) summed it up best: "In short, site 41 HG156 is of considerable historical importance as probably the best-preserved, and possibly only extant, ranch brick plant site dating from the late 19th century."

Site 41 HG 156 cannot be considered significant because of its association with important individuals (National Register Criterion B), but it does constitute a rare and well-preserved example of a Ranching Period small-scale brick factory and is representative of a site type that was once ubiquitous in the Lower Rio Grande Valley (Criterion C). It also appears to be representative of a once widespread and important cottage industry that no longer exists in Texas (Criterion A). For these reasons, and because of the site's high integrity, it has the potential to yield significant information through intensive archeological investigation (Criterion D). Thus, it is recommended that site 41HG156 be considered eligible for listing on the National Register of Historic Places (under Criteria A, C, and D) and for designation as a State Archeological Landmark.

\section{HG158, RAMIREZ STRIP}

\section{Site Setting}

Prehistoric and historic components at 41HG158 are located along the southern edge of a flat, featureless alluvial terrace (see Figure 13). An unimproved farm road runs east to west through the site along the terrace edge, which is $1.0-1.5 \mathrm{~m}$ higher than the next terrace to the south (Figure 47). The slope of the terrace forms the southern boundary of the site, but the majority of the site is contained within the agricultural field to the north. At the time of investigation, the field had been plowed recently and was devoid of vegetation. The site covers an area of $120 \mathrm{~m}$ north-south by $450 \mathrm{~m}$ east-west and lies' at an elevation of $95 \mathrm{ft}$ above mean sea level. The site is called the Ramirez Strip and is named for a thin north-south strip of land owned by the Ramirez family after the porción was divided up. The $450-\mathrm{m}$-wide site, however, extends on its east and west sides beyond the boundaries of the 450-ft-wide Ramirez Strip which comprises the central portion of the site.

\section{Previous Investigations}

Site 41HG158, located through historic map studies and local informant data, was recorded during the 1992 survey (Kibler and Freeman 1993:46-49). The prehistoric component, confined to the extreme western end of the site, was described as a small, low-density surface scatter of lithic debitage and mussel shell fragments, and a single chert flake was collected. The historic component was described as a consistent scatter of surface artifacts across the upper terrace and down the slope of the terrace edge. Two shovel tests along the terrace edge in the central portion of the site yielded numerous brick and mortar fragments, charcoal, and two metal and two glass artifacts from $0-60 \mathrm{~cm}$ below the surface. Surfacecollected artifacts $(n=17)$ consist of one cut bone fragment, five glass bottle fragments, two brick fragments, one metal artifact, and eight ceramic sherds. Diagnostic ceramic sherds include flow blue (ca. 1840-1870), dark blue transfer-printed ware (ca. 1820-1860), and Bristol glaze stoneware (post-1910), but yellowware, porcelain, and soft- 


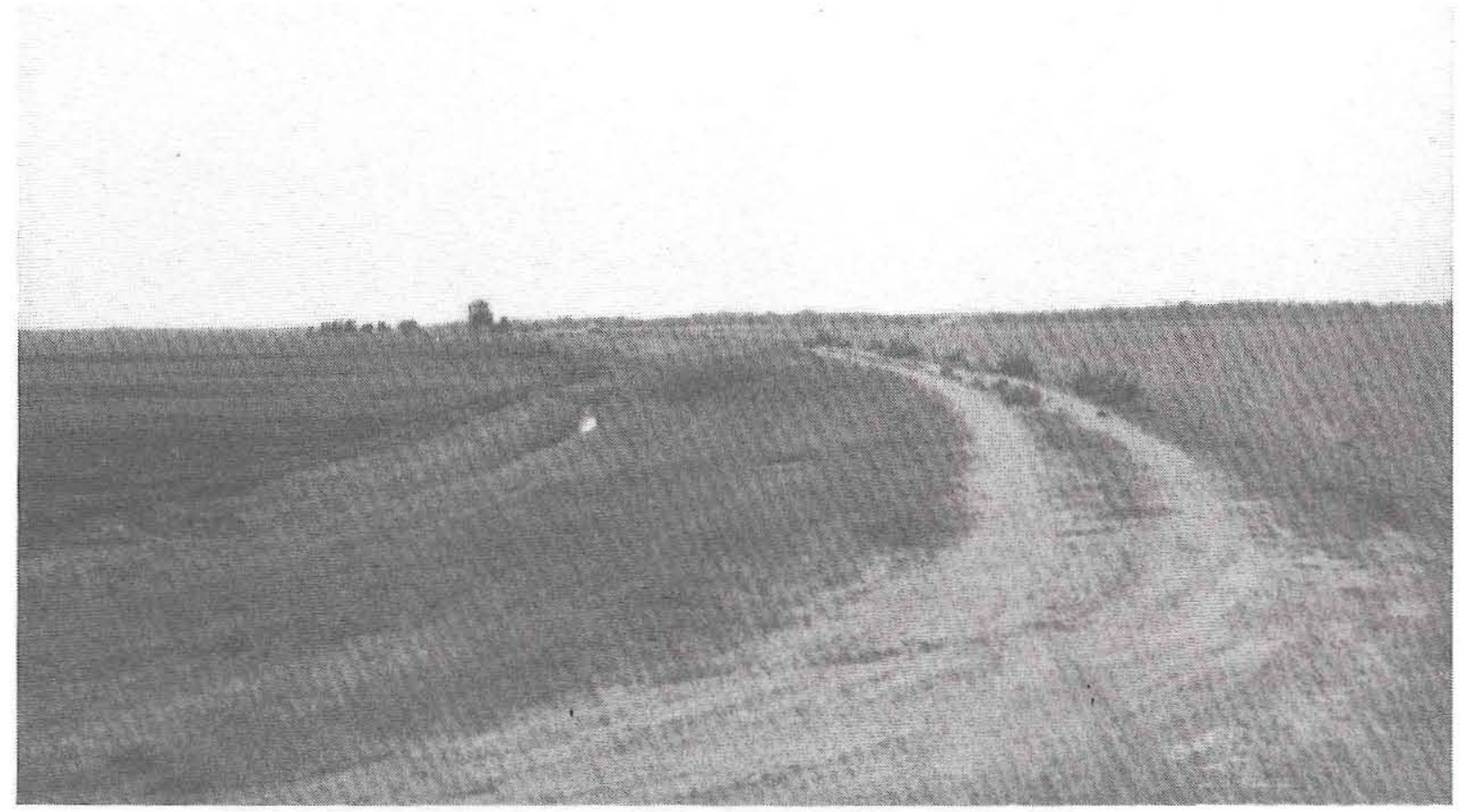

Figure 47. Overview to the west of 41HG158; El Capote Cemetery (41HG155) is in the isolated group of trees in the background.

past Mexican wares also were recovered. Based on the diagnostic attributes, glass specimens were dated to pre-1900, post-1904, and ca. 1875-1906. Historic archival and informant studies identified 41 HG158 as the location of several separate housesites. The Luis Arebalo adobe house occupied the western end of the site, and a group of houses that informants most commonly attribute to the Ramirez family occupied the remainder, i.e., the 450-ft-wide Ramirez Strip. The easternmost house was reported to have been built of bricks in 1883 and occupied until the 1940 s by the Ramirez family.

The prehistoric component at $41 \mathrm{HG} 158$ was assessed as having a low research potential, and it was recommended that it be considered ineligible for listing on the National Register of Historic Places and for designation as a State Archeological Landmark. The historic component, however, was considered to have potential for yielding information relating to the development of El Capote Ranch community. It was recommended as being potentially eligible for listing on the National Register of Historic Places and for designation as a State Archeological Landmark, and further testing was recommended.

\section{Work Accomplished}

Investigation of the historic component at 41HG158 included additional archival and oral history research, transit mapping of the site, controlled surface collection of selected diagnostic artifacts, and mechanical testing to search for buried features (Figure 48). The additional historic research and airphoto study indicated that the Carlos Casarez housesite had been located east of the Ramirez house, in the far eastern end of the site.

The initial field inspection revealed that there is a rather continuous, low-density artifact scatter east-west along the terrace-edge road, encompassing the entire area where several housesites were reported to have been located. There are no apparent breaks in the artifact scatter, but surface artifact density varies slightly from east to west. Artifact density varies considerably from north to south and is highest in the terrace-edge road, along the terrace slope immediately south of the road, and into the plowed field within $20 \mathrm{~m}$ of the road. Artifact density is exceedingly sparse in the plowed field beyond about $20 \mathrm{~m}$, but an occasional artifact could be found. The site size is estimated 


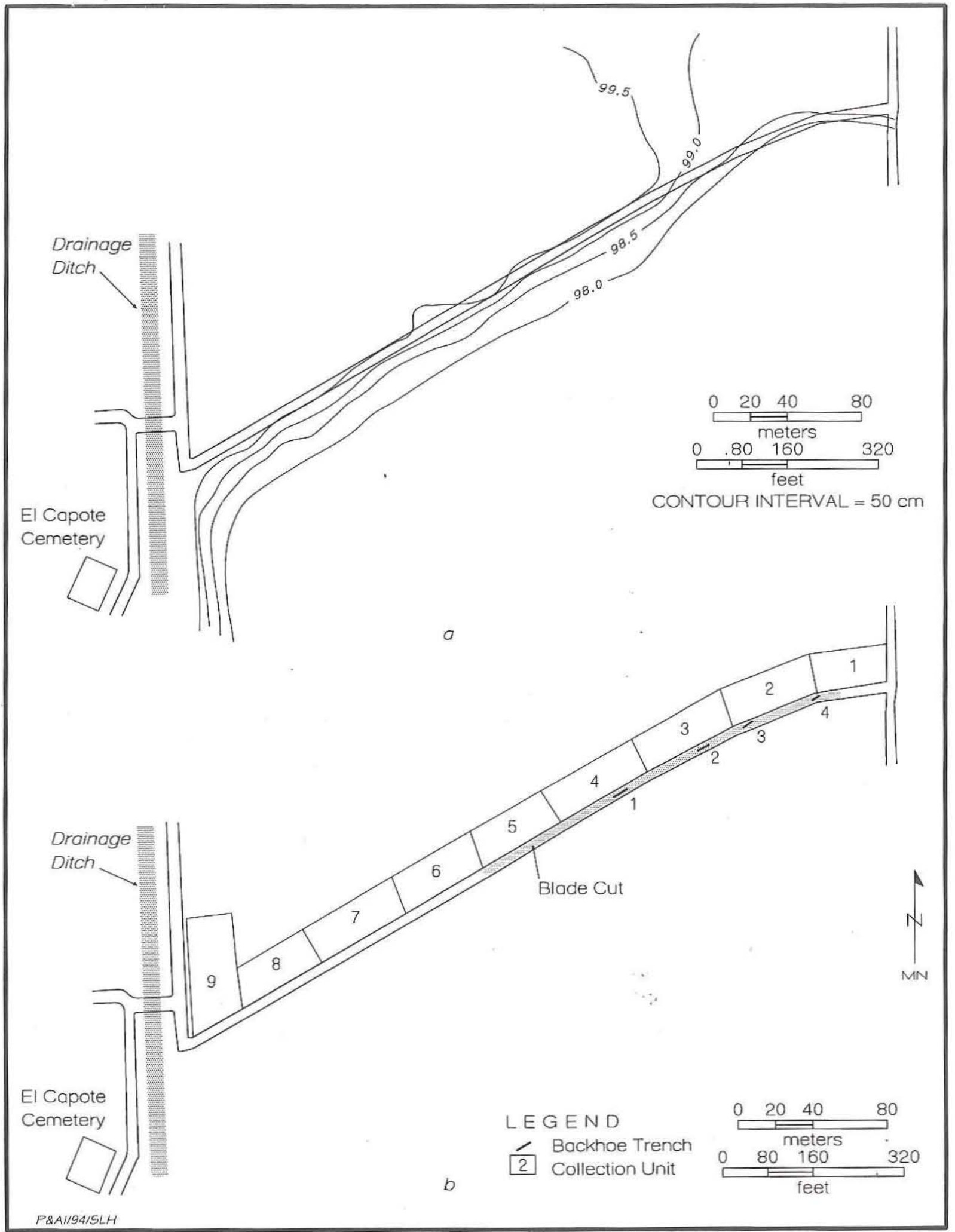

Figure 48. Site maps of historic component at $41 \mathrm{HG} 158$ showing (a) surface topography and $(b)$ locations of mechanical excavations and surface collection units. 
to be approximately the same, ca. $450 \mathrm{~m}$ east-west by $120 \mathrm{~m}$ north-south, as observed during the 1992 survey.

Since the artifact density was so low and there were no definable concentrations, the entire site area was gridded off, from east to west along the terrace-edge road, into nine 50-m-long segments. Each segment served as a surface collection unit and was traversed at closely spaced (i.e., 5-8-m) intervals for a distance of $10 \mathrm{~m}$ south of the road and $20 \mathrm{~m}$ north of the road. Within each of these $30-\mathrm{x}-50-\mathrm{m}$ areas, all functionally and/or temporally diagnostic artifacts were collected, and all nondiagnostic artifacts were quantified.

Mechanical testing consisted of maintainer blading to search for buried historic features, followed by backhoe testing to provide deep stratigraphic profiles. A $200-\mathrm{m}$-long maintainer blade cut was made in the central and eastern portions of the site where the older housesites were thought to have been located. While some scattered artifacts were found in the backdirt from the blade cut, only one buried feature, a concentration of brick fragments and historic artifacts recorded as Feature 1, was encountered (see Feature). Four backhoe trenches then were excavated to provide deep stratigraphic profiles in order to determine the nature of the buried historic component. All of the trench profiles were inspected, and stratigraphic profiles were described for two of the trenches (see Appendix A).

The additional archival research (see Site History), along with a review of historic maps and airphotos and additional oral history research, revealed new information that indicates that the 450-m-long site encompassed at least three, and possibly as many as five, historic housesites attributed to various people. The site area definitely includes the locations of the former Luis Arebalo adobe house in the western end of the site, the Ramirez brick house in the east-central portion of the site, and the Carlos Casarez house in the eastern end of the site. In addition, it is possible but cannot be confirmed that the Luca Gonzales No. 1 jacal was located in or near the western end of the site and a second Ramirez house of unknown construction may have been located in the central portion of the site.

\section{Site Stratigraphy and Sediments}

Site 41 HG158 is situated on the margin of a
Holocene alluvial terrace (T1) that overlooks an abandoned channel of the Rio Grande and modern floodplain (T0) to the south (Kibler and Freeman 1993). Soils at this locality are mapped as Camargo silty clay loam (an Entisol), Reynosa silty clay loam (an Inceptisol with an ochric epipedon), and Harlingen clay (a light-colored, montmorillonite-dominant Vertisol) (Jacobs 1981:171).

The site stratigraphy and sediments were examined through the excavation of four backhoe trenches. Profiles from two of the backhoe trenches were recorded in detail (see Appendix A) and are discussed below in terms of site formation, context, and integrity (Figure 49). The formation of the T1 and T0 surfaces is discussed in more detail in the Site Stratigraphy and Sediments section of site 41HG153. The following discussion focuses primarily on: the development and modification of the current $\mathrm{T} 1$ surface and historic occupation surface.

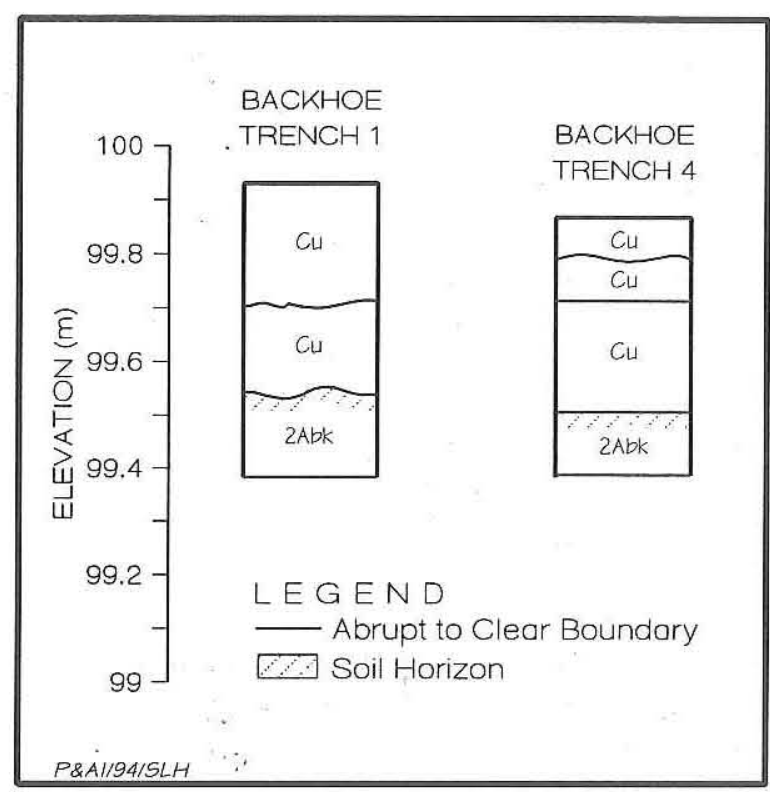

Figure 49. Geomorphic profiles of Backhoe Trenches 1 and 4 at $41 \mathrm{HG} 158$.

Backhoe Trench 1 was excavated to $108 \mathrm{~cm}$ below the surface at the location of Feature 1 after the feature was excavated. Three zones were identified within the profile. Zones $1(0-45 \mathrm{~cm})$ and $2(45-77 \mathrm{~cm})$ represent a grayish brown to dark grayish brown clay to clay loam fill that was laid down along the edge of the terrace for a roadbed and to maintain the integrity of the terrace 
edge. The fill appears to have been put down after the demolition of the houses and other structures occupying the site because intact structures and/or foundations were not present in Zones 1 and 2 . Historic artifacts and debris, such as glass, ceramic, and brick fragments, are commonly dispersed throughout Zone 1 and increase in number in Zone 2. Charcoal is common throughout Zones 1 and 2, and many of the artifacts appear to be burned. The artificial fill overlies the natural terrace surface, represented by Zone 3 . Zone 3 $(77-108+\mathrm{cm})$ is a moderate fine blocky brown clay with common $\mathrm{CaCO}_{3}$ filaments and is devoid of historic materials. Zone 3 is a buried soil, classified as a $2 \mathrm{Abk}$ horizon.

Backhoe Trench 4 was excavated to $96 \mathrm{~cm}$ below the surface, and four zones were identified within the profile. The profile is very similar to that of Backhoe Trench 1, revealing recent road fill overlying the natural terrace surface. Zones 1-3 $(0-72 \mathrm{~cm})$ represent the recent artificial fill, which is comprised of a brown to dark grayish brown clay to silty clay loam. As in Backhoe Trench 1, historic artifacts and debris consisting of ceramic, glass, and brick fragments increase in number down-profile to $72 \mathrm{~cm}$ below the surface. Charcoal is prevalent throughout the zones, and many of the artifacts appear to be burned. Intact structures or features were absent. The artificial fill overlies the natural terrace surface, represented by Zone 4 . Zone $4(72-96+\mathrm{cm})$ is a moderate fine blocky brown to dark brown clay loam with few $\mathrm{CaCO}_{3}$ nodules. Zone 4 is a buried soil, classified as a $2 \mathrm{Abk}$ horizon.

It is fairly clear that much of the historic occupation surface of $41 \mathrm{HG} 158$ is now buried, truncated, or greatly disturbed. It would appear that the structures were demolished, the debris burned, and the land graded to the terrace edge for road fill. Debris is scattered throughout the road fill, and intact features and structures are absent. The artificial fill is clearly separate from the underlying natural surface, which is void of historic materials and appears to be truncated as at 41HG153. If this is the case, the underlying stratum would unquestionably predate the historic component and is unlikely to contain intact structures or features. Deep plowing and land leveling north of the road for agricultural purposes probably also has rendered disrupted cultural deposits and poor site integrity; however, this was not demonstrated through excavation due to constraints on site access. The interpretations made of the site stratigraphy at $41 \mathrm{HG} 158$ leave very little potential for the presence of intact structural foundations, features, and historic deposits and occupation surfaces.

\section{Site History}

Site $41 \mathrm{HG} 158$ is located on the western edge of the Juan Antonio Velasco Porción 70, a grant made by the crown of Spain in 1767 and confirmed to the heirs and assigns of Velasco in 1852. Velasco held Porción 70 until December 24, 1793, when he conveyed it to Marcos Farías (Deed Record I:474-476). Farías sold the grant on June 13, 1800 to Pedro Villareal (Deed Record I:479483). Local informants and deed records suggest that the area recorded as site $41 \mathrm{HG} 158$ may have been the location of at least three separate improvements. Informants, for example, recall that the westernmost portion of the site was the location of a twentieth-century adobe house occupied by El Capote resident Luis Arebalo (Garza et al. 1992). More than likely, however, the house was not adobe, but a casa de reboque. It was actually on the land owned by Abran (or Adán) Guadalupe Ramirez (Figure 50), son of Manuel Ramirez, and leveled in 1940 for farmland (Ramirez et al. 1993).

Immediately east of the Arebalo house was a piece of land approximately $450 \mathrm{ft}$ wide that was known as the "Ramirez Strip" and was owned successively by Manuel Hinojosa, José Flores, María Rosaria Flores, and María Antonia Gusman, a lineal descendant of Flores, who sold it to Roland Ritchey on September 4, 1857 (Deed Record A:323-324). Ritchey or his heirs held the property until 1869 when they sold it to Juan Flores (Deed Record B:362). Artifacts collected at the site suggest that the Flores, Ritchey, and/or Juan Ramirez families may have occupied the central portion of the site during the mid nineteenth century.

In 1898-1900, Hidalgo County Sheriff John Closner and his partner, James B. Wells, acquired acreage in Porción 70 from members of the Garza family and other property owners (Deed Record I:56-57). Closner and Wells sold 2,139.80 acres in Porción 70 to J. P. Withers of Kansas City, Missouri (Deed Record J:501-504). Most of Porción 70 was purchased by Charles Hammond, 


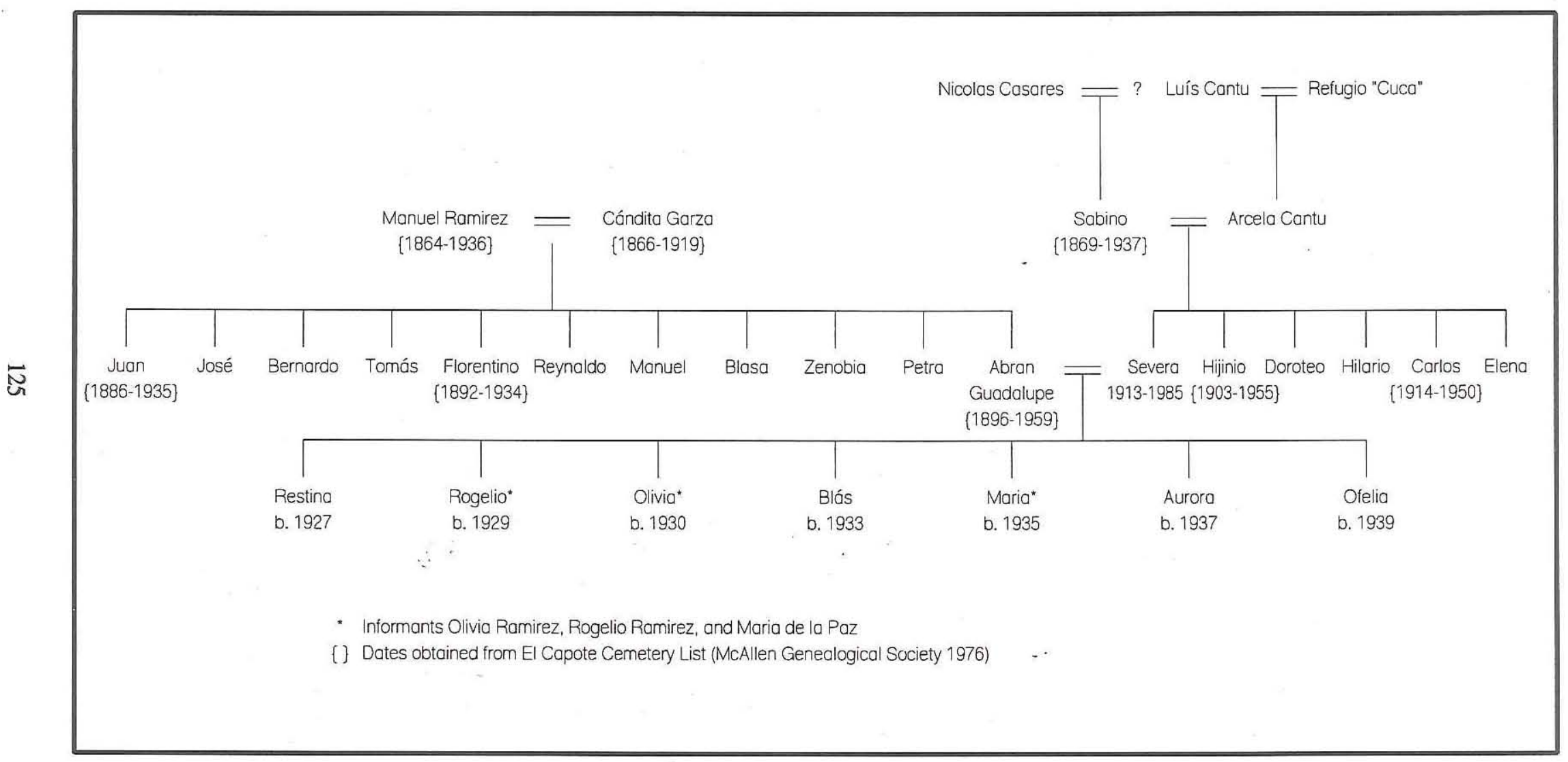

Figure 50. Genealogy of E1 Capote Ramirez family. All data are from informant interview (Ramirez et al. 1993) unless otherwise stated. 
who sold a half interest to John C. Kelly of Waco, Texas (The Pharr Press, February 13, 1959). John C. Kelly then confirmed land on which site 41HG158 is located to Manuel Ramirez (Deed Record 28:443).

According to local informants (Dyer and Norton 1992; Garza et al. 1992), one of whom has an 1883 date brick from the site, the eastern portion of the site was the location of a rectangular-shaped brick house occupied by the Ramirez family. This was the Ramirez house until the family fell into arrears on taxes and sold the surrounding 220 acres to Fred W. Turner of Weslaco in 1940 (Deed Record 475:490). According to Manuel Ramirez's granddaughter and an occupant of the house, Olivia Ramirez, the building was made of handmade brick and had a gable roof of thatching (techo de dos aguas de sacate). Constructed in 1883 , it had a main room about $15 \mathrm{ft}$ wide and twice as long, a kitchen with a fireplace (chimenea) and a six-plate woodburning stove, a small living room (salita), and a bedroom with three beds (Ramirez et al. 1993). Other local residents described the home as having functioned also as a store and noted that it had ornate ironwork at the windows and carved vigas of cypress (Dyer and Norton 1992).

Turner and his wife, Pauline M. Turner, sold the 220 acres to Roy W. Barnes in 1943 with a deed record that added that "Said above tract is also sometimes known as El Capote Ranch" (Deed Record 510:31). Then in 1973 the Barneses deeded the tract over to their sons, Jack L. and Randall Lance, who now rent it to Elmo Stone (Deed Record 1358:737; Ramirez et al. 1993). The Ramirez family lived in the house from the time of its construction until ca. 1944. It was subsequently rented out to Mexican workers but eventually was abandoned and began to deteriorate. In about 1980 , the house was demolished and the site was leveled (Ramirez et al. 1993).

The third housesite known to have been located at 41HG159 is the Casares (Casarez) house, which was in the far eastern end of the site. Olivia Ramirez (Ramirez et al. 1993) stated that this casa de reboque was the home of Carlos Casares and his wife, Luz Cantu, but it was destroyed about 1935 when the surrounding fields were cleared. Michigan State University Anthropology Professor Joseph Spielberg (personal communication 1993) remembers visiting El Capote, where he was told that his great-grandfather, Benigno Casares, was the individual who first lived in and may have built the Casares house northeast of the cemetery.

\section{Feature}

Feature 1 is a $7-\mathrm{m}$-long concentration of historic debris at $50-60 \mathrm{~cm}$ below the ground surface (i.e., Zone 2 in Backhoe Trench 1). It appears to be a random jumble dominated by fragmentary bricks, but it also includes historic artifacts, charcoal flecks, and orange (oxidized) clay lumps (Figure 51). All of the bricks and debris appear to be lying on a horizontal surface and are immediately overlain by a $30-40-\mathrm{cm}$-thick capping layer of artificial fill which was used to build up the road (see Sediments and Stratigraphy). The capping layer is composed of sediment containing some historic artifacts and modern debris, such as plastic shotgun shells.

All artifacts associated with this feature were collected except for bricks which were too fragmentary and numerous. Two of the larger brick fragments were collected, however, and one of them has a probable cattle brand mark that appears to be a backward "R" (see Artifacts Collected and Observed). Brick fragments that were not collected consist of five large fragments that are greater than $10 \mathrm{~cm}$, six medium-sized fragments that are $5-10 \mathrm{~cm}$, and numerous small fragments that are less than $5 \mathrm{~cm}$. The Feature 1 assemblage contains nondiagnostic undecorated whiteware sherds and an earthenware tobacco pipe fragment. The diagnostic glass from the feature consists of types ranging from the first half of the nineteenth century, the Civil War through World War I, and the twentieth century.

Feature 1 is in closest proximity to the location of the former Ramirez brick house (as shown on the 1962 USGS 7.5' Las Milpas quadrangle, for example), and it seems certain that it is somehow associated with that housesite. The presence of brick fragments in Feature 1 supports the idea that it is associated with the Ramirez house since this was the only house in the site area that was made of bricks. Exactly how this feature relates to the former Ramirez housesite, however, is not absolutely clear. The random jumble of debris comprising Feature 1 appears to be a secondary deposit, but there are at least three possible interpretations for its origin. One 


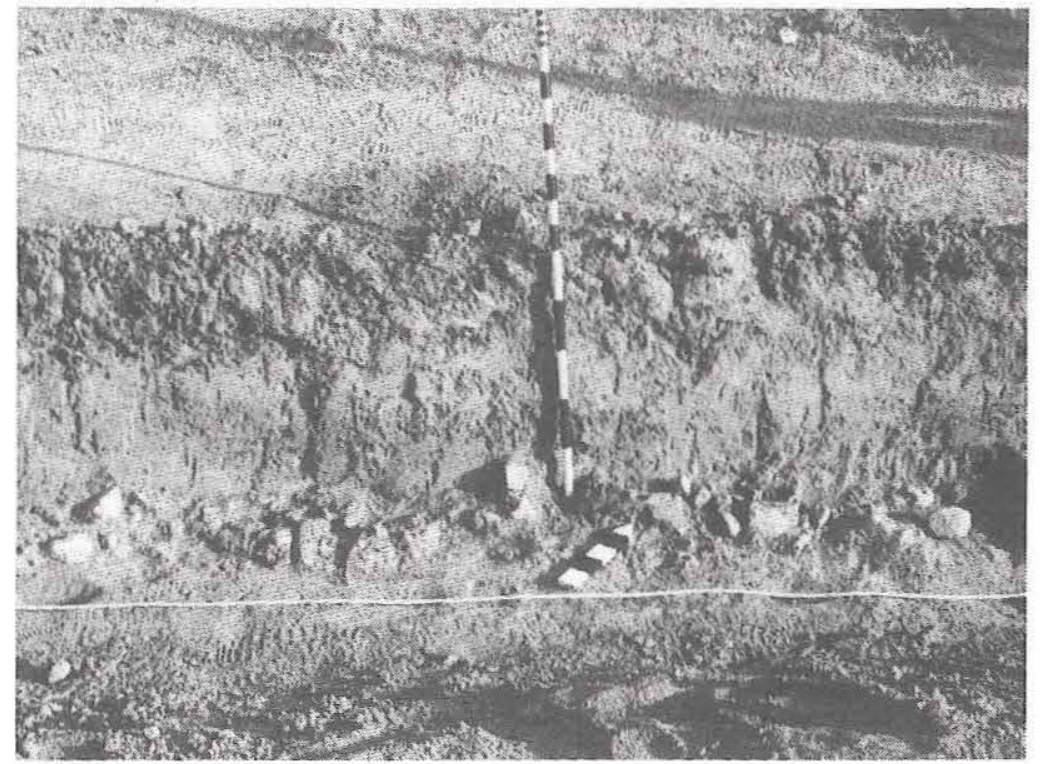

Figure 51. View north of Feature 1 exposed in blade cut, 41HG158. likely scenario explaining Feature 1 is that piles of vegetation were bladed, along with what remained of the Ramirez house (after most of it had been hauled off or salvaged), to the edge of the terrace and burned. During subsequent land leveling, more capping sediment was put along the terrace edge, and the modern roadbed is $50-70 \mathrm{~cm}$ higher than the original ground surface.

\section{Artifacts Collected and Observed}

Cultural materials observed consist of 422 specimens (Table 23). In addition, ceramic, glass, brick, cuprous, ferrous, bone, and interpretation is that it is the actual housesite location but that it has been disturbed; however, this is not likely given that informant and historic map data clearly indicate that the actual housesites were located well north of the modern terrace-edge road. A second interpretation is that Feature 1 is part of an intact dump area associated with the housesite. This alternative is not particularly likely because it does not explain the large amount of fragmentary bricks present since such quantities would not be expected in a typical household dump. This interpretation also fails to explain the disturbed nature of the sediments containing Feature 1.

The third interpretation is that Feature 1 represents structural debris and artifacts that were removed from the housesite and dumped on the edge of the terrace prior to the road being built up. This is the most plausible scenario since the terrace-edge road obviously was built up with an additional 30-40-cm-thick cap of artificial fill placed directly on top of the historic debris. Notably, there is evidence of burning (i.e., charcoal and burned sediment) throughout Feature 1 and in the overlying and underlying sediments (i.e., 0-77 $\mathrm{cm}$ below the surface in Backhoe Trench 1). Similar evidence of burning was noted from 0-72 $\mathrm{cm}$ below the surface in Backhoe Trench 4, located ca. $120 \mathrm{~m}$ east of Feature 1. This widespread burning probably resulted from clearing of vegetation and burning of brush piles. Thus, the shell artifacts were collected.

\section{CERAMICS}

One hundred sixty sherds representing 96 vessels were recovered by surface collection unit and bladed subsurface in the vicinity of Feature 1. Wares are 16 coarse-paste earthenware, 5 yellowware, 4 refined-paste earthenware, 84 white earthenware, 22 semivitreous whiteware, 26 vitreous whiteware, 1 porcelain, and 2 stoneware sherds. In addition, a ceramic pipe fragment was recovered (see Other Artifacts).

Seven coarse-paste earthenware vessels lack decoration other than a colorless lead glaze. Two red and one buff (with gray core) vessels have no glaze. One orange vessel has a colorless leadglazed interior and exterior, and two others have colorless lead-glazed interiors and dry exteriors. One vessel has a buff interior and gray exterior, both of which have colorless lead glazes. Thinwalled $(2-4 \mathrm{~mm})$ vessels may represent undecorated portions of Galera ware vessels, and some of the thick-walled vessels may represent similar Red Brown ware bowls (see below).

Four coarse-paste earthenware vessels are decorated. One vessel is orange with white dots on a brown ground. The thin wall of this vessel, its brown and cream decoration in the form of bands and raised dots, and the white and brown mineral temper indicate that this vessel is polychrome- 
TABLE 23

SURFACE ARTIFACTS OBSERVED AT 41HG158

\begin{tabular}{|c|c|c|c|c|c|}
\hline Surface Collection Unit & Material Class & \multicolumn{4}{|l|}{ No. and Type of Artifact } \\
\hline Unit $1(\mathrm{n}=52)$ & $\begin{array}{l}\text { Ceramic } \\
\text { Glass } \\
\text { Metal } \\
\text { Brick }\end{array}$ & \multicolumn{4}{|c|}{$\begin{array}{l}15 \text { undecorated whiteware sherds } \\
1 \text { undecorated semivitreous sherd } \\
1 \text { stoneware sherd with Albany and Bristol glazes } \\
11 \text { aqua container fragments } \\
8 \text { clear container fragments ( } 1 \text { slightly solarized) } \\
1 \text { clear continuous-thread jar neck fragment } \\
6 \text { brown container fragments } \\
1 \text { white container fragment } \\
1 \text { clear flat glass (i.e., window) fragment } \\
1 \text { ferrous spike head } \\
3 \text { ferrous sheet metal fragments } \\
1 \text { crown cap (marked "Hecho en Mexico")* } \\
2 \text { yellow fragments }\end{array}$} \\
\hline Unit $2(n=53)$ & $\begin{array}{l}\text { Ceramic } \\
\text { Glass } \\
\text { Brick } \\
\text { Bone }\end{array}$ & \multicolumn{3}{|l|}{$\begin{array}{l}13 \text { undecorated whiteware sherds } \\
7 \text { clear container fragments } \\
4 \text { aqua container fragments } \\
2 \text { cobalt blue container fragments } \\
13 \text { yellow fragments } \\
13 \text { orange fragments } \\
1 \text { bovid tooth }\end{array}$} & \\
\hline Unit $3(n=122)$ & $\begin{array}{l}\text { Ceramic } \\
\text { Glass } \\
\text { Metal } \\
\text { Brick } \\
\text { Bone } \\
\text { Wood }\end{array}$ & \multicolumn{4}{|c|}{$\begin{array}{l}27 \text { undecorated whiteware sherds } \\
14 \text { clear container fragments } \\
1 \text { clear lamp chimney fragment } \\
1 \text { clear threaded bottle neck fragment } \\
1 \text { clear round bottle base with embossed stippled design } \\
7 \text { aqua container fragments } \\
2 \text { white container fragments } \\
2 \text { olive green container fragments } \\
1 \text { brown container fragment } \\
1 \text { crown cap* } \\
1 \text { aluminum irrigation tube fragment* } \\
1 \text { ferrous bolt with nut } \\
1 \text { wire nail } \\
31 \text { yellow fragments } \\
28 \text { orange fragments } \\
2 \text { unidentified fragments } \\
1 \text { unidentified fragment* }\end{array}$} \\
\hline Unit $4(\mathrm{n}=70)$ & $\begin{array}{l}\text { Ceramic } \\
\text { Glass } \\
\text { Metal } \\
\text { Brick } \\
\text { Bone }\end{array}$ & \multicolumn{4}{|l|}{$\begin{array}{l}6 \text { undecorated whiteware sherds } \\
2 \text { aqua container fragments } \\
1 \text { clear container fragment } \\
1 \text { white container fragment } \\
1 \text { cuprous wire fragment } \\
20 \text { yellow fragments } \\
37 \text { orange fragments } \\
2 \text { unidentified fragments }\end{array}$} \\
\hline
\end{tabular}




\begin{tabular}{|c|c|c|}
\hline \multicolumn{3}{|l|}{ Table 23 , continued } \\
\hline Surface Collection Unit & Material Class & No. and Type of Artifact \\
\hline Unit $5(n=24)$ & $\begin{array}{l}\text { Ceramic } \\
\text { Glass } \\
\text { Brick } \\
\text { Other }\end{array}$ & $\begin{array}{l}3 \text { undecorated whiteware sherds } \\
3 \text { aqua container fragments } \\
2 \text { brown container fragments } \\
1 \text { clear bottle neck fragment, crown finish } \\
1 \text { clear bottle neck fragment, threaded } \\
6 \text { yellow fragments } \\
7 \text { orange fragments } \\
1 \text { mortar fragment }\end{array}$ \\
\hline Unit $6(n=30)$ & $\begin{array}{l}\text { Ceramic } \\
\text { Glass } \\
\text { Brick }\end{array}$ & $\begin{array}{l}3 \text { undecorated whiteware sherds } \\
1 \text { undecorated yellowware sherd } \\
6 \text { clear container fragments } \\
1 \text { clear round bottle base with embossed "7" } \\
1 \text { clear bottle neck fragment, threaded } \\
1 \text { aqua container fragment } \\
1 \text { brown container fragment } \\
1 \text { white ribbed container rim fragment } \\
3 \text { yellow fragments } \\
12 \text { orange fragments }\end{array}$ \\
\hline Unit $7(\mathrm{n}=51)$ & $\begin{array}{l}\text { Ceramic } \\
\text { Glass } \\
\text { Brick }\end{array}$ & $\begin{array}{l}14 \text { undecorated whiteware sherds } \\
4 \text { brown container fragments } \\
3 \text { clear container fragments } \\
3 \text { aqua container fragments } \\
2 \text { white fluted container fragments } \\
1 \text { white container fragment } \\
7 \text { yellow fragments } \\
17 \text { orange fragments }\end{array}$ \\
\hline Unit $8(n=15)$ & $\begin{array}{l}\text { Ceramic } \\
\text { Glass } \\
\text { Brick }\end{array}$ & $\begin{array}{l}2 \text { undecorated whiteware sherds } \\
2 \text { aqua container fragments } \\
1 \text { clear container fragment } \\
1 \text { brown container fragment } \\
1 \text { olive green container fragment } \\
1 \text { white bowl rim fragment with embossed crosshatched design } \\
3 \text { yellow fragments } \\
4 \text { orange fragments }\end{array}$ \\
\hline Unit $9(\mathrm{n}=5)$ & $\begin{array}{l}\text { Ceramic } \\
\text { Glass }\end{array}$ & $\begin{array}{l}3 \text { undecorated whiteware sherds } \\
1 \text { clear container fragment } \\
1 \text { brown container fragment }\end{array}$ \\
\hline
\end{tabular}

decorated Galera ware, commonly small jars and pots moldmade in western Mexico and found in Texas on sites dating from 1750 until the early 1800 s, although similar wares currently are made in Jalisco (Dial 1992:34; Fox 1986:111). Another vessel has a red to gray paste with brown and white bands (Figure 52a), and an orange vessel has brown bands and white and green wash (Figure $52 b$ ). The fourth vessel is orange with a brown band and yellow dots (Figure 52c). These vessels have thick walls, variable-color pastes, and probably represent cooking and storage ollas. 


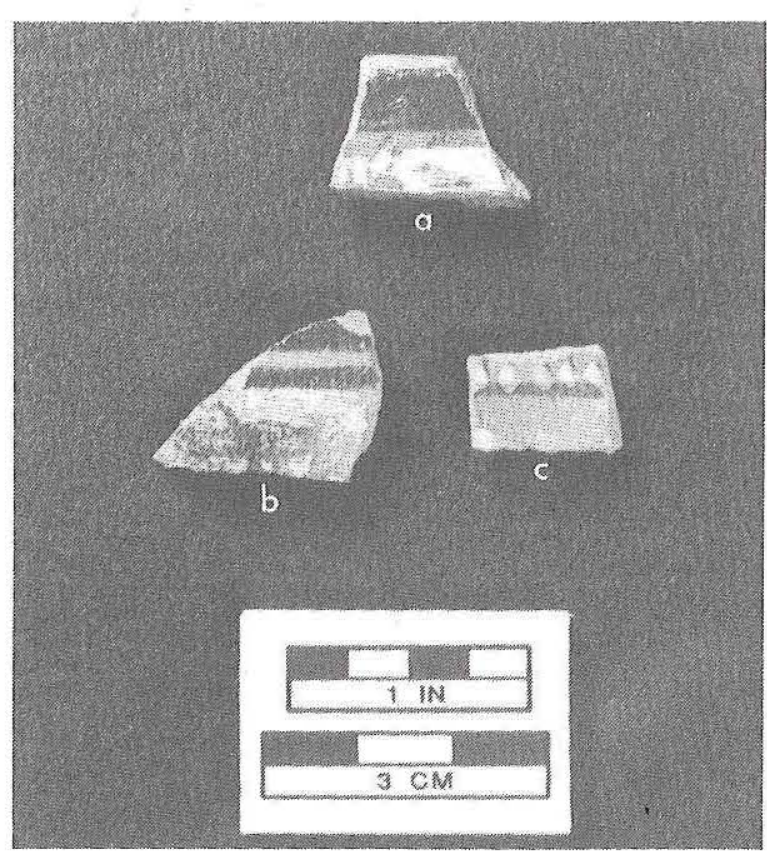

Figure 52. Decorated coarse-paste earthenwares, 41HG158. (a) Vessel rim with red to gray paste and brown and white bands, Red Brown ware(?); (b) orange vessel with brown bands and white and green wash, Red Brown ware(?); (c) orange vessel with yellow dots and brown band, Red Brown ware(?).

They are similar to Red Brown ware except in the thinness of the glaze and in vessel form (Dial 1992:34).

Refined redware vessels with cream-colored clay glazes are one undecorated and one mug or cup with an orange band. Yellowwares consist of two vessels with yellow-tinted lead glaze, one a large footed bowl. Banded vessels are a bowl with a dark brown band and white ground on the exterior and a vessel with medium brown bands. Banding on yellowwares postdates its use on whitewares. The fifth yellowware has a mottled brown flint enamel (Rockingham-like) glaze. Flint enamel dates from about 1844 to the present (Ketchum 1987:18).

Two buff stonewares have colorless lead glazes. A third buff stoneware vessel has an Albany-glazed interior and a Bristol-glazed exterior. Lebo (1991:161) dates this type in the north-central Texas area to 1890-1915.

Whiteware decoration types are annular, underglaze and overglaze hand painted, sponge stamped, sponge spattered, transfer printed, decal, molded, molded and underglaze hand painted, and overall glaze (Table 24).

Three vessels have annular decoration. Two are banded, and one has mocha decoration. The banded vessels have dark brown stripes or bands and blue or yellow grounds. The vessel with narrow brown stripes (Figure 53a) has a medium, rather than earthen, blue ground. The narrow stripes are reported to represent early nineteenthcentury decoration and the bright color late nineteenth- or early twentieth-century decoration (Majewski and O'Brien 1987:163; Miller 1991:6). This combination of decoration attributes is best dated to the late nineteenth/early twentieth century. The vessel with a yellow and earthen blue ground (Figure $53 b$ ) has a fragment of a curved dark brown motif that could represent an earthworm or dot pattern, although there is no evidence of the swirl or marbleized treatment usually associated with these patterns. The 'mocha-decorated vessel (Figure 53c) has the earthen blue and browns characteristic of its 1795-1835 period of popularity on American sites, although mocha mugs continued to be produced for English taverns until the 1930s (Miller 1991:6).

Three vessels have underglaze hand-painted decoration. The brown rim-banded vessel is a semivitreous whiteware saucer. A white earthenware saucer has a single wide brown band encircling the well. Two vessels with black overglaze hand-painted decoration are a vitreous whiteware saucer with two thin bands encircling the well and a vessel with an open grid pattern.

Three vessels are sponge stamped. Two have a matching dark red floral pattern (Figure $53 d, e$ ) that apparently was very widespread; similar examples are illustrated in Price (1979:Plate 7, top left) and Majewski and O'Brien (1987:Figure 5e). The third vessel has a dark red floral motif resembling a cut pie with light green single-branch leaves (Figure 53f). The floral motif appears stenciled, but the edges are slightly uneven as is characteristic of sponge stamping. The leaves are fuzzy and definitely were not stenciled. Although the decoration technique is not certain, the colors are characteristic of the midcentury 1840-1860 time period. The sponge-stamped technique dates from 1845 to the Civil War and later (Majewski and O'Brien 1987:161-163).

One vessel is sponge spattered (Figure $53 g$ ). The powdered color was applied in two stages, both underglaze. The blurring of the blue spatters 
TABLE 24

WHITEWARE CERAMIC DECORATION TYPES, 41 HG158

\begin{tabular}{|c|c|c|c|}
\hline Decoration Type & Pattern & Color & Vessel Form \\
\hline Annular & $\begin{array}{l}\text { banded } \\
\text { mocha }\end{array}$ & $\begin{array}{l}\text { brown and blue } \\
\text { brown, yellow, blue } \\
\text { brown, tan, blue }\end{array}$ & $\begin{array}{l}\text { unknown } \\
\text { unknown } \\
\text { unknown }\end{array}$ \\
\hline $\begin{array}{l}\text { Underglaze } \\
\text { hand painted }\end{array}$ & $\begin{array}{l}\text { unknown } \\
\text { rim band } \\
\text { banded } \\
\text { grid }\end{array}$ & $\begin{array}{l}\text { red and yellow } \\
\text { brown } \\
\text { brown } \\
\text { black } \\
\text { black }\end{array}$ & $\begin{array}{l}\text { unknown } \\
\text { saucer } \\
\text { saucer } \\
\text { saucer } \\
\text { unknown }\end{array}$ \\
\hline Sponge stamped & floral & red & 1 cup, 1 unknown \\
\hline Sponge stamped? & floral & red and green & plate or saucer \\
\hline Sponge spattered & - & blue and green & unknown \\
\hline Transfer printed & $\begin{array}{l}\text { unidentified } \\
\text { floral } \\
\text { Phoenix } \\
\text { Christmas tree }\end{array}$ & $\begin{array}{l}\text { blue } \\
\text { purple } \\
\text { green } \\
\text { blue } \\
\text { red }\end{array}$ & $\begin{array}{l}\text { unknown } \\
\text { plate or saucer } \\
\text { unknown } \\
\text { saucer } \\
\text { cup }\end{array}$ \\
\hline Flow & $\begin{array}{l}\text { unidentified } \\
\text { unknown } \\
\text { scroll }\end{array}$ & $\begin{array}{l}\text { blue } \\
\text { blue } \\
\text { blue }\end{array}$ & $\begin{array}{l}1 \text { bowl?, } 1 \text { cup } \\
\text { plate or platter } \\
\text { saucer }\end{array}$ \\
\hline Decal & $\begin{array}{l}\text { shamrock } \\
\text { floral } \\
\text { floral/scroll } \\
\text { tulip } \\
\text { floral } \\
\text { geometric } \\
\text { unknown } \\
\text { floral }\end{array}$ & $\begin{array}{l}\text { green, black, pink } \\
\text { orange, green, yellow } \\
\text { pink and green } \\
\text { black, blue, orange, pink, green } \\
\text { orange and green } \\
\text { pink, green, orange } \\
\text { black, blue, orange, green } \\
\text { blue and black } \\
\text { red }\end{array}$ & $\begin{array}{l}\text { saucer or plate } \\
\text { plate } \\
\text { saucer or bowl } \\
\text { cup } \\
\text { saucer } \\
\text { cup? } \\
\text { unknown } \\
\text { unknown } \\
\text { plate? }\end{array}$ \\
\hline Molded & $\begin{array}{l}\text { scroll } \\
\text { scallops below rim } \\
\text { lines perpendicular to rim } \\
\text { beaded and lines } \\
\text { lines perpendicular to rim } \\
\text { and wavy channel } \\
\text { scroll }\end{array}$ & $\left.\begin{array}{l}- \\
- \\
-\end{array}\right)$ & $\begin{array}{l}\text { saucer } \\
\text { saucer } \\
\text { saucer } \\
\text { saucer } \\
\text { bowl or saucer } \\
\text { unknown }\end{array}$ \\
\hline $\begin{array}{l}\text { Molded and } \\
\text { underglaze } \\
\text { hand painted }\end{array}$ & $\begin{array}{l}\text { shell } \\
\text { lines and dots }\end{array}$ & $\begin{array}{l}\text { pink } \\
\text { blue and pink } \\
\text { blue }\end{array}$ & $\begin{array}{l}\text { saucer? } \\
\text { cup } \\
\text { saucer }\end{array}$ \\
\hline Overall glaze & - & $\begin{array}{l}\text { cream } \\
\text { aqua }\end{array}$ & $\begin{array}{l}\text { plate? } \\
\text { plate }\end{array}$ \\
\hline
\end{tabular}




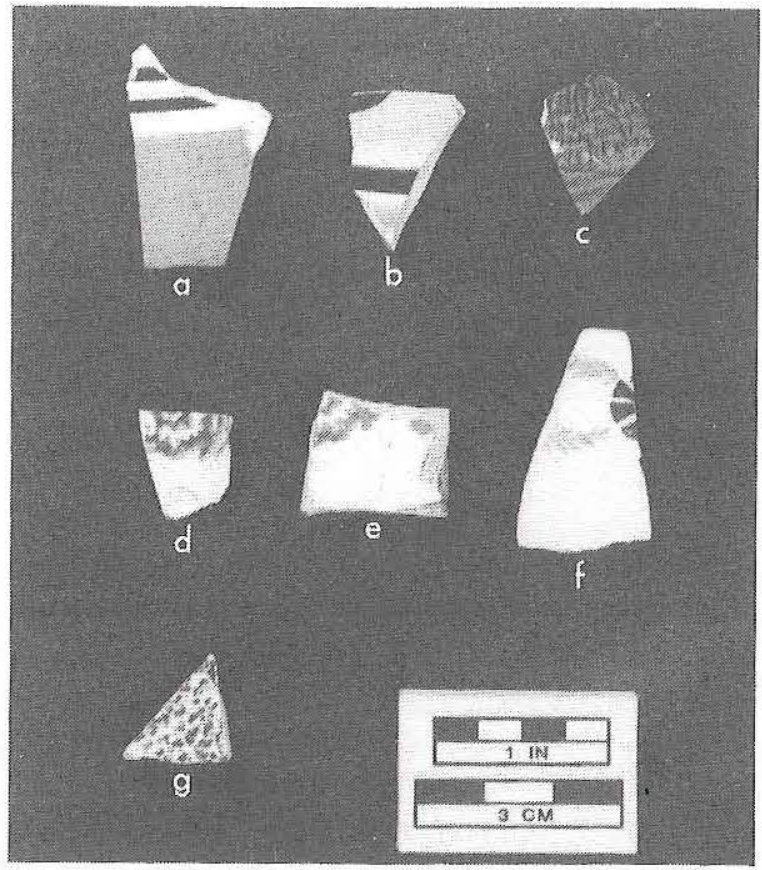

Figure 53. Whitewares with annular and sponge decoration, 41HG158. (a) Banded bowl with brown stripes and medium blue ground; $(b)$ banded vessel with brown band and partial motif and yellow and earthen blue grounds; $(c)$ mocha-decorated vessel with dark brown on tan and earthen blue grounds; $(d-e)$ red floral spongestamped vessels; $(f)$ sponge-stamped/stenciled plate rim with red and green floral pattern; $(g)$ sponge-spattered bowl with blue and green decoration.

and distinctness of the green indicate that the blue was applied first. Spatter decoration appears on a wide range of tableware, teaware, and toiletware forms and was produced in great quantities by British potteries throughout the nineteenth century, primarily for export, and in the United States after about 1850 (Majewski and O'Brien 1987:161).

Nine vessels are transfer printed. Two of these are probable pre- 1845 types. One is a light blue vessel with an unidentified pattern and stippling characteristic of the first half of the nineteenth century. The other is a purple plate or saucer with an unidentified closed-design pattern and stippling (Figure 54a). Both of these wares have a crazed colorless lead glaze.

Four of the transfer-printed vessels have flow blue decoration. The rim design of the possible bowl has flowed so extensively that the pattern is unidentifiable. The plate or platter pattern is unidentifiable, consisting of curved and straight (?) linear element fragments, but the design is more

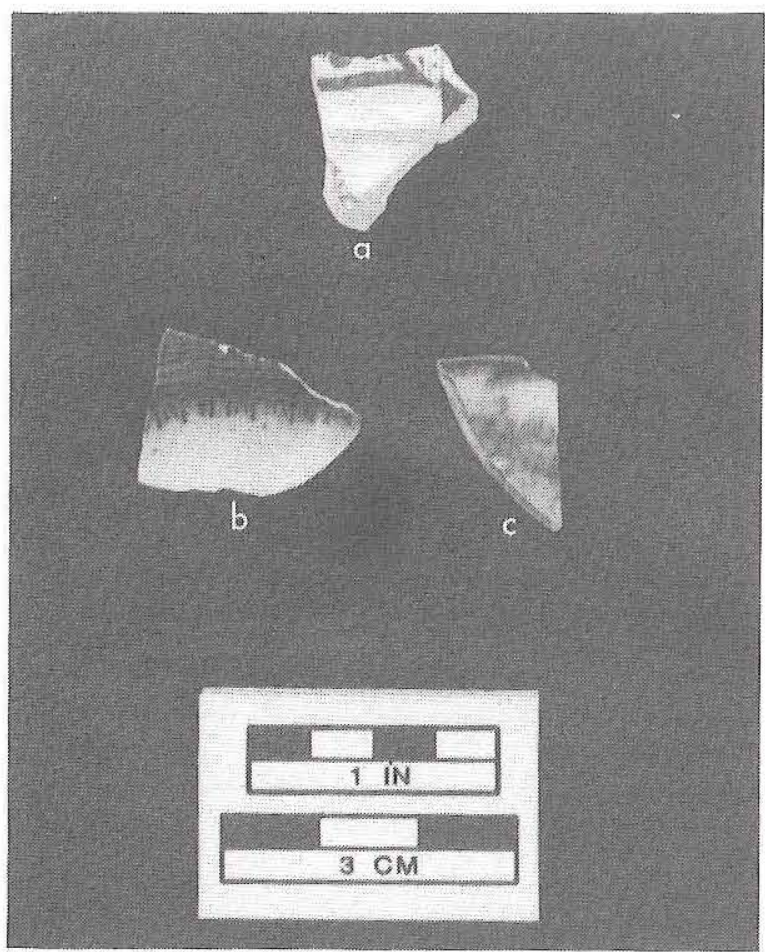

Figure 54. Transfer-printed whitewares, 41HG158. (a) Purple plate or saucer; $(b)$ flow blue cup body sherd; (c) semivitreous saucer with flow blue decoration.

open than that on the other three vessels and may be late nineteenth century in date. The cup fragment (Figure $54 b$ ) has a distinctive lower border design. The flow blue saucer (Figure 54c) has a semivitreous body. Flow blue decoration dates from 1835-1840 to 1910 (Williams 1981:ii), although it probably was not common in Texas until the mid 1840s.

A dark green transfer-printed vessel (Figure $55 a-b)$ has the stippling and closed design characteristic of the early nineteenth century, but the glaze is not crazed; this vessel probably dates to the twentieth century. The blue Phoenix pattern occurs on a vitreous whiteware saucer (Figure $55 c-d$ ). This pattern is identical to that from the 1846-1867 and later occupation of Brazos Santiago (Banks 1983:Figure 31B). This pattern, known as the Flying Phoenix, Flying Turkey or Ho-o, has been used on Japanese export porcelain since at least the last quarter of the nineteenth century and is still manufactured today (Banks 1983:149). A probable twentieth-century transferprinted vessel is represented by a red Christmas tree pattern on a white earthenware cup (Figure $55 e)$. 


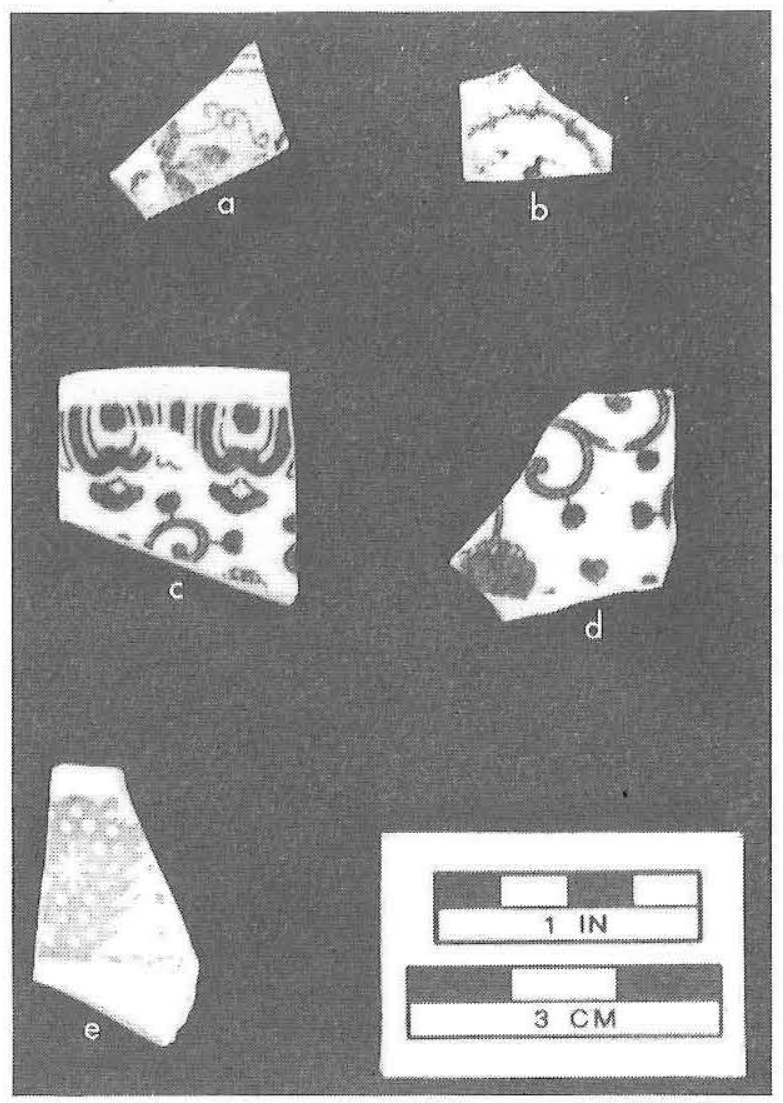

Figure 55. Transfer-printed whitewares, 41HG158. $(a-b)$ Semivitreous vessel with dark green transfer print; $(c-d)$ vitreous saucer with blue Phoenix pattern; (e) cup with red Christmas tree pattern.

Nine vessels have overglaze decal decoration. Eight of these have polychrome decoration, and one has monochrome. The orange, green, and yellow plate has a green-printed Owen China Co. mark which is discussed below. The pink and green floral decal occurs on a semivitreous whiteware saucer or bowl. The shamrock pattern occurs on an unknown vessel (Figure 56a). The polychrome floral and floral/scroll patterns (Figure $56 b$ ) occur on vitreous whiteware cups. The orange and green tulip pattern (Figure 56c) occurs on a white hardpaste porcelain. The unknown decal occurs on a semivitreous whiteware. With the exception of one of the floral decals, the shamrock decal, and the unknown decal, which are in good condition, the floral decals are eroded and probably date to the first quarter of the twentieth century, when decals tended to be subject to erosion (Majewski and O'Brien 1987:146-147; Moir 1987a:103-106). The other three decals may date to the second

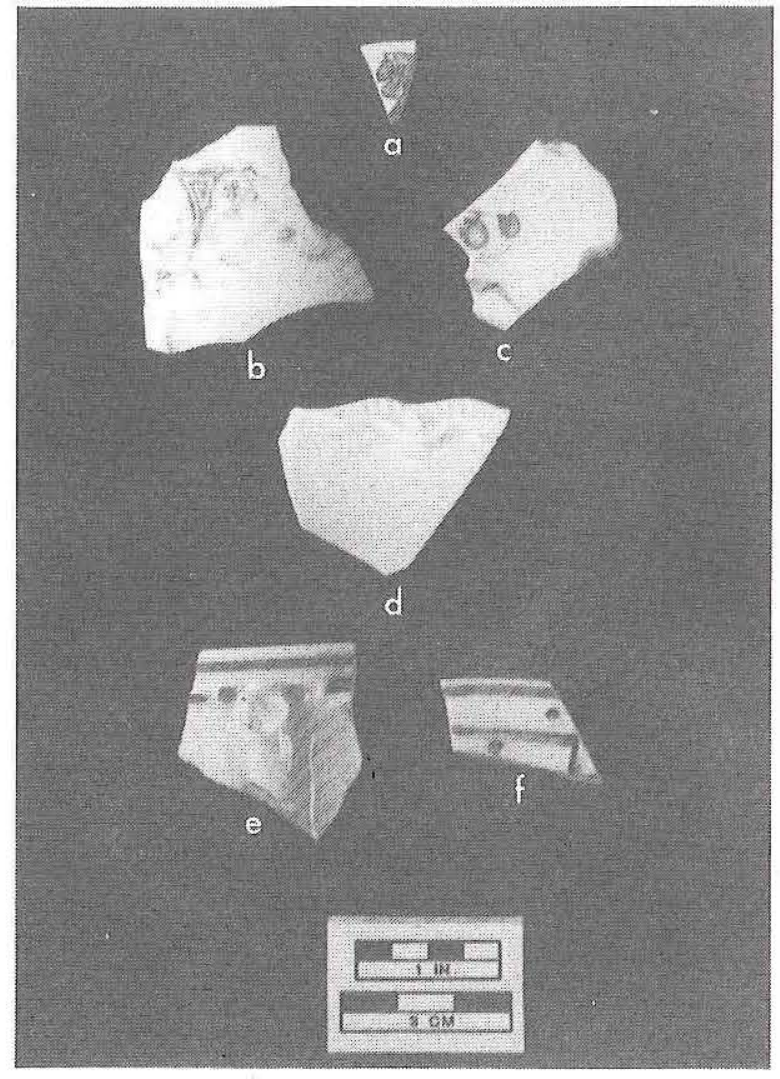

Figure 56. Whitewares with decal and molded/painted decoration, 41HG158. (a) Vessel with green and black shamrock decal; $(b)$ vitreous cup rim with polychrome floral/scroll decal; $(c)$ porcelain saucer with polychrome tulip decal; $(d)$ vessel rim with molded lines perpendicular to rim and wavy channel; $(e)$ vitreous handled cup with molded and blue and pink line and dot decoration; (f) vitreous saucer with molded and blue line and dot decoration.

quarter of the twentieth century. The eighth overglaze decal decoration consists of the remnants of a red floral design on a vitreous plate. This pattern resembles Japanese imports dating to the second quarter of the twentieth century.

Six vessels have molded decoration. The scroll pattern saucer is similar to an example from the 1846-1867 United States occupation of Brazos Santiago at the mouth of the Rio Grande (Banks 1983:41, Figure 22B). The vessel with molded lines perpendicular to the rim and wavy channel (Figure $56 d$ ) may date to the nineteenth century. The beaded and lines pattern occurs on a semivitreous whiteware. Another scroll pattern occurs on a semivitreous whiteware vessel of unknown form. These vessels probably date to the second 
half of the nineteenth century or later.

Three vessels have molded and underglaze hand-painted decoration. The pink shell pattern occurs on a vitreous saucer (?). The matching line and dot pattern occurs on a vitreous whiteware handled cup and saucer (Figure 56e-f). These vessels probably date to the twentieth century.

Two vessels have overall colored glazes. One is a cream-colored glaze, and the other is a Fiesta-like aqua glaze. The aqua glaze, which is lighter than the Homer Laughlin China Co. true Fiesta glaze, occurs on a white earthenware saucer fragment with a partial maker's mark (described below).

Thirty-seven vessels are undecorated refined whitewares (Table 25). Six of these have partial maker's marks (described below).

\begin{tabular}{|c|l|l|}
\hline \multicolumn{3}{|c|}{ TABLE 25 } \\
41HG158 \\
\hline \multicolumn{3}{|c|}{ UNDECORATED WHITEWARE VESSELS, } \\
\hline No. of Vessels & Ware & Vessel Form \\
\hline 4 & earthen & cup \\
1 & semivitreous & cup \\
3 & vitreous & cup \\
1 & earthen & bowl or saucer \\
10 & earthen & saucer \\
3 & semivitreous & saucer \\
3 & vitreous & saucer \\
10 & earthen & plate \\
2 & semivitreous & plate \\
\hline
\end{tabular}

Eight diagnostic maker's marks are represented in the 41 HG158 ceramic assemblage. A mark on the floral decal-decorated plate sherd (Figure 57a) is "GOLD MEDAL" over "ST. LOUIS" over "OWEN CHINA" over " $826 \mathrm{~A}$." It is the mark of the Edward J. Owen China Co. of Minerva, Ohio, which operated from 1902 to ca. 1930 (DeBolt 1988:58) or 1902-1932. Dinnerware was one of their products, and as early as 1904 the company won a gold medal for best domestic semiporcelain at the Louisiana Exposition in St. Louis (Lehner 1988:333). DeBolt describes this as a 1920s mark, and the printed " 26 " is consistent with this dating.

A mark on the aqua-glazed saucer sherd (Figure $57 b$ ) is very incomplete but includes a partial depiction of a vase and is identified as a mark used by the Edwin M. Knowles China Co. of East Liverpool, Ohio, on semivitreous and vitreous

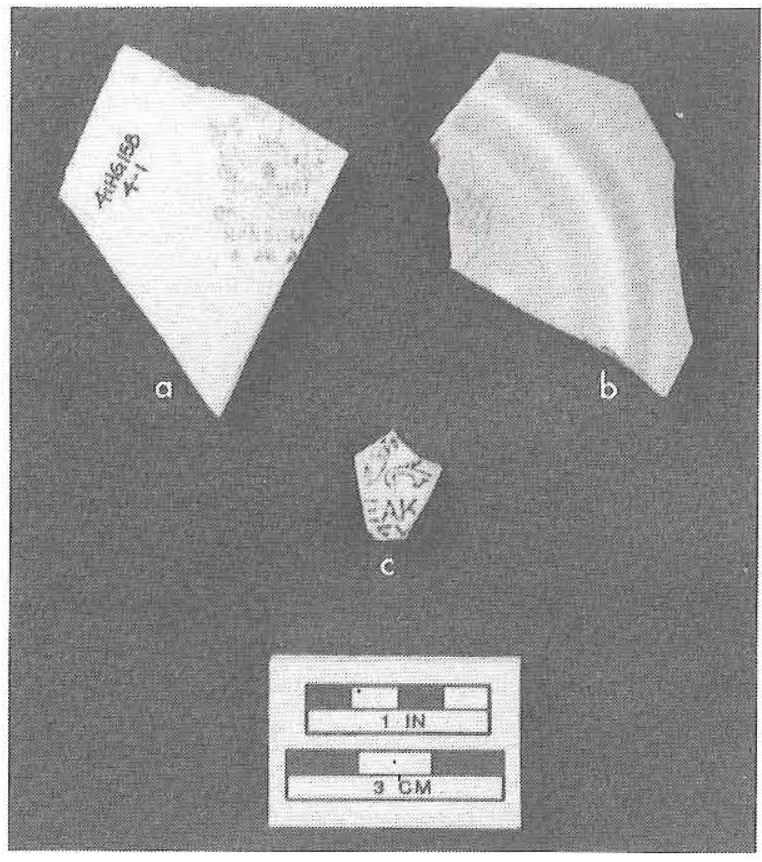

Figure 57. Whitewares with maker's marks, 41HG158. (a) Polychrome floral decal-decorated plate base with green printed Edward J. Owen China Co. mark; (b) saucer with overall aqua glaze and black(?) printed Edwin M. Knowles China Co. vase mark; $(c)$ undecorated plate or saucer with black printed Meakin Royal Arms mark.

wares from 1900-1948 (Gates and Ormerod 1982:99-100). This particular specimen lacks the company name and the year date below the vase. Lehner (1988:237) notes that Knowles patented a vase mark labeled "VITREOUS (no. 2)" in 1920. The crosshatching on the body of the vase was more widely spaced in the 1940s than in earlier versions of this mark, so the 41 HG158 specimen probably dates to the 1901-1929 period (DeBolt 1988:39-40).

The partial mark on an undecorated whiteware plate or saucer sherd (Figure 57c) is ". . NSE" along the edge of a shield design over ". . EAK ..." over "... EY. . . ." This mark is the lower right portion of a Meakin, Hanley, mark with the Royal Coat of Arms and a shield labeled "HONI SOIT QUI MAL Y PENSE." Several Meakins had potteries in Hanley, including Charles Meakin (1883-1889), Harry Meakin (ca. 1870), and J. \& G. Meakin (1851-present). Since the latter has the longest production period and featured the Royal Arms in many of its marks (Godden 1964: $426-427)$, it is the most likely maker of this 
vessel.

The five other marks are all on whiteware sherds that have no apparent decoration. One of these is an unidentifiable green printed incomplete mark on a plate base fragment. A fragmentary mark is a black printed "... OCIÉT . .." and represents the upper portion of a Société Céramique, Maastricht, Holland, mark recorded on porcelain dating 1887 and later (Kovel and Kovel 1986:56M). The identification is based on the first accent mark in Société, which in other illustrated company name marks (e.g., Kovel and Kovel 1986:103B, 211B, 211N) is not spelled out or does not include the accent marks. An additional letter fragment above the mark is illegible and is not included in published illustrations of this mark.

One mark is a tiny fragment from a thin $(0.09$ inch-thick) white earthenware. The green printed mark represents the upper portion of the Homer Laughlin China Co. monogram "HL." Homer Laughlin operated the Ohio Valley Pottery alone beginning in 1877 and incorporated his firm in 1896. The company produced semivitreous dinner, hotel, and toilet wares during the World War I era and popular dinner, oven, and kitchen wares during the 1930-1960 period. The company today retains its position as one of the largest potteries in the world. The small "HL" monogram occurs on different whiteware pattern name marks dating from 1900-1970 (DeBolt 1988:45; Gates and Ormerod 1982:128, 136-145; Lehner 1988:249250). DeBolt (1988:88) dates examples of the monogram in which the horizontal line connecting the $\mathrm{H}$ and $\mathrm{L}$ does not extend outside of the $\mathrm{H}$, as in this example, to the post-1920 period. Similar illustrated mark Nos. 50-55 (Lehner 1988:249) were used during World War II and into the early 1950s for a fine thin semiporcelain dinnerware named Eggshell for its thinness and composition (Lehner 1988:247). The mark fragment's thinness may indicate it is from a vessel of this ware.

The other two marks are fragments of Royal Coat of Arms marks. One is a white earthenware plate fragment with the left side showing a fullface lion, the "DIEU ET" portion of the banner labeled "DIEU ET MON DROIT," and "WARRANT ..." in an arch left of the lion. The other is a semivitreous whiteware plate fragment with the upper right portion containing the unicorn head. The British Royal Arms and copies occur in printed marks of many nineteenth- and twentieth- century British manufacturers and foreign firms (Godden 1964:552).

No crossmends were made between the collection units to demonstrate postdepositional horizontal movement of artifacts, although the plowed-field context of the site suggests that movement has been extensive. Distributions of decoration types were examined for spatiotemporal clusters. Pre-1845/1850 mocha and transferprinted types occur in Collection Units 1 and 6, which are $200 \mathrm{~m}$ apart. Midcentury flow blue, sponge-stamped, and molded scroll types occur in Units 2, 3, 4, 5, and 7, which span over $200 \mathrm{~m}$. The turn-of-the-century Albany/Bristol stoneware occurs in Unit 3, on the east end of the site. Floral decals and the molded bead and line saucer dating to the first quarter of the twentieth century occur in Units 1,2,3,4, and 9, from one end of the site to the other. The Knowles mark dating from 19011929 occurs in Unit 1, and the Owen mark dating to 1926 occurs in Unit 4. Late nineteenth/ twentieth-century banded and sponge-spattered types and Meakin and Société Céramique marks occur in Units 2, 3, and 4 on the east end of the site. Transfer-printed, decal, and molded and painted decoration types and the Homer Laughlin mark dating to the second quarter of the twentieth century occur in Units $2,3,4,5$, and 7 . These distributions indicate that most of the temporally diagnostic decoration types occur on the east half of the site, Units 2-4 were occupied for at least a century beginning in about 1845 , and Unit 1 , with evidence of pre-1845 occupation, also was occupied during the first quarter of the twentieth century. Unit 6 , with a probable pre-1845 sherd, has no other diagnostic sherds to indicate a concentration of pre-Mexican War trash. Feature 1 contains nondiagnostic undecorated whiteware sherds. There is no distributional evidence for occupations of limited time span occurring at 41HG158.

The ceramics from this site range from preMexican War to mid-twentieth-century types. Decoration types reflecting a pre-Mexican war occupation are the closed-design, stippled transfer-printed types and the annular types, particularly the mocha decoration. Midcentury (1845-1865) occupation is indicated by spongestamped, flow blue, and molded scroll decoration types. The Albany and Bristol glaze stoneware reflects turn-of-the-century occupation. Late 
nineteenth/twentieth-century ceramics are flint enamel glaze, banded, sponge-spattered decoration types and the Meakin and Société Céramique marks. Ceramics dating to the first quarter of the twentieth century are floral decal and bead and line decoration types and the Knowles mark. Ceramics indicating occupation during the second quarter of the twentieth century are open-design transferprinted, noneroded and monochrome decals, and molded and painted decoration types and the Owen and Homer Laughlin marks. The ceramic assemblage reflects a long-term, probably continuous occupation of 41HG158 from preMexican War to World War II times.

\section{GLASS}

Eighty-six fragments of container or tableware glass were collected from this site (Table 26). None of the fragments fluoresce under shortwave ultraviolet light.

At least 34 vessels are represented by the collected glass. One olive green wine or champagne bottle and one dark green cylindrical bottle, possibly a wine or champagne bottle, are present.

The count of eight aqua bottles was determined from bases. These consist of three medicine bottles, one cylindrical beverage (probably soda pop) bottle, one cylindrical beverage bottle, two cylindrical bottles, and one cylindrical (possibly wine or champagne) bottle. The medicine bottle ring or oil and unknown finishes and the doublebeaded and crown beverage bottle finishes may represent the same vessels as the basal fragments. A Coca Cola bottle body fragment may match with the possible soda pop bottle base.

Two emerald green cylindrical bottles were collected, and one of these is a beverage bottle, probably soda pop. The two solar-purpled vessels are a cylindrical bottle and an unknown container or tableware vessel.

At least 10 colorless containers were collected. Eight are represented by bases. These consist of two medicine bottles, three cylindrical beverage bottles, two bottles, and one possible drinking glass. One octagonal bottle is represented by a body fragment. At least one additional medicine bottle is represented by one of the medicine bottle finishes, of which there are four. Two medicine bottle necks, another bottle neck, and a bottle or jar threaded finish also are present.
The brown containers consist of two beer bottles, one beverage bottle, and one bottle. One cobalt blue jar and one cobalt blue bottle with tan enamel paint also are present. White glass tablewares consist of two cups, one plate, and two plates or saucers. Additional vessels observed but not collected consist of one colorless cylindrical beverage bottle, one colorless beverage bottle, one colorless cylindrical bottle, two colorless bottles with threaded finishes, and two white containers.

The olive green cylindrical wine or champagne bottle base fragment has the lower portion of a high pushup but is too fragmentary to show the pushup profile. The base was handblown in the first half of the nineteenth century. Two similar bottle bases with pushups in dark green and aqua glass also may be handblown and predate the Civil War.

The medicine bottles reflect 1860-1920 manufacture. An aqua medicine bottle panel fragment marked ". . . R. J . . ." may be from a product named "DR. J. _.." Examples include Dr. J. Bovee Dod's Imperial Wine 1858 (Wilson 1981:133) or Dr. J. B. Marchisi's Celebrated Uterine Catholicon, 1858-1860 (Wilson 1981:138). An aqua medicine bottle base with post base seam has flat chamfered corners typical of this time period (Figure 58a). The aqua medicine bottle finish with ring or oil finish (Fike 1987:Figure 2.11) has no seams, indicating that it has been fire polished or made with a finish-forming tool.

The aqua cylindrical beverage bottle base marked "ROOT" was made by the Root Glass Co. of Terre Haute, Indiana, from 1901-1932 (Toulouse 1971:445). The light aqua bottle base is marked "7 OI [inside diamond] 4/1," indicating manufacture by the Owens Illinois Glass Co./ Owens-Illinois Inc., Toledo, Ohio, between 1929 and 1954. The ".7" indicates manufacture in the Alton, Illinois, plant, and the "4" indicates manufacture in 1934, 1944, or 1954. The "1" describes the mold used (Toulouse 1971:395, 403). The aqua bottle base marked ". . ADERO S.A." may be from a San Antonio soda pop bottler. The aqua double bead (Wilson 1981:111f) or double ring (Fike 1987:Figure 2.1) finish (Figure 58b) has side seams extending over the top of the finish and a seam at the base of the finish, indicating automatic bottle machine manufacture (Fike 1987:11; Miller and Sullivan 1991:109).

The emerald green cylindrical bottle base with 


\begin{tabular}{|c|c|c|}
\hline \multicolumn{3}{|c|}{$\begin{array}{c}\text { TABLE } 26 \\
\text { COLLECTED GLASS, } 41 \mathrm{HG} 158\end{array}$} \\
\hline Provenience & Color and Type & No. and Description of Sherd \\
\hline Collection Unit $1 *$ & $\begin{array}{l}\text { aqua cylindrical bottle, probably } \\
\text { soda pop }\end{array}$ & $\begin{array}{l}1 \text { heel sherd with cup base seam; marked with ". . . } \\
\text { ADERO S.A." }\end{array}$ \\
\hline Collection Unit $1^{*}$ & $\begin{array}{l}\text { emerald green cylindrical beverage } \\
\text { bottle }\end{array}$ & $\begin{array}{l}1 \text { stippled base sherd; marked with "CONTENT . . ." } \\
\text { over "8LGWI" over " } 245 \text { " }\end{array}$ \\
\hline Collection Unit $1 *$ & colorless cylindrical beverage bottle & $\begin{array}{l}1 \text { base sherd with post base seam, valve mark, and } 1 \text { side } \\
\text { seam; marked clockwise from lower left with } \\
\text { "86 [triangle] } 27 \text { H } 251 \text { B [in circle]" }\end{array}$ \\
\hline Collection Unit $1 *$ & white cup & 1 rim sherd with exterior molded floral decoration \\
\hline Collection Unit $1 * *$ & aqua medicine bottle & $\begin{array}{l}1 \text { neck and ring or oil finish sherd with bore diameter of } \\
0.4 \text { inch }\end{array}$ \\
\hline Collection Unit $2^{*}$ & aqua medicine bottle & $\begin{array}{l}1 \text { oval base sherd with post base seam and } 1 \text { side seam; } \\
\text { marked with " } 7 \text { OI [with diamond] } 4 \text { " over " } 1 \text { " }\end{array}$ \\
\hline Collection Unit $2 *$ & colorless cylindrical bottle & 1 base sherd marked with ". . . N ANTON . . ." \\
\hline Collection Unit $2 * *$ & aqua soda pop bottle & 1 body sherd marked with ". . . a-Co. . ." \\
\hline Collection Unit $2 * *$ & aqua bottle & 1 finish sherd \\
\hline Collection Unit $2 * *$ & colorless cylindrical beverage bottle & 1 base sherd with cup base seam \\
\hline Collection Unit $2^{* *}$ & colorless medicine bottle & $\begin{array}{l}1 \text { neck sherd with side seam and bore diameter of } 0.4 \\
\text { inch }\end{array}$ \\
\hline Collection Unit $2 * *$ & colorless bottle & $\begin{array}{l}1 \text { finish sherd with side seam over top of finish and bore } \\
\text { diameter of } 0.6 \text { inch; } 1 \text { base sherd marked with "99" or } \\
\text { "66"; } 1 \text { base sherd marked with ". . . EEE TH" over } \\
\text { "TRAD . . ."; and } 1 \text { slightly concave base sherd marked } \\
\text { with ". . . RAD . . ." over ". . . ASTO . . ." }\end{array}$ \\
\hline Collection Unit $2 * *$ & colorless drinking glass? & 1 base sherd \\
\hline Collection Unit $2^{* *}$ & colorless tableware? & $\begin{array}{l}1 \text { ca. } 10-\mathrm{cm} \text {-diameter body sherd with embossed } \\
\text { crosshatching on exterior }\end{array}$ \\
\hline Collection Unit $2^{* *}$ & colorless flat glass & $\begin{array}{l}12.19 \text {-mm-thick body sherd and } 11.41-\mathrm{mm} \text {-thick } \\
\text { body sherd (tableware?) }\end{array}$ \\
\hline Collection Unit $2^{* *}$ & colorless unknown & 1 body sherd with interior crosshatching and 1 base sherd \\
\hline Collection Unit $2 * *$ & white plate or saucer & 1 base sherd with crosshatched embossing on exterior \\
\hline Collection Unit $2^{* *}$ & white cup & 1 base fragment with cup base seam \\
\hline Collection Unit $3 *$ & dark green cylindrical bottle & 1 heel sherd; pushup present but profile unknown \\
\hline $\begin{array}{l}\text { *Surface } \\
\text { **Subsurface } \\
* * * 30-50 \mathrm{~cm} \text { below }\end{array}$ & surface & \\
\hline
\end{tabular}




\begin{tabular}{|c|c|c|}
\hline \multicolumn{3}{|l|}{ Table 26 , continued } \\
\hline Provenience & Color and Type & No. and Description of Sherd \\
\hline Collection Unit $3^{*}$ & aqua bottle & $\begin{array}{l}1 \text { double-bead or ring finish sherd with side seam over } \\
\text { the finish and bore diameter of } 0.6 \text { inch }\end{array}$ \\
\hline Collection Unit $3 *$ & colorless container & 1 base sherd marked with "T" (?) \\
\hline Collection Unit $3 *$ & brown cylindrical bottle & 1 heel sherd \\
\hline Collection Unit 3* & white plate or saucer & 1 base sherd \\
\hline Collection Unit $3^{* *}$ & aqua cylindrical bottle & 1 body sherd \\
\hline Collection Unit $3 * *$ & aqua medicine bottle & 1 panel sherd marked with ". . . R. J. . . ." \\
\hline Collection Unit $3 * *$ & solar-purpled unknown & 1 pedestal (?) sherd \\
\hline Collection Unit $3 * *$ & colorless cylindrical bottle & 1 neck sherd \\
\hline Collection Unit $3^{* *}$ & colorless medicine bottle & $\begin{array}{l}1 \text { neck and patent/extract or flat/patent finish with bore } \\
\text { diameter of } 0.4 \text { inch }\end{array}$ \\
\hline Collection Unit $3^{* *}$ & $\begin{array}{l}\text { brown beverage bottle (whiskey } \\
\text { flask?) }\end{array}$ & $\begin{array}{l}1 \text { heel sherd with post base seam and marked with } \\
" . \ldots \text { LF . . . PI . . ." }\end{array}$ \\
\hline Collection Unit $3 * *$ & brown container & 1 body sherd \\
\hline Collection Unit $4^{* *}$ & $\begin{array}{l}\text { aqua cylindrical bottle, probably } \\
\text { soda pop }\end{array}$ & 5 body sherds \\
\hline Collection Unit $4 * *$ & aqua cylindrical beverage bottle & $\begin{array}{l}1 \text { ca. } 21 / 2 \text {-inch-diameter slightly concave base sherd with } \\
\text { cup base seam and } 1 \text { side seam; marked "ROOT" }\end{array}$ \\
\hline Collection Unit $4 * *$ & aqua cylindrical bottle & $\begin{array}{l}125 / 8 \text {-inch-diameter base sherd with post base seam; and } \\
1 \text { slightly concave base sherd and } 1 \text { base sherd }\end{array}$ \\
\hline Collection Unit $4^{* *}$ & colorless octagonal bottle & 1 body sherd \\
\hline Collection Unit $4 * *$ & colorless cylindrical bottle & 1 body sherd \\
\hline Collection Unit $4^{* *}$ & colorless medicine bottle & $\begin{array}{l}11 \frac{1 / 2}{} \text { by } 3 / 4-\text { inch recessed oval base sherd with post base } \\
\text { seam and } 2 \text { side seams; marked with " } 1080^{\prime \prime} \text {; and } 1 \\
\text { neck sherd with side seam and bore diameter of } 0.4 \text { inch }\end{array}$ \\
\hline Collection Unit $4^{* *}$ & colorless bottle & 1 body sherd and 1 neck sherd with side seam \\
\hline Collection Unit $4 * *$ & cobalt blue jar & 1 finish sherd without threads; cold cream jar? \\
\hline Collection Unit $4^{* *}$ & cobalt blue container & 1 body sherd with tan enamel paint; design unknown \\
\hline Collection Unit $4^{* *}$ & white container & 1 shoulder sherd \\
\hline Collection Unit $5^{*}$ & aqua medicine & $\begin{array}{l}11 \frac{1}{2} \text { by } 3 / 4-\text { inch rectangular base sherd with flat cham- } \\
\text { fered comers, post base seam, side seam, and marked } \\
\text { " } 19 \text { " or " } 61 \text { "; and } 1 \text { rectangular base sherd with flat } \\
\text { chamfered corners and cup base seam }\end{array}$ \\
\hline
\end{tabular}




\begin{tabular}{|c|c|c|}
\hline \multicolumn{3}{|l|}{ Table 26 , continued } \\
\hline Provenience & Color and Type & No. and Description of Sherd \\
\hline Collection Unit $5^{* *}$ & colorless medicine bottle & $\begin{array}{l}1 \text { oval or rectangular recessed base sherd with rounded } \\
\text { chamfered corners, post base seam, } 1 \text { side seam, and } \\
\text { marked with "BLUE. .." }\end{array}$ \\
\hline Collection Unit $5^{* *}$ & colorless bottle & 1 shoulder sherd \\
\hline Collection Unit $5^{* *}$ & colorless container & $\begin{array}{l}1 \text { base sherd with base seam; } 1 \text { threaded-finish(?) neck } \\
\text { sherd with side seam }\end{array}$ \\
\hline Collection Unit $5^{* *}$ & large brown beer bottle & 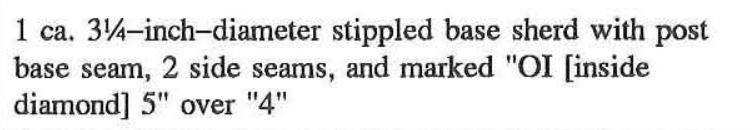 \\
\hline Collection Unit $6^{*}$ & colorless medicine bottle & $\begin{array}{l}1 \text { neck and finish sherd with side seam over the finish } \\
\text { and bore diameter of } 0.4 \text { inch }\end{array}$ \\
\hline Collection Unit $7 *$ & $\begin{array}{l}\text { olive green cylindrical wine/ } \\
\text { champagne bottle }\end{array}$ & 1 base sherd with high pushup; profile unknown \\
\hline Collection Unit $7 *$ & $\begin{array}{l}\text { emerald green cylindrical beverage } \\
\text { bottle }\end{array}$ & $\begin{array}{l}1 \text { base sherd with embossed stippling, post base seam, } \\
\text { and marked with "L . . . 5" or "S . . 7" }\end{array}$ \\
\hline Collection Unit $7 *$ & colorless cylindrical beverage bottle & $\begin{array}{l}1 \text { base fragment with post base seam, } 1 \text { side seam, and } \\
\text { marked with "AJJ . .." }\end{array}$ \\
\hline Collection Unit $7 *$ & colorless medicine bottle & $\begin{array}{l}1 \text { neck and ring or oil finish sherd with side seam over } \\
\text { top of finish and bore diameter of } 0.4 \text { inch }\end{array}$ \\
\hline Collection Unit $7 *$ & solar-purpled cylindrical bottle & 1 heel sherd \\
\hline Collection Unit $7 *$ & brown beer bottle & $\begin{array}{l}2 \text { base sherds with embossed crescents at resting point } \\
\text { and post base seams; } 1 \text { has } 1 \text { side seam and is marked } \\
\text { " } 80 " \text {; and } 1 \text { has no side seams and is marked with an } \\
\text { anchor in a square }\end{array}$ \\
\hline Collection Unit $8^{*}$ & aqua medicine bottle & 1 neck sherd with bore diameter of 0.4 inch \\
\hline Collection Unit $8^{*}$ & colorless cylindrical bottle & 1 body sherd \\
\hline Collection Unit $9 *$ & brown bottle & 1 base sherd marked with "15 I [inside O] 5" \\
\hline Collection Unit $9^{*}$ & white plate & 1 base fragment \\
\hline Feature $1 * * *$ & aqua cylindical bottle & $\begin{array}{l}4 \text { body sherds and } 1 \text { base sherd with pushup present but } \\
\text { profile unknown }\end{array}$ \\
\hline Feature $1 * * *$ & aqua flat glass & 12.09 -mm-thick body sherd \\
\hline Feature $1 * * *$ & colorless cylindrical bottle & 4 body sherds \\
\hline Feature $1 * * *$ & colorless medicine bottle & $\begin{array}{l}1 \text { neck and ring or oil finish sherd with } 2 \text { side seams and } \\
\text { bore diameter of } 0.4 \text { inch }\end{array}$ \\
\hline Feature $1 * * *$ & colorless bottle & 1 body sherd \\
\hline Feature $1 * * *$ & brown cylindrical bottle & 1 body sherd \\
\hline Feature $1 * * *$ & brown beverage bottle & 1 crown-finish sherd and 1 neck sherd \\
\hline
\end{tabular}



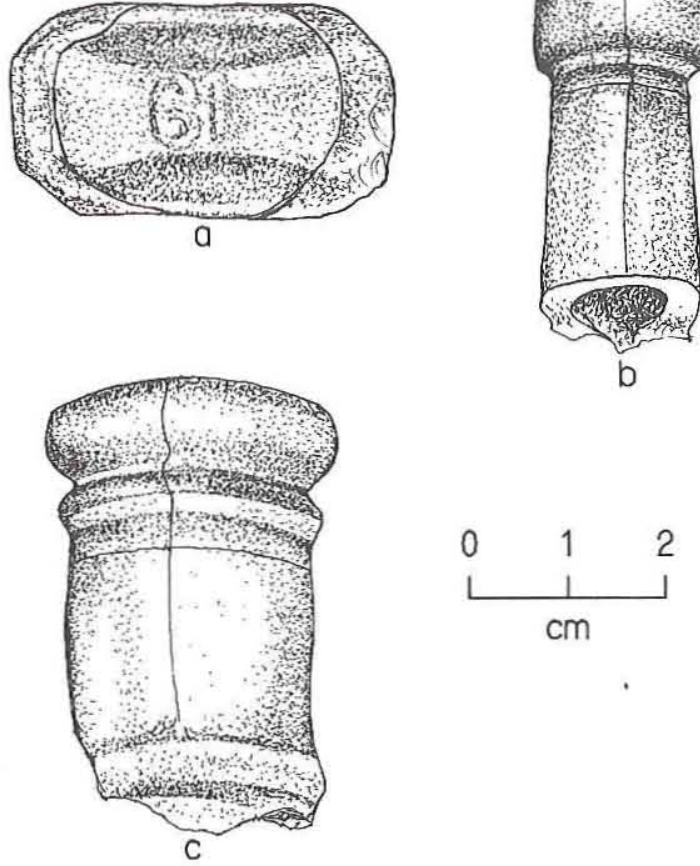

Figure 58. Temporally diagnostic bottle glass, 41HG158. (a) Aqua medicine bottle, rectangular base; (b) aqua bottle with double-bead finish; (c) colorless medicine bottle with ring or oil finish.

embossed stippling marked "CONTENT ..." over "8LGWI" over " 245 " could possibly be from the Laurens Glass Works, Laurens, South Carolina, which has been in business since 1913. The "45" could represent the year of manufacture. Their product in 1970 included sodas in emerald green (Toulouse 1971:325-326). The emerald green bottle with an unknown mark has embossed stippling indicating twentieth-century manufacture.

A colorless medicine bottle recessed base fragment is marked "BLUE . . . ." The name "Blue Ribbon" on prescription bottles is attributed to the Standard Glass Co. of Marion, Indiana, 1906-1932 (Toulouse 1971:87), but the fragmentary nature of this piece makes this attribution uncertain. The colorless cylindrical beverage bottle base with embossed stippling has a central valve mark indicating 1930s-1950s manufacture and is marked with a " $\mathrm{B}$ " inside a circle. This mark has been used by the Brockway Machine Bottle Co./Brockway Glass Co. of Brockwayville (now Brockway), Pennsylvania, since 1925 and was copyrighted in 1928 (Toulouse 1971:59-62).
A colorless cylindrical bottle base fragment marked "... . N ANTON ..." was manufactured in San Antonio. Colorless medicine bottle necks with bead (Fike 1987:Figure 2.3; Wilson 1981:111e) and ring or oil (Fike 1987:Figure 2.11) finishes (Figure 58c) have side seams extending over the finish to the bore and a seam below the base of the finish, indicating automatic bottle machine manufacture (Fike 1987:11; Miller and Sullivan 1991:109) dating to the twentieth century. An unknown finish type also has side seams extending over the top of the finish to the bore, indicating automatic bottle machine manufacture. A colorless medicine bottle finish with side seams and seam at the base of the finish also was made in an automatic bottle machine. A colorless medicine bottle patent/extract (Wilson 1981:111g) or flat or patent (Fike 1987:Figure 2.7) finish has no side seams, only a seam below the base of the finish, indicating use of a finish-forming tool. A colorless bottle or jar neck fragment has a machine-applied (threaded?) finish probably dating to the twentieth century.

A brown beer bottle base with embossed stippling is marked "... OI [inside diamond] 5" over " $4, "$ indicating manufacture by the Owens Illinois Glass Co./Owens-Illinois Inc. of Toledo, Ohio, in 1935 or 1945 using a mold designated "4" (Toulouse 1971:403). A brown bottle base is marked ". . . 15 I [inside O] 5," indicating manufacture by the Owens Illinois Glass Co./ Owens-Illinois Inc. of Toledo, Ohio, in 1955, 1965,1975 , or 1985 (Toulouse 1971:395, 403). Another brown beer bottle base has an embossed anchor and "80" and embossed crescent shapes along the resting point, indicating probable recent twentieth-century manufacture. The anchor has no crosspiece and does not resemble Anchor Hocking marks. A brown crown finish (Fike 1987:Figure 2.19; Wilson 1981:111k) with no seams probably dates no earlier than the turn of the century. Another brown beverage bottle is marked ". . LF PI . .." indicating half-pint size.

The cobalt blue jar has a seam below the base of the finish, indicating manufacture in an automatic bottle machine (Fike 1987:11).

The colorless flat glass includes one piece $1.41 \mathrm{~mm}$ thick that is probably part of a bottle, rather than a window, and is not included in the date estimates. The thickness of the two remaining fragments can provide a general estimate of 
manufacturing date using Moir's (1987b:77-78) formula based on work in Texas, the South, and the Northeast. The 2.19-mm fragment produces an 1897 estimate, and the $2.09-\mathrm{mm}$ fragment produces an 1889 estimate.

There is limited evidence for pre-Civil War occupation in the form of three handblown bottle bases. These fragments also could predate the Mexican War. There is no definite evidence of late nineteenth-century occupation, although the medicine bottles and solar-purpled glass could date to this time as well as to the first quarter of the twentieth century. At least one of the medicine bottles definitely dates no earlier than the first quarter of the twentieth century since it was made in an automatic bottle machine. The Root bottle definitely dates to the first quarter of the twentieth century. The valve marks date to the second quarter of the twentieth century. Owens-Illinois and Brockway bottles date to the second and third quarters of the twentieth century.

Glass distributions in collection units and features were examined; all artifacts are from the surface of the plowed field or road unless noted. Temporally diagnostic fragments from the first half of the nineteenth century occur in subsurface Feature 1 in Unit 4 and in Unit 3 in the eastcentral portion of the site and in Unit 7 in the west-central portion. Medicine bottles dating 1860-1920 are distributed throughout the site, occurring in subsurface Feature 1, the surface of Units 5, 6, 7, and 8, and the subsurface scraping of Units 1, 2, 3, 4, and 5. Solar-purpled glass dating 1880-World War I occurs in Unit 7.

The Root bottle dating to the first quarter of the twentieth century is from subsurface scraping in Unit 4, in the central portion of the site. Medicine bottles made in an automatic bottle machine postdating 1903 are from Units 6 and 7 in the west-central portion of the site. The Brockway bottle postdating 1923 is from Unit 1 on the east end. The 1935 or 1945 Owens-Illinois bottle is from the subsurface scraping of Unit 5 in the center. The 1934, 1944, or 1954 Owens-Illinois bottle is from Unit 2 on the east end. The 1955, 1965,1975 , or 1985 Owens-Illinois bottle is from Unit 9 on the west end. A probable twentiethcentury crown-finish bottle occurs in subsurface Feature 1. Automatic bottle machine bottles are from the surface of Units 3 and 6 and from the subsurface scraping of Units 2 and 4 . The twentieth-century Laurens Glass Works (?) emerald green bottle is from Unit 1 on the east end. Another twentieth-century bottle with embossed stippling occurs in Unit 7.

No discrete occupations can be identified at $41 \mathrm{HG} 158$ based on the dated glass artifacts. The east end of the site contains a pre-1850 bottle; 1860-1920 medicine bottles; a 1930s-1950s Brockway bottle; a 1934, 1944, or 1954 OwensIllinois bottle; automatic bottle machine bottles; and other twentieth-century bottles. The center of the site contains medicine bottles, the 1901-1932 Root bottle, and the 1934 or 1945 Owens-Illinois bottle. The west end of the site contains a pre1850 bottle; 1860-1920 medicine bottles; 1880 World War I solar-purpled glass; medicine bottles made in an automatic bottle machine; a 1955 . 1965,1975 , or 1985 Owens-Illinois bottle; and another twentieth-century bottle. Feature 1 also contains a range of types, including a pre-1850 bottle base, a medicine bottle, and a twentiethcentury crown-finish bottle.

\section{BRICKS}

Eight fragmentary bricks were collected from 41HG158. One of these is a glazed brick made of an unusual material, while the other seven are typical of hand-molded, sand-struck, soft-mud bricks. The glazed brick, collected from the blade cut fill in the area of Surface Collection Unit 1, is a large flat slab with one of its faces coated with a $1.5-\mathrm{mm}$-thick, light olive gray $(5 \mathrm{Y} 6 / 2)$, vitrified glaze. The slab is $57-60 \mathrm{~mm}$ thick, but it is too incomplete to determine its other dimensions. Notably, however, it is too large to be a standardsized brick since the fragment measures $170 \times 150 \mathrm{~mm}$. It does not exhibit any of the attributes characteristic of soft-mud, stiff-mud, or dry-pressed bricks, and its matrix is also very different. It is light gray (5YR $7 / 1$ ), medium to coarse sand with a large amount of small pebble inclusions, and is fairly soft (i.e., hardness 3-4). It looks most similar to the mud or concrete mortar that is found adhering to many of the bricks from this and other El Capote sites. A hydrochloric acid test indicates that this material has a very high calcium carbonate content. This mortarlike material may be similar to the building material called "chipichil," a mixture of lime, sand, and gravel that once commonly was used in South 
Texas for constructing floors (Graham 1992:6364).

The other seven specimens include a large fragment found in Surface Collection Unit 5 and six smaller fragments that were recovered in association with Feature 1 (two specimens in situ and four from the blade cut fill). All of these specimens exhibit at least some of the attributes that are diagnostic of hand-molded, sand-struck, soft-mud bricks (i.e., a rough struck face; smooth but sandy molded faces, sides, and ends; rounded edges and corners; and a soft [hardness 3-4], buffor salmon-colored, porous clay matrix). Of the seven specimens, four are too small to yield meaningful measurements; one fragment (approximately one-fourth) is $88+\mathrm{mm}$ long, $102-103 \mathrm{~mm}$ wide, and 61-64 mm thick; and the other two are larger and have diagnostic markings.

The largest brick fragment is $200+\mathrm{mm}$ long, 96-101 $\mathrm{mm}$ wide, and 54-62 mm thick. Despite a significant amount of recent plow and maintainer blade damage, this specimen exhibits all of the soft-mud process attributes. It also has a faint undamaged raised mark (ca. $0.5 \mathrm{~mm}$ high) centered in its molded face. The mark is a simple circle and is $21 \mathrm{~mm}$ in diameter. It has not been identified but is identical to the marks observed on bricks at the Cantu Housesite (see 41HG169, Chapter 5).

Another fragment (approximately one-third) is a midsection found in association with Feature 1. This brick is very warped and distorted, having been severely overfired, and its surface is unusually hard (i.e., hardness 6-7) but is not vitrified. The fragment is $90+\mathrm{mm}$ long, 80$89 \mathrm{~mm}$ wide, and $54-56 \mathrm{~mm}$ thick. Its sandy, porous material is buff to olive green in color, and shell fragments are the only observed inclusions. No mortar is present on this specimen, but it has a rough struck face and a smooth molded face with a raised (2-3 mm high) mark oriented vertically in its center (Figure 59). This mark has not been identified, but it appears to be a reverse-image "R" and may be a cattle brand.

\section{OTHER ARTIFACTS}

Other artifacts are two tobacco pipe fragments, a glass marble, cuprous and ferrous metal artifacts, a shell button, and bone. The tobacco pipe fragments are earthenware bowl fragments from

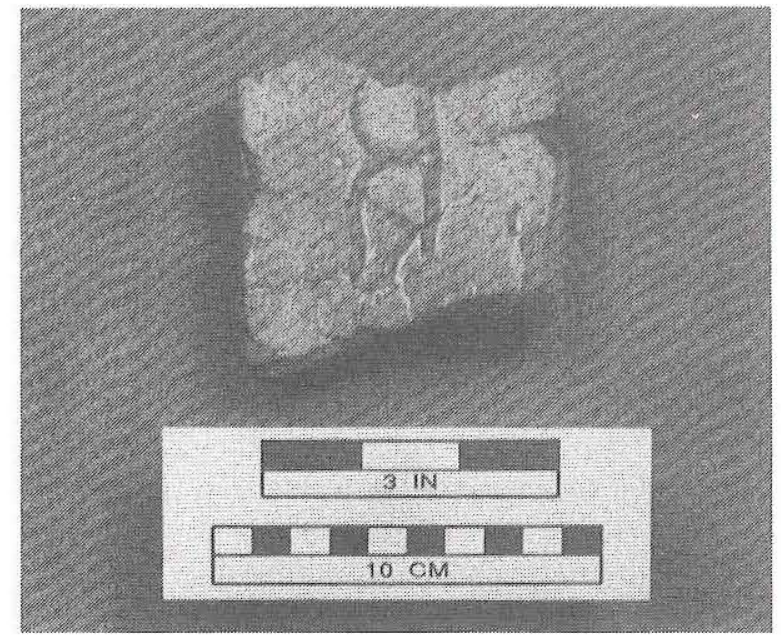

Figure 59. Raised mark (possible cattle brand) on brick from Feature 1, 41HG158.

two different pipes. One is an undecorated brownware body fragment, and the other is a buff earthenware body fragment with an exterior green lead or alkaline glaze over a simple molded leaf or geometric decoration. These pipes may date to the nineteenth or early twentieth centuries.

The glass marble is a translucent cobalt to milky blue 0.7 inch in diameter with many chips and crazing at the surface probably attributable to burning. Decoration is impossible to distinguish, but this marble probably dates to the twentieth century.

Cuprous metal artifacts consist of a sheet brass ring 0.6 inch wide crimped into a rectangular cross section measuring $0.9 \times 0.2$ inch that indicates the size of the object, probably wooden, to which the ring was attached. A flat cuprous gear with many teeth missing measures 0.8 inch in diameter and is 0.05 inch thick. This gear may have been part of a clock mechanism.

Ferrous metal artifacts consist of one harness ring approximately $2 \frac{1 / 4}{4}$ inches in diameter; one bent nail, probably cut but very corroded, and approximately 4 inches long; one nail of unknown type approximately $2 \frac{1}{2}$ inches long; five nail fragments of unknown type; two possible wire fragments $4 \frac{1}{2}$ and $5 \frac{1}{2}$ inches long; three fragments of a wire ring approximately $3 \frac{1}{2}$ inches in diameter and 0.08 inch thick, probably representing a gate fastener; one hardware plate approximately $1 \frac{1}{2} \times 2$ inches; three sheet metal fragments; and 11 unknown fragments. Cut nails, if present, reflect nineteenth-century 
occupation, and the harness ring probably indicates occupation during the nineteenth or first quarter of the twentieth century. The metal is badly corroded, and some of the fragments probably represent tin can pieces dating to the nineteenth or twentieth centuries.

The shell artifact is not iridescent and has a central hole drilled from both sides. The diameter is 0.7 inch, and the thickness 0.13 inch. The single hole and unusual thickness make use as a keeper, such as a scarf holder, more likely than use as a button.

One bone fragment was recovered from the site. This is a proximal long bone fragment, probably from a large ungulate, such as a cow.

\section{SUMMARY}

The ceramic assemblage indicates preMexican War to middle twentieth-century occupation. The glass assemblage includes handblown bottles predating the Civil War, medicine bottles dating from the Civil War to World War I, solar-purpled glass dating from the last quarter of the nineteenth to first quarter of the twentieth century, machinemade bottles dating to the twentieth century, valve marks indicating manufacture during the second quarter of the twentieth century, and marked bottles dating to the second and third quarters of the twentieth century. Other artifacts reflect nineteenth- or twentiethcentury occupation.

The bricks recovered from $41 \mathrm{HG} 158$ are not chronologically diagnostic but are quite revealing nonetheless. The unusual olive gray glazed fragment recovered from the maintainer blade cut in the vicinity of Surface Collection Unit 1 is from the area of the site where the Casares house probably was located. This odd mortarlike "brick" may be a fragment of flooring material, perhaps something similar to the lime, sand, and gravel mixture called "chipichil" (Graham 1992:63).

The other seven specimens are all handmolded, sand-struck, soft-mud brick fragments that were recovered from the surface and in the blade cut in the area where the Ramirez brick house formerly was located. Notably, one of the fragments has a circular mark that is identical to those on some of the bricks from both brick structures at the Cantu Housesite. Like the Ramirez brick house, the Cantu brick houses were built in the 1880 s, and it is likely that the bricks for all three houses were made by the same brickmaker and/or at the same brickyard. The only other identifying mark noted on the soft-mud bricks in the backward " $R$ " which could have been a cattle brand mark for the Ramirez family, although this has not been confirmed archivally.

\section{Discussion and Evaluation}

The artifacts recovered from $41 \mathrm{HG} 158$ are diagnostic of the late nineteenth or early twentieth centuries and are consistent with the archival and informant data that indicate that the houses that once existed within the area date to this time period. At least three housesites (the Luis Arebalo adobe, the Ramirez brick house built in 1883, and the Carlos Casares housesite), and possibly two others (a mid-eighteenth-century Ramirez house and the Luca Gonzales No. 2 jacal) may have existed within the area defined as 41HG158. While a continuous scatter of artifacts was observed across the entire site area, there is some variability in surface artifact density that is probably related to the locations of former structures. Relative concentrations of surface artifacts from east to west may indicate the approximate locations of individual housesites, but given the extent of the agricultural disturbances, it is impossible to link specific artifacts with specific housesites with any degree of confidence. There also is an indication based on temporal attributes that the artifacts are clustered by housesite. The east-west distribution of temporally diagnostic specimens suggests that the younger artifacts (i.e., manufactured post-1900) are scattered across the entire site, while most of the older artifacts (i.e., manufactured pre-1900) are clustered in the central portion and eastern end of the site and may be associated with the Ramirez and Casares occupations. Unfortunately, this chronological patterning is extremely weak, and it is impossible to reconstruct assemblages that might be associated with a particular housesite. Notably, overall artifact density is much higher along and near the road instead of farther north in the fields where the housesites probably were located (based on comparisons of historic and modern maps). This linear distribution most likely reflects subsequent agricultural disturbances and redistributed materials rather than an original artifact pattern 
associated with the housesites.

The Ramirez house is the only structure at 41 HG158 that is known to have been made of bricks. Notably, three observations suggest that the Ramirez brick house was very similar to the still-standing brick building at the Cantu housesite (see 41HG169, Chapter 5). First, informants indicated that the Ramirez and Cantu houses both were built in the 1880s (Cantu 1993; Ramirez et al. 1993). Second, the same marking (a small raised circle on the molded face) was observed on bricks at the Cantu housesite and on bricks from Feature 1 at 41 HG158. This feature is a buried artifact concentration located close to where the Ramirez house had stood, and the bricks found there most likely came from that house. The final similarity is that recent photographs indicate that the Ramirez house may have had square columns of brick at the corners, perhaps enclosing horcones, that held up the roof vigas (Ramirez et al. 1993). This same architectural style, apparently a blending of brick and jacal construction techniques, was observed at the Cantu house (see Figure 21).

According to informants (Ramirez et al. 1993), the Ramirez house was torn down in 1980 and most of the bricks were salvaged for use elsewhere. The 1962 USGS 7.5' Las Milpas quadrangle shows only a single structure in this area, and it is undoubtedly the Ramirez brick house. A photograph of the house provided by an informant (Olivia Ramirez) confirms its existence as late as 1977, while the 1983 photorevised version of the USGS 7.5' Las Milpas quadrangle indicates that the structure had been removed by that time.

All of the informants and historic maps clearly indicate that the house was located somewhere in the plowed field and not on the edge of the terrace. The 1939 airphoto (see Figure 4) shows that the house was located along the Old Military Road but that the terrace-edge road did not yet exist. Hence, the buried feature in the roadway is not likely to be a primary feature associated with the Ramirez housesite. Rather, it probably represents a secondary deposit of historic debris that was bladed to the edge of the terrace when the house was razed. The abundance of brick fragments indicates that the deposit may contain remnants of the original house, and the presence of charcoal and burned clay lumps may indicate the burning of brush piles, perhaps vegetation from around the house area.

Since the buried cultural debris in the roadway represents a secondary deposit, this portion of the site has a little or no research potential. Informant data suggest that all of the houses within the Ramirez Strip (including the Ramirez brick house) have been completely destroyed, and additional mechanical testing (i.e., in the field) is not likely to be productive. In addition, most of the artifacts date to the late nineteenth and/or early twentieth centuries, and the collection cannot be broken down into assemblages that are associated with specific housesites. Consequently, the site's research potential has been exhausted, and it does not warrant further investigation. It is recommended that the historic component at $41 \mathrm{HG} 158$ be considered ineligible for listing on the National Register of Historic Places and for designation as a State Archeological Landmark. 


\section{ASSESSMENTS AND RECOMMENDATIONS}

Douglas K. Boyd and Martha Doty Freeman

The Phase II archeological investigations for the Pharr-Reynosa International Bridge project consisted of additional archeological survey that documented seven new historic sites and testing and evaluation of historic and prehistoric components at three previously recorded sites. This chapter considers each archeological site in terms of its eligibility for listing on the National Register of Historic Places and for designation as a State Archeological Landmark.

Cultural resources are eligible for listing on the National Register of Historic Places, and thus are worthy of avoidance, protection, or mitigation through data recovery, if they are significant in American history, architecture, engineering, or culture (U.S. Department of the Interior, National Park Service, National Register Division 1982:1). Significant properties are those that:

possess integrity of location, design, setting, materials, workmanship, feeling, and association, and

A. that are associated with events that have made a significant contribution to the broad patterns of our history; or

B. that are associated with the lives of persons significant in our past; or

C. that embody the distinctive characteristics of a type, period, or method of construction, or that represent the works of a master, or that possess high artistic values, or that represent a significant and distinguishable entity whose components may lack individual distinction; or

D. that have yielded or may be likely to yield information important in prehistory or history [U.S. Department of the Interior, National Park Service, National Register Division 1982:1].

Criterion D is the main criterion that applies to the archeological resources, and thus it is against this criterion that the sole prehistoric and most of the historic components are judged. For the tested and evaluated historic components, however, all four of the National Register eligibility criteria are considered.

In addition to the sites located during the survey and the sites that were tested and evaluated, several historic localities outside the area of potential effects but associated with the former community of El Capote were encountered during the course of the Phase II archival and informant investigations. Out of four locations that were identified, one was field checked and recorded as site 41 HG169 (Cantu housesite), while the other three possible historic site locations remain unconfirmed (i.e., the Old Military Road and housesites east of 41HG169, the Garza Ranch No. 2 housesites, and the de la Viña Ranch). Since none of these sites are located within the area of potential effects and the sites are not subject to 
any impacts related to the construction of the Pharr-Reynosa International Bridge (see Chapter 5), no recommendations for National Register eligibility are made.

\section{ARCHEOLOGICAL SURVEY}

Phase II investigations for the Pharr-Reynosa International Bridge project area included additional archeological survey that targeted specific localities to field check probable historic site locations identified through archival research, airphoto studies, and informant interviews. As a result of this survey, seven historic components at seven sites (41HG162-41HG168) were documented. These historic components have several characteristics in common. They all represent housesites that date mainly to the late nineteenth and/or early twentieth centuries, and none are associated with important persons or significant events. No standing structures or intact features were encountered at any of these sites, and the only physical evidence of these former occupations are scatters of artifacts. Furthermore, all of these sites are located in severely disturbed agricultural fields, and they have little potential for yielding information through archeological investigation. Because of their poor archeological integrity, sites 41HG162-41HG168 fail to meet Criteria A, B, and/or D, and it is recommended that they be considered ineligible for listing on the National Register of Historic Places and for designation as State Archeological Landmarks (Table 27).

\section{TESTING AND EVALUATION}

Phase II investigations in the Pharr-Reynosa International Bridge project area included archeological testing and evaluation of historic components at 41HG153, 41HG156, and 41HG158 and of the prehistoric component at 41HG153. Recommendations of the eligibility of each component for listing on the National Register of Historic Places and for designation as a State Archeological Landmark are considered separately below (see Table 27).

\section{Historic Components}

$41 H G 153$

The historic component at 41HG153 may have
TABLE 27

RECOMMENDATIONS FOR NATIONAL REGISTER AND STATE ARCHEOLOGICAL LANDMARK ELIGIBILITY OF ARCHEOLOGICAL SITES

\begin{tabular}{|c|c|c|}
\hline \multicolumn{3}{|c|}{ Archeological Survey } \\
\hline Site No. & Component & $\begin{array}{l}\text { Recommended } \\
\text { Eligibility } \\
\text { Status }\end{array}$ \\
\hline $\begin{array}{l}41 \mathrm{HG} 162 \\
41 \mathrm{HG} 163 \\
41 \mathrm{HG} 164 \\
41 \mathrm{HG} 165 \\
41 \mathrm{HG} 166 \\
41 \mathrm{HG} 167 \\
41 \mathrm{HG} 168\end{array}$ & $\begin{array}{l}\text { Historic } \\
\text { Historic } \\
\text { Historic } \\
\text { Historic } \\
\text { Historic } \\
\text { Historic } \\
\text { Historic }\end{array}$ & $\begin{array}{l}\text { Not eligible } \\
\text { Not eligible } \\
\text { Not eligible } \\
\text { Not eligible } \\
\text { Not eligible } \\
\text { Not eligible } \\
\text { Not eligible }\end{array}$ \\
\hline \multicolumn{3}{|c|}{ Testing and Evaluation } \\
\hline Site No. & Component & $\begin{array}{l}\text { Recommended } \\
\text { Eligibility } \\
\text { Status/Criteria }\end{array}$ \\
\hline $\begin{array}{l}41 \mathrm{HG} 153 \\
41 \mathrm{HG} 156 \\
41 \mathrm{HG} 158\end{array}$ & $\begin{array}{l}\text { Historic } \\
\text { Prehistoric } \\
\text { Historic } \\
\text { Historic }\end{array}$ & $\begin{array}{l}\text { Not eligible } \\
\text { Not eligible } \\
\text { Eligible/A, C, D } \\
\text { Not eligible }\end{array}$ \\
\hline
\end{tabular}

been associated with the Anaya family prior to 1850 , but after that time it became the original location of the Guillermo Garza Ranch and was occupied until the late nineteenth or early twentieth century. The historic occupations date to the Republic of Texas period and appear to be associated with two families, the Anayas and the Garzas, who figured prominently in the settling of El Capote and the region. Unfortunately, extensive mechanical testing has revealed that the site is severely disturbed by modern agricultural practices (i.e., land leveling and deep plowing). All of the nineteenth-century artifacts were found in disturbed contexts, and no intact cultural deposits or features associated with the historic occupations were observed. Because it is totally lacking in integrity, it is recommended that $41 \mathrm{HG} 153$ be considered ineligible for listing on the National Register of Historic Places and for designation as a State Archeological Landmark.

\section{$41 H G 156$}

Site 41 HG156 is a brick factory that was 
associated with Pedro Guajardo until ca. 1922 and subsequently with Eduardo G. Vela between 19461948. While this site does not appear to meet National Register Criterion B, it does meet Criteria A, C, and D. Lacking a definitive and welldocumented statement of context for the brickmaking industry in the Lower Rio Grande Valley, it is difficult to fully evaluate this site. However, 41HG156 is a well-preserved example of a smallscale, nonmechanized brick plant of the type that was once ubiquitous in the region (Criterion C). Most of these kinds of sites apparently have been destroyed by the extensive development in the region, and their rarity enhances the importance of this site: Site 41HG156 is one of the few remaining vestiges of a once widespread and thriving cottage industry that has disappeared almost completely (Criterion A). In terms of its integrity, 41 HG156 is largely intact, and a significant portion of the kiln structure and other features related to brick manufacturing are preserved. Thus, it has the potential to yield significant information through intensive archeological investigation (Criterion D). It is recommended that site 41 HG 156 be considered eligible for listing on the National Register of Historic Places and for designation as a State Archeological Landmark.

If $41 \mathrm{HG} 156$ will be subject to any impacts related to the construction of the Pharr-Reynosa International Bridge and additional archeological investigations become necessary, several general recommendations are offered in order to maximize the data recovery. First and foremost, a regional context for understanding the origin and development of brickmaking in the Lower Rio Grande Valley of Texas is essential for placing site $41 \mathrm{HG} 156$ in its proper perspective. Compiling this context also would greatly enhance the interpretations of the features at the site and the activities that occurred there. More-intensive informant interviews, specifically targeted toward the brick factory, also are likely to be productive. It is possible that some of the people who actually worked at the brick factory during its latest use are still living. The main focus of additional oral history research should be to identify, as precisely as possible, such details as the brickmaking processes that were employed, when and how many times the kiln was used, what types of bricks were made there and where they went, and who the master brickmakers were. The list of research questions should not be limited to these few examples but should be expanded to cover a wider range of information.

Archeologically, there are numerous research questions and analytical techniques that might be applicable for a data recovery program for 41HG156. Investigation of the kiln and its attached features is essential for identifying the nature of its construction and the details of its use. Complete excavation of the kiln's interior is needed to determine the nature of the submerged firing chamber and to identify the number and direction of the firing channels and openings. Interior excavation also would be likely to answer many questions about original wall construction and rebuilding episodes, particularly for the east, south, and west walls since they are partially or wholly obscured by sediment. Detailed architectural drawings of the kiln's interior should be made after excavation, and samples of the bricks on and near the floor should be taken for comparative analyses.

Excavations immediately outside the kiln walls also could provide valuable information. Trenching to the east and south could reveal the nature of the entryways and access to the kiln (e.g., were they flush with the floor or did they step down into the kiln?), while trenching to the north and west could clarify details of the wall construction and identify the nature of the brick rubble mound that is butted up against the kiln (e.g., did this mound result entirely from discarding of platting [waste debris] used to cover the kiln during the final stages of firing?). Samples of these materials should be taken for comparative analyses. Also, the complete bricks in the Feature 1 mound should be collected for comparative analyses since they most likely represent intact bricks as opposed to the ubiquitous waste materials.

Investigations of ancillary features also are essential to a complete understanding of the site. Hand excavation and/or mechanical trenching of selected waster piles (e.g., Features 2 and 7 represent both Types 1 and 2 bricks) could give clues to their formation, and samples of bricks from these features should be taken for comparative analysis. This is especially critical for Feature 7 to confirm that Type 2 bricks were made on-site. Mechanical trenching around the edges of the large borrow pit (Feature 8) would define its size more precisely and identify the extent and nature of the debris dumped there (and probably increase the range of variability in dumped 
materials). A detailed stratigraphic profile of the sediments along the north edge of the borrow pit is needed to identify and sample the sediments that were being used for brickmaking. In addition, mechanical trenching and stratigraphic profiling of the Feature 11 depression could help to determine the function of that pit.

From an analytical standpoint, a thorough investigation should include some attempt to quantify, define, and contrast the local clays (sampled from Feature 8) and the bricks that were produced on-site. A comparative study of the natural clay deposits and the locally manufactured bricks could address a wide range of research questions and minimally should incude data derived from the following: (1) textural and chemical analyses to identify general sediment characteristics such as grain size, percent organic matter, percent carbonates, and soil pH; (2) detailed chemical analyses, such as neutron activation analysis, to identify specific and potentially diagnostic trace elements in the clays (e.g., Gilbert et al. 1993); and (3) petrographic thin section analysis to characterize the matrix. By combining these various types of compositional analyses, a comprehensive study could address a wide range of research questions relating to sourcing (i.e., linking the source of raw material to the finished artifact) and technology (e.g., to identify whether brickmakers used raw clays or altered them with additives). This study also should be expanded to include some of the Mexicanmade bricks dumped at $41 \mathrm{HG} 156$ to determine if the bricks manufactured at the site are of the same basic composition and quality as their counterparts made just across the Rio Grande. Ultimately, a comparative compositional analysis should attempt to characterize and contrast the attributes of the bricks manufactured at $41 \mathrm{HG} 156$ versus the bricks that were discarded there.

\section{$41 H G 158$}

The historic component at $41 \mathrm{HG} 158$ is a long continuous surface artifact scatter associated with the locations of three to five former housesites in an area known locally as the Ramirez Strip. Three housesites within the site area are known to have been associated with, from east to west, the Arebalo, Ramirez, and Casarez families, but identification of the two other possible housesites is problematic. No structures are associated with any of these housesites, and a single buried feature found by mechanical testing in the road is a concentration of historic debris associated with the former Ramirez brick house. Because of its location and context, this feature is considered to be a recent secondary dump of historic structural materials and artifacts. Informant and archeological data indicate that the site area is severely disturbed, and there is little potential for deriving important information from continued archeological research at this site. The site was occupied during the latter half of the nineteenth century and the first half of the twentieth century, but separation of the material culture into discrete time periods or by households is impossible.

Because of its poor archeological integrity, 41 HG158 does not meet Criterion D, and it is not associated with important events or individuals (Criteria A and B). As a result, it is recommended that $41 \mathrm{HG} 158$ be considered ineligible for listing on the National Register of Historic Places and for designation as a State Archeological Landmark.

\section{Prehistoric Component}

The prehistoric component at $41 \mathrm{HG} 153$ is limited to a very sparse surface scatter of artifacts and is confined to the west end of the site. Archeological testing of this Late Prehistoric component consisted of the mechanical excavation of six backhoe trenches and hand excavation of one $1-x-1-m$ unit. No cultural materials were recovered by the testing, and no definitive evidence of any prehistoric deposits or features was encountered. It is likely that the bone originally thought to be associated with the prehistoric component is actually associated with late historic or recent occupation/use of the site (i.e., considerable bones were found in association with the buried fenceline during testing of the historic component). Thus, a single Starr arrow point, a few flakes, and some mussel shell fragments constitute the only evidence of prehistoric occupation. Because of the low artifact density and lack of buried or intact deposits or features, the prehistoric component does not meet National Register Criterion $\mathrm{D}$, and its potential to provide information to address regional research issues is very limited. Therefore, it is recommended that the prehistoric component at 41HG153 be considered ineligible for listing on the National Register of Historic Places and for designation as a State Archeological Landmark. 


\section{REFERENCES CITED}

Abbott, James T.

1990 Geomorphic and Geoarcheological Investigations. In Phase II Investigations at Prehistoric and Rock Art Sites, Justiceburg Reservoir, Garza and Kent Counties, Texas, Vol. 1, by Douglas K. Boyd,' James T. Abbott, William A. Bryan, Colin M. Garvey, Steve A. Tomka, and Ross C. Fields, pp. 23-61. Reports of Investigations No. 71. Prewitt and Associates, Inc., Austin.

Anders, Evan

1982 Boss Rule in South Texas: The Progressive Era. University of Texas Press, Austin.

Anderson, Adrienne

1968 The Archaeology of Mass-Produced Footwear. Historical Archaeology 2:56-65.

Anderson, A. E.

1932 Artifacts of the Rio Grande Delta Region. Bulletin of the Texas Archeological and Paleontological Society 4:29-31.

Anonymous

1912 Richest Indian-A Brick Manufacturer: Brickmaking, One Branch of the Immense Business Interests of Lon C. Hill, Educated Redskin who Helped to Civilize Lone Star State. Brick and Clay Record 41(8):312313.

1914 Where Brickmaking Is a Side Line: A Farmer's Brick Plant Where the Same Methods Are in Use as Prevailed in the Days of the Flintlock and Powder Horn. Brick and Clay Record (August 4, 1914):253-255.

Archivo Historico de Reynosa

various Expediente 11, Caja 2, Tesorería.
Banks, Cynthia R.

1983 Brazos Santiago Depot and Fort Polk, Cameron County, Texas: Contexts of the Sites and Analysis of the Ceramics from 1967 and 1980 Investigations. Unpublished Master's thesis, The University of Texas at Austin.

Barnes, Virgil E.

1976 Geologic Atlas of Texas, McAllen-Brownsville Sheet. Bureau of Economic Geology, The University of Texas at Austin.

Berge, Dale L.

1980 Simpson Springs Station: Historical Archaeology in Western Utah 1974-1975. Cultural Resource Monograph 6. Bureau of Land Management, Utah State Office, Salt Lake City (?).

Bettis, E. Arthur, III

1984 New Conventions for the Designation of Soil Horizons and Layers. Plains Anthropologist 29(103):57-59.

Birkeland, Peter W.

1984 Soils and Geomorphology. Oxford University Press, Oxford.

Black, Stephen L.

1989 South Texas Plains. In From the Gulf to the Rio Grande: Human Adaptation in Central, South, and Lower Pecos Texas, by Thomas R. Hester, Stephen L. Black, D. Gentry Steele, Ben W. Olive, Anne A. Fox, Karl J. Reinhard, and Leland C. Bement, pp. 39-62. Research Series No. 33. Arkansas Archeological Survey, Fayetteville.

Blair, W. Frank

1950 The Biotic Provinces of Texas. The Texas Journal of Science 2(1):93-117. 
Blum, Michael D., and Salvatore Valastro, Jr.

1989 Response of the Pedernales River of Central Texas to Late Holocene Climatic Change. Annals of the Association of American Geographers 79(3):435-456.

Bousman, C. Britt, Steve A. Tomka, and Gail L. Bailey 1990 Prehistoric Archeology and Paleoenvironments in Hidalgo and Willacy Counties, South Texas: Results of the Phase II Test Excavations. Reports of Investigations No. 76. Prewitt and Associates, Inc., Austin.

Brown, L. F., Jr., J. L. Brewton, T. J. Evans, J. H. McGowen, W. A. White, C. G. Groat, and W. L. Fisher

1980 Environmental Geologic Atlas of the Texas Coastal Zone-Brownsville-Harlingen Area. Bureau of Economic Geology, The University of Texas at Austin.

Buol, S. W., F. D. Hole, and R. J. McCracken '

1980 Soil Genesis and Classification. 2nd ed. Iowa State University Press, Ames.

Cantu, Prudencio

1993 Interview with Prudencio Cantu, September 3, 1993, E1 Capote, Texas, by Joe Graham.

Clark, John W., Jr.

1984 Archaeological Test Excavations at An Early Twentieth Century Dump in North San Antonio, Bexar County, Texas. Publications in Archaeology Report 26. Texas State Department of Highways and Public Transportation, Highway Design Division, Austin.

Collins, K.

1984 Status and Management of Native South Texas Brushlands. U.S. Fish and Wildlife Service, Ecological Service, Corpus Christi, Texas.

Collins, Michael B., Thomas R. Hester, and

Frank A. Weir

1969 The Floyd Morris Site (41CF2), a Prehistoric Cemetery Site in Cameron County, Texas. Part I in Two Prehistoric Cemetery Sites in the Lower Rio Grande Valley of Texas, by Thomas Roy Hester, Michael B. Collins, Frank A. Weir, and Frederick Ruecking, Jr. Bulletin of the Texas Archeological Society 40:119-146.

Comisión Pesquisidora

1874 Informe de la Comisión Pesquisidora de la Frontera del Norte: Al Ejecutivo de la
Union en Cumplimiento del Artículo 3. de la Ley de 30 de Setiembre de 1872. Monterey, Mayo 15 de 1873. Diaz de Leon y White, Méjico.

Coysh, A. W., and R. K. Henrywood

1982 The Dictionary of Blue and White Printed Pottery 1780-1880. Antique Collectors' Club, Woodbridge, Suffolk, England.

Dames and Moore, Inc.

1992 National Historic Landmark Nomination: Louisiana-Rio Grande Canal Company Irrigation System. Draft nomination on file, Texas Historical Commission, Austin.

Day, D. William, Jane Laurens-Day, and Elton R. Prewitt 1981 Cultural Resources Survey and Assessments. in Portions of Hidalgo and Willacy Counties, Texas. Reports of Investigations No. 15. Prewitt and Associates, Inc., Austin.

DeBolt, C. Gerald

1988 The Dictionary of Whiteware and Porcelain American Pottery Marks. Charles E. Tuttle Co., Rutland, Vermont.

Dial, Susan W.

1992 Ceramics. In Archaeological Investigations in Alamo Plaza, San Antonio, Bexar County, Texas, 1988 and 1989, by Anne A. Fox, pp. 29-46. Archaeological Survey Report No. 205. Center for Archaeological Research, The University of Texas at Austin.

Dyer, Malcolm, and Dr. Robert Norton

1992 Interview with Malcolm Dyer and Dr. Robert Norton, October 21, 1992, south of Pharr, by Martha Doty Freeman.

Earls, Amy C., Terri L. Myers, Brian S. Shaffer, Karl W. Kibler, Karen M. Gardner, Laurie S. Zimmerman, Elton R. Prewitt, and Sandra L. Hannum

1993 Testing and Data Recovery at the Townsite of Old Velasco (41BO125), Brazoria County, Texas. Reports of Investigations No. 94 (review draft). Prewitt and Associates, Inc., Austin.

Farmer, Jim

1952 Irrigation Enters Valley - 1847. The Daily Review (December 7).

Fike, Richard E.

1987 The Bottle Book: A Comprehensive Guide to Historic, Embossed Medicine Bottles. 
Gibbs M. Smith, Inc., Peregrine Smith Books, Salt Lake City.

Foster, Joseph Arnold (editor)

1969 Accounts of Brickmaking in England

Published Between 1800 and 1850. Contributions to a Study of Brickmaking in America. Privately published by the author, Claremont, California.

1970 Accounts of Brickmaking in America Written Before 1850. Contributions to a Study of Brickmaking in America. Privately printed, Claremont, California.

1971 Accounts of Brickmaking in America Published Between 1850 and 1900. Contributions to a Study of Brickmaking in America. Privately printed, Claremont, California.

Fox, Anne A.

1986 Ceramics. In La Villita Earthworks (41BX677): San Antonio, Texas: A Preliminary Report of Investigations of Mexican Siege Works at the Battle of the Alamo, assembled by Joseph H. Labadie, pp. 107-127. Archaeological Survey Report No. 159. Center for Archaeological Research, The University of Texas at Austin.

Frazier, David E.

1974 Depositional-Episodes: TheirRelationship to the Quaternary Stratigraphic Framework in the Northwestern Portion of the Gulf Basin. Geological Circular 74-1. Bureau of Economic Geology, The University of Texas at Austin.

Freeman, Allan S., Garman Harbottle, and Daniel DeNoyelles

1993 A Ceramic Chemistry Archive for New Netherland/New York. Historical Archaeology 27(3):17-56.

Freeman, Martha Doty, and Javier Sánchez García

1991 Historic Designations in the U.S. and Mexico: Texas, Tamaulipas and Nuevo León. In A Shared Experience: The History, Architecture and Historic Designations of the Lower Rio Grande Heritage Corridor, edited by Mario L. Sánchez, pp. 73-129. Los Caminos del Rio Heritage Project and the Texas Historical Commission, Austin.
Galloway, W. E., and David K. Hobday

1983 Terrigenous Clastic Depositional Systems: Applications to Petroleum, Coal, and Uranium Exploration. Springer-Verlag, New York.

Garza, Roberto, and Nestor Garza, Jr.

1993 Interview with Roberto Garza and Nestor Garza, Jr., September 11, 1993, by Joe Graham.

Garza, Roberto, Nestor Garza, Jr., Manuel E. Cantu, and Prudencio Cantu

1992 Interview with Roberto Garza, Nestor Garza, Jr., Manuel E. Cantu, and Prudencio Cantu, November 9, 1992, in Pharr, Texas, and the project area, by Martha Doty Freeman.

Gates, William C., Jr., and Dana E. Ormerod

1982 The East Liverpool, Ohio, Pottery District: Identification of Manufacturers and Marks. Historical Archaeology 16(1-2):1-358.

Gilbert, Allan S., Garman Harbottle, and Daniel DeNoyelles 1993 A Ceramic Chemistry Archives for New Netherland/New York. Historical Archaeology 27(3):17-56.

Godden, Geoffrey A.

1964 Encyclopaedia of British Pottery and Porcelain Marks. Crown Publishers, Inc., New York.

Gonzalez, Jovita

1930 Social Life in Cameron, Starr, and Zapata Counties. Unpublished Master's thesis, The University of Texas.

Graf, LeRoy P.

1942 The Economic History of the Lower Rio Grande Valley, 1820-1875. 2 vols. Unpublished Ph.D. dissertation, Harvard University, Cambridge.

Graham, Joe S.

1992 The Built Environment in South Texas: The Hispanic Legacy. In Hispanic Texas: A Historical Guide, edited by Helen Simons and Cathryn A. Hoyt, pp. 58-75. The -University of Texas Press, Austin.

Gurcke, Karl

1987 Bricks and Brickmaking: A Handbook for Historical Archaeology. University of Idaho Press, Moscow. 
Hall, Grant D., Michael B. Collins, and Elton R. Prewitt 1987 Cultural Resources Investigations Along Drainage Improvements, Hidalgo and Willacy Counties, Texas: 1986 Investigations. Reports of Investigations No. 59. Prewitt and Associates, Inc., Austin.

Hall, Stephen A.

1977 Late Quaternary Sedimentation and Paleoecologic History of Chaco Canyon. Geological Society of America Bulletin 88:1593-1618.

1988 Environment and Archaeology of the Central Osage Plains. Plains Anthropologist 33(120):203-218.

Hawker, H. W., M. W. Beck, and R. E. Devereux 1929 Soil Survey of Hidalgo County, Texas. U.S. Department of Agriculture, Bureau of Chemical and Soils Series 1925, No. 13. Superintendent of Documents, Washington, D.C.

Herrera Perez, Octavio

1989 Monografía de Reynosa. Instituto Tamau lipeco de Cultura, Tamaulipas, Mexico.

Herskovitz, Robert M.

1978 Fort Bowie Material Culture. Anthropological Papers 31. The University of Arizona, Tucson.

Hester, Thomas R.

1981 Tradition and Diversity Among the Prehistoric Hunters and Gatherers of Southem Texas. Plains Anthropologist 26(92):119-128.

Hester, Thomas R., and R. W. Rodgers

1971 Additional Data on the Burial Practices of the Brownsville Complex. The Texas Journal of Science 22(4):367-372.

Hester, Thomas R., and Frederick Ruecking, Jr.

1969 Additional Materials from the Ayala Site: A Prehistoric Cemetery Site in Hidalgo County, Texas. Part II in Two Prehistoric Cemetery Sites in the Lower Rio Grande Valley of Texas, by Thomas R. Hester, Michael B. Collins, Frank A. Weir, and Frederick Ruecking, Jr. Bulletin of the Texas Archeological Society 40:119-146.

Hidalgo County

Court Records

Deed Records

Tax Records

Hidalgo County Historical Commission

n.d.a Jackson Ranch File. Rio Grande Valley Historical Collection, The University of Texas
Pan American, Edinburg.

n.d.b El Capote Ranch File. Rio Grande Valley Historical Collection, The University of Texas Pan American, Edinburg.

Hildebrand, Walter W.

1950 The History of Cameron County, Texas. Unpublished Master's thesis, North Texas State College, Denton.

Holliday, Vance T.

1983 Stratigraphy and Soils of Lubbock Lake Landmark Area. In Guidebook to the Central Llano Estacado, edited by Vance T. Holiday, pp. 25-80. International Center for Arid and Semi-Arid Land Studies and The Museum, Texas Tech University, Lubbock.

Hunt, C. B.

1974 Natural Regions of the United States and Canada. W. H. Freeman, San Francisco.

Jacobs, Jerry L.

1981 Soil Survey of Hidalgo County, Texas. United States Department of Agriculture, Soil Conservation Service in cooperation with the Texas Agricultural Experiment Station.

Jahrsdoerfer, Sonja E., and David M. Leslie, Jr.

1988 Tamaulipan Brushland of the Lower Rio Grande Valley of South Texas: Description, Human Impacts, and Management Options. Biological Report 88(36). U.S. Fish and Wildlife Service, Washington, D.C.

Jelks, Edward B.

1978 Diablo Range. In Chronologies in New World Archaeology, edited by R. E. Taylor and Clement W. Meighan, pp. 71-112. Academic Press, New York.

Jones, Olive, and Catherine Sullivan

1989 The Parks Canada Glass Glossary for the Description of Containers, Tableware, Flat Glass, and Closures. Rev. ed. Studies in Archaeology, Architecture, and History. National Historic Parks and Sites, Canadian Parks Service, Environment Canada, Ottawa, Ontario.

Ketchum, William C., Jr.

1987 American Country Pottery: Yellowware and Spongeware. Alfred A. Knopf, New York.

Kibler, Karl W.

1994 Archeological and Geomorphological Investigations at Prehistoric Sites 41WY50 
and 41WY60, Willacy County, Texas. Reports of Investigations No. 95. Prewitt and Associates, Inc., Austin.

Kibler, Karl W., and Martha Doty Freeman

1993 Preliminary Cultural Resources Investigations for the Pharr-Reynosa International Bridge, Hidalgo County, Texas. Reports of Investigations No. 90. Prewitt and Associates, Inc., Austin.

Kovel, Ralph and Terry

1986 Kovel's New Dictionary of Marks. Crown Publishers, Inc., New York.

Lebo, Susan A.

1991 Historic Artifact Classification. Appendix D in Archaeological Testing of the Lewisville Lake Shoreline, Denton County, Texas, by Kenneth L. Brown and Susan A. Lebo, pp. 161-172. Submitted by Institute of Applied Sciences, University of North Texas, Denton, to U.S. Army Corps of Engineers, Fort Worth.

Lehner, Lois

1988 Lehner's Encyclopedia of U.S. Marks on Pottery, Porcelain, and Clay. Collector Books, Paducah, Kentucky.

Lewis, Kenneth E., and Helen W. Haskell

1981 The Middleton Place Privy: A Study of Discard Behavior and the Archeological Record. Research Manuscript Series No. 174. Institute of Archeology and Anthropology, University of South Carolina, Columbia.

Lucas, Mrs. Wilber

1993 Telephone interview with Mrs. Wilber Lucas, December 16, 1993, near Fay's Comer, Texas, by Andrés Tijerina, Kingsville, Texas.

MacNeish, Richard S.

1947 A Preliminary Report on Coastal Tamaulipas, Mexico. American Antiquity 13(1):1-15.

1958 Preliminary Archaeological Investigations in the Sierra de Tamaulipas, Mexico. Transactions of the American Philosophical Society 48:6.

Majewski, Teresita, and Michael J. O'Brien

1987 The Use and Misuse of Nineteenth-Century English and American Ceramics in Archaeological Analysis. In Advances in Archaeological Method and Theory, Vol. 11, edited by Michael B. Schiffer, pp. 97-209. Academic Press, Inc., New York.
Mallouf, Robert J., Barbara J. Baskin, and Kay Killen 1977 APredictive Assessment of Cultural Resources in Hidalgo and Willacy Counties, Texas. Survey Report 23. Office of the State Archeologist, Texas Historical Commission, Austin.

Mason, J. Alden

1935 The Place of Texas in Pre-Columbian Relationships Between the United States and Mexico. Bulletin of the Texas Archeological and Paleontological Society 7:29-46.

McAllen Genealogical Society

1976 El Capote Ranch Cemetery. Hidalgo County ranch cemeteries survey by Joe Fallin and Dale Swartzmiller, March 1976. Unpublished ms. on file, Rio Grande Valley Historical Collection, The University of Texas Pan American, Edinburg.

Miller, George L.

1991 A Revised Set of CC Index Values for Classification and Economic Scaling of English Ceramics from 1787 to 1880 . Historical Archaeology 25(1):1-25.

Miller, George L., and Catherine Sullivan

1991 Machine-made Glass Containers and the End of Production for Mouth-blown Bottles. In Approaches to Material Culture Research for Historical Archaeologists, compiled by George L. Miller, Olive R. Jones, Lester A. Ross, and Teresita Majewski, pp. 99-112. The Society for Historical Archaeology, California, Pennsylvania.

Moir, Randall W.

1987a Refined Earthenwares and Rural Ceramic Traditions. In Historic Buildings, Material Culture, and People of the Prairie Margin: Architecture, Artifacts, and Synthesis of Historic Archaeology, edited by David H. Jumey and Randall W. Moir, pp. 97-120. Richland Creek Technical Series, Vol. V. Archaeology Research Program, Institute for the Study of Earth and Man, Southem Methodist University, Dallas.

1987b Socioeconomic and Chronometric Patteming of Window Glass. In Historic Buildings, Material Culture, and People of the Prairie Margin: Architecture, Artifacts, and Synthesis of Historic Archaeology, edited by David H. Jumey and Randall W. Moir, pp. 73-81. Richland Creek Technical Series, Vol. V. 
Archaeology Research Program, Institute for the Study of Earth and Man, Southern Methodist University, Dallas.

Montejano, David

1987 Anglos and Mexicans in the Making of Texas, 1836-1986. University of Texas Press, Austin.

Moore, Gary L., Frank A. Weir, John E. Keller, R. Whitby Jarvis, Cathrine H. Yates, K. Joan Jelks, and Phillip A. Bandy

1972 Temporary Capitol of Texas, 1883-88. Publications in Archaeology 1. Texas Highway Department, Austin.

Munsey, Cecil

1970 The Illustrated Guide to Collecting Bottles. Hawthom Books, New York.

Natural Fibers Information Center

1987 The Climates of Texas Counties. Bureau of Business Research, The University of Texas at Austin, in cooperation with the Office of the State Climatologist, Texas A\&M University. The University of Texas at Austin.

Pharr Press, The

Pierce, Frank C.

1917 A Brief History of the Lower Rio Grande Valley. George Banta Publishing Company, Menasha, Wisconsin.

Ponce, Joe

1993 Telephone conversation with Joe Ponce, December 31, 1993, Edinburg, Texas, by Andrés Tijerina.

Pool, Juliann C.

1991 An Overview of Nineteenth and Twentieth Century Buttons. Rev. Research Notes, Historic Sites and Materials, No. 1. Texas Parks and Wildlife Department, Austin.

Prewitt, Elton R.

1974 Preliminary Archeological Investigations in the Rio Grande Delta Area of Texas. Bulletin of the Texas Archeological Society 45:55-65.

Prewitt, Elton R., and Jeffrey G. Paine

1987 The Swan Lake Site (41AS16) on Copano Bay, Aransas County, Texas: Settlement, Subsistence, and Sea Level. Bulletin of the Texas Archeological Society 58:147-174.
Price, Cynthia R.

1979 19th Century Ceramics . . . in the Eastern Ozark Border Region. Center for Archaeological Research, Southwest Missouri State University, Springfield.

Ramirez, Olivia, Rogelio Ramirez, and Maria de la Paz 1993 Interview with Olivia Ramirez, Rogelio Ramirez, and Maria de la Paz, September 10, 1993, Fay's Corner, Texas, by Joe Graham.

Randall, Mark

n.d. Identifying and Dating 19th and 20th Century Marbles. Ms. in possession of the author.

Rubel, Arthur J.

1966 Across the Tracks: Mexican-Americans in a Texas City. University of Texas Press, Austin.

Salinas, Martín

1986 Historic Indian P'opulations of the Rio Grande Delta and Vicinity: An Approach to Definition of Basic Ethnic Units. Unpublished Master's thesis, Department of Anthropology, The University of Texas at Austin.

Sánchez, Joseph P.

1992 From El Paso to Eagle Pass: Spanish Entradas along the Lower Rio Grande in the Sixteenth and Seventeenth Centuries. Bulletin of the Texas Archeological Society 63:53-66.

Sayles, E. B.

1935 An Archaeological Survey of Texas. Medallion Papers 17. Gila Pueblo, Globe, Arizona.

Scott, Florence Johnson

1970 Historical Heritage of the Lower Rio Grande. Texian Press, Waco.

Schumm, S. A.

1977 The Fluvial System. John Wiley and Sons, New York.

Simons, Helen, and Cathryn A. Hoyt

1992

Hispanic Texas: A Historical Guide. University of Texas Press, Austin.

Steinbomer, Robert A.

1980 Brickmaking in Texas: A History of the Industry and Its Products. Unpublished ms. submitted to the Texas Architectural Foundation.

1981 The Texas Brick: A Brief History of the 
Industry and Its Product. Texas Architect (January/February).

Stewart-Abemathy, Leslie C.

1986 The Moser Farmstead, Independent But Not Isolated: The Archeology of a Late Nineteenth Century Ozark Farmstead. Research Series 26. Arkansas Archeological Survey, Fayetteville.

Stuiver, M., and G. W. Pearson

1993 High-Precision Bidecadal Calibration of the Radiocarbon Time Scale, AD 1950-500 BC and 2500-6000 BC. Radiocarbon 35:1-23.

Texas. General Land Office

1882a San Patricio First Class 691. Abstract 40. Patented to the heirs and legal assigns of Captain Juan José Hinojosa, October 31, 1882.

1882b San Patricio First Class 692. Abstract 45. Patented to the heirs and assigns of Antonio Velasco, January 18, 1882.

Thompson, Jerry D.

1991 Historical Survey. In A Shared Experience: The History, Architecture and Historic Designations of the Lower Rio Grande Heritage Corridor, edited by Mario $\mathrm{L}$. Sánchez, pp. 11-71. Los Caminos del Rio Heritage Project and the Texas Historical Commission, Austin.

Toulouse, Julian H.

1971 Bottle Makers and Their Marks. Thomas Nelson, Inc., New York.

Turner, Ellen Sue, and Thomas R, Hester

1985 A Field Guide to Stone Artifacts of Texas Indians. Texas Monthly Press, Austin.

Tyler, Ronnie C.

1973 Santiago Vidaurri and the Southern Confederacy. Texas State Historical Association, Austin.

U.S. Bureau of the Census

1880 Hidalgo County, Texas.

1900 Hidalgo County, Texas

U.S. Department of State

1903 Proceedings of the International (Water) Boundary Commission. United States and Mexico: Treaties of 1884 and 1889. Equitable Distribution of the Waters of the Rio Grande. Vol. 2. Government Printing Office,
Washington, D.C.

1913 Proceedings of the International Boundary Commission. United States and Mexico: American Section. Joint Report of the Consulting Engineers on Field Operations of 1910-1911. Supplemental Report of the American Consulting Engineer. Govemment Printing Office, Washington, D.C.

1929 Proceedings of the International Boundary Commission. United States and Mexico: Elimination of Bancos under Convention of March 20, 1905, Colorado River Nos. 501 and 502. Rio Grande Nos. 90 to 131, Inclusive. Map entitled "Roma to the Gulf of Mexico." Government Printing Office, Washington, D.C.

U.S. Department of the Interior, National Park Service, National Register Division

1982 How to Apply the National Register Criteria for Evaluation. Department of the Interior, Washington, D.C.

U.S. Fish and Wildlife Service

1980 Department of the Interior Habitat PreservationPlan-Preservation of Areas of Important Fish and Wildlife Habitat: Cameron, Hidalgo, Starr, and Willacy Counties, Texas. U.S. Fish and Wildlife Service, Region 2, Albuquerque.

U.S. 36th Congress, 1st Session

1860 House of Representatives Executive Document No. 81.

Vela, Edward C.

1993 Interview with Edward C. Vela, October 1, 1993, by Joe Graham.

Victor, Sally S.

1981 Historical Background. Appendix I in Cultural Resources Surveys and Assessments in Portions of Hidalgo and Willacy Counties, Texas, by D. William Day, Jane Laurens-Day, and Elton R. Prewitt, pp. 85-139. Reports of Investigations 15. Prewitt and Associates, Inc., Austin.

Vigness, David Martell

1946 The Lower Rio Grande Valley, 1836-1846. Unpublished Master's thesis, The University of Texas at Austin.

Vogt, Anton

1904 Burning an Up-Draft Kiln of Brick with Wood. Brick 20(4):176-178. 
Washington, Ann Reed

1983 Judge Juan Manuel de la Viña. Roots by the River: A Story of Texas Tropical Borderland, Vol. II, pp. 82-84. Border Kingdom Press, Mission, Texas.

Weddle, Robert S.

1992 Spanish Exploration of the Texas Coast, 15191800. Bulletin of the Texas Archeological Society 63:99-122.

Weir, Frank A.

1956 Surface Artifacts from La Perdida, Starr County, Texas. Bulletin of the Texas Archeological Society 27:59-78.

Willey, Gordon R, and Philip Phillips

1958 Method and Theory in American Archaeology. University of Chicago Press, Chicago.

Williams, Petra

1978 Staffordshire Romantic Transfer Patterns: Cup Plates and Early Victorian China. Fountain House East, Jeffersontown, Kentucky.

Flow Blue China: An Aid to Identification.
Fountain House East, Jeffersontown, Kentucky.

Williams, Petra, and Marguerite R. Weber

1986 Staffordshire II Romantic Transfer Patterns: Cup Plates and Early Victorian China. Fountain House East, Jeffersontown, Kentucky.

Wilson, Rex L.

1981 Bottles on the Western Frontier, edited by Edward Staski. The University of Arizona Press and Southwest Parks and Monuments Association, Tucson.

Winckler, S.

1976 Birds of Falcon, Starr County, Texas. In Rio Grande-Falcon Thorn Woodland, edited by D. Kennard. Natural Area Survey No. 13. Lyndon B. Johnson School of Public Affairs, The University of Texas at Austin.

Woodhead, E. J., C. Sullivan, and G. Gusset 1984 Lighting Devices in the National Reference Collection, Parks Canada. Studies in Archaeology, Architecture, and History. National Historic Parks and Sites Branch, Parks Canada, Ottawa, Ontario. 
APPENDIX A: Geomorphic Profile Descriptions

Karl W. Kibler 


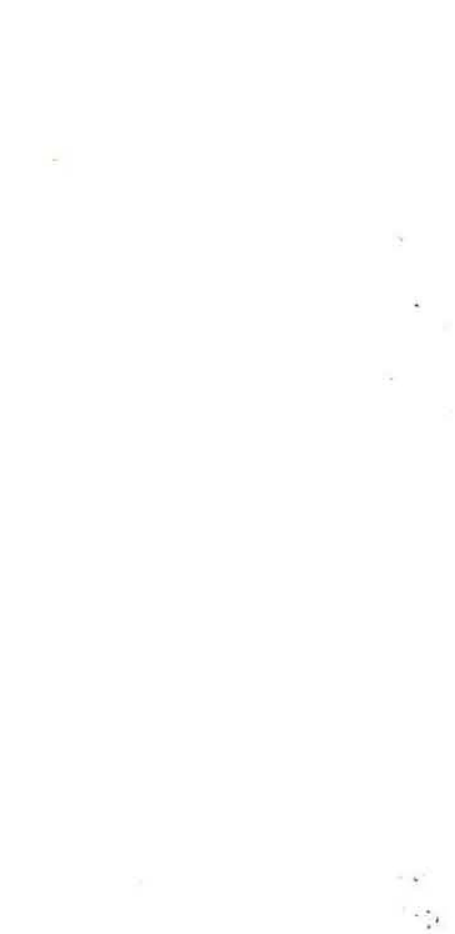


The geomorphic profiles are described and classified according to the procedures and criteria presented by Buol et al. (1980:21-43), Birkeland (1984), and Bettis (1984). The color (Munsell Soil Color Chart) and consistency (loose, very friable, friable, firm, very firm, and extremely firm) of a zone or sediment are recorded from a moist condition. Field definitions of texture consist of (1) sand (loose, single-grained, moist cast will crumble), (2) sandy loam (mostly sand with enough silt and clay to be somewhat coherent, individual sand grains are visible, moist cast bears careful handling), (3) loam (even mixture of sand, silt, and clay, gritty yet fairly smooth and slightly plastic, moist cast handles freely), (4) silt loam (predominantly silt with small amounts of fine sand and clay, moist cast bears heavy handling but will not ribbon), (5) clay loam (predominately clay with small amounts of fine sand and silt, moist ribbon breaks easily, moist cast bears heavy handling, slightly plastic, kneaded heavy compact mass will not crumble), and (6) clay (very plastic and sticky when wet, flexible ribbon). The terms sandy clay, sandy clay loam, loamy sand, silty clay, silty clay loam, and silt are used when the texture of a zone could not be placed into one of the above categories with confidence. The structure or soil aggregation of a zone or horizon is described by grade, size, and type. The grade is shown as weak, moderate, or strong. The size of the peds is shown as fine, medium, or coarse, depending on ped morphology or type. The type, referring to the shape of the peds, is identified as blocky (subangular and angular), platy, prismatic, columnar, or granular. Soil horizons not containing these characteristics are considered structureless. Final soil horizon classifications were made based on the terminology and criteria presented by Birkeland (1984) and Bettis (1984).

In the absence of soil formation, the sedimentary structures of a zone are presented. Types of sedimentary structures include, but are not limited to, planar laminations, graded beds, crossstratifications, trough cross-stratifications, ripples, climbing ripples, and massive structures.

Mottles are described by color, abundance, contrast, and size. Abundance is shown as few $(<2 \%)$, common $(2 \%-20 \%)$, and many $(>20 \%)$, while contrast is described as faint, distinct, or prominent. Size ranges are given as fine $(<0.5 \mathrm{~cm})$, medium $(0.5-1.5 \mathrm{~cm})$, or coarse $(>1.5 \mathrm{~cm})$. Terms pertaining to abundance are also used to describe the occurrence of inclusions or intrusive objects, such as gravels and charcoal. The lower boundary of each zone or horizon is described in terms of distinctiveness - very abrupt $(<0.1 \mathrm{~cm})$, abrupt $(0.1-2.5 \mathrm{~cm})$, clear $(2.5-6.4 \mathrm{~cm})$, gradual $(6.4-12.7 \mathrm{~cm})$, and diffused $(>12.7 \mathrm{~cm})$ — and topography — smooth, wavy, irregular, and broken. 
Zone Depth (cm) Description

SITE $41 \mathrm{HG} 153$

Blade Cut Adjacent to Features 3 and 4; North Wall

$1 \quad 0-24$

Dark grayish brown (10YR 4/2) clay loam, firm, massive, few pieces of charcoal, few snail shells, common historic debris (i.e., glass and ceramic fragments), common roots and rootlets, very abrupt to abrupt wavy lower boundary, $\mathrm{Cu}$ horizon.

$2 \quad 24-31$

Brown to dark brown (10YR 4/3) sandy clay, friable, moderate fine subangular blocky structure, few small $\mathrm{CaCO}_{3}$ nodules, common historic debris (i.e., glass and ceramic fragments), abrupt wavy lower boundary, $\mathrm{Cu}$ horizon.

$3 \quad 31-43+$

Grayish brown to dark grayish brown (10YR 5/2 to 10YR 4/2) clay, firm, moderate medium blocky structure, few rootlets, common snail shells, common $\mathrm{CaCO}_{3}$ filaments, lower boundary not obsęrved, $2 \mathrm{Ab}$ horizon.

Backhoe Trench 1993-1, Locality A, East Wall

$1 \quad 0-24$

Dark grayish brown (10YR 4/2) clay, firm, massive to planar laminated structures, many roots and rootlets, common pieces of charcoal and charcoal flecks, common humic materials, few snail shells, few historic artifacts (i.e., glass and ceramic fragments), abrupt wavy lower boundary, $\mathrm{Cu}$ horizon.

$24-106+$

Grayish brown (10YR 5/2) clay, firm, moderate medium blocky structure, common small incipient $\mathrm{CaCO}_{3}$ nodules, few rootlets, common humic materials, few snail shells, lower boundary not observed, 2Ab horizon.

Backhoe Trench 1993-1, Locality B, East Wall

$1 \quad 0-40$

Dark grayish brown (10YR 4/2) clay, firm, massive to planar-laminated structures, many roots and rootlets, common pieces of charcoal and charcoal flecks, common humic materials, few snail shells, few historic artifacts (i.e., glass and ceramic fragments), abrupt wavy lower boundary, $\mathrm{Cu}$ horizon.

$2 \quad 40-60$

Brown (10YR 5/3) very fine sand, very friable, massive, common roots and rootlets, common insect burrows, few humic materials, very abrupt wavy lower boundary, $\mathrm{Cu}$ horizon.

$3 \quad 60-101$

Brown (10YR 5/3) sandy clay, friable, moderate medium blocky structure, common roots and rootlets, a single burned tree stump, common small incipient $\mathrm{CaCO}_{3}$ nodules, few humic materials, common snail shell fragments, abrupt wavy lower boundary, $2 \mathrm{ACk}$ horizon.

$4 \quad 101-157$

Brown (10YR 5/3) cross-stratified fine sand, very friable, few roots and rootlets, few humic materials, lower boundary not observed, $2 \mathrm{C}$ horizon. 


\section{Zone Depth $(\mathrm{cm}) \quad$ Description}

5 157-173+ Grayish brown (10YR 5/2) clay, firm, moderate medium blocky structure, common small incipient $\mathrm{CaCO}_{3}$ nodules, few rootlets, common humic materials, few snail shells, lower boundary not observed, equivalent to Zone 2 of Locality A, $3 \mathrm{Ab}$ horizon.

Backhoe Trench 1993-4, East Wall

$1 \quad 0-25$

Brown (10YR 5/3) clay, firm, massive, common roots, common humic materials, few insect burrows, abrupt wavy lower boundary, $\mathrm{Cu}$ horizon.

$2 \quad 25-87$

Brown to dark brown (10YR 4/3) clay, firm, weak coarse granular structure, many distinct fine yellowish brown (10YR 5/4) mottles, few snail shells, common rootlets, common humic materials, gradual smooth lower boundary, $2 \mathrm{AC}$ horizon.

$3 \quad 87-111+$

Brown (10YR 5/3) clay, firm to very firm, strong medium blocky structure, few slickensides on ped faces, many distinct fine yellowish brown (10YR 5/4) mottlès, common small $\mathrm{CaCO}_{3}$ nodules, common humic materials, common snail shells, lower boundary not observed, $2 \mathrm{Ck}$ horizon.

\section{Backhoe Trench 1993-5. East Wall}

$1 \quad 0-29$

Dark grayish brown (10YR 4/2) clay loam, friable, massive, many roots and rootlets, few snail shells, few pieces of charcoal, abrupt wavy lower boundary, $\mathrm{Cu}$ horizon.

$29-107$

Brown to dark brown (10YR 4/3) clay, firm, strong medium blocky structure, common rootlets, few humic materials, few small incipient $\mathrm{CaCO}_{3}$ nodules, gradual smooth lower boundary, 2AC horizon.

$3 \quad 107-182+$

Brown (10YR 5/3) clay, very firm, strong medium blocky structure, few slickensides on ped faces, few distinct fine yellowish brown (10YR 5/6) mottles, many $\mathrm{CaCO}_{3}$ nodules, few rootlets, few humic materials, few snail shells, lower boundary not observed, $2 \mathrm{Ck}$ horizon.

\section{Backhoe Trench 1994-4, West End}

$1 \quad 0-42$

Dark grayish brown (10YR 4/2) clay loam, firm, moderate medium subangular blocky structure, common snaíl shell fragments, common rootlets, clear smooth lower boundary, Ap horizon.

$2 \quad 42-93$

Grayish brown (10YR 5/2) clay loam, friable, moderate medium subangular blocky structure, common distinct coarse mottles of lighter hues than surrounding matrix, common snail shell fragments, few rootlets,. common insect burrows, clear smooth lower boundary, A horizon.

$3 \quad 93-134+$

Brown to dark brown (10YR 4/3) clay, firm, moderate medium subangular blocky structure, few rootlets, few humic materials, few very small incipient $\mathrm{CaCO}_{3}$ nodules, common snail shells, few slickensides on ped faces, lower boundary not observed, Ck horizon. 
Zone Depth (cm) Description

Backhoe Trench 1994-5, South Wall

$1 \quad 0-39$

Dark grayish brown (10YR 4/2) silty clay loam, friable, moderate medium subangular blocky structure, common roots, snail shell fragments, very abrupt smooth lower boundary, Ap horizon.

$2 \quad 39-57 / 78$

Brown (10YR 5/3) silt loam, very friable, weak fine subangular blocky structure, common illuvial clays, few $\mathrm{CaCO}_{3}$ filaments, few charcoal flecks, few snail shell fragments, abrupt to clear wavy lower boundary, Cu horizon.

$3 \quad 57 / 78-108$

Dark grayish brown (10YR 4/2) clay loam, firm, moderate medium subangular blocky structure, common snail shell fragments, common $\mathrm{CaCO}_{3}$ filaments, few humic materials, few slickensides on ped faces, clear smooth lower boundary, $2 \mathrm{Ab}$ horizon.

$4 \quad 108-145+$

Brown (10YR 5/3) clay, firm, strong medium subangular blocky structure, few humic materials, few snail shell fragments, common very small incipient $\mathrm{CaCO}_{3}$ nodules, few slickensides on ped faces, lower boundary not observed, $2 \mathrm{Ck}$ horizon.

Backhoe Trench 1994-6, South Wall

$1 \quad 0-47$

$2 \quad 47-61 / 72$

Dark grayish brown (10YR 4/2) clay loam, friable, moderate medium subangular blocky structure, common roots, common organic debris, few snail shell fragments, few charcoal flecks, one transfer-printed ceramic sherd, abrupt smooth lower boundary, Ap horizon.

Brown to dark brown (10YR 4/3) silt loam, very friable, weak fine angular blocky structure, few snail shell fragments, few charcoal flecks, common illuvial clays, abrupt to clear wavy lower boundary, $\mathrm{Cu}$ horizon.

$3 \quad 61 / 72-113+$

Dark grayish brown (10YR 4/2) to grayish brown (10YR 5/2) clay loam, firm, moderate medium subangular blocky structure, common snail shell fragments, few rootlets, few slickensides on ped faces, lower boundary not observed, 2Ab horizon.

\section{SITE $41 \mathrm{HG} 158$}

Backhoe Trench 1, North Wall

$1 \quad 0-45$

Grayish brown (10YR 5/2) clay, firm, massive, common historic debris (i.e., glass, ceramic, and brick fragments), common rootlets, common snail shells, few pieces of charcoal, clear wavy lower boundary, $\mathrm{Cu}$ horizon.

$2 \quad 45-77$

Dark grayish brown (10YR 4/2) clay loam, friable, weak fine blocky structure, many historic artifacts (i.e., brick, glass, and ceramic fragments), many pieces of charcoal, abrupt wavy lower boundary, $\mathrm{Cu}$ horizon. Feature 1 is at $50-60 \mathrm{~cm}$ within Zone 2. 


\begin{abstract}
Zone Depth (cm) Description
$3 \quad$ 77-108+ Brown (10YR 5/3) clay, firm, moderate fine blocky structure, common snail shells, common $\mathrm{CaCO}_{3}$ filaments, few rootlets, lower boundary not observed, 2Abk horizon.

\section{Backhoe Trench 4, North Wall}

1

$0-15$

Dark grayish brown (10YR 4/2) clay, friable, massive, few rootlets, common historic debris (i.e., ceramic, glass, and brick fragments), abrupt wavy lower boundary, $\mathrm{Cu}$ horizon.

$2 \quad 15-31$

Dark grayish brown (10YR 4/2) silty clay loam, friable, weak medium granular structure, common rootlets, few historic artifacts (i.e., ceramic, glass, and brick fragments), few charcoal flecks, abrupt smooth lower boundary, $\mathrm{Cu}$ horizon.

$3 \quad 31-72$

Brown (10YR 5/3) silty clay loam, friable, moderate fine blocky structure, few snail shells, many historic artifacts (i.e., brick, ceramic, and glass fragments), common charcoal flecks, few $\mathrm{CaCO}_{3}$ filaments, clear smooth lower boundary, $\mathrm{Cu}$ horizon.

$4 \quad 72-96+$

Brown to dark brown (10YR 4/3) clay loam, friable to firm, moderate fine blocky structure, few $\mathrm{CaCO}_{3}$ nodules, few snail shells, few charcoal flecks, lower boundary not observed, 2Abk horizon.
\end{abstract}

\title{
REFERENCES CITED
}

Bettis, E. Arthur, III

1904 New Conventions for the Designation of Soil Horizons and Layers. Plains Anthropologist 29(103):57-59.

Birkeland, Peter W.

1984 Soils and Geomorphology. Oxford University Press, Oxford.
Buol, S. W., F. D. Hole, and R. J. McCracken

1980 Soil Genesis and Classification. 2nd ed. Iowa State University Press, Ames. 


\section{APPENDIX B: Summary and Description of Brick Types Associated with Dump Features at 41 HG156}

Douglas K. Boyd 


\section{INTRODUCTION}

Bricks are the dominant artifact type at 41 HG156, and they are the only type of artifact that was collected. Aside from the three types of bricks that were made on-site (which are described in Chapter 6), 30 different types of bricks were observed in features that are interpreted as dump piles. After examining all of the dump features, each distinctive type of brick was described in the field and the best representative example(s) of each type was collected (see Table 20). Based mainly on the collected specimens, but supplemented by the field observations, each of the 30 brick types is described in this appendix. The author appreciates the assistance of architect Robert Steinbomer, who freely shared his extensive knowledge of bricks and brickmaking.

This appendix consists of three sections. The first explains the terminology relating to brick manufacturing processes and diagnostic attributes that are useful for classifying and identifying bricks. The second section presents type descriptions for the 30 brick types (i.e., Types 4-32, including Types $10 \mathrm{a}$ and $10 \mathrm{~b}$ ) represented at $41 \mathrm{HG} 156$. The final section is a brief summary and discussion of the bricks found in the dump features.

\section{BRICK MANUFACTURING TERMINOLOGY AND ATTRIBUTES}

The information provided in this section is largely derived from and is consistent with the brick manufacturing and descriptive terminology used by Gurcke (1987) and Steinbomer (1980). This is not intended to be a comprehensive list of brickmaking terminology or a complete discussion of brickmaking technology (for such detailed information, see Gurcke 1987). Rather, this brief discussion is intended to serve as a summary of the terminology and methods used to describe the brick types represented at 41HG156. The discussion is divided into three broad categories: descriptive attributes, manufacturing processes and attributes, and identifying markings. Several illustrations are provided in Figure 60 to facilitate understanding the terminology used in the brick type descriptions.

\section{Descriptive Attributes}

The descriptive attributes include measurements of length, width, thickness, and weight. Length, width, and thickness measurements were made only on collected specimens and are given to the nearest millimeter. All measurements represent complete dimensions except when they are followed by a plus (+), which indicates a partial measurement representing the maximum dimension for the collected fragment(s). In cases where a single measurement is presented, it represents the exact dimension of one specimen or indicates that all of the collected specimens are the same size. In a few cases, two or more fragmentary specimens were used to estimate the dimension of a complete specimen but these dimensions are followed by a notation that they are estimated. Because bricks, especially handmade ones, can vary considerably in size, a range is sometimes given. It may represent variability within a single specimen or within several specimens. Weight, given to the nearest gram, refers to the weight of a complete or nearly complete specimen only. A range of weights indicates variation between two or more specimens of the same type.

Matrix attributes refer to observations related to the clay matrix of the brick (i.e., color, texture, inclusions, and hardness), and when possible all matrix observations were made on a broken surface or edge. Matrix attributes relate to the interior rather than the surface of the brick. These observations were made only on collected specimens except as otherwise noted. Matrix colors are described by broad terms indicating approximate colors. Precise color is not an important variable in most cases because there are many different variables that can greatly alter the color of a brick (e.g., minor variations in composition or firing temperature). For soft-mud and stiff-mud bricks, the colors are given as either buff or salmon. Buff refers to very pale brown to yellow colors (i.e., 10YR $8 / 3$ to $8 / 6$ and 10 YR $7 / 3$ to $7 / 6$ ) and salmon refers to reddish brown to yellowish red colors (i.e., 5YR 5/4 to 5/8). The term salmon has been used to refer to poorly fired bricks that are very soft, but this meaning is not implied when the term is used in this appendix.

Bricks that were manufactured in a fully 


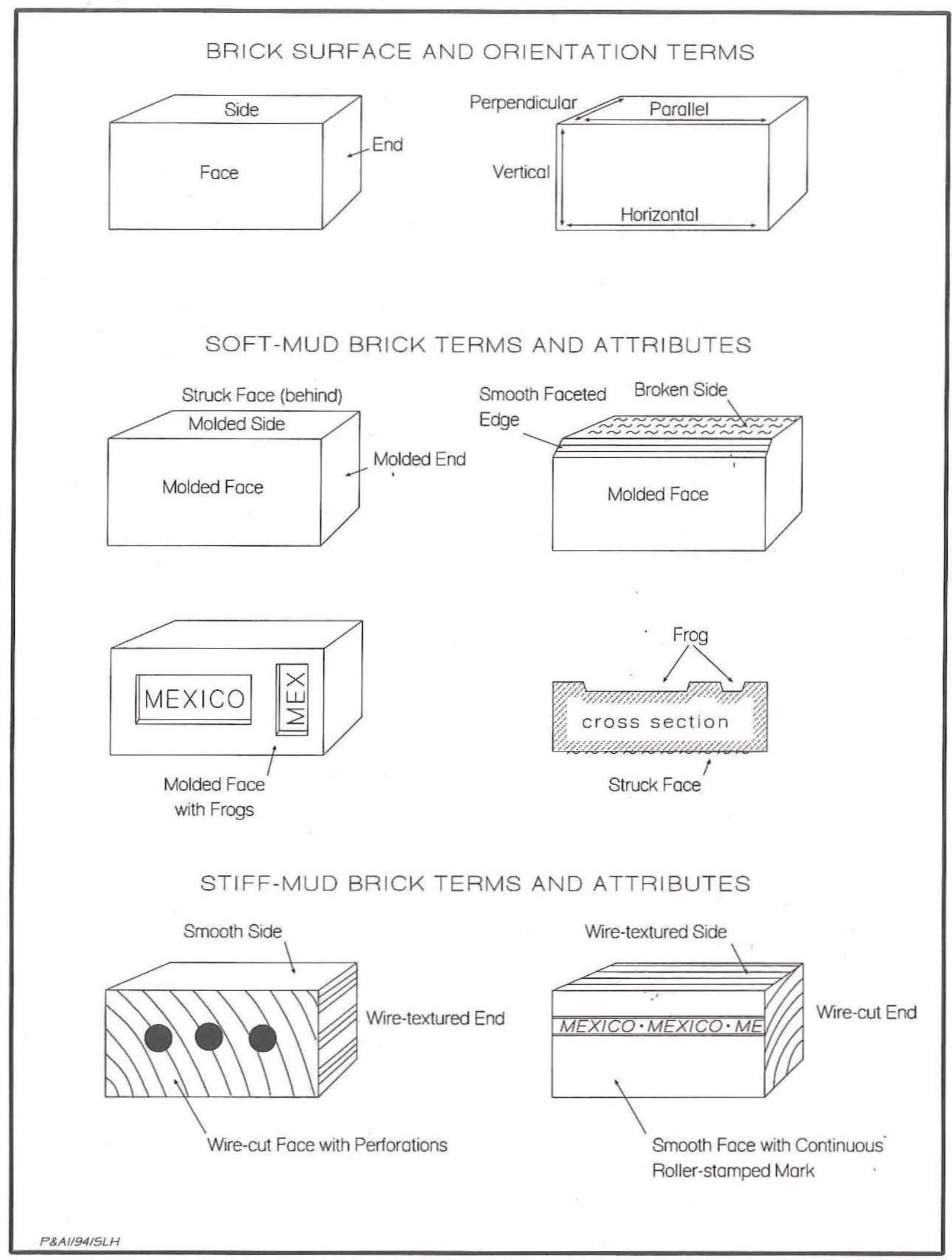

Figure 60. Illustrations of brick terminology and attributes. 
automated process, however, exhibit much more uniform colors because of the greater control over the composition and firing temperature. Hence, color is a more important descriptive attribute for some machinemade (i.e., dry-pressed) bricks. For these specimens, precise colors are designated using a Munsell Soil Color Chart.

Texture refers to the look and feel of the brick clay, and inclusions refers to any objects (whether incidental or intentionally added as a tempering agent) that are larger than the surrounding clay matrix. These observations are not quantified in any rigorous manner but are subjective assessments of the brick's matrix, as characterized by the sizes and identification of its components. Terms similar to those used by geomorphologists to describe sediment textures and inclusions are used. Terms describing texture (e.g., clay, fine sandy, medium sandy) refer to the size of the individual grains that dominate the brick's matrix. The relative amount of pores (i.e., open spaces in the brick's matrix resulting from poor compaction) is also noted in the texture description. Inclusions are identified when possible, and their relative abundance is noted (e.g., few, common, abundant). Unusual inclusions observed in noncollected specimens (i.e., noted in the field observations) of a particular brick type also are mentioned.

The final matrix attribute that is recorded is that of hardness. The hardness of the brick's clay matrix is given relative to Mohs' scale of hardness and was determined using a mineral test set.

\section{Manufacturing Processes and Attributes}

Bricks generally are made by one of three processes: soft mud, stiff mud, and dry pressed. These terms refer to variations in the amount of water in the clay matrix at the time the bricks are molded and to the molding process that is used. Soft mud refers to the process used to mold clays that have $20 \%-30 \%$ water content. Stiff mud refers to the process used to mold clays that have $12 \%-15 \%$ water content. Dry pressed refers to the process used to mold clays that have $10 \%$ or less water content. Each of these processes results in a number of distinctive attributes that are important for identifying and describing bricks.

\section{Soft-mud Bricks}

Soft-mud bricks can be made entirely by hand or by using some type of soft-mud brick machine. Machinemade soft-mud bricks can exhibit many of the same characteristics as those that are handmade, particularly if they were molded on an early machine but were still struck by hand. Handmade soft-mud bricks, however, frequently have distinctive attributes that their machinemade counterparts do not. All of the soft-mud bricks in the 41HG156 sample exhibit crude, sloppy struck faces that distinguish them as being hand struck. Since there is no evidence that any of them were made by soft-mud brick machines, the remainder of this discussion refers only to handmade softmud bricks.

The process of hand molding soft-mud bricks results in distinctive manufacturing marks and attributes. Brick clays could be mixed by hand or in various types of pug mill mixers, but the latter generally produce a more evenly mixed clay while hand-mixed clays tend to have more inclusions and higher porosity. After the proper moisture content and mixing was achieved, the clay was then thrown by hand into the brick mold. Molding was done by throwing a glob of wet clay into the mold and pressing it in or compacting it to fill all the corners of the mold. Brick molds usually were made of wood and could contain compartments for three to five individual bricks. When the mold was completely filled with clay, the excess clay was removed from the top by striking the surface. Striking, or scraping the extra clay off the top of the mold, was done by hand with a striking tool, usually with a wooden board or stick, a metal blade, or a wire bow. The resulting texture of the struck face is generally quite rough, and it is an important characteristic of hand-molded and handstruck bricks. Quite often there are deep, sometimes parallel, lines caused by inclusions being dragged across the surface by the striking tool.

The face opposite the struck face is called the molded face since it was on the bottom of the mold. The molded face is smooth, as are the sides and ends of hand-molded soft-mud bricks, since these surfaces were in contact with the mold. In order to allow the bricks to slip freely from the mold, it had to be lubricated. This generally was 
done with water or sand, the latter being the most common method used in the the Lower Rio Grande Valley. The resulting bricks are called sand struck and generally have a sandy texture on the molded face, sides, and ends. Water-struck bricks generally have a smoother texture and often exhibit small ripples on the molded surfaces, but none of these characteristics were noted in the 41HG156 sample. The struck face could also be lubricated to allow for a smoother strike, again with either water or sand. The same lubricant usually was used for the mold and the strike, but it is possible for a combination of these techniques to be used for lubricating the mold and the strike (i.e., a sand-struck brick with a water-struck face).

Another feature of soft-mud bricks is that they tend to have rounded corners or edges since they are softer and more porous due to poor compaction and firing at relatively low temperatures. Since they are softer, the corners and edges tend to be damaged or eroded more easily. While not absolutely diagnostic, edge roundness is an attribute that can help distinguish soft-mud bricks.

Another common feature found on soft-mud bricks is a frog (see Gurcke 1987:Figure 33). Frogs occasionally are found on dry-pressed bricks, but the frogs on soft-mud bricks are distinct from their dry-pressed counterparts. Frogs are indentations on the molded face formed by attaching a small wooden block, called a kick, onto the bottom of the mold. While they can be any shape, frogs most commonly are rectangular, and they can have straight (i.e., perpendicular to the face plane) or faceted (i.e., inward sloping) sides. Frogs are a useful feature because they reduce slightly the amount of clay needed for each brick and they provide a key for the mortar, resulting in a stronger wall construction. Frogs may be plain or they may have identifying names appearing in them, either as impressed letters (caused by raised letters on the mold kick) or raised letters (caused by letters carved or burned into the mold kick). Often the detailed characteristics of the names inside frogs can provide clues to the manufacturing process (see Identifying Markings below). Detailed measurements (i.e., length, width, and depth) and diagnostic characteristics (i.e., shape, orientation, and location) of each frog are presented in the brick type descriptions.

One special type of hand-molded soft-mud brick noted in the $41 \mathrm{HG} 156$ sample is a split-face brick. These bricks have most of the same attributes as other hand-molded soft-mud bricks, but they also have a distinctive, very rough textured side that was intended to be ornamental and mimic the look of rock. Two of these bricks were molded and fired in a joined pair but subsequently were broken into two bricks, each having a rough broken side. In order to facilitate breaking into two bricks, one or both of the common edges were faceted during the molding process. The molded face would have a shallow transverse cut created by a ridge along the bottom of the mold, and a similar transverse cut could be made on the top after the striking was done. All of the split-face bricks in the 41HG156 sample have either a top or bottom faceted edge on the broken side.

In summary, soft-mud handmade bricks in the 41 HG156 sample can be characterized as having (1) softer and more-porous matrix as a result of the clays having been poorly mixed and fired at relatively low temperatures, (2) rounded corners and edges, (3) smooth but sandy molded surfaces, and (4) a rough struck face, often with distinctive drag marks indicating the direction of the strike. They also frequently have frogs, with or without identifying markings, and the split-face brick is a common form.

\section{Stiff-mud Bricks}

Stiff-mud bricks may be produced by a partially or fully automated process. They are molded by a special machine (or combination of machines) that mixes the clay and water in a pug mill, forms and extrudes a continuous square or rectangular column of clay that passes onto a cutting table, and subsequently cuts the column into individual brick units using piano wire mechanisms. Hence, this method is also called the extruded or wire-cut process, and bricks produced in this manner have many diagnostic attributes.

Stiff-mud bricks usually exhibit very distinctive wire cut marks on opposite faces, sides, or ends (see Gurcke 1987:Figures 31 and 32). Wire cuts are somewhat similar to struck faces of soft-mud bricks but are much more uniform. They generally have fine parallel lines where inclusions and/or clay particles were dragged by the cutting wire. On any brick surface, the wire cuts may be horizontal, vertical, or arc shaped, depending upon 
the nature of the cutting machine. Wire cut marks can be partially obliterated by subsequent modifications (such as compaction in a repress machine which produces smooth surfaces similar to those of dry-pressed bricks), but they seldom are totally obliterated and such modifications are not represented in the $41 \mathrm{HG} 156$ sample.

Perforations and surface texture are two additional attributes that commonly are found on, and are diagnostic of, stiff-mud bricks (see Gurcke 1978:Figure 29). Perforations are holes entirely through the face of a brick, and they are easily made on stiff-mud machines (they can be made on dry-pressed bricks, but this is rare). Holes through the brick serve the same basic purpose as do frogs in that they cut down the amount of clay needed per brick and they serve as keys for mortar during construction. They also allow heat to pass through during firing, and a perforated brick is usually much more uniformly fired than a nonperforated brick.

Many different types of surface texture could be added to the column of clay as it was extruded from a stiff-mud brick machine, but the only type noted in the 41HG156 sample is wire texture. Wire texture appears as a series of parallel etched lines, obviously done while the clay was still slightly wet, on one or more surfaces of the brick. It was added to the bricks, usually on the sides or ends, by nails or wires attached to the die or mouthpiece as the clay column was extruded (see Gurcke 1987:Figure 29a).

Another attribute found on several stiff-mud bricks in the 41HG156 sample is that the identifying marks were made by a continuous roller stamp. These impressed labels were applied to the edge of the column of clay as it was extruded by a roller that continuously repeated the mark. In some cases, the label repeats itself across a single brick surface, from one edge to another, and obviously was truncated by the wire cuts.

\section{Dry-pressed Bricks}

The final method of brick manufacturing, that of dry-pressing bricks, can be done only by machine. The process begins by grinding the nearly dry clay to a fine powder and adding grog of various sizes. Then the mixture is put into the pressing machine where individual steel brick molds are filled and compacted under high pressure (i.e., 500 psi or higher). When fired, the resulting bricks have very distinctive smooth surfaces and sharp edges. They also have a distinctive composition and grainy appearance because of the use of moderate to high amounts of nonplastic grog. As with soft-mud bricks, dry-pressed bricks can have frogs and/or labels impressed during the molding process.

\section{Identifying Markings}

Bricks may be marked with a variety of different symbols or names for a variety of different purposes, but there is only one way in which the marks can be produced. All brick marks are stamped into the brick; although this usually occurs during the molding process, marks also can be added to soft-mud bricks after they have been molded and laid out to dry. The stamping can result in symbols or names that are impressed into the brick surface or are in relief (e.g., raised letters). The marks can be made either on a smooth molded face or, as is most commonly done with soft-mud bricks, inside a frog.

In the 41HG156 brick sample, the most common type of markings denote the country of origin, the specific place of manufacture, the name of the manufacturer, and/or the name of the specific product. These markings are discussed in more detail later (see Summary and Discussion), but there are certain characteristics that are considered important for describing bricks. For each brick type, any identifying marks are listed separately, followed by a type classification of each mark. A measurement of letter height refers to the exact height, from top to bottom, of individual letters. For very uniform marks, the letter height is consistent for all letters and only one measurement is given. Conversely, the individual letters of some of the hand-molded bricks may vary considerably in size, in which case a range of letter heights is given. Other observations regarding identifying marks include their location and orientation (relative to the brick's molded face and/or any frogs) and a description of the uniformity of the mark. Measurements of the depth of impressed letters or height of raised letters also are given. As with the letter height measurement, a single measurement for impressed depth or raised height is given for consistent markings while a range may be given for irregular 
markings on hand-molded bricks.

\section{BRICK TYPE DESCRIPTIONS}

The 30 types of bricks represented in the dump features at 41 HG156 are described individually below (see Table 22 for a list of brick types observed in and collected from various features). These descriptions are taken largely from the collected specimens but also include general observations made in the field. Photographs of specimens representing each of these types are presented in Figures 61-65.

\section{Brick Type 4}

Collected Specimens: 2 fragments from Feature 8A

\section{Measurements:}

Length: $193 \mathrm{~mm}$

Width: $95 \mathrm{~mm}$ (estimated)

Thickness: $58 \mathrm{~mm}$

\section{Matrix Attributes:}

Color: Red (10R 5/6)

Texture: Very fine clay with abundant coarse inclusions

Inclusions: Large yellow angular rock or grog fragments

Hardness: $7-8$

Manufacturing Process: Stiff mud

Manufacturing Attributes: Wire cuts on both faces and on both ends; 3 circular holes, 34-mm diameter; sharp comers and edges

Identifying Markings: None

Other Attributes/Comments: Fragments have concrete mortar adhering to them; very well made, probably a modern brick made in the U.S.

\section{Brick Type 5}

Collected Specimens: 1 cut fragment from Feature 8A

Measurements:

Length: $280+\mathrm{mm}$ (one end is cut)

Width: $130 \mathrm{~mm}$

Thickness: $50+\mathrm{mm}$ (one end is cut)
Matrix Attributes:

Color: Pale yellow (2.5Y 8/4)

Texture: Very fine

Inclusions: None observed

Hardness: 7-8

Manufacturing Process: Dry pressed

Manufacturing Attributes: Sharp comers and edges; fluted sides and faces on both interior and exterior

Identifying Markings:

Mark: "IN-STD-SANI-FINISH-EL"

Type: Manufacturer/product name-Elgin Standard Sani-Finish

Letter Height: $10 \mathrm{~mm}$

Description: Very uniform mark, shallow (less than $0.5 \mathrm{~mm}$ deep) impressed letters, continuous roller stamped continuing off both ends of brick

Location: Horizontal along one flute ridge on one side only

Identification: Since Type 5 is a structural tile, it does not match any of the bricks illustrated by Steinbomer (1980), but it is probably a product of one of the Elgin brick companies of Bastrop County, Texas. Steinbomer's (1980) "Texas Brick Manufacturers: A Catalogue" lists the following Elgin companies under Bastrop County: Elgin Standard Brick Company, Elgin-Standard Brick Manufacturing Company, Elgin-Butler Brick Company, Elgin-Butler Brick and Tile Company, Elgin Brick and Tile Company, and the Elgin Press Brick Company.

Other Attributes/Comments: Type 5 specimens are actually structural clay tiles rather than bricks. All observed complete specimens appear to be hollow rectangular tubes with open ends. They are 130 $\mathrm{mm}$ wide and $95 \mathrm{~mm}$ thick but generally are cut to various lengths. Observed specimens frequently are glazed with yellow or white on one face. Concrete mortar is adhering to the collected and observed specimens.

\section{Brick Type 6}

Collected Specimens: 1 complete brick from Feature $8 \mathrm{~F}$ 


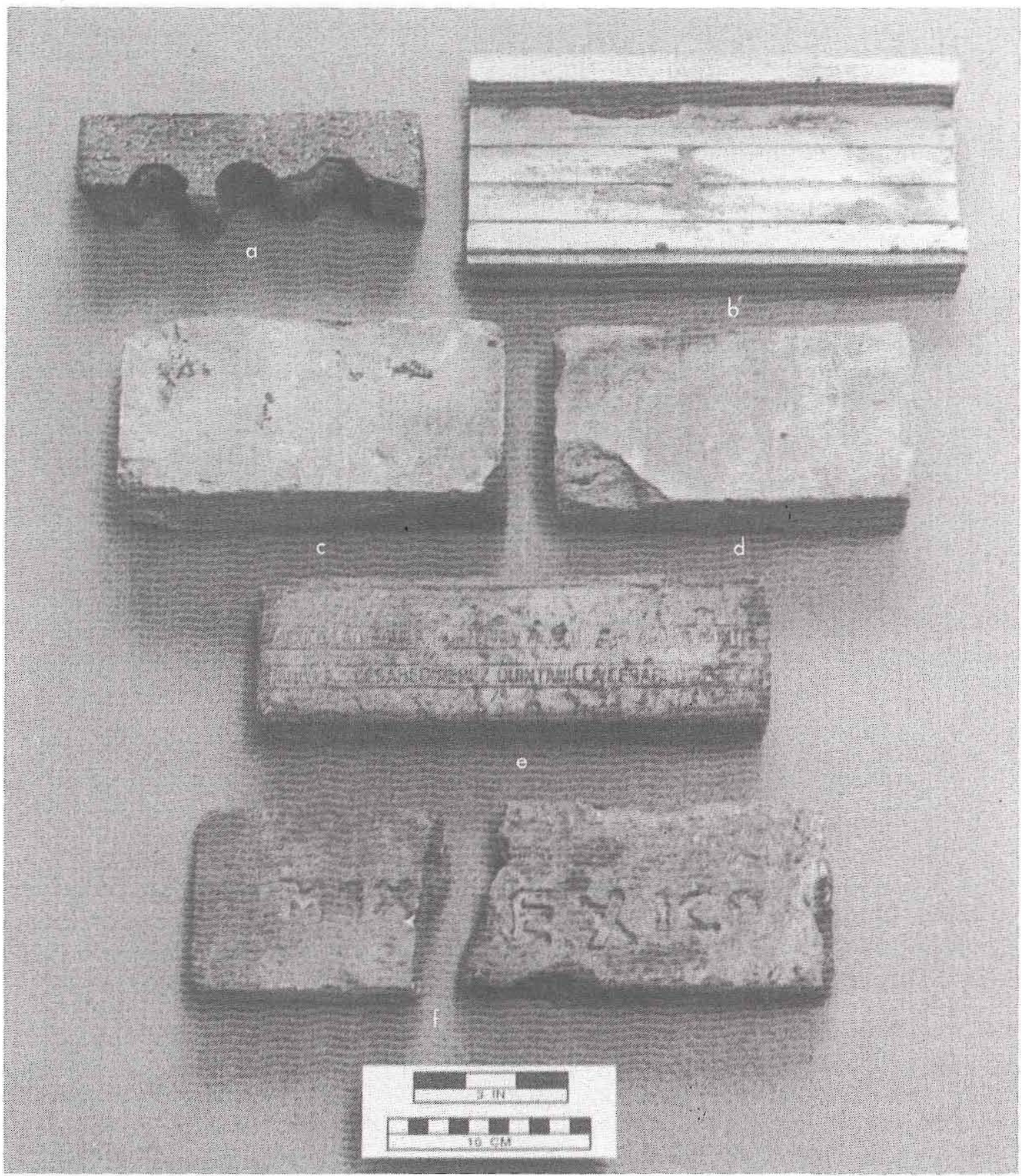

Figure 61. Brick Types 4-9. 
Pharr-Reynosa International Bridge, Hidalgo County, Texas

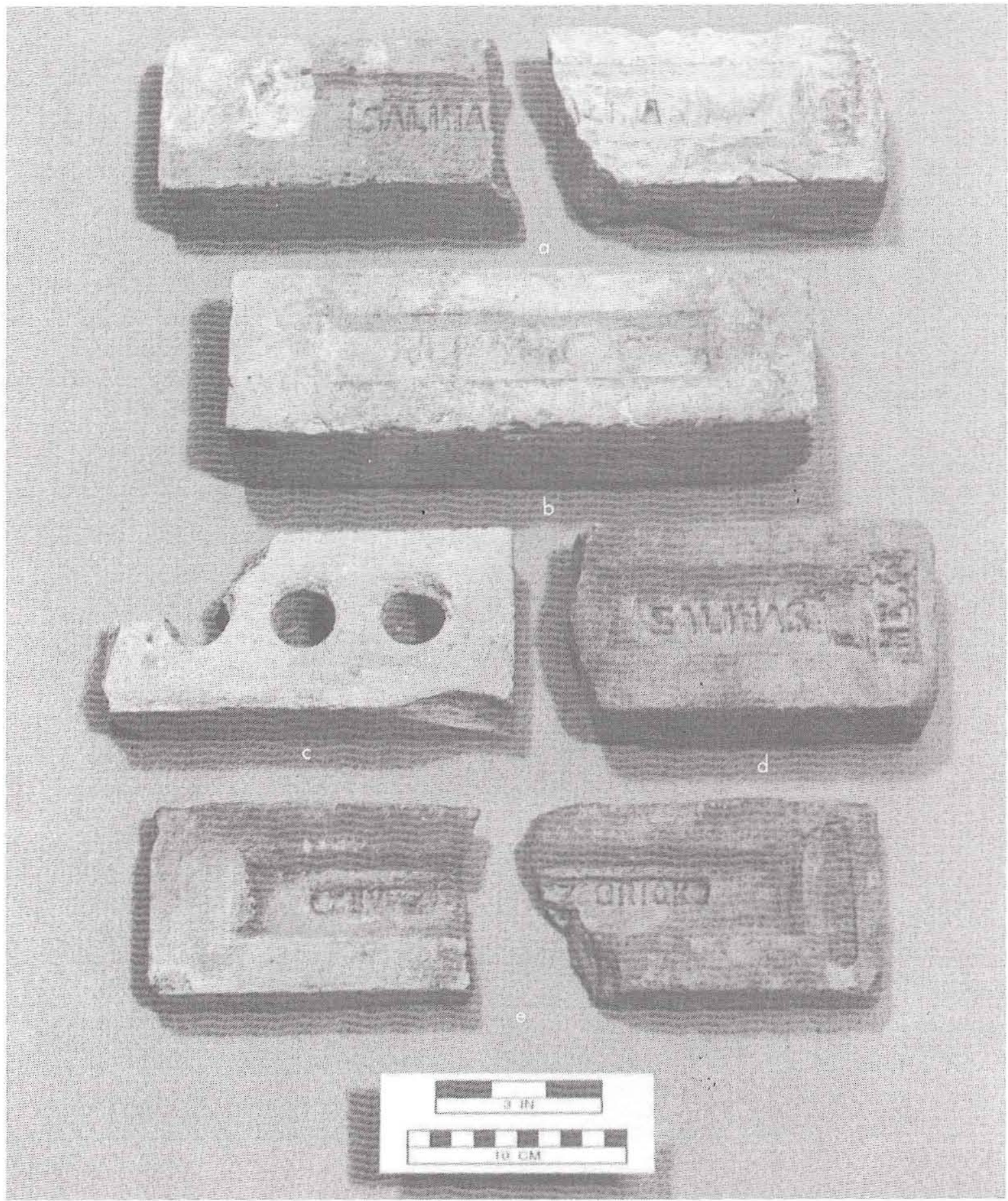

Figure 62. Brick Types 10-14. 


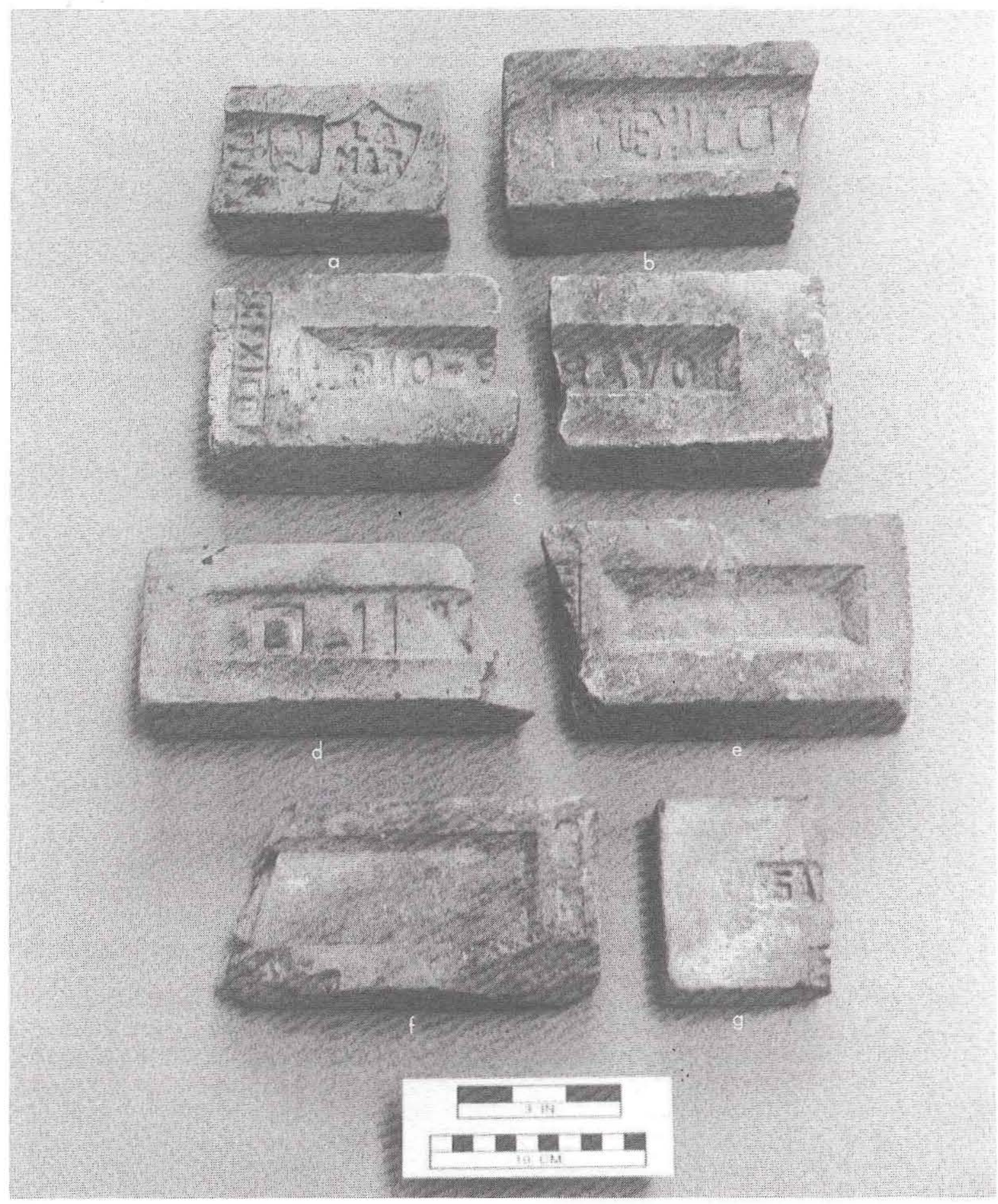

Figure 63. Brick Types 15-21. 
Pharr-Reynosa International Bridge, Hidalgo County, Texas

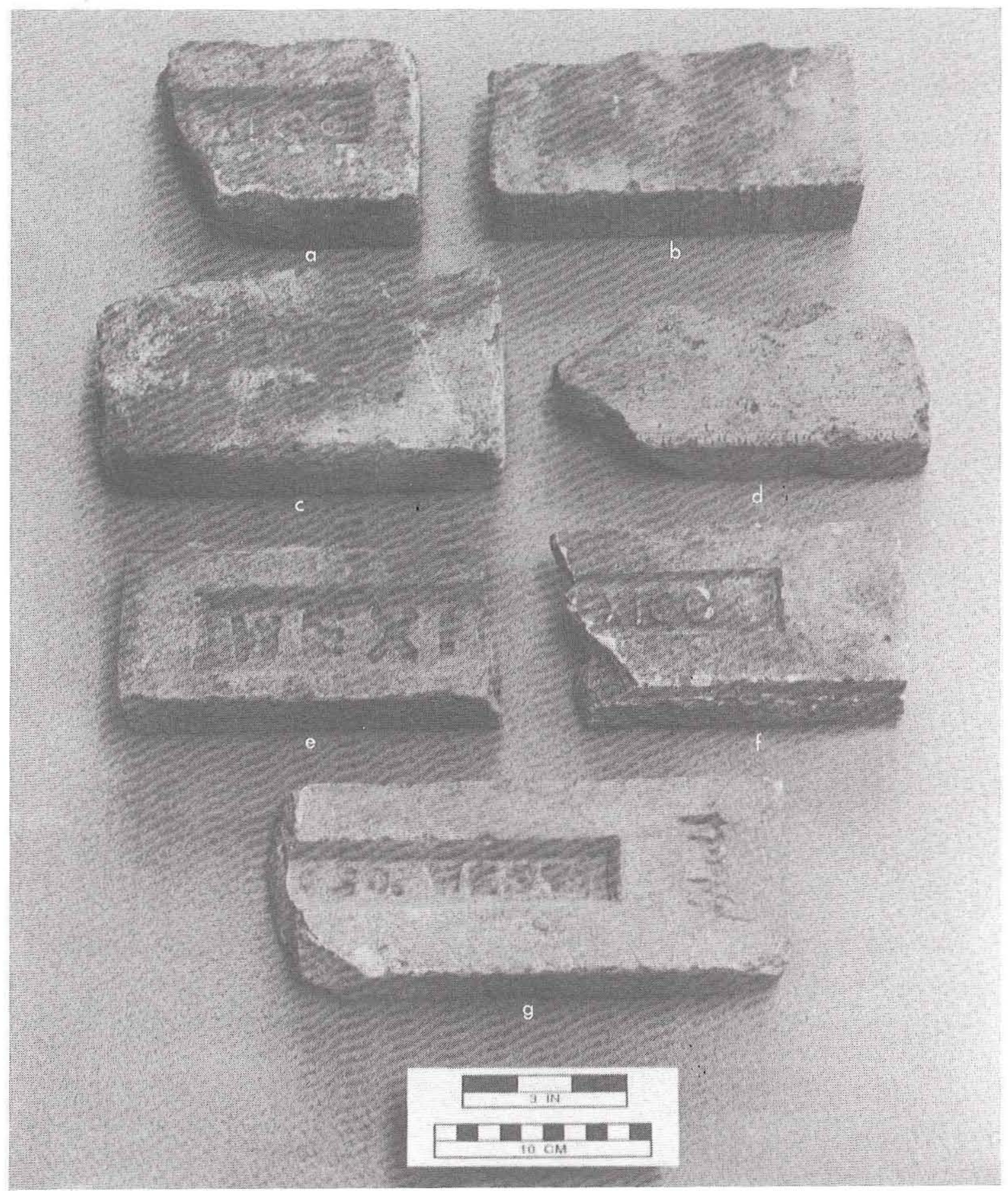

Figure 64. Brick Types 22-28. 


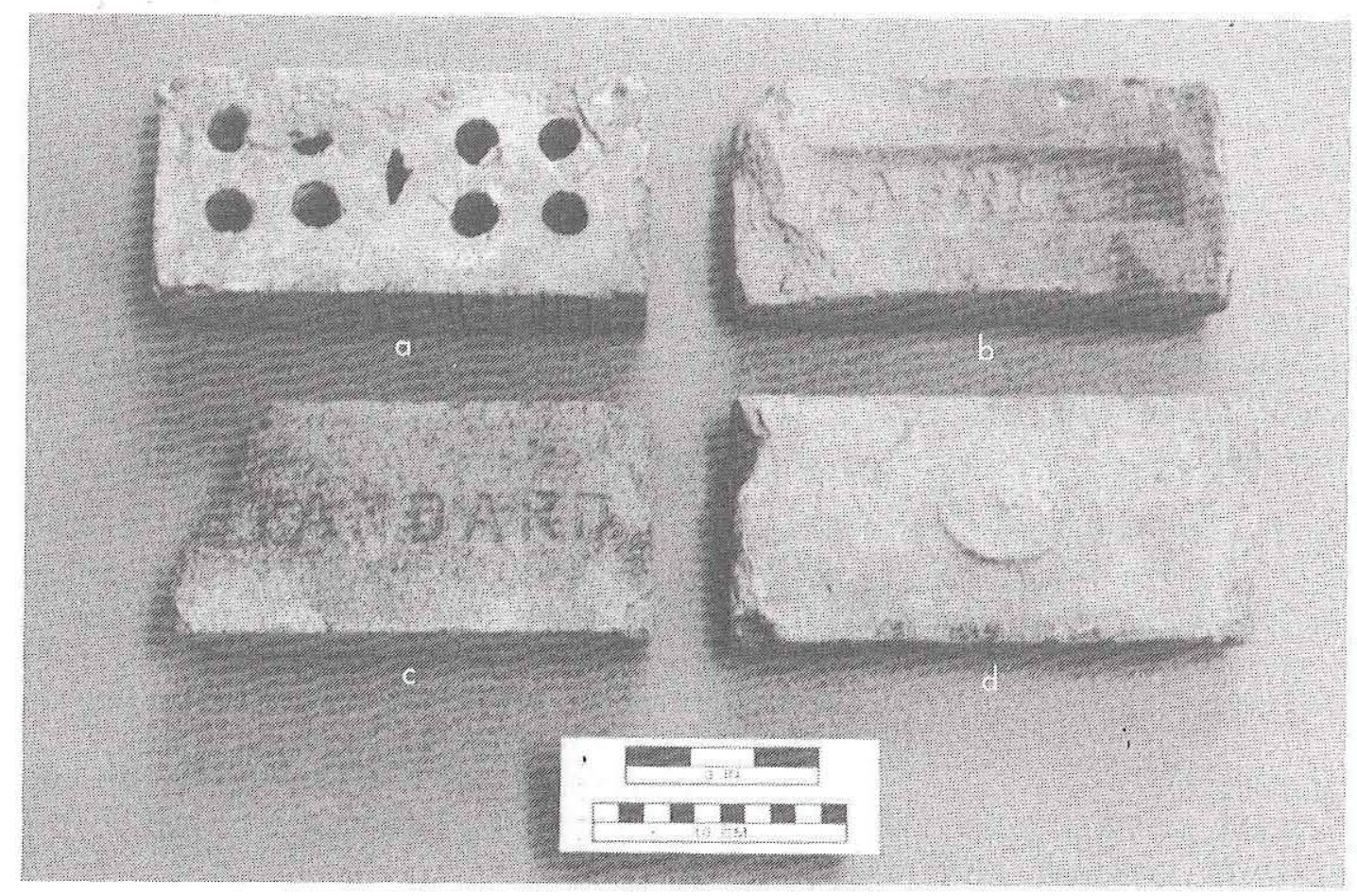

Figure 65. Brick Types 29-32.

\section{Measurements:}

Length: $209 \mathrm{~mm}$

Width: $101 \mathrm{~mm}$

Thickness: $68 \mathrm{~mm}$

Weight: $2,060 \mathrm{~g}$

\section{Matrix Attributes}

Color: Buff

Texture: Fine sandy, slighty porous

Inclusions: Fine mica (?) flecks

Hardness: $3-4$

Manufacturing Process: Soft mud, sand struck

Manufacturing Attributes: Slightly rounded corners/edges; rough struck face

Identifying Markings: None

Other Attributes/Comments: No frog or markings; mud mortar still adhering to collected specimen; Type 6 is very similar to Types 2 and 7 .

\section{Brick Type 7}

Collected Specimens: 1 complete brick from Feature $8 \mathrm{~F}$
Measurements:

Length: $196 \mathrm{~mm}$

Width: $101 \mathrm{~mm}$

Thickness: $57 \mathrm{~mm}$

Weight: $1,823 \mathrm{~g}$

Matrix Attributes:

Color: Buff

Texture: Fine sandy, slightly porous

Inclusions: Fine mica (?) flecks

Hardness: $3-4$

Manufacturing Process: Soft mud, sand struck

Manufacturing Attributes: Slightly to very rounded edges/corners; rough struck face

\section{Identifying Markings: None}

Other Attributes/Comments: Mud mortar adhering to struck face of collected specimen; Type 7 is very similar to Types 2 and 6 .

\section{Brick Type 8}

Collected Specimens: 1 complete brick from Feature $8 \mathrm{G}$ 
Measurements:

Length: $271 \mathrm{~mm}$

Width: $82 \mathrm{~mm}$

Thickness: $51 \mathrm{~mm}$

Weight: $1,827 \mathrm{~g}$

Matrix Attributes:

Color: Buff

Texture: Very fine

Inclusions: None observed

Hardness: $5-6$

Manufacturing Process: Stiff mud

Manufacturing Attributes: Wire cuts on both ends; wire texture on one side; split-face brick with rough-textured side

Identifying Marking No. 1:

Mark: "CESAREO PEREZQUINTANILLA" and "LAD. AGUILA MONTERREY MEXICO." Both are repeated twice in separate lines.

Type: Manufacturer/place name

Letter Height: $8 \mathrm{~mm}$

Description: Very uniform block-style letters enclosed by parallel lines, continuous roller-stamped shallow letters (less than $0.5 \mathrm{~mm}$ deep)

Location: On smooth face

Identifying Marking No. 2:

Mark: "MEXICO-MEXICO-MEXICO" repeated eight times

Type: Country of origin mark

Letter Height: $8 \mathrm{~mm}$

Description: Very uniform block-style letters enclosed by parallel lines, continuous roller-stamped shallow letters (less than $0.5 \mathrm{~mm}$ deep)

Location: On wire-textured side

Other Attributes/Comments: Very well made brick compared to all other Mexican-made bricks from 41HG156. Cesareo Perez Quintanilla is probably a specific brickmaker or the owner of the brickyard. LAD is an abbreviation for ladrillero, or brick factory; hence, the second name translates as the Eagle Brick Factory at Monterrey, Mexico.
Brick Type 9

Collected Specimens: 4 fragments from Feature $8 \mathrm{G}$

Measurements:

Length: $200+\mathrm{mm}$

Width: $95-97 \mathrm{~mm}$

Thickness: $40-43 \mathrm{~mm}$

Matrix Attributes:

Color: Buff

Texture: Fine sandy, porous

Inclusions: None observed

Hardness: 4

Manufacturing Process: Soft mud, sand struck

Manufacturing Attributes: Slightly to very rounded corners/edges; rough-textured struck face with drag lines

Identifying Markings:

Mark: "MEX . . .," "MEXIC . . , , ". . . EXICO," and "WEX . . ." on various fragments. The latter represents an $M$ stamped upside (for Mexico).

Type: Country of origin mark

Letter Height: 12-27 mm

Description: Very crude impressed letters of various sizes and irregular spacing and orientation, average is $3 \mathrm{~mm}$ deep.

Location: On molded face

Other Attributes/Comments: One fragment appears to have had a water-struck (or very wet sandstruck) face.

\section{Brick Type 10A}

Collected Specimens: 1 fragment from Feature $8 \mathrm{G}$

Measurements:

Length: $190+\mathrm{mm}$

Width: $101 \mathrm{~mm}$

Thickness: $62 \mathrm{~mm}$

Matrix Attributes:

Color: Salmon 
Inclusions: Small unidentified pebbles and pebble casts

Hardness: $4-5$

Manufacturing Process: Soft mud, sand struck

Manufacturing Attributes: Slightly rounded corners/edges; split-face brick with rough-textured side; rough struck face with drag lines; rectangular frog (134+ $\mathrm{mm}$ long, $46 \mathrm{~mm}$ wide, and $7 \mathrm{~mm}$ deep) with faceted sides, horizontal on molded face

Identifying Markings:

Mark: "SALINA ..."

Type: Manufacturer name, probably Salinas

Letter Height: $15 \mathrm{~mm}$

Description: Fairly uniform impressed letters, $3 \mathrm{~mm}$ deep

Location: Inside a smaller rectangular depression that is centered inside the frog

Other Attributes/Comments: Type $10 \mathrm{~A}$ is very similar to (and originally was thought to be the same as) Type 10B except that Type 10A has a split face. Type 10A probably represents bricks made at one of the plants owned by Efrain Salinas in Reynosa, Mexico (Dr. Scott Cook, personal communication 1993).

\section{Brick Type 10B}

Collected Specimens: 1 fragment from Feature 8G

\section{Measurements:}

Length: $175+\mathrm{mm}$

Width: $100 \mathrm{~mm}$

Thickness: $64 \mathrm{~mm}$

\section{Matrix Attributes:}

Color: Buff

Texture: Fine sandy, slightly porous

Inclusions: None observed

Hardness: $4-5$

Manufacturing Process: Soft mud, sand struck

Manufacturing Attributes: Slightly rounded comers/ edges (partially damaged); rough struck face; two frogs on molded face; one is large (135+ mm long, $46 \mathrm{~mm}$ wide, $7 \mathrm{~mm}$ deep) horizontal rectangular frog with faceted sides; smaller $(60 \mathrm{~mm}$ long, $26 \mathrm{~mm}$ wide, $4 \mathrm{~mm}$ deep) frog is rectangular with faceted sides but is vertical near one end

Identifying Marking No. 1:

Mark: ". . ALINAS"

Type: Manufacturer name, probably Salinas

Letter Height: $15 \mathrm{~mm}$

Description: Very uniform impressed $(4 \mathrm{~mm}$ deep) letters

Location: Centered in horizontal frog

Identifying Marking No. 2:

Mark: "MEX"

Type: Country of origin mark, Mexico

Letter Height: $15 \mathrm{~mm}$

Description: Very uniform block style impressed (3 $\mathrm{mm}$ deep) letters

Location: In vertical frog

Other Attributes/Comments: Type $10 \mathrm{~B}$ is very similar to (and originally was thought to be the same as) Type 10A except that Type 10B does not have a split face. Type 10B probably represents bricks made at one of the plants owned by Efrain Salinas in Reynosa, Mexico (Dr. Scott Cook, personal communication 1993).

\section{Brick Type 11}

Collected Specimens: 1 nearly complete brick from Feature $8 \mathrm{H}$

Measurements:

Length: $293 \mathrm{~mm}$

Width: $93-95 \mathrm{~mm}$

Thickness: $89 \mathrm{~mm}$

Weight: ca. $3,400 \mathrm{~g}$ (damaged edges)

Matrix Attributes:

Color: Buff

Texture: Fine sandy, slightly porous

Inclusions: None observed

Hardness: $3-4$

Manufacturing Process: Soft mud, sand struck

Manufacturing Attributes: Slightly rounded comers/ angles; split-face brick with rough-textured side; rough struck face; horizontal rectangular $(195 \mathrm{~mm}$ long, $36 \mathrm{~mm}$ wide, 9-10 $\mathrm{mm}$ deep) frog with faceted 
sides

Identifying Markings:

Mark: "MEXICO"

Type: Country of origin mark

Letter Height: $20 \mathrm{~mm}$

Description: Fairly uniform raised letters (2-3 mm high) but very eroded

Location: In frog

\section{Brick Type 12}

Collected Specimens: 1 nearly complete brick from Feature $8 \mathrm{H}$

Measurements:

Length: $209 \mathrm{~mm}$

Width: $96 \mathrm{~mm}$

Thickness: $53 \mathrm{~mm}$

Weight: ca. $1,215 \mathrm{~g}$ (damaged edges)

Matrix Attributes:

Color: Buff

Texture: Very fine

Inclusions: None observed

Hardness: $5-6$

Manufacturing Process: Stiff mud

Manufacturing Attributes: Wire cuts on both faces; wire-texture on one side and both ends; 3 circular holes, 32-mm diameter; sharp corners/edges

Identifying Markings:

Mark: "MEXICO"

Type: Country of origin mark

Letter Height: $8 \mathrm{~mm}$

Description: Very uniform but faint (less than $0.5 \mathrm{~mm}$ deep) impressed block-style letters (may be stamped by a continuous roller mechanism)

Location: Parallel to and between wire cut on one end

\section{Brick Type 13}

Collected Specimens: 1 fragment from Feature $8 \mathrm{H}$

\section{Measurements:}

Length: $185+\mathrm{mm}$

Width: $100 \mathrm{~mm}$
Thickness: $63 \mathrm{~mm}$

Matrix Attributes:

Color: Buff

Texture: Very fine sandy, very porous

Inclusions: Pebble casts noted

Hardness: $3-4$

Manufacturing Process: Soft mud, sand struck

Manufacturing Attributes: Slightly rounded comers and edges; rough struck face; two frogs on molded face: large horizontal rectangular (135 $\mathrm{mm}$ long, $43 \mathrm{~mm}$ wide, $10 \mathrm{~mm}$ deep) frog with faceted sides centered in face; smaller vertical rectangular $(60 \mathrm{~mm}$ long, $24 \mathrm{~mm}$ wide, $4 \mathrm{~mm}$ deep) frog with faceted sides near one end

Identifying Marking No. 1:

Mark: "SALINAS"

Type: Manufacturer name

Letter Height: $15 \mathrm{~mm}$

Description: Very uniform impressed $(3 \mathrm{~mm}$ deep) letters

Location: Centered in horizontal frog

Identifying Marking No. 2:

Mark: "MEX"

Type: Country of origin mark, Mexico

Letter Height: $15 \mathrm{~mm}$

Description: Very uniform impressed $(3 \mathrm{~mm}$ deep) letters

Location: In vertical frog

Other Attributes/Comments: The "SALINAS" and "MEX" name stamps are very similar to those of Types $10 \mathrm{~A}$ and 10B, but the Type 13 horizontal frog is smaller. Type 13 probably represents bricks made at one of the plants owned by Efrain Salinas in Reynosa, Mexico (Dr. Scott Cook, personal communication 1993).

\section{Brick Type 14}

Collected Specimens: 3 fragments from Feature $8 \mathrm{H}$

Measurements:

Length: $160+\mathrm{mm}$

Width: $92-96 \mathrm{~mm}$

Thickness: $37-41 \mathrm{~mm}$ 
Matrix Attributes:

Color: Buff

Texture: Fine sandy, slightly porous

Inclusions: Small unidentified pebbles, small snail shell

Hardness: $3-4$

Manufacturing Process: Soft mud, sand struck

Manufacturing Attributes: Slightly to very rounded corners and edges; rough struck face with drag lines; two frogs on molded face: large horizontal rectangular (170+ mm long, $43 \mathrm{~mm}$ wide, 12-15 $\mathrm{mm}$ deep) frog with faceted sides, centered in face; smaller vertical rectangular ( $70 \mathrm{~mm}$ long, $19 \mathrm{~mm}$ wide, 3-4 mm deep) frog with straight sides, along one end

Identifying Marking No. 1:

Mark: "GOMEZ BRICK"

Type: Manufacturer name

Letter Height: $12 \mathrm{~mm}$

Description: Very uniform but eroded letters, impressed $1 \mathrm{~mm}$ deep inside a 5-mm-deep impressed oval banner

Location: In horizontal frog

Identifying Marking No. 2:

Mark: "MEXICO"

Type: Country of origin mark

Letter Height: $12 \mathrm{~mm}$

Description: Very uniform but very eroded letters, impressed 1-2 mm deep

Location: In vertical frog

Other Attributes/Comments: Type 14 probably represents bricks made at the brick plant owned by Alberto Gomez in Reynosa, Mexico (Dr. Scott Cook, personal communication 1993).

\section{Brick Type 15}

Collected Specimens: 1 fragment from Feature 8H

Measurements:

Length: $130+\mathrm{mm}$

Width: $88-89 \mathrm{~mm}$

Thickness: $47-49 \mathrm{~mm}$

Matrix Attributes:

Color: Salmon

Texture: Fine sandy, slightly porous
Inclusions: Unidentified pebbles and caliche fragments

Hardness: $3-4$

Manufacturing Process: Soft mud, sand struck

Manufacturing Attributes: Slightly to very rounded corners and edges; split-face brick with roughtextured side; rough struck face with drag lines; two frogs on molded face; horizontal rectangular $(55+\mathrm{mm}$ long, 34-36 mm wide, 7-9 mm thick) frog with straight sides, off-center in face; vertical shieldshaped (60 mm high, $54 \mathrm{~mm}$ wide, and $3 \mathrm{~mm}$ deep) frog near one end

Identifying Marking No. 1:

Mark: "ME ..."

Type: Country of origin mark, Mexico

Letter Height: 24-25 mm

Description: Irregular raised letters $(2 \mathrm{~mm}$ high), may have been burned into the kick plate

Location: In horizontal frog

Identifying Marking No. 2:

Mark: "LA MAR"

Type: Probably a manufacturer or product name Letter Height: $15 \mathrm{~mm}$

Description: Very uniform block-style impressed letters ( $3 \mathrm{~mm}$ deep)

Location: Centered in the vertical frog with round impressed circles in the top and bottom apexes of the shield

Other Attributes/Comments: The horizontal frog is skewed $8^{\circ}-10^{\circ}$ off horizontal, and the MEXICO name is upside down relative to the LA MAR shield.

\section{Brick Type 16}

Collected Specimens: 1 fragment from Feature $8 \mathrm{H}$

Measurements:

Length: $174+\mathrm{mm}$

Width: $95-98 \mathrm{~mm}$

Thickness: $57-59 \mathrm{~mm}$

Matrix Attributes:

Color: Buff

Texture: Fine sandy, porous

Inclusions: Angular clay or grog (old brick ?) 
fragments

Hardness: 4-5

Manufacturing Process: Soft mud, sand struck

Manufacturing Attributes: Slightly to very rounded comers and edges; rough struck face with drag lines; one horizontal rectangular (143+ mm long, $57 \mathrm{~mm}$ wide, 6-8 $\mathrm{mm}$ deep) frog with faceted sides on molded face

\section{Identifying Markings:}

Mark: "MEXICO"

Type: Country of origin mark

Letter Height: $31-32 \mathrm{~mm}$

Description: Very irregular impressed letters (2 mm deep) of slightly different sizes; name may have been stamped after molding

Location: Centered in horizontal frog

Brick Type 17

Collected Specimens: 2 fragments from Feature $8 \mathrm{H}$

\section{Measurements:}

Length: $260+\mathrm{mm}$

Width: $99-100 \mathrm{~mm}$

Thickness: $59-63 \mathrm{~mm}$

\section{Matrix Attributes:}

Color: Buff

Texture: Fine sandy, porous

Inclusions: Unidentified angular rock or grog fragments, snail shell fragment

Hardness: $3-4$

Manufacturing Process: Soft mud, sand struck

Manufacturing Attributes: Slightly to very rounded comers and edges; rough struck face with drag lines; two frogs on molded face: larger horizontal rectangular frog (205 $\mathrm{mm}$ estimated length, 35$39 \mathrm{~mm}$ wide, 13-15 mm deep) centered in face; smaller vertical rectangular frog (77 mm long, $19 \mathrm{~mm}$ wide, 3-4 $\mathrm{mm}$ deep) along one end

\section{Identifying Marking No. 1:}

Mark: "RIO-BRAVO"

Type: Probably a manufacturer or product name Letter Height: $22 \mathrm{~mm}$

Description: Very uniform impressed letters, unusually deep ( $5 \mathrm{~mm})$

Location: Centered in horizontal frog

Identifying Marking No. 2:

Mark: "MEXICO"

Type: Country of origin name

Letter Height: $12 \mathrm{~mm}$

Description: Very uniform impressed letters (3 $\mathrm{mm}$ deep)

Location: Centered in vertical frog

Other Attributes/Comments: Raised bumps (2-5 mm high) on each end facet of the horizontal frog may be from screw/nail holes for attaching the kick to the bottom of the mold.

Brick Type 18

Collected Specimens: 1 fragment from Feature $8 \mathrm{H}$

\section{Measurements:}

Length: $198+\mathrm{mm}$

Width: $92 \mathrm{~mm}$

Thickness: $67 \mathrm{~mm}$

\section{Matrix Attributes:}

Color: Buff

Texture: Medium sandy, porous

Inclusions: Abundant unidentified angular and rounded fragments

Hardness: $3-4$

Manufacturing Process: Soft mud, sand struck

Manufacturing Attributes: Slightly to very rounded corners and edges; split-face brick with roughtextured side; rough struck face; one horizontal rectangular frog $(142+\mathrm{mm}$ long, $37-38 \mathrm{~mm}$ wide, 7$8 \mathrm{~mm}$ deep) with straight sides, centered in molded face

Identifying Markings:

Mark: "OLI-Y . . ." Backwards L and Y indicate that it is a reverse image

Type: Probably a manufacturer, place, or product name; corrected name would be ". . . Y-ILO"

Letter Height: $28-29 \mathrm{~mm}$

Description: Very irregular angular impressed letters, unusually deep (6-7 mm)

Location: Centered in horizontal frog 
Other Attributes/Comments: Struck face has some ripples indicating that it may have been water struck (or very wet sand struck). This brick probably was made in Mexico.

\section{Brick Type 19}

Collected Specimens: 1 fragment from Feature $8 \mathrm{H}$

\section{Measurements:}

Length: $185+\mathrm{mm}$

Width: $100 \mathrm{~mm}$

Thickness: $59-60 \mathrm{~mm}$

\section{Matrix Attributes:}

Color: Buff

Texture: Fine sandy, slightly porous

Inclusions: Few unidentified angular fragments

Hardness: $3-4$

Manufacturing Process: Soft mud; sand struck

Manufacturing Attributes: Slightly to very rounded corners and edges; rough struck face; two frogs on molded face: large horizontal rectangular frog (131 mm long, 44-45 $\mathrm{mm}$ wide, $15 \mathrm{~mm}$ deep) with faceted sides, centered in face; smaller vertical rectangular frog ( $47+\mathrm{mm}$ long, $17 \mathrm{~mm}+$ wide, $3 \mathrm{~mm}$ deep) with faceted sides, along one end of face; very incomplete

\section{Identifying Markings:}

Mark: "M . . ."

Type: Probably a country of origin mark, Mexico

Letter Height: $12 \mathrm{~mm}$

Description: Impressed letters (2-3 mm deep), too incomplete for further description

Location: In vertical frog

Other Attributes/Comments: No marking in horizontal frog.

\section{Brick Type 20}

Collected Specimens: 1 fragment from Feature $8 \mathrm{H}$

\section{Measurements:}

Length: $190+\mathrm{mm}$

Width: $93-94 \mathrm{~mm}$

Thickness: $60-62 \mathrm{~mm}$

\section{Matrix Attributes:}

Color: Buff

Texture: Fine sandy, slightly porous

Inclusions: Few unidentified angular and rounded fragments

Hardness: 3-4

Manufacturing Process: Soft mud, sand struck

Manufacturing Attributes: Very rounded corners and edges; rough struck face; two frogs on molded face: large horizontal rectangular frog $(135+\mathrm{mm}$ long, $57 \mathrm{~mm}$ wide, 9-12 $\mathrm{mm}$ deep) with faceted sides, centered in face; smaller vertical long oval frog (55+ $\mathrm{mm}$ long, $13 \mathrm{~mm}$ wide, 2-3 $\mathrm{mm}$ deep) with straight sides, along one end of face

Identifying Markings:

Mark: ". . EXIC'"

Type: Country of origin mark, Mexico

Letter Height: $10 \mathrm{~mm}$

Description: Fairly uniform but very eroded impressed letters (1-2 mm deep)

Location: In vertical frog

Other Attributes/Comments: No markings in horizontal frog. Vertical frog has small raised $(1 \mathrm{~mm}$ high) arc on one end that may be from screw/nail hole to attach the kick to the bottom of the mold.

\section{Brick Type 21}

Collected Specimens: 1 fragment from Feature $8 \mathrm{H}$

Measurements:

Length: $85+\mathrm{mm}$

Width: $96 \mathrm{~mm}$

Thickness: $40-45 \mathrm{~mm}$

Matrix Attributes:

Color: Salmon

Texture: Fine sandy, irregular porosity Inclusions: Abundant small angular calcareous (?) fragments, 1 large $(13 \mathrm{~mm})$ caliche pebble

Hardness: $3-4$

Manufacturing Process: Soft mud, sand struck

Manufacturing Attributes: Slightly to very rounded corners and edges; rough struck face; one horizontal 
rectanguiar frog $(34+\mathrm{mm}$ long, $25 \mathrm{~mm}$ wide, $3 \mathrm{~mm}$ deep) with faceted sides, centered in molded face

\section{Identifying Markings:}

Mark: "SA ..."

Type: Manufacturer or place name, probably Salinas, Mexico

Letter Height: $14 \mathrm{~mm}$

Description: Very uniform block-style impressed letters (3-4 $\mathrm{mm}$ deep)

Location: Centered in frog

Other Attributes/Comments: Type 21 probably represents bricks made at one of the brick plants owned by Efrain Salinas in Reynosa, Mexico (Dr. Scott Cook, personal communication 1993).

\section{Brick Type 22}

Collected Specimens: 1 fragment from Feature $8 \mathrm{H}$

\section{Measurements:}

Length: $147+\mathrm{mm}$

Width: $98 \mathrm{~mm}$

Thickness: $57 \mathrm{~mm}$

\section{Matrix Attributes:}

Color: Buff

Texture: Fine sandy, porous

Inclusions: Abundant angular clay (?) fragments

Hardness: $3-4$

Manufacturing Process: Soft mud, sand struck

Manufacturing Attributes: Slightly to very rounded corners and edges; rough struck face; one horizontal rectangular frog (105+ $\mathrm{mm}$ long, $35 \mathrm{~mm}$ wide, $8 \mathrm{~mm}$ deep) with faceted sides, centered in molded face

\section{Identifying Markings:}

Mark: ". . XICO"

Type: Country of origin mark, Mexico

Letter Height: $14-25 \mathrm{~mm}$

Description: Very irregular impressed letters (2 $\mathrm{mm}$ deep) of various sizes

Location: In frog

\section{Brick Type 23}

Collected Specimens: 1 nearly complete fragment from Feature $8 \mathrm{H}$
Measurements:

Length: $199 \mathrm{~mm}$

Width: $93+\mathrm{mm}$

Thickness: $55 \mathrm{~mm}$

Weight: ca. $1,536 \mathrm{~g}$

Matrix Attributes:

Color: Salmon

Texture: Very fine

Inclusions: Few pebble casts and fine mica flecks

Hardness: 4

Manufacturing Process: Stiff mud

Manufacturing Attributes: Wire cuts (arc-shaped) on both faces; wire texture on one side and both faces (may have been on other side as well); sharp comers and edges

\section{Identifying Markings:}

Mark: "MEXICO"

Type: Country of origin mark

Letter Height: $7 \mathrm{~mm}$

Description: Very uniform but faint impressed letters (less than $1 \mathrm{~mm}$ deep), probably produced by continuous roller stamp

Location: Perpendicular on one end, parallel to and between wire-texture lines

Other Attributes/Comments: One side has been chipped (apparently intentionally) to produce a rough-textured surface. This brick has wire texturing and stamped name that is very similar to that of Type 12 , but the Type 23 brick has no perforations.

\section{Brick Type 24}

Collected Specimens: 2 nearly complete fragments with some edge damage: 1 from Feature $8 \mathrm{H}, 1$ from Feature 13

\section{Measurements:}

Length: $210 \mathrm{~mm}$

Width: $102-106 \mathrm{~mm}$

Thickness: $63-67 \mathrm{~mm}$

Weight: $1,916-2,125 \mathrm{~g}$

\section{Matrix Attributes:}

Color: Grade from buff to salmon

Texture: Fine to medium sandy, low porosity 
Inclusions: None observed

Hardness: Less than 3

Manufacturing Process: Soft mud, sand struck

Manufacturing Attributes: Very rounded corners and edges; rough struck face

Identifying Markings:

Mark: "EL"

Type: Probable cattle brand

Letter Height: $40-45 \mathrm{~mm}$

Description: Irregular and very eroded raised letters $(0-2 \mathrm{~mm}$ high)

Location: Oriented vertically in the center of the molded face

\section{Brick Type 25}

Collected Specimens: 1 fragment (very incomplete) from Feature 10

\section{Measurements:}

Length: $190+\mathrm{mm}$

Width: $88+\mathrm{mm}$

Thickness: $49 \mathrm{~mm}$

\section{Matrix Attributes:}

Color: Salmon

Texture: Very fine, laminated

Inclusions: Few angular clay or grog fragments

Hardness: 4

\section{Manufacturing Process: Stiff mud}

Manufacturing Attributes: Wire cut (horizontal) on one face; opposite face probably had wire cut, but it is smoothed and obliterated (by conveyor belt ?); sharp corners and edges

Identifying Markings:

Mark: ". . XICO ME ..."

Type: Country of origin mark

Letter Height: $20 \mathrm{~mm}$

Description: Very uniform, thin-lined impressed letters (less than $1 \mathrm{~mm}$ deep), probably made by continuous roller stamp

Location: Horizontal on smooth side

\section{Brick Type 26}

Collected Specimens: 2 fragments from Feature 10
Measurements:

Length: $190+\mathrm{mm}(280-285 \mathrm{~mm}$ estimated)

Width: $80-89 \mathrm{~mm}$

Thickness: $56-60 \mathrm{~mm}$

Matrix Attributes:

Color: Buff

Texture: Fine sandy, very porous

Inclusions: Few angular clay or grog fragments and fine mica flecks

Hardness: $3-4$

Manufacturing Process: Soft mud, sand struck

Manufacturing Attributes: Slightly to very rounded corners and edges; rough struck face; split-face brick with rough-textured side; one horizontal rectangular frog (143+ mm long, $43-45 \mathrm{~mm}$ wide, $10 \mathrm{~mm}$ deep) with faceted sides, centered in molded face

\section{Identifying Markings:}

Mark: ". . XICO" and "WEX ..." (latter is upside down M for MEXICO)

Type: Country of origin mark

Letter Height: $21-28 \mathrm{~mm}$

Description: Very irregular impressed letters (2-3 mm deep) of various sizes

Location: Poorly centered in frog

Other Attributes/Comments: These two fragments are very similar but differences in the letters indicate that they were made in different molds or that the name stamp was done after molding.

\section{Brick Type 27}

Collected Specimens: 1 fragment from Feature 10

Measurements:

Length: $176+\mathrm{mm}$

Width: $195 \mathrm{~mm}$

Thickness: $55 \mathrm{~mm}$

Matrix Attributes:

Color: Buff

Texture: Fine sandy, very porous

Inclusions: Few calcareous (?) pebbles

Hardness: 3-4

Manufacturing Process: Soft mud, sand struck 
Manufacturing Attributes: Slightly to very rounded comers and edges; split-face brick with roughtextured side; rough struck face; one horizontal rectangular frog $(110+\mathrm{mm}$ long, 33-34 $\mathrm{mm}$ wide, $6 \mathrm{~mm}$ deep) with faceted sides, centered in molded face

Identifying Markings:

Mark: ". . EXICO"

Type: Country of origin mark

Letter Height: $18 \mathrm{~mm}$

Description: Very uniform but slightly eroded raised letters (2-3 $\mathrm{mm}$ high)

Location: Centered in frog

\section{Brick Type 28}

Collected Specimens: 1 fragment from Feature 12

\section{Measurements:}

Length: $253+\mathrm{mm}$

Width: 94-95 mm

Thickness: $65 \mathrm{~mm}$

\section{Matrix Attributes:}

Color: Buff

Texture: Fine sandy, slightly porous

Inclusions: Few calcareous (?) pebbles

Hardness: $3-4$

Manufacturing Process: Soft mud, sand struck

Manufacturing Attributes: Rounded comers and edges; rough struck face; two frogs on molded face: larger horizontal rectangular frog (158+ mm long, 33$34 \mathrm{~mm}$ wide, $18 \mathrm{~mm}$ deep) with faceted sides, centered in face; smaller vertical rectangular frog (49 $\mathrm{mm}$ long, $20 \mathrm{~mm}$ wide, 5-6 $\mathrm{mm}$ deep) with faceted sides, along one end of face

\section{Identifying Marking No. 1}

Mark: "SO. WEST"

Type: Manufacturer or product name

Letter Height: $15 \mathrm{~mm}$

Description: Very uniform impressed letters (2-3 mm deep)

Location: Centered in horizontal frog

\section{Identifying Marking No. 2}

Mark: "MEX."

Type: Country of origin name
Letter Height: $13 \mathrm{~mm}$

Description: Very uniform but eroded impressed letters (2-3 mm deep)

Location: Centered in vertical frog

Other Attributes/Comments: Struck face has some ripples indicating that it may have been water struck (or very wet sand struck).

\section{Brick Type 29}

Collected Specimens: 1 complete brick from Feature 12

Measurements:

Length: $209 \mathrm{~mm}$

Width: $101 \mathrm{~mm}$

Thickness: $59 \mathrm{~mm}$

Weight: $1,878 \mathrm{~g}$

Matrix Attributes:

Color: Very pale brown (10YR 7/4)

Texture: Very fine clay

Inclusions: None observed

Hardness: $7-8$

Manufacturing Process: Stiff mud

Manufacturing Attributes: Wire cuts (arc-shaped) on both faces; wire texture on one side only; 1 pointed oval perforation $(25 \times 10 \mathrm{~mm})$ in center and 4 circular perforations ( $20 \mathrm{~mm}$ diameter) on each side

Other Attributes/Comments: Concrete mortar is present in perforations.

\section{Brick Type 30}

Collected Specimens: 1 nearly complete brick from Feature 12 (has damaged edges)

\section{Measurements:}

Length: $213-214 \mathrm{~mm}$

Width: $100 \mathrm{~mm}$

Thickness: $53-54 \mathrm{~mm}$

Weight: $1,554 \mathrm{~g}$

\section{Matrix Attributes:}

Color: Salmon

Texture: Very fine sandy, slightly porous Inclusions: Fine flecks of mica 
Width: $100 \mathrm{~mm}$

Thickness: $53-54 \mathrm{~mm}$

Weight: $1,554 \mathrm{~g}$

Matrix Attributes:

Color: Salmon

Texture: Very fine sandy, slightly porous

Inclusions: Fine flecks of mica

Hardness: $3-4$

Manufacturing Process: Soft mud, sand struck

Manufacturing Attributes: Rounded to very rounded comers and edges; rough struck face; one horizontal rectangular frog (160 $\mathrm{mm}$ long, 34-35 mm wide, 7-8 $\mathrm{mm}$ deep) with faceted sides, centered in molded face

Identifying Markings:

Mark: "MEXICO"

Type: Country of origin mark

Letter Height: $13-21 \mathrm{~mm}$

Description: Very irregular impressed letters (1-2 mm deep) of various sizes, irregular spacing

Location: Centered in frog

Other Attributes/Comments: Has remnants of white lime mortar or plaster.

\section{Brick Type 31}

Collected Specimens: 1 fragment from Feature 13

\section{Measurements:}

Length: $225+\mathrm{mm}$

Width: $97 \mathrm{~mm}$

Thickness: $58 \mathrm{~mm}$

\section{Matrix Attributes:}

Color: Yellowish red (5YR 5/6)

Texture: Very fine clay with fine to coarse inclusions, no pores

Inclusions: Abundant yellowish or reddish angular fragments of all sizes

Hardness: 6-7

Manufacturing Process: Dry pressed

Manufacturing Attributes: All faces, sides, and ends are smooth; very sharp corners and edges
Identifying Markings:

Mark: "STANDARD"

Type: Manufacturer name

Letter Height: $20 \mathrm{~mm}$

Description: Very uniform neatly impressed letters (1 mm deep)

Location: Centered on one face, horizontal

Identification: This brick is identical to one illustrated by Steinbomer (1980:photo \#243). It was made by the Standard Brick Company of Palmer, Texas (Ellis County).

\section{Brick Type 32}

Collected Specimens: 1 complete brick (with slightly damaged edges) from Feature 12

Measurements:

Length: $219 \mathrm{~mm}$

Width: $102 \mathrm{~mm}$

Thickness: $49-53 \mathrm{~mm}$

Weight: $1,787 \mathrm{~g}$

Matrix Attributes:

Color: Salmon

Texture: Fine sandy, slightly porous

Inclusions: Fine flecks of mica

Hardness: 3-4

Manufacturing Process: Soft mud, sand struck

Manufacturing Attributes: Rounded to very rounded corners and edges; rough struck face

Identifying Markings:

Mark: A crescent and star design

Type: Probably a cattle brand mark

Design Height: $58 \mathrm{~mm}$

Description: Fairly uniform but very eroded raised design ( $0-3 \mathrm{~mm}$ high)

Location: Oriented vertically in the center of the molded face

Other Attributes/Comments: Collected specimen is slightly warped. Struck face is mostly covered with mud mortar.

\section{Discussion and Summary}

The features that yielded the bricks described 
a broader context, they are important for understanding the history of the community of El Capote. The entire community was virtually abandoned after World War II when the land was cleared for farming, and these dumps probably represent structural debris derived from nearby houses that were torn down within the last 30-50 years. The wide range of variability represented in these bricks may be indicative of the range of different construction materials used in houses in and around El Capote. These bricks also indicate a wide range of different manufacturing sources, and interestingly, they indicate that many of the types are imported Mexican-made bricks (Table 28).

Stamping of bricks with "Mexico" is a very late nineteenth- and twentieth-century phenomena. The 1891 McKinley Tariff Act required that items imported into the United States be marked with their country of origin. It is not clear if Mexican manufacturers immediately began to mark their bricks of if some subsequent customs regulation specifically implemented the marking of bricks with their country or origin. It is not likely, however, that bricks manufactured in Mexico prior to the 1891 mandate would have been marked regularly. The country of origin identification marking is not a particularly sensitive time indicator because it has been used throughout the twentieth century and is still required today. In fact, large quantities of hand-molded, soft-mud, Mexican-made bricks were being imported into the United States as late as 1980 (Steinbomer 1981:
46-47) and are still being imported today. Unfortunately, not much is known about the brick industry in Mexico, but research focused on brickmaking in the Lower Rio Grande Valley of Texas and Mexico currently is being conducted by Dr. Scott Cook (Department of Anthropology, University of Connecticut) and Dr. Joseph Spielberg (Department of Anthropology, Michigan State University).

Along with the country of origin, the places where the bricks were manufactured (i.e., the location of the brickyard) and the manufacturer and/or product names often are identified. For example, one specimen (Type 8) is marked as having been manufactured at the Eagle Brick Plant of Monterrey, Mexico, while the "STANDARD" name identifies another (Type 31) as being made by the Standard Brick Company. The "ELGIN STD SANI-FINISH" name on another specimen (Type 5) identifies both the manufacturer and the specific product (i.e., the trade name of a particular type of brick). The "SALINAS" (Types 10, 13, and 21) name apparently refers to bricks made in Reynosa, Mexico, at one or more of various plants owned by Efrain Salinas, while "GOMEZ BRICK" (Type 14) was made at a Reynosa plant owned by Alberto Gomez (Dr. Scott Cook, personal communciation 1993). In many cases, however, it is unclear exactly what the name means. For example, the names "LA MAR" (Type 15), "RIOBRAVO" (Type 17), and "SO. WEST" (Type 28) could refer to manufacturer, place, and/or product names. They most likely refer to specific

TABLE 28

MANUFACTURING PROCESSES AND SOURCES OF BRICK TYPES 4-32

\begin{tabular}{|l|l|l|c|c|c|c|}
\hline $\begin{array}{l}\text { Manufacturing } \\
\text { Technique }\end{array}$ & Mexican Made & $\begin{array}{l}\text { Probably } \\
\text { Mexican Made }\end{array}$ & U.S. Made & $\begin{array}{l}\text { Probably } \\
\text { U.S. Made }\end{array}$ & Unknown & Totals \\
\hline Soft mud & $\begin{array}{l}9,10 \mathrm{~B}, 11,13,14,15,16, \\
17,20,22,26,27,28,30\end{array}$ & $10 \mathrm{~A}, 18,19,21$ & - & $24^{*}, 32^{*}$ & 6,7 & 22 \\
\hline Stiff mud & $8,12,23,25$ & - & - & 4 & 29 & 6 \\
\hline Dry pressed & - & - & $5 * *, 31^{* * * *}$ & - & - & 2 \\
\hline Totals & 18 & 4 & 2 & 3 & 3 & 30 \\
\hline $\begin{array}{l}* \text { *Marked with a probable cattle brand } \\
\text { **Made in Texas by one of the Elgin brick companies } \\
\text { ***Made in Ellis County, Texas, by the Standard Brick Company }\end{array}$ & \\
\hline
\end{tabular}


manufacturing plants or brickyards, but these markings have not been identified positively.

An unusual aspect of "Mexican" bricks is that they were not necessarily fired in Mexico. A Mexican stamp definitely indicates that they were molded in Mexico, but according to Scott Cook (personal communication 1993), in the latter half of the twentieth century it became a fairly common practice to mold and dry bricks in Mexico and then take them across the river to be fired in Texas. While the exact impetus for this manufacturing strategy is not fully understood, Cook suggested that it probably was related to changes in the cost and/or availability of Mexican labor in Texas following the implementation of new immigration laws after World War II.
Also of interest in the $41 \mathrm{HG} 156$ brick sample are two types with distinctive "cattle brand marks" (Figure 66). Most of these simple markings are registered livestock brands, the images of which were burned into the bottom of a brick mold to create a raised mark on a brick's molded face. The use of such marks to identify bricks made at or for a particular ranch apparently was a fairly common practice in Texas and in the Lower Rio Grande Valley (Robert Steinbomer, personal communication 1993). Not all raised markings actually represent cattle brands, however, and the "EL" and the crescent/star marks found on Types 24 and 32, respectively, have not been identified. They may have been cattle brands used by some nearby ranch, but they were not found among the registered brands for Hidalgo County.

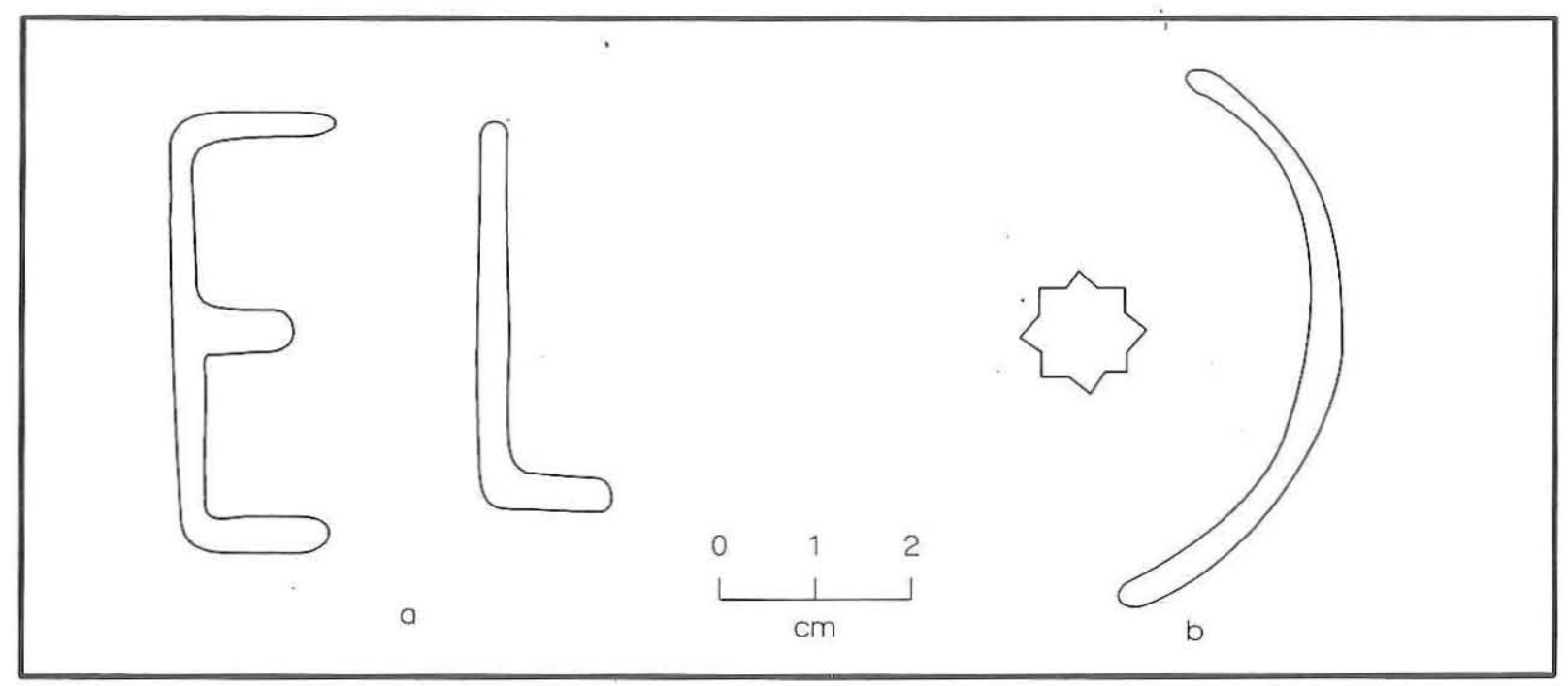

Figure 66. Possible cattle brand marks on bricks from 41HG156. (a) Type 24 mark; (b) Type 32 mark.

\section{REFERENCES CITED}

Gurcke, Karl

1987 Bricks and Brickmaking: A Handbook for Historical Archaeology. University of Idaho Press, Moscow.

Steinbomer, Robert A.

1980 Brickmaking in Texas: A History of the
Industry and Its Products. Unpublished ms. submitted to the Texas Architectural Foundation.

1981 The Texas Brick: A Brief History of the Industry and Its Product. Texás Architect (January/February). 


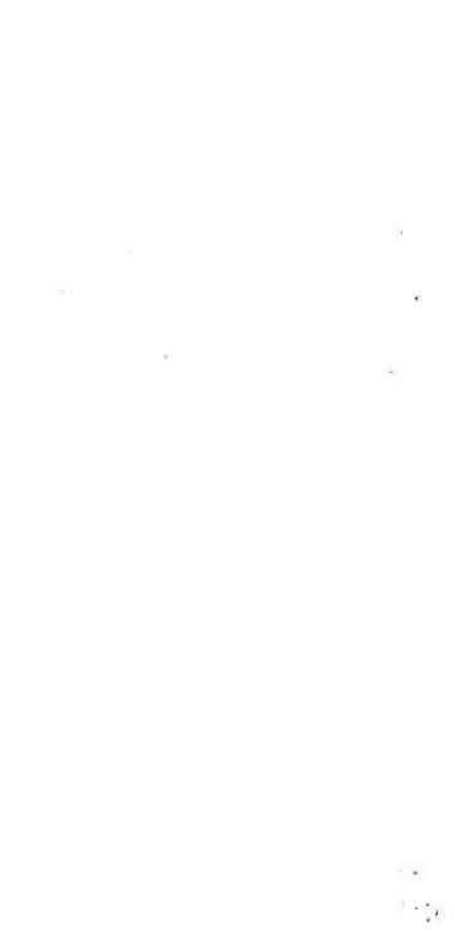


